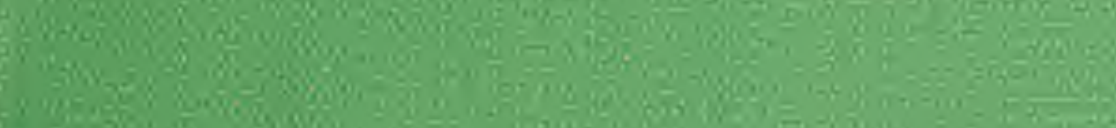

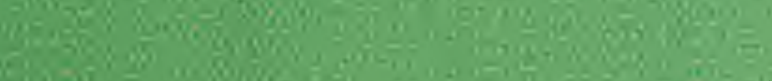

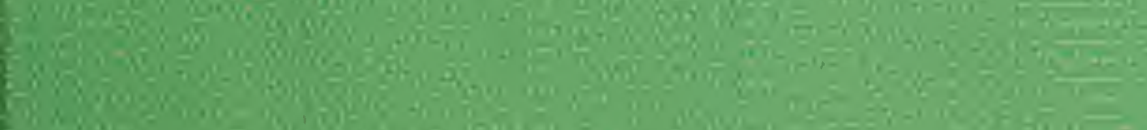

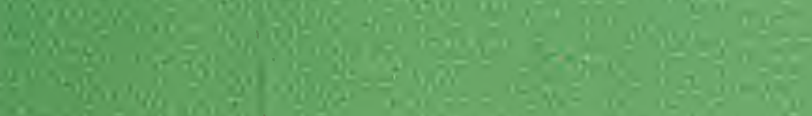

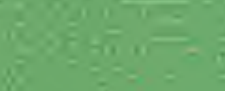
$2-190$.

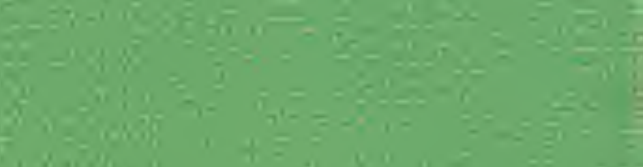

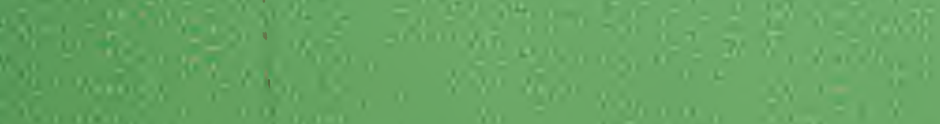

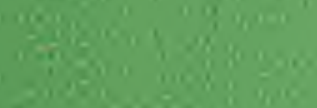

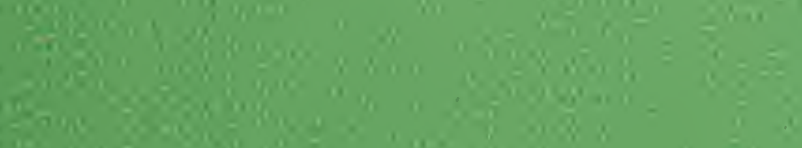

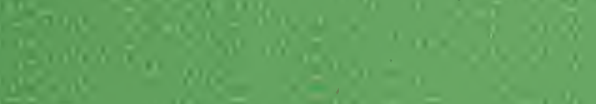

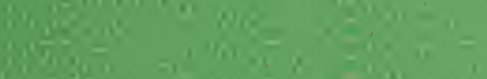

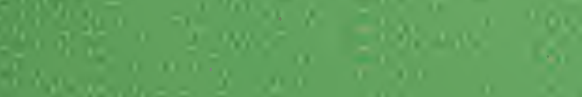

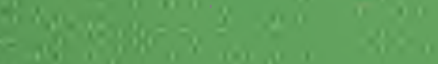

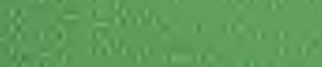

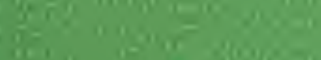

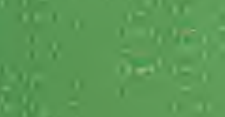

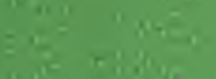

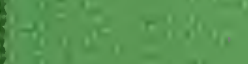

$=\frac{3}{20}$

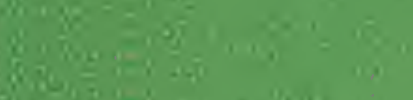

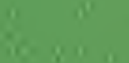

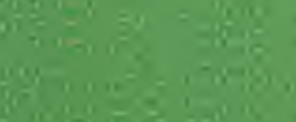

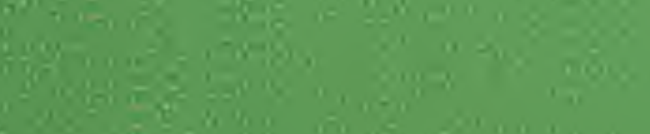

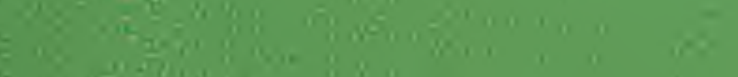

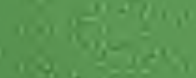

$y_{0,0}$

$x_{0}$

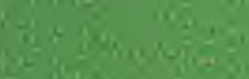

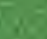

$\rightarrow x_{0}=7 x_{1}=0$

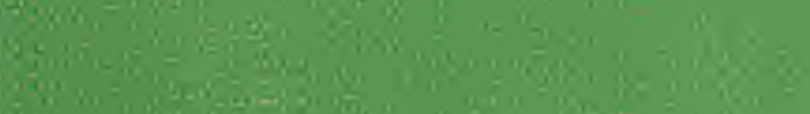

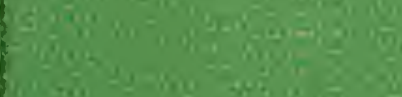

roger,

$y_{1}^{\infty}$

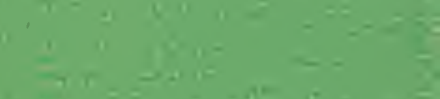

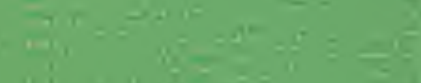




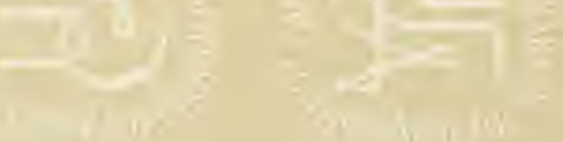

$$
\begin{aligned}
& 1 \frac{4}{2}= \\
& (\sqrt{x}=(5 \sqrt{x}) \\
& \text { WP }=y_{p} \\
& \text {-19t |l| in ing } \\
& \begin{array}{l}
3020 \\
= \\
=
\end{array}
\end{aligned}
$$

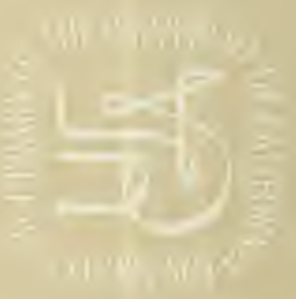

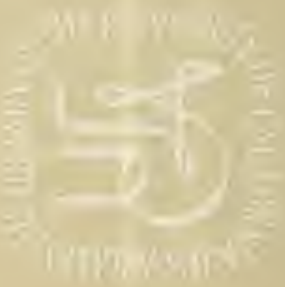

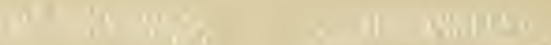

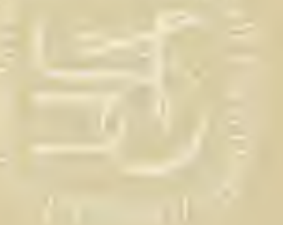

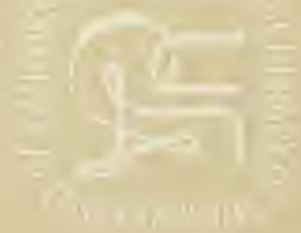

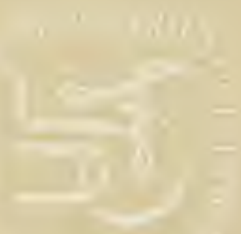

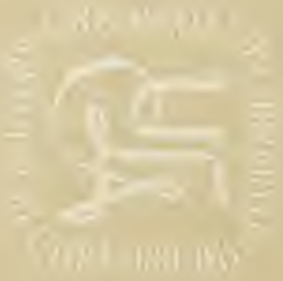

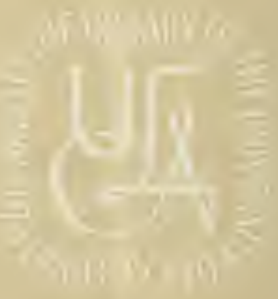

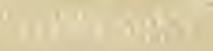

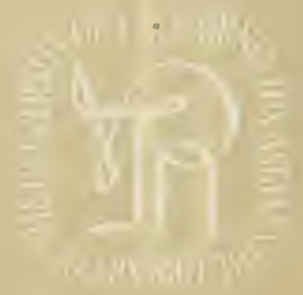


Digitized by the Internet Archive in 2008 with funding from Microsoft Corporation 


SEA AND LAND 




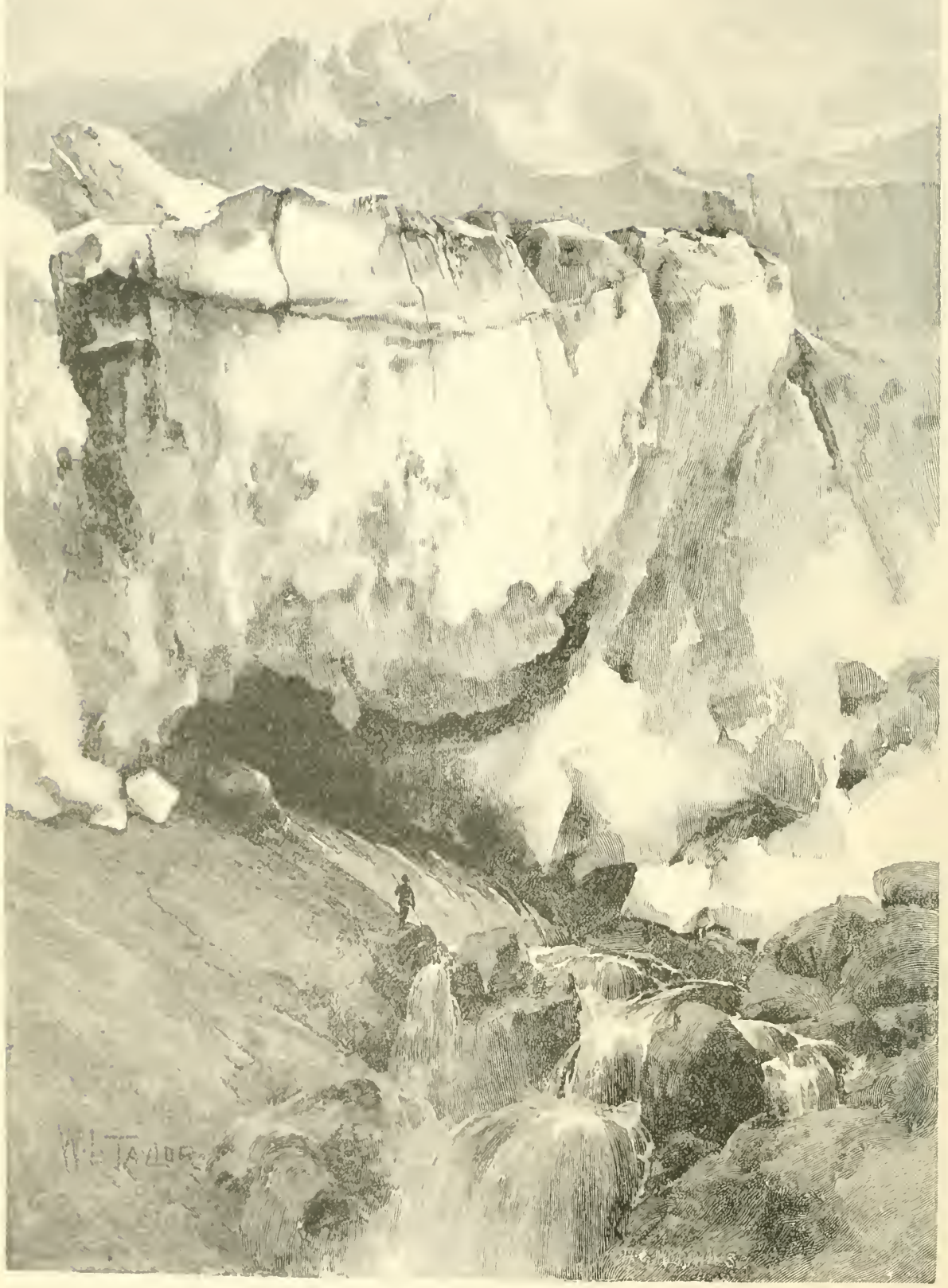

View of the Extremity of a Greenland Glacier

Showing the ice cave from which emerges a sub-glacial river. The peaks in the background are composed of ice much tissured by the irregularities of the surface over which it is moving. 




\section{SEA AND LAND}

FEATURES OF COASTS AND OCEANS WITH SPECIAI REFERENCE TO THE LIFE OF MAN

N. S. SHALER

NEW YORK

CHARLES SCRIBNER'S SONS ${ }_{1} S_{9+}$ 
CiPIRIG,HT, TO 4, BY

CHARLES SCRIFAER'S TONS

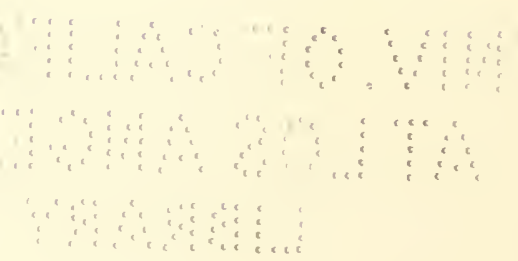

Press of J. J. Little \& Co Astor Place, New York 


\section{PREFACE}

THE object of this book is to introduce unprofessional students of nature to certain interesting phenomena of the sea-shore and of the depths of the occan. In no other fields are large and important truths which are distinctly related to human interests so readily to be traced; yet the treatises which deal with these matters are few in number, and generally of a recondite character.

The aim of the writer in preparing the essays which are here presented has been to separate from the great body of technical knowledge concerning shores and seas those features which have value for the reason that they may serve to enlarge the reader's conception as to the methods of nature. As commonly observed, or as learned from textbooks, these truths appear to be fragmentary and lead to no extended notions as to the workings of the earth's machinery: thus the student is not led to form those conceptions which it is most important that he should gain.

In part the matter presented in the following pages has been printed in Scribner's Magazine. That especially relatinn to harbors, which is contained in the three last chapters, is mainly extracted from a report on the Geological History of Harbors, which was printed in the Thirtecnth Annual Report of the Director of the United States Creolosical Survey. The author and publisher are alike indebted to that Survey for permission to use the text and the plates which appear in this part of the book.

$$
\text { \$.8. }
$$





\section{CONTENTS}

\section{SEA AND LAND}

How Energy Comes to and Acts upon the Earth's surface. - The Work of Water on the Coasts. - Facts to be Noted on a Coast-1ine. - Iand constantly. Nlearing away and Sea-Floor Receiring fediments. - Slight Effect of sea on kocky shore. - Effect of Shore Currents.-Trap-Dykes. - The Great Vorkshire Wave-lerrace.Sea-Caves. - Frost and Ice._Organic Life._Elevated and submerged lieacher..

\section{SEA-BEACHES}

Various Divisions of Shore-Line.-Symmetry of Sea-Beaches.-Action of Surf.-Kate of Wear of Detritus. - Action of Coast Current..-Sand Dunes.-l'ocket-lieaches. -Action of Sea-Weeds. - Straight leaches-Continental She.lf. - Iction of Tiles and Waves. - Variations in Level of Shores. - Formation of Lagoons. - Marive Marshes: their Agricultural Value.-Endurance of Sand: Effect in I'rotecting

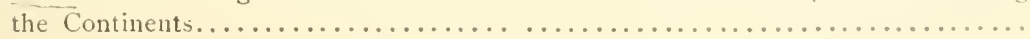

\section{THE DEPTHS OF THE SEA}

Modern Interest in the Deep Sea: Conditions of Inquiry-shape of Occan-lloors: Absence of Mountains and Val\}eys. - Coral Reefs. Continental shelf - l'ermanence of Continents.-Plants and Animals of the Sea.-Conditions of Marne Life: Absence of Seasonal Changes.-Marine Communitics-Abysmal I.ife.Detrital Accumulations. - Fate of Sunken Ships..................

\section{ICEBERGS}

Effect of Expansion of Water in Freezing.-Classcs of Icc-Ficlds-Origin of IctFloes. - Vigrations of Ice-Floes.-Origin of Icebergs.-The (irecnland cilater. -Annual Product of Icebergs; their Voyages; their Effect on the Ocean; the Order of their Movements: their Decay; their General Intluence on clinate.Transportation of Rock Débris by Icebergs.-Effect of Ice on shores.-Icebers Work in Former Geological Periods.-Dangers to Ships from Collinion with

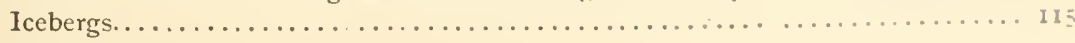




\section{HARBORS ANI) CIVILIZATION}

liirst Condition of Ships. - Orierin of Maritime Habit ; Relation of Habit to Form of Shore; liffect on National Progresn-Condition of North America as regards Ilarhors.-Requirements of a (iood P'ort.-Classification of Harbors.-Delta Harbors.-Valley Ilarbors: How Dependent on Changes of Level.-Fiord Harbors : The Conditions of their Formation; Value as Ports. - Mountain Range Harbors.Morainal llarbors............................................

\section{THE, FORMATION AND PRESERVATION OF HARBORS}

Lagoon Ifarbors; their Origin and IJistory-Effect of Wind-blown Sands.-Sand-Spit Ilarbors,-Effect of Water-borne Sands.-Crater IIarbors.-Coral-Reef IIarbors ? I)ivision into Two Classes; Ways in which constructed.-Preservation and Destruction of I Harbors; Ways in which they Act; Tidlal Action; Changes of Level; Accumulation of Sediments; Invasion of Marine Waste.-Relative Importance of I)amaging Agencies in Lake and Sea Harbors. - Effect of Pocket-

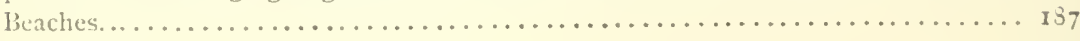

\section{TIDAI, CURRENTS AND ORGANIC LIFE IN HARBORS}

Effects of Tides on Ilarbors: Organization of Tidal Streams ; Effect of Tidal Bars.Action of Organic Life in Ifarbors; Classes of Work done.-Effect of Marine Plants; Flowering species; Sea-Weeds.-Growth of Marine Marshes: their Relation to Tidal Currents; their Value for Tillage.-Tropical Marine Marshes.Effect of Mangroves on these Areas.-Effects of Organic Life on LIarbors: Work done by Mollusks; by the Common Oyster; Comparison of Northern and Southern Marine Marshes; Work done by other Animal Species. -Synopsis.......... 223 


\section{LIST OF ILLUSTRATIONS}

\section{FULL-PAGE ILLUSTRATIONS}

VIEW of the Extremity of a Greenland Glacier,

Frontispicie

Facing Pase

PoINT FinNin, CALIFORNIA,

General View of Dunes,

View at the END of a Glacier, Showing an ICEDERg JU'ST REadi to

SEPARATE, .

VIEW OF A LARGE BERG

JUPITER INLET, FLORIDA,

A BARRIER BEACH,

A HOOK SPIT HARBOR,

A Wall BEACH, . . . . . . . . . . . . 218

128

136

$19+$

$\lg ()$

- $19 \mathrm{~S}$

\section{ILLUSTRATIONS IN THE TEXT}

Shakespeare Cliff, Near Dovir, England,

Tantallon Castle and Bass ROCK,

Natural Bridge, Santa Cruz, California,

Yesnabie Castle, Orkney,

Barra Head, OUTER HeBrides, 


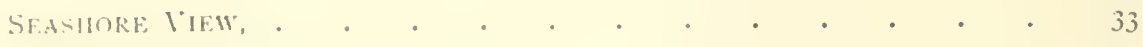

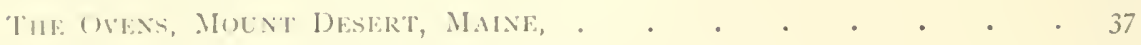

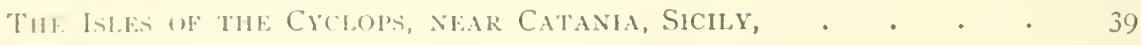

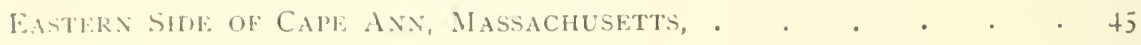

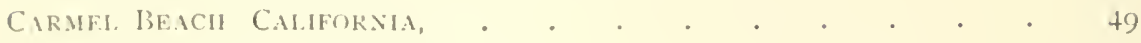

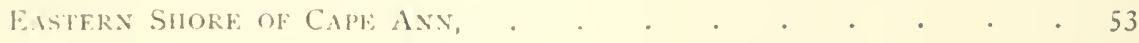

MEAYY SURGES ON BEACH SHORE, . . . . . . . . . . 58

MOIFRATE SURGFS SIEN AlOA(; THEIR CRESTS, . . . . . . . 67

SKFTCH SHOWING "THE ARRANGEMGNT FOR DREDGING IN THE DELP SEA, • 77

DHARAM SHOWING THE PUSITION OF A DEEP-SEA DREDGE AS THE LINE IS

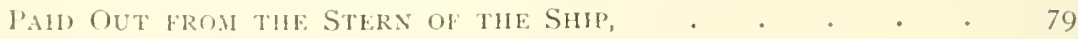

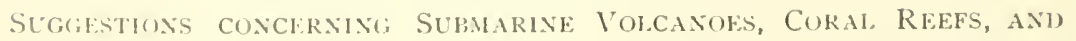

VOLCANIC ISLANIS, . . . . . . . . . . 8 8

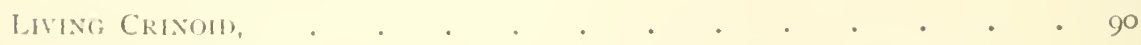

CAWX, ARMS, AND A PART OF THE STEM OF A METACRINUS-ONE OF

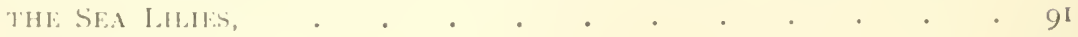

ANTHNARIUS, . . . . . . . . . . . . . . 96

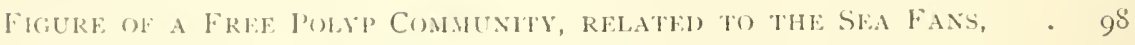
JIGURE, OF A SPONGE, SUCH AS INHABITS THE DEEPER I'ARTS OF THE

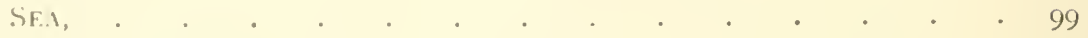

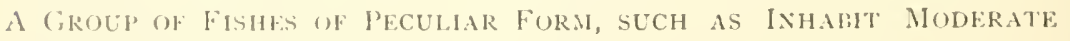

DEPTIS IN THE SEA, . . . . . . . . . . IOI

STERNOTTYX DIAPHANA, . . . . . . . . . . . . 102

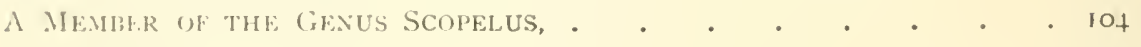

GinHARINA, . . . . . . . . . . . . 106

TOMUPTERIS, . . . . . . . . . . . . . . . . . 107

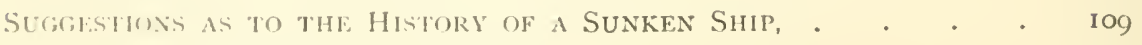

VIEW ON THE COAST OF GREFNLAND, . . . . . . . . 118

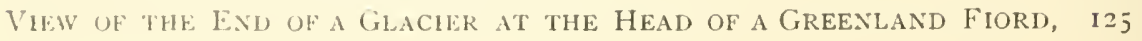




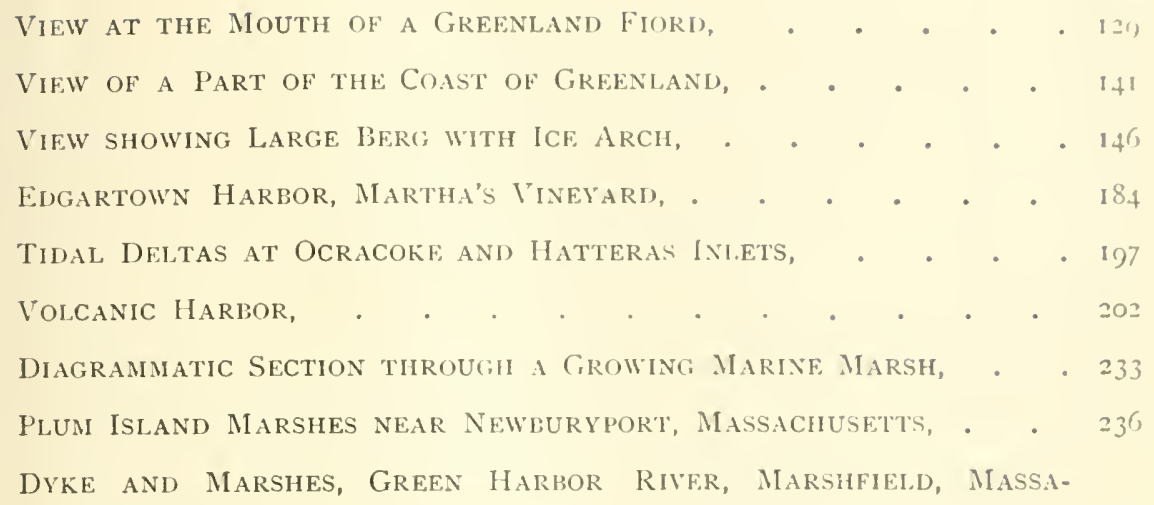





\section{SEA AND LAND}

Ilow Energy Comes to and Acts upon the Farth's Surface.-The Work of Watcr on the Coasts.--Facts to be Noted on a Coast-Line. - Land constantly Wearing away and Sea-floor Receiving Sediments. _Slight Effect of Sea on Rocky shore. - Effect of Shore Currents.-Trap-Dykes.-The Great Yorkshire Wave-Terrace.-Sea-Caves.-Frost and Ice.-Organic Life.-Elevated and Submerged Beaches.

Ox the greater part of the earth's surface men may dwell unconscious of the fact that the earth is a laboratory which is day by day accomplishing constructive work-work which in the process of the years and ages brings about revolutions in the forms of land and sea as well as in the nature of their climates, and thus alters all the conditions of life. Those who live near active volcanoes, or in lands which are frequently shaken by earthquakes, now and then have evidence brought to their attention which shows that this globe is a work-shop wherein much is clone; but in most lancls the order of nature is so quiet, and its processes so familiar, that the whole appears merely commonplace. It is otherwise. however, with those who dwell in the peculiar realm where the great reservoir of the waters comes in contact with the land: on the ocean's shore the processes of change are so marked, man's combat with them so continued, that all mariners, and even those who reside near the sea, acquire a far more vivid impression of the earth's activities.

The beginner in geology should at the outset of his 
studies endearor to acpuire certain general notions as to the way in which enerey comes to, and acts upon, the surface of the earth. Ife may well berrin his steps towards this understanding by noting the fact that all the morements which take place on the land and in the sea, from the storms to the pulsations of his own heart, represent the action of forces which originate in the sun. From that great master of the solar system there goes forth such a tide of energy in the form of light and heat, that even the small share which falls upon this little grobe is in quantity vast almost beyond understanding. Some conception of it, however, may be obtained in the following manner by a simple experiment. Let the observer put in a ressel containing water at a temperature of $32^{\circ}$ Fahr., or just above the freezing point, a pound of ice. bet the vessel be placed orer a fire, so that the time required to melt the lump of ice may be noted. It is well, indeed, to have two ressels, each with the same amount of water and of like temperature, the one with all the ice it will float, and the other without any frozen water. It will be easy to note in this trial that a great amount of heat is taken up, or, as the phrase is, rendered latent, in melting even a small quantity of ice. But in a single day there comes from the sun to the earth enough energy in the form of heat to melt about \$,ooo cubic miles of ice, or enough to cover the area of the State of Massachusetts to the depth of, say, 5,000 feet. It is well to remember that the amount of heat which comes forth from the interior of the earth in the same period probably does not exceed the quantity required to melt somewhere about 100 cubic miles of frozen water.

When it comes to the surface of the earth, a considerable amount of the solar heat goes quickly away again, by radia- 
tion, into the celestial spaces. It all in the end finds its wa! back to that cold realm, but before it leaves the atmouphore it does work of varied kinds; converting water into vapor, it lifts the material into the air, whence it desecends in the form of rain or snow, each in their way capable, if they fall upenn the land, of cloing a great cleal in the way of greolowical decels before their water is returned to the sea. By setting the air in motion and thus creating the wind. the solar heat sives rise to the waves which may roll over the leep, gathering energy as they gain in height, until, arrested at the shore. they apply their stored force to the work which is lone along the coast line. Not only should this large view be entertained at the outset of the student's inquiries, but it should be again and again taken into mind. in orler that his thoughts may not altogether be lost in details, but that they may seize upon these large truths.

All those who would find an easy way to a conception of the most important facts of geologic science should take up their inquiry on the coast-line: if they understand the processes which are there in operation-they are indeed easily. understood-they will gain a clue to some of the most important truths of geology. The portion of the earth's machin. ery that may there be seen in operation, or mily be readily. inferred from that which is visible, is of the utmost importance in the development of this sphere. It is only necessing clearly to see what is going on upon this part of the land and ocean, and then to conceive the conditions arising from the accumulation of these effects through the ages of the pust, to bring before the mind that picture of the slow yot majestic progress of the earth's history which it is the peculiar privilege of the geologist to win from his stuclies. 
In selecting a portion of the shore for his first lessons in geology the observer will do well to take some care in his choice; the field should, if possible, afford cliffs of bed-rocks of varied hardness, masses of dyice stones, and stretches of sandy and pebbly beaches; in these conditions he will be able to note the important differences in the action of the sea arising from its diverse circumstances of contact with the shore. It is best that the waters should be rich in the life of marine plants and animals, and the land forested to the margin; for the relation of the earth's work to living creatures is likewise important to his inquiry. Fortunately the shores of this sort are abundantly provided for the student's use. The eastern coast of the United States, from the mouth of the Hudson River to Labrador, the western border of the continent, from San Irancisco to Bering's Straits, the northern coast of Britain, from Scarborough on the coast around by the chalk downs on the south, as well as the northern shores of the European continent, afford ideal fields for this class of stud. ies. It is only when the student has become well versed in the great array of actions which he may observe within a few miles journey in any of these fields, that he will have occasion to undertake special journeys to see peculiar aspects of the coast-line, such as are afforded by the coral reefs of Florida, or the singular effects produced where active volcanoes build their cones along the shore or up from the depths of the occan. Interesting as these special features are, they are only incidental elements in marine work, concerning rather the professional geologist than the amateur.

Arriving on a shore such as we have advised the observer to select, he is likely to be at first confounded by the multitude of the facts which this line of interacting land and water 
exhibits. These facts are, as is the case with all the extencled phenomena of nature, much entangled with each other; all united in the common features which the earth always presents to the untrained eye. It is well for the student to

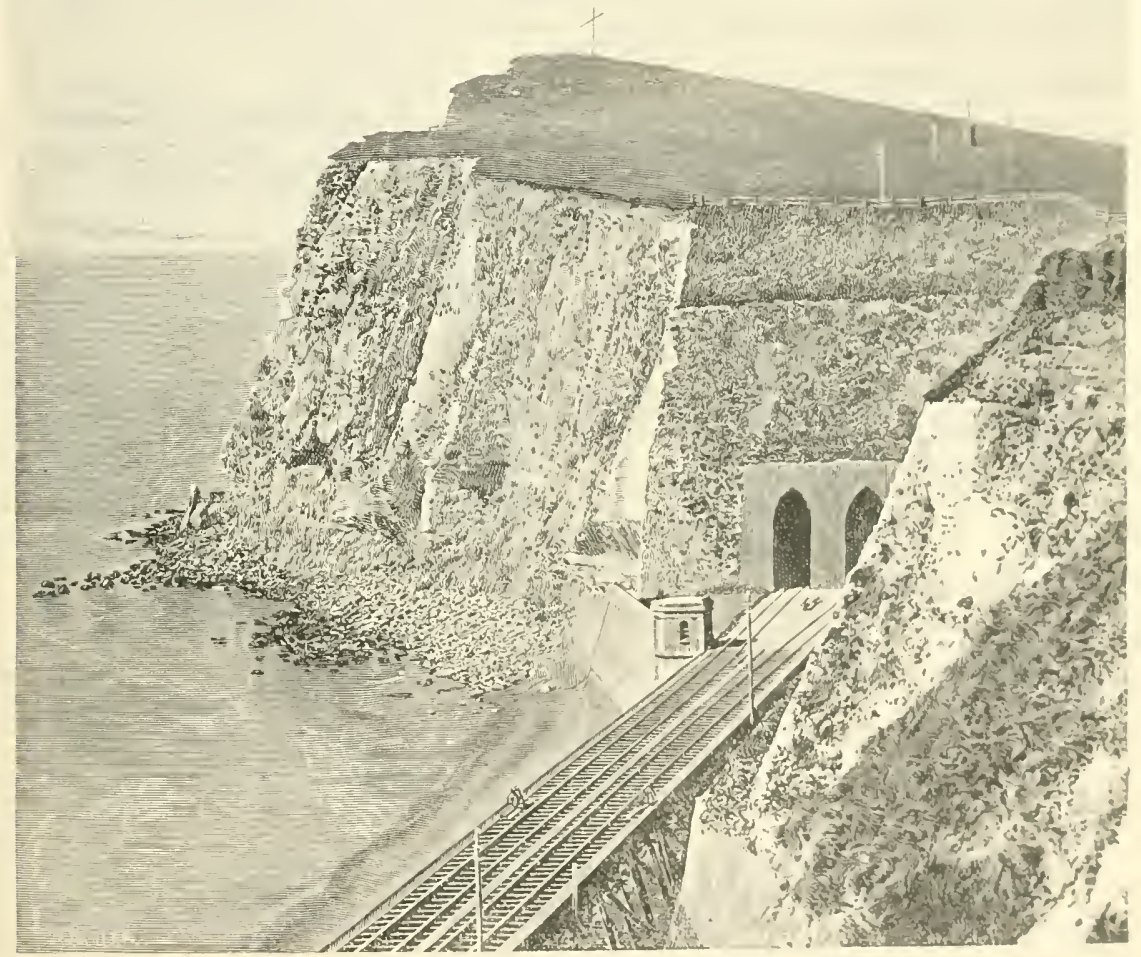

Shakespeare Cliff near Dover. England

Showing the effect of heary waves on rather soft rocks. The stcep beach at the base if the ciff $14 \mathrm{~cm}$ posed of fragments of flint originally scattered through the mass of chalk which forms the hesulian t In times of heavy storm the sea enters the slight caves which appear in the lower portion ci the preeyrec Recently fallen masses are shown at the extremity of the headland.

remember, as a protection against discouragement, that this blended aspect of the work which is done on the earth. is what appears to every beginner in inquiry. All science indecel has come to exist through the patient labors of students who 
have slowly done the work of unravelling the tangled web of interlaced actions, some part of which in turn every faithful observer must with the teacher's aid repeat. It is not to be expected that each individual seeker for truth shall go through all the laborious processes of thought which have made the science which he seeks to acquire; it is the part of his guide to show him the road through the wilderness, to keep him from the blind paths which lead to no profit; but, if he woukl acquire the strength which can come from his personal activity, he must patiently tread the way himself.

It the outset this gruide may well ask the novice to have in mind certain large truths of geology which may serve as a background upon which he may frame the special conceptions which will come to him from his shore-line studies. He may be assured that all these general conceptions will be more or less verified by the work which he is to do. The first of these concerns the contrast between the essential conditions of the two great divisions of the earth's surface, the land of the continents and islands, and the water-covered areas of the seafloors. All the land above the level of the oceans which is somewhat unreasonalbly called dry, for it is everywhere flowed over and leached through by water, is subjected to continual wearing by the action of the elements. Every rain-drop as it falls and strikes ground unprotected by vegetation takes away a little of the earth. The streams bear away much-each of them sends its tribute of mud, sand, or dissolved rocky matter to the sea ; and the ocean itself, by its unending assault upon the shores, is wearing away the land along all coasts save where the coral reefs build effective walls against the waves. All this water of rain-drop, spring, or stream, is sent from the sea through the air for the direct downward attack 
on the emerged fields of the earth; the battle the oceant unendingly wage is so set that it assaults the opposing lamel in two directions: on the sea face it assails by the surmes, and in the interior by the rain, the flowing water, and the glacicrs. The result is that the lands are constantly ucaring away, while the sea-floor receives the sediments which the watur have given to it and builds them into new deposits.

The effect of this action, if it were not qualified by other conditions, would be that in time the dry parts of the earth would utterly disappear and the seas be in grood part filled with the waste they had won from them; but there are compensations to this action. the lands are constantly groming upward from the action of those forces which elerate momtain-chains, probabiy also the whole of the vast ridge which constitutes the body of each continent is also characterized by a massive upward growth; at the same time the ocean basins seem to be ever deepening by the downsinking of their lloors. The result of these beautiful compensating movements is, that although the contest between land and sea is the must ancient, far extencled, and unbroken of all the many combuts which make up the life of this sphere, neither side is crer victorious or is ever likely to prevail. It is incleed unly in a metaphoric way that it can be called a battle at all. for the results of the interaction are profitable to the interests of sea and land alike. On the land the continued wearing luat the most important result, that the soils on which all its urainic life depends are ever renewed by the destructive procusies of crosion. If any considerable time went by without th oll soils being swept away, the effete carthy matter woul 1 become unfit for the nurture of plants, and plant and animal life alike would fail of support. This waste, in pare distienlred in 
water, nourishes the marine life, and in part in the form of mud is contributed to the strata which in time are to be lifted into the air with the upward growth of the continent from whence it came. Here as elsewhere modern science has shown that the strife of this world is only apparent; the result, considered in a large way, is always for the profit of the whole.

With such a broad preliminary survey in mind, the observer may well begin his detailed studies of the shore at some point where the sea and land meet in a steep rocky cliff which descends abruptly, there being a depth of one hundred feet or more next the cliffs, from its crest into the sea at its foot. It is easiest to inspect such a bit of shore at a time when the ocean is quite still; for then it may be approached in a boat. On the northern coast of the Atlantic, from New York northward, these rocky faces of the shore are generally more or less rounded by the action of the moving sheet of ice which lay upon then cluring the last glacial period. We are very likely to find the upper portion of the steep, that which is above the level where the waves clo their work, still bearing here and there the scratches which so plainly tell of the ice time. Occasionally, when the water at the base of the cliff is deep, this glaciated surface, if the rock be firm set, is preserved even within the belt where the surges impinge upon it. This fact tells us that the sea has under certain conditions little effect on a shore of this nature. This is made the clearer by the presence on the surface of the stone of a mass of marine animals and plants, algxe, sea anemones, etc., which, firmly adhering to the stones, can resist the blow of the waves. If in times of storm we creep to the verge of such a cliff we may see the waves 
surging violently against its base, but we observe that they do not strike an effective blow, but merely swash up and clown, as they break against the steep. As we shall shortly see, their action is impotent as compared to what it is when the cliffs do not descend into deep water, but have somcthings like a beach at their base.

The fact is that the ocean waves, when they beat aurainst a rock-bound shore where the firm cliffs descend into deep water, have very little destructive power. When they strike the shore they may apply a pressure of from one to three tons per square foot of surface against which they run, but this can only break away the masses of stone which have been loosened by the action of frost or the other processes of decay. On a shore which has recently been overridden by the glacial ice, the weaker kinds of rock have been pretty generally worn away, and it is only slowly that they yield to the sea's assault. Yet, now and then masses tumble from the top of the cliff, so that here and there, even on the steepest shores, we find where the débris from the precipices has been sufficient to make a beach-like accumulation such as is shown in the illustration (page IO). As soon as this mass of clébris comes near enough to the surface to be much affected by the dragging action of the wares as they surge against the stecp, the stones are arranged by the waves so that they assume more distinctly the beach form. In this state of the shore the surges are at last able to do their effective work. Nie may observe them rolling in from the deep in the form of brond folds of the ocean's surface; when the adrancing margin of each wave arrives at the shallower water at the outer part of the inclined plane of débris, the friction of the bottom opposes the forward movement, and causes the front of the 
surf swifty to rise into the form of a wall; the upper part of the mass of the water being less retarded than that at the base, shoots violently forward, and near the shorc tumbles over in the manner of the familiar breakers or surf.

When the waves break at the foot of cliffs they then strike much more effective blows than when they splash against

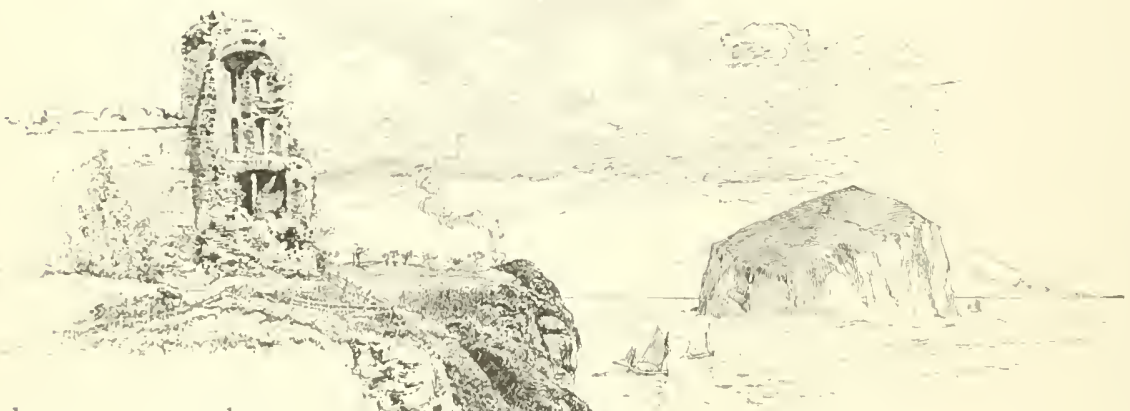

them, as they do when they roll through deep water to their base. Rushing orer the shallow

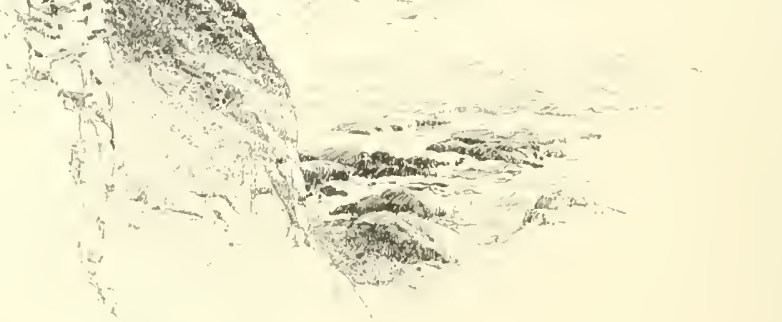
bottom in times of heary storms, they hurl the loose stones, even if they weigh a ton or Tantaion Castie and Bass Rock more, forwarel against the base of the cliff. The blow these ware-swayed stones can strike is very great; it is sometimes almost as powerful as that which is delivered by a shot from an ancient battery argainst a besieged wall. If the student will watch the action of the storm-waves upon a coast 
where they have the effect we are describing, he will note that, both to eyes and ears, the results are very dillerent from what he observed in the part of the shore where the cliffs descended into deep water. Against the stecp cliffs there were no combing breakers, and the waves gave forth only a muffled roar as they struck the steep; herc, however, they rush up the stony beach in a confused white mass of commingled water, air, and stones. As the mass strikes the base of the cliff we hear the roar of the waters, and the keen ear can detect also the crash of the stones as they stritie against the base of the cliff.

If after the storm has ceased the obsarver will, at a time of low tide, risit this strand which he could before see only from a distance, he will be able to examine the result of the wave-work. At the base of the cliff where the surges have beaten, he will generally find that the rocks have been rudely cut out by the blows which they have received, so that the upper part of the steep somewhat overhangs its base; he ma! note where great masses of the stone deprived of support have slipped away from their bed places, and fallen to the strand. Some of these have been too large for the wares to toss about, and they remain as angular fragments somewhat rounded, it maty be on the side toward the sea, by the battering they have received from the pebbles which have bec.n hurled against them. Other and smaller pieces of the herl. rocks which have fallen from the overhanging steep have hech worn against the base until they have had their sharp comers beaten off; yet others have been ground into spheres hy the pounding they have received, looking like the stone cannonballs which in early times served in siege-gums. Putting these facts together so that their whole meaning is plain. the 
student perceives that in a single very great storm the face of the cliff maty be worn back to the average distance of some inches, and that the retreat of the upper part goes on more steadfastly, but in an inevitable way, as the stones of the overhanging precipice are loosened by frost and clecay.

IIe can often trace the distance to which the sea has cut back from the place where it was left at the last change in the level of the land, by the broad rocky shelf leading off to the edge of the leeper water. Sometimes, as in the coast of Yorkshire just south of Whitby, this extends as a flat table of stone at about the level of low tide, to a distance of a mile or more from the base of the cliffs. On this Yorkshire coast the cliffs rise in places to the height of six or eight hundred feet, and are so stecp that it is impossible to climb them. Shipwrecked mariners and persons who have been imprisoned against their base by the swift rising tide have to be rescued, if they are saved at all, by means of baskets or ladders lowered from the summit of the escarpment. A similar, though less extensive, wave-worn shelf extends along the southern shore of the island of Anticosti, in the Gulf of St. Lawrence, for the distance of more than one hundred miles. There as elsewhere ships are apt to strike against the margin of the wave-shelf and to go to pieces or fall away and sink in the deep water which borders the ledge. The great distance to the shore, and the wild tumble of waters which a great storm produces on the rocky table, make shipwreck in these conditions peculiarly hopeless for the mariner. Shores of this nature are always formed where the open sea is bordered by hard rocks and has remained for a long geologic time at the same elevation with reference to the assault of the waves. Where a rocky shore does not exhibit these features we may 


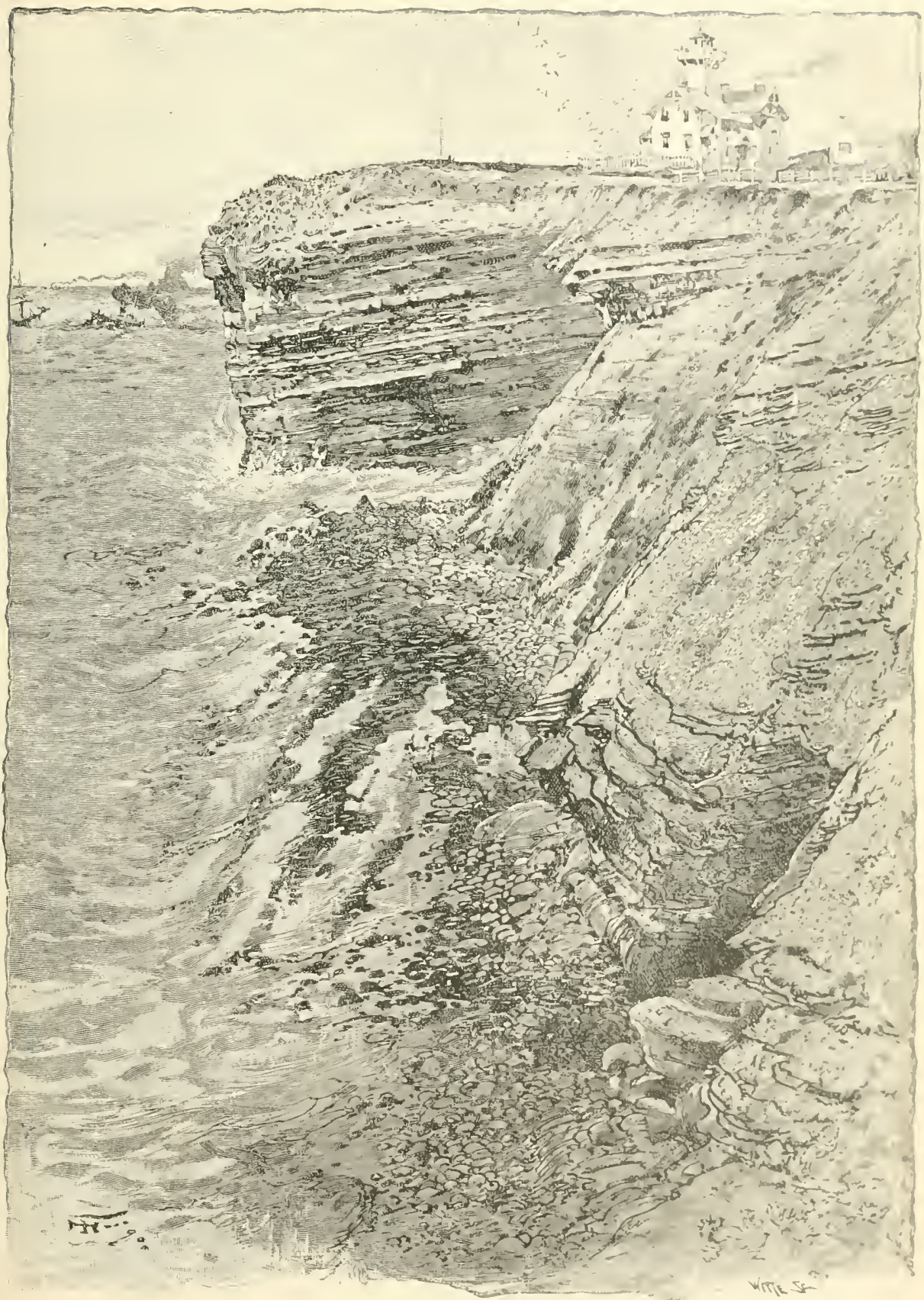

Point Finnin, California

The view shows the effect of the sea on a shore composed of stratified rock of moderate haruness which dit toward the ocean. The harder fragments of the strata form a shingled beach, the fragments of which in tume of storm are driven against the base of the cliff. 

be sure that the position of the coast has been recently. changed, that the land has been either lowered or uplifted.

It is a feature deserving attention that these wave-benches rarely retain on their surfaces any consiclerable part of the débris which has been removed from the cliffs: here and there, scattered over their surfaces, we find bits which have been fastened in the crevices of the bench, but except where fresh fragments are supplied by the fall of the masses of rock. the wicle surface is usually as clean as a floor. 'This feature is peculiarly well shown on the great Vorkshire wave-terrace, but is noticeable in all similar structures. It is, in a word. evident that all the matter torn from the receding cliffs is in some way removed to a distance from the place where it falls; a little consideration and a few observations on the ground will show us the manner and the measure of its removal. Let us first notice that nearly all the detritus at the foot of the cliffs is of a pebbly nature; in general it consists of quite large stones which have been very much rounded. It is evident that a large part of the rock which has been worn from those stones was taken away in the form of powder or sand. IVe can often, in the case of granite pebbles, see that the surfaces have been crushed by the blows they have received. We readily apprehend the fact that in the mill of the surf at the base of these rocky precipices, the fate of the rocks is to be ground into a very fine grist, which is easily borne away to a distance by the strong currents which exist in times of storm.

If the waves rolled directly in at right angles to the face of the cliffs, and the wind blew in the same direction, the only current which would exist on the shore would arise from the reflex of the water and the undertow or current which sets 
out along the bottom of the sea from a beach on to which the waves are rolling. These movements of the water can, however, convey the detritus to only a little distance from the coast-line. In fact, however, the waves rarely come squarely down upon the coast, but strike it a little obliquely, and the wind generally blows in the same direction in which the wares run. The result is that there is almost always a strong current made by the water which the waves heave and that which the wind blows against the shores, which sets as a river in one or the other direction along the coast. Moreover, the tidal currents, more or less combining with these actions, add to the stream. Those who are familiar with the shore and have seen a number of shipwrecks, know that the wreckage and the bodies of the drowned usually do not come ashore just alireast of the stranded vessel, but drift in one direction, often to the distance of miles from the place of the disaster. Those who have escaped by swimming or floating on spars to the shore, have had an even more impressive experience with this swift storm-born river of the coast,

These shore currents are strong enough to sweep away a part of the detritus formed along the shore; even materials as coarse as small pebbles may be carried by it to the deeper re-entrant angles, where it is accumulated in the beaches which we are in time to study. The coarser pebbles, which are too heavy to be borne along by these currents, journey in the grasp of the waves more slowly, but ever as ccrtainly, to the beaches. The process by which they travel is this: Each wave, as it sweeps up and down the slope next the cliff, in most cases runs a little obliquely to the face of the shore, so that with the movement the fragment journeys a little way from the point where it first became rounded 
into a pebble. With each backward move of the retreating splash it is drawn away from the sea-margin, to return with the next surge. With every successive advance and retreat it may journey onward for the distance of a few fect, and - so, wearing at every stroke of the ware, it moves on. I large part of these rolling stones wear out before they attain the greater beaches.

Before we follow the waste from the point where it is made into pebbles and sand to the part of the shore where we have characteristic beaches, we must return to the cliff section to consider many interesting details of the work which is done there by the waves, tides, and the many other clements of activity which operate in this singular part of the great laboratory of nature. All who are familiar with the rockbound coasts which are much worn by the wares, have noticed the fact that the materials are very irregularly eaten away; rarely indeed is the escarpment of the cliff anywhere near a straight line: it is generally deeply indented by sharply re-entering little bays, and not infrequently presents carernlike openings which penetrate a considerable distance into the cliff. By carefully noticing the conditions exhibited by the face of the precipice at the level where the wares attack it. or, if occasion favors, by examining what takes place in times of storm, we may see how these depressions are formed. At each of these sea-caves, or other indentations, we yencrally: find that there is some structural feature which weakens the rock, so that it is more easily worn out by the wares. Somutimes there are several lines of open joints which part the rock and enable the surges to lift the fragments from their bedding places. Again, where the strata have been turned on edge, there may be here and there soft beds which yield 
readily to the battering action of the stones which the waves hurl against them; or in other cases, the rock may be riven by dykes and veins, that is, by fissures which have been filled with lava, or materials deposited by the action of water. These deposits may be, indeed most often are, softer than the stone in which they are laid, and may thus afford weaknesses which are searched out by the sea and developed into rifts and caverns.

As soon as any weak spot on the face of the cliff has been worked back a little way so that the hard bits of stone may sather in it, every wave sends these fragments with energy sufficient to wear the place yet farther back into the land. The effect of the boundary walls is to keep the rolling stones in a position to do effective work, and as they are tossed about by the waves, new bits find their way into the pocket as fast as old ones are worn out. In this way, these cutting tools are much better supplied in these recesses than along the general face of the cliff, and thus the waves do more effective work here than elsewhere. As the sea cuts only for a short distance up on the face of the steep, the excavation, if the rock be tolerably firm, often has at first the form of a cavern with a wide portal. As the chamber widens, this opening commonly becomes unable to support its roof, which falls into ruins and is ground up by the waves. The greatei part of the permanent caverns which are formed in this general manner are excavated in trap-dykes. These sometimes extend back from the sea-face to a distance of one or two hundred feet or more. Most commonly the floor of the chamber rises pretty rapidly as we penetrate from the light of day. In fact, a considerable inclination toward the water is necessary to keep the mining machinery by which 
the excavation is made in good working order; unless the slope is considerable, the inrushing waves will heap large stones in such quantities against the inner end of the opening that the surges cannot move the whole mass, and the bed-rock will be preserved from the blows of the bowleters which then expend their force on each other.

The result of this steep slope of the cavern floor is, that if the sea-cliff be low, the extremity of the cavern finally attains the surface, and gives the conditions which produce what in New England is called a "spouting horn." The waves, in time of heavy storm, rush up the crevice with a speed accelerated by the narrowing of the opening in its inner parts, and send a mass of foam high into the air. Another condition which produces an interesting group of spouting caves is found when the cavern has the top of the portal low, and a considerable space within which has no communication with the outer air except by the opening into which the wave sweeps. Rushing into the carity, the billow energeticaily compresses the air until the motion of the water is arrested; this air then, expanding, blows the water backward toward the sea, discharging a good part of it like the smoke from a cannon. This group of caverns is less noted than the spouting horns, for the reason that, though they are the more common, it is rarely possible to see them when the waves are high. It is only when some sharp headland gives a coign of vantage whence we can look down upon a long stretch of cliff shore, that these peculiar features of wave-work can be well observed.

Another group of shore features sufficiently frequent to deserve notice are the arches and natural bridges. ()n our New England shore these features are uncommon, for the 
reason that the rocks on that coist are generally too hard and too much jointed to faror the formation and preservation of these beatiful structures; but on the shore-lands of northern firitain and at many points along the Nediterranean Sea, these singular rock forms abound. I stone soft enough to be easily assailed by the waves, yet coherent enough to

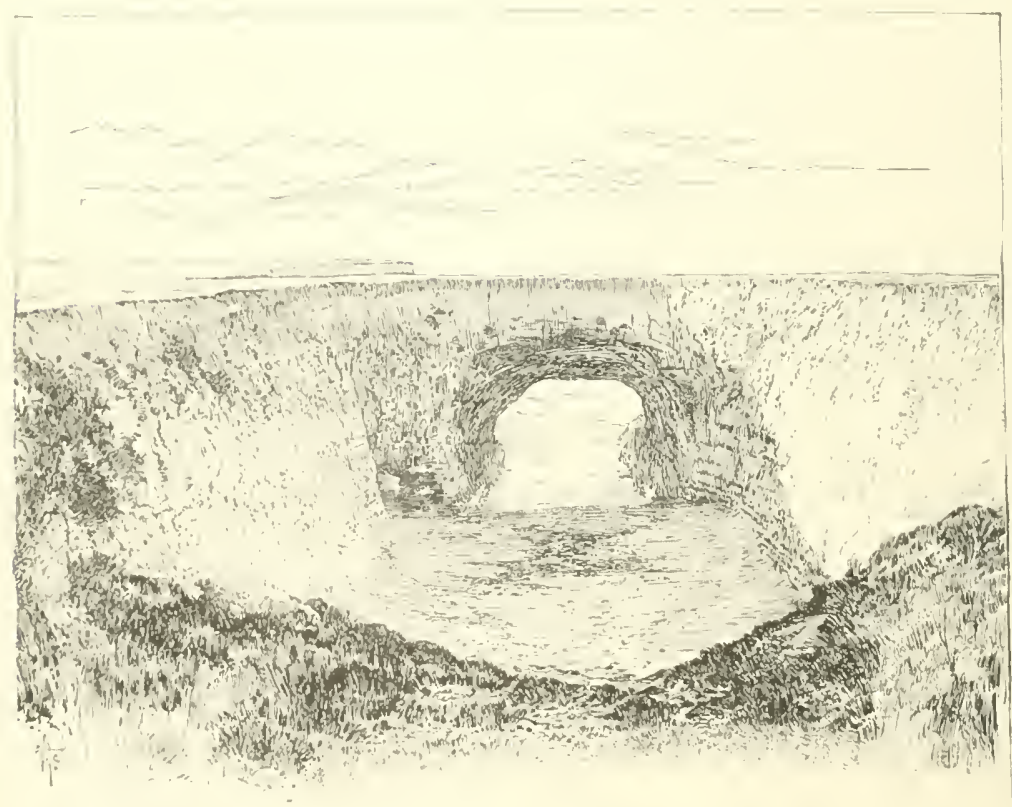

Natural Bridge, Santa Cruz, California

Remnant of a sea cave; the inland portion of the arch has fallen in. and the space has been widened by the waves which roll in beneath the bridge. The horizontal strata are of limestone, and are thus easily dissolved by the waves. The material is much jointed, and so the pebbles on the beach are very small.

hold together where the joints or natural lines of weakness run in several directions, affords the best conditions for this kind of marine sculpture.

In the ways above described the sea. searching out the paths of least resistance, will often produce very beautiful effects, simulating the noblest results of architecture. On 
the Atlantic coast the best of this class of hard! procluct of sea and rock are found in the Gulf of St. Lawrence. " d ial Roche Percée," or the pierced rock, a steep-faced isle nertr the mouth of Craspé Harbor, is perhaps the noblest areh of the eastern American coast. Many beautiful fantastic archen and natural tunnels, though never of great size, are foumb along the shores where coral reefs have been lifted a little way above the sea and exposed to the cutting action of the wares and the solvent work of the streams which flow from the land. A very beautiful small example of thesc coril reef islands is found on the western shore of the northern part of Biscayne Bay. Fla., where a little river escapes from the Everglades through the elevated barrier reef beneath a rock arch.

Yet another picturesque group of shore structures, sufficiently common to have reccired a name in the remacular. are the steep detached masses of stone known as pulpit rocki. This name is commonly given to any pinnacled stones parted from the land by a space of water no wider than could have been bridged by the voice of a sturdy old-fashioned poundtext, and which afford a good place for the imagined preacher. On other shores these islets are often so high that the conditions would not admit of the term pulpit rock: in unch cases the isolated mass usually receives some other name with clerical associations. The memories of monks and friars are often thus preserved. At only one place on our Imerican shore do I know of any of those natural monuments whith have been associated with the religious orders; this is the Old Friar, on the northwestern shore of the beautiful island of Campobello, a bit of British ground which forms the seaward wall of Eastport Harbor, Me. Even where the pleas- 
anter religious analogies do not appear in the names of these striking pictures of the rocky shores, the solemn spirit of the seafaring people who have given them their designations, seems to lead them to choose the appellations from the

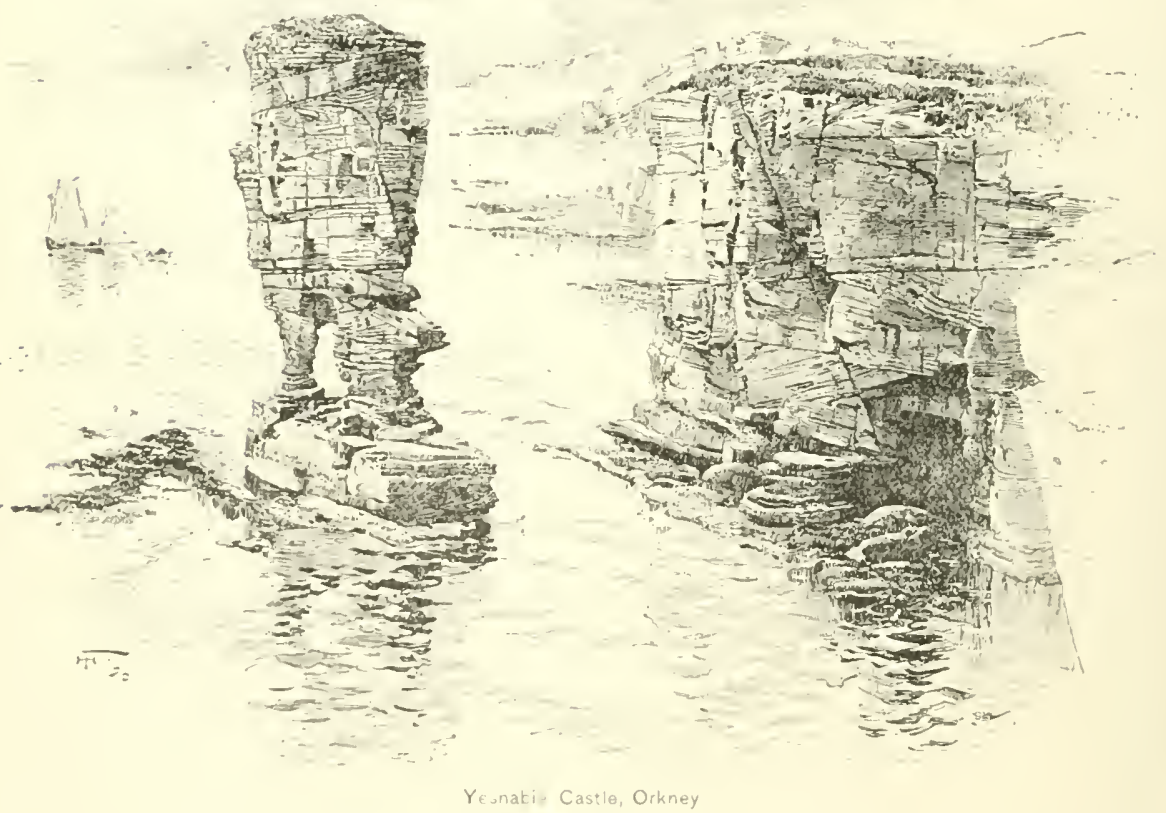

The view shows a good specimen of a pinnacied rock which has been separated from the cliff by the fong continued action of waves and ice. It should be noted that all the debris of the rock between the pinnacle and the shore has been broken up and earried away. The main cliff as well as the detached mass wows distint joints, and also bedding jlanes. The latter exhibit in a remarkable manner the phenomena if cross bedding. This sl:ows that they were formed upon or near an ancient shorc-line.

other sicle of their faith. The l)evil and his realm come in for more than a fair share of the titles hy which these notable points are designated. His Majesty's thumb, nose, and other conspicuous bodily parts, are all commemorated. 'These men of the sea appear to have found in their association with it 
more solemnizing influences than come to their brethren of the inland country who dwell amid milder conditions.

The circumstances which lead to the formation of these curious detachments of rock from the parent cliff are sub. stantially as follows: The shore precipice being rent lyy numerous crevices or joints, it here and there happens that these lines of weakness lie in such positions that they intersect each other as the excavation is pushed into the land. Working, as we have seen the waves do, more efficiently in these recesses than on the smooth cliffs, the intervening mass of the steep does not rececie so rapidly, and so is left as an outlying fragment around which the sea washes at low tide. The observer will note that in general these pulpit rocks have a prow-like projection turned toward the shore. This shape is due to the fact that the joints or other lines along which the waves work, intersect each other so as to form the wedge-shaped block which in time becomes detached. One of the most ordinary causes of the peculiar wearing which we have to note here arises from the crossing of dykes, or fissures filled with hardened lava, which, like that thrown out by volcanoes, was once molten. These dykestones are often composed of very fissured rock which the waves easily disrupt and bear away: it often happens incleed that the material resembles a mass of billets of mood heaped closely together, as in the case of the Cirant's Causeway of northern Ireland. When frost acts with vigor, as it does along most of the shores where the pulpit-rock structure occurs, its effect is greatly to aid the surges in rending anay these dyke-stones, while it maly have very little influence on the more compact parts of the cliff.

The action of freezing and of frozen water along all cliff 
shores in high latitudes is very great. In such regions, indeed, the coast line has a very different aspect from what it has in latitudes where water always remains fluid. In the act of freczins, water expands about one-ninth of its mass. Thus on our northern shores, when the tide recedes for a considerable distance from the cliffs, the water exposed in

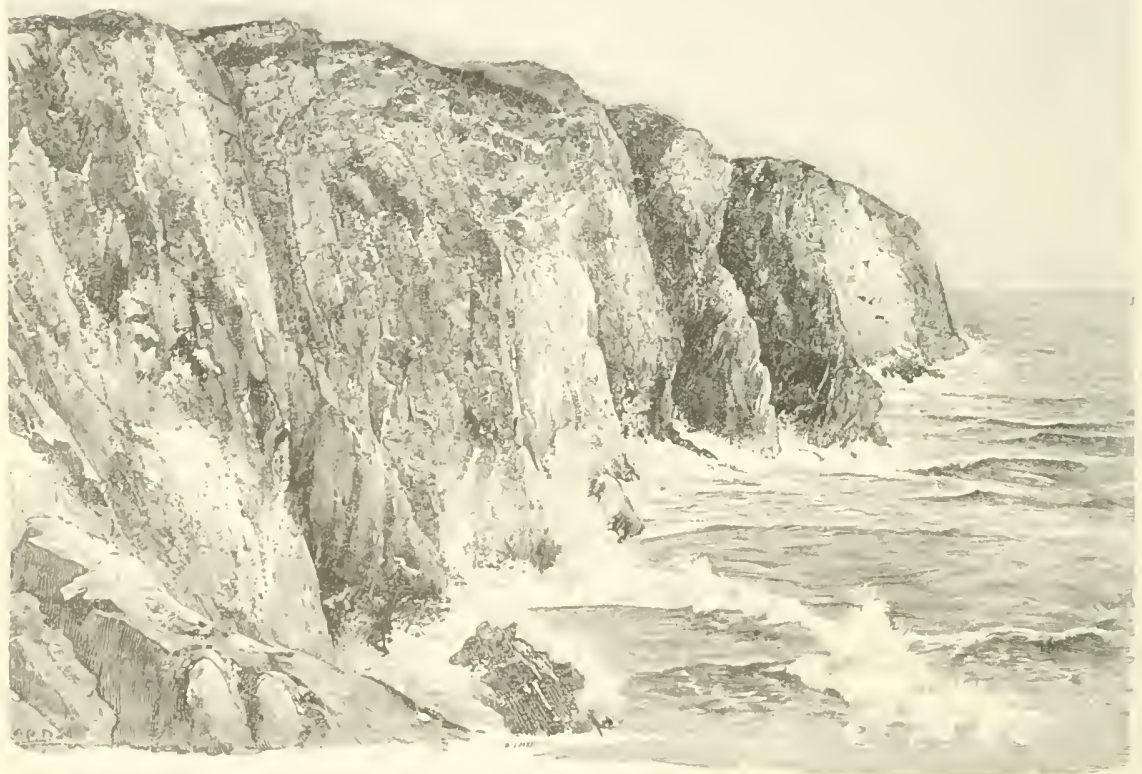

Batra Hoad Outer Hebrides

Shrwhy the action of the sea on massive but somewhat jointed rock, the batse of whrch lies at no great depth beneath the surface of the seat. The cffect of dykes is shown in the deep recesses in the middle distance A lare tragment which has fallen from the undermined eliff is seen in the foreground.

the crevices often congrals to the distance of some inches from the face of the rock. Expanding in the opening, it produces an effect like the wedges which the quarryman uses in his art. Every cranny is sought out by the fluid; many fissures which are not evident to the eye are thus forced open, and so the fragments of the stone which the greater 
storms have rent from the cliff are brought to a size where: the lesser waves can toss them about. In this way the: frosted shores are able to present steeper cliffs than these: which are not thus affecteel, and when all the work hais to be done by the action of the wares with such slight asistance as the slow chemical decay of the rocks may afforel.

While the expanding action of the frost is clouljtess most efficient in wearing back the face of rock-cliffs, the ceffect of the ice which gathers along the shore is probably of yet more importance. In all times of comparative calm, when the temperature is low enough rapidly to freeze the watc next the shore, the ice gathers in cxtensive fields and often becomes heaped up by the drifting of these areas until it has a thickness of ten feet or more. When the tick is low the stones become fixed in the mass, and by the current, when in this position, are driven as rasping engines againat the base of the cliff. In this way the ice-imprisoned stones continue the work which the winds have begum, and accomplish a great deal of abrasion. The most important influence of the ice-fields, however, is to clear awat from the shore the excess of detritus which the waves may have accumulated there. The reader may often observe points uhere this mass of stones is so great that the wares are fermed from the cliff which they are assailing. except where the tide lifts the surface of the sea to its greatest hoinht. Thus it may be, for a few hours in the twenty-four. they may strike against the base of the ocean cliff. I singie heow and enduring frost may so bind this detritus inte the icefield that the tide, alided by a strong wind from wif the shore, can drift it all away to be dropped on the bottom of the deep sea possibly miles from the coast-line. Nuarly all 
the rocky shore of the Atlantic coast, that is as far south as New lork, beyond which point to the southward there are no hard rocks facing the sea, is kept, by this peculiar action of the ice-floes, in good shape to be assaulted by the surges.

The realm of nature exhibits a conflict of marvellously related operations; scarce any of her agrents are able to act with perfect freedom; we therefore may not be surprised to find that the work of frost and ice is much qualified by other actions. I'e note among these conflicting conditions the effect of the coast-line sea-weeds on the effect of frost. From a point a little below high tide to the border of deep water the rocky shore is usually covered with a dense growth of these lowly plants. The growth is generally so thick that we cannot discern any part of the rock. When the tide has a great rise and fall, as in the part of the coast about the eastern coast of Maine and New Brunswick, a journey along the shore at low water will give the student one of the most startling impressions which his studies can afford him. The steep cliffs are hung with a sombre arras of funereal hue made up of those pendant fronds which cover the rocks to a depth of a font or more. Observing these plants when they are floating in the water, we perceive that they are buoyed up ly numerous arr-bladders which develop in their tangled leaf-like foliagre. These air-bladders, as well as the air entangled in the mass of the matted stems which cover the rock, serve in a measure to kecp out the frost when the shore is bared at the retreat of the tide. The coating acts as an excellent nonconductor, and by it our shores in high latitudes are in a large measure protected from the destruction produced by the expansion of freezing water in the rock crevices. 
In a somewhat similar, but, on the whole, less effective way, protection against frost action is afforded by the coating of animal life which abounds on the rocks of the sea-shore. The barnacles are the commonest of these dwellers of the surges which have by various contrivances managed to withstand the rude blow of the waves and win a profitable place amid this field of dangers; but the numerous shells termed limpets, and a host of other delicate but exquisitely adjusted creatures, maintain a foothold there. The fact is that the fiercely contending waters of a rocky coast-line afford a singularly favorable place for animals to find food. Every stroke of the waves rends away bits of sea-weed from the rocks, and grinds the fragments into bits which may be seized on by the expectant mouths. The winds drift rast quantities of organic matter from the deeper sea, which receives like treatment from the mill of the surf. The result is that the water next the shore is a rich soup or broth capable of nourishing a rast amount of animal life. On sandy coasts there is no foothold for such creatures; if they were placed there the first wave would cast them into the mill; but on the firm-sct rocks they can, by various most ingenious devices, manage to make arail of this chance for subsistence. One may judge how wellspread is this table of the shore by taking a glass of water from the turmoil of the surf: we see that it is crowded with the débris of animals and plants, all of which is good nutrition for these marine creatures.

To win security against the waves, and thus to be able to get safety and feed at this richly furnished hoard, the shore animals have for ages been most assiduously contriving ways of securing themselves to the rock. Thus the barnacles. whose remote ancestors were frec-swimming creatures some- 
what like the shrimps, ixsan by alhering by their head-parts to floating timber or rocks not much exposed to the waves, and sradually, by one change after another, all apparently designed to the one end, have come to a nearly perfect reconciliation with the conclitions which surround them. Their original form is no longer recognizable, for they are now cased in a cone formed of stony plates, and only these parts fairly anchored to the rock on which they rest. Their netlike fringe of arms can, whenever for a moment the sea is still. sweep) the water aloout them; and when the surge is about to strike, witholrawing in their shells, which by their shape part the wate, they are perfectly protected. So, too, the limpets have converted the ordinary smail-like shell into a stout bucliler, which, when lifted as the wave withdraws, almits the seawater with its nutriment. As the water closes down on it the celuge of the shield comes upon the surface of the rock, and is helel there by the strong muscle which forms a large part of the animal's hody. Animals and plants pay with infinite toil and pains for their chance to secure food in places where they are fatirly protected asainst organic enemies. The surf line is by its conditions the best provisioned part of the sea: it is free from creatures which can prey upon its inhabitants; and to sain a place there, it is worth while for any creature to make many sacrifices.

While the effect of this organic life, both animal and veretable, is mainly protective, by fending off the frost, and to a cortain oxtont diminishing chemical decay, there are certain animals which themselves assail the rocks and, in a measure, hasten their destruction. A whole group of shellfish related to our common mytilus, the sea-mussels of the vernacular, are known as lithodomes or rock-house makers. 
They, in some way not yet well known, lut probahly by the rasping action of their shells, cut out little chambers in soft rock which sometimes attain a depth of several inches. Where these creatures are numerous they honcycomb the stone and make it so frail that the waves can break it 11p. Certain of our echini, or sea-urchins, have in yet sreater measure this ability to bore into the rocks: they can by the movement of their frail-looking spines tunnel cownwat in materials as hard as granite; as their bodies are larger than the lithodomi, they bore much greater holes. These cham. bers are often as much as two inches in diameter with a depth of a foot or more, and afford one of the most remark. able evidences of the effort which organic forms make to avail themselves of the profit which the shore conditions afford. So far as has been observed, this habit of rock-boring on the part of the sea-urchins is not known among our American species, though it is common among their kindred on the shores of Europe.

Hitherto we have been considering the action of the ocean waves and currents on shores where the harder kinels of rock meet the sea. Although this is the commoner condition of the coast in its cliff-bordered sections, there are many steep formed by the frailer rocks, such as are afforded by the grlacial deposits of northern countries or the incoherent strata of the newer geological fermations, when the hits of such beats have not been bound together in the firm way in which we find them in most old deposits. Along the coast of the Atlantic, from the mouth of the Hudson to Greenland, particularly in the southern portion of this shoreland, are hundreds of miles of steeps where the sea beats directly ayainst these yieldin: materials; operating on these cliffs the sea-waves do not have 
much difficulty in breaking down the strata; at every stroke they srive way along the face of the cliff, and the frail werhanging mass quickly drops down to the shore. There are of course no sea-caverns, no penetrating chasms, or other irregularities which indicate the slow and difficult siege of the sea arainst the stony walls of the hard-rock shores. Such coast-lines are usually straight and present little that is picturesque, except when, as at Gay Head, Mass, and at Alum Bay, in the Isle of Wight, the soft strata are of varied colors and perhaps tilted and folded in complicated ways; in such cases the cliffs may have a marvellous beauty of hue to redeem their lack of variety in contour.

The only difficulty the waves have in making a rapid conquest of these soft clifis arises from the talsk of clearing the waste accumulation of débris which comes to them from the yielding rock. Except where the beds contain large numbers of great bowlders, as is often the case with glacial cleposits, there is no such resistance as arises from the need of grinding up the rock into bits which the currents can carry away, for it comes to the waves in a comminuted form. The burthen of this work of destruction falls upon the currents, and the speed with which the cliff is worn away depends upon their ability to remove the fallen material from the point where the waves have delivered it to the sea. It is rare indeed that these currents can in their work keep pace with that of the waves: in laruge measure this débris remains just to the seaward of the shore-line, and is only slowly removed to a short distance, to the neighboring beaches or to the deeper parts of the water: in this position next the shore, it so far shallows the water that all the greater waves break at a distance from the face of the cliff, and only the lighter splash waves attain 
its base. Graclually the undertow of the breaker drass the débris to seaward, and the varying currents produced by the tides and storms remove it from the precipitous shores to the pocket beaches. where, as we shall see hereafter, it is ground to powcler. The result of these causes is one of the many beautiful adjustments of activities which the study of the shore brings to our attention. The waves excavate only what the currents can take away; if at any time they cut out more débris than is removed, their energy is diminished by the shoaling of the water next the shelf; if the currents clear away more of the waste, the surges are for a time free to act and deliver more sand and gravel to the sea. Thus the processes of excavation and of carriage become accurately balanced with each other.

It is on these soft-rock shores, where strong currents operate, that we find the swiftest conquests of the sea over the land. On the hard-rock cliffs the erosion rarely forces the cliffs inward at a greater average rate than a fraction of an inch a year, while on gravelly or sandy shores the rate often exceeds a yard per annum. Thus, on the coast of Cape Cod, near Chatham, the shore is retreating into the land at the rate of at least a foot each year. On the southern shore of Martha's Vineyard, the recession of cliffs which are about one hundred feet high, has been, on an average of forty years, about three feet. and on the southern face of Nantucket, near Surfside. the retreat of the escarpment has been as much as six feet. in a single year. Although composed of somewhat harker materials, the island of Heligoland, in the north of Germany. near the mouth of the Elbe, exhibits a similarly rapid process of destruction; though within the historic period it was a tolerably extensive land, it has shrunk before the surges of the 
sea until it has an area of only onc or two square miles; it secms doomed to complete effacement within another century. So, tou, the (xoodwin Sands, now only a dangerous shoal at the eastern end of the English Channel, probably was in the early Clristian conturies an island of soft rock which the sea wore away until is waves closed over the place where it had been. If the historic period of North America were as sreat as that of Furoluc, we should cloubtless have many instances of such ranished lands. As it is, we can see that many capes ancl isles on the northeastern shore of this continent are impending on destruction. No Man's l,and, a lonely island of glacial elrift on the Massachusetts shore, south of Martha's Vineyarl, is rapidly wasting before the attack of the stormy sea to which it is exposed; it seems likely that in less than a century this shred of land will have disappeared. The same is the case with Sable Island, near the entrance to the Gulf of Sit. Ifwrence, where the remmant of a mass of clébris left by the last slacial period, probably a portion of a frontal moraine, is rapidly siving way before the waves and currents which are carrying its sands to the neighboring derp sea. In fact, all such istands are liable to very rapid destruction, for the reason that the waves find less diffeulty in remoring the cébris than they do on the continental shores. Around an island of inconsiderable size the déloris is readily borne away by the strong curronts, and is guickly cast into decp water, so that it does not, for any considerable time, obstruct the work of the waves. ()n the long continental strands, howcver, the waste from yelding cliffs does not so easily escape from the shore; the sreater part of it is forced to creep along the coast-line until it passes from the district of cliffs, and finds its way into the pocket beaches. 
Before leaving the zone of the coast where the sea is working the cliff backward into land, we must not fail to consider the action of the tides on such a shore. We have alreatly noted some incidental effects of these singular morements of the ocean waters; we must now look upon their larger manifestations, and consider how they affect the processes of the shore. As is well known to the reader, the tidal mosement is clue to the attraction of the sun and moon upon the mass of the earth; in fact, every star in space pulls upon the earth; but the moon, because of its nearness, and the sun. because of its magnitude, and as compared to the fixed stars its relative propinquity to our sphere, pull with enough energy to raise the sea abore its prevailing level. The attractions of these bodies tend to divert the whole mass of the earth, and if it were completely fluid in its depths, as geologists once supposed, the sea and the land would alike rise in a low tidal wave, and we should perhaps notice no movement of the oceans. Because of certain features in this drawing action of sun and moon, there are two tides corresponding to each of the attracting bodies. If the earth were uniformly covered by a very deep ocean, one of these tides would be approximately under the sun or satellite, and the other on the opposite side of the earth. Owing, however, to the irregular form of the lands, these tidal waves have to chase around the earth, rushing up the narrow spaces between the lands, and so fall behind their due place. Moreover, because the solar and lunar tides are sometimes in the same place and sometimes far apart from each other, these two waves now and then (onjoin their volume and again oppose each other. The result is that the tides, though they have a certain regularity, are. as regards their rise and fall, rather irregular phenomena. 
Furthermore, they are more or less affected by the action of the wind; a heavy storm blowing off the shore will cause the tide to retreat farther and advance less far than when the wind is blowing violenily towarel the coast. These varying conclitions much affect the action of the ticlal waves on most coist-lines.

The form of every coast to which the tides find access very greatly affects the way in which they operate upon it. In the open sea the rise and fall of the ticle is slight, probably not exceeding a foot or fifteen inches. If the shores of the cointinents were straight shore walls parallel to each other, with the sea very deep at their bases, the ticlal swing would be no greater than it is in the middle of the great Southern ()cean : but, as we know, the coast abounds in re-entrant and salient angles, deep bays, and strong promontorics, and in this complication of paths which they open to the waters the tide is curiously affected. Wherever an ocean or bay opens a wide mouth to the entering tide and narrows its shores at the head of the re-entrant, the swift-running broad wave moving inward, usually at the rate of several hundred miles an hour, is compressed in the narrowing channel and forced to rise to a greater height than in the open sea. Thus in the North Atlantic, the shores of which converge toward the North Pole, the tide rolling up from the southern sea is constrained to rise to several times the height it had in the more open water. So, too, when a bay is more broad-mouthed and tapers to a sharp head, as is the case in the Bay of Fundy or the mouth of the Severn, the tidal wave is yet further constrained and forced up, it may be, to an elevation of fifty feet or more above the lowest level of the sea. Every considerable variation in the form of the shore has its effect upon the rise 
of the ticie. 'Thus in passing north from (ape Florida to the St. Lawrence, the well-trained student of the tides would be able to determine in a general way the shape of the shore by the rise and fall of the sea.

It is easy to conceive how the energy of the tidal currents

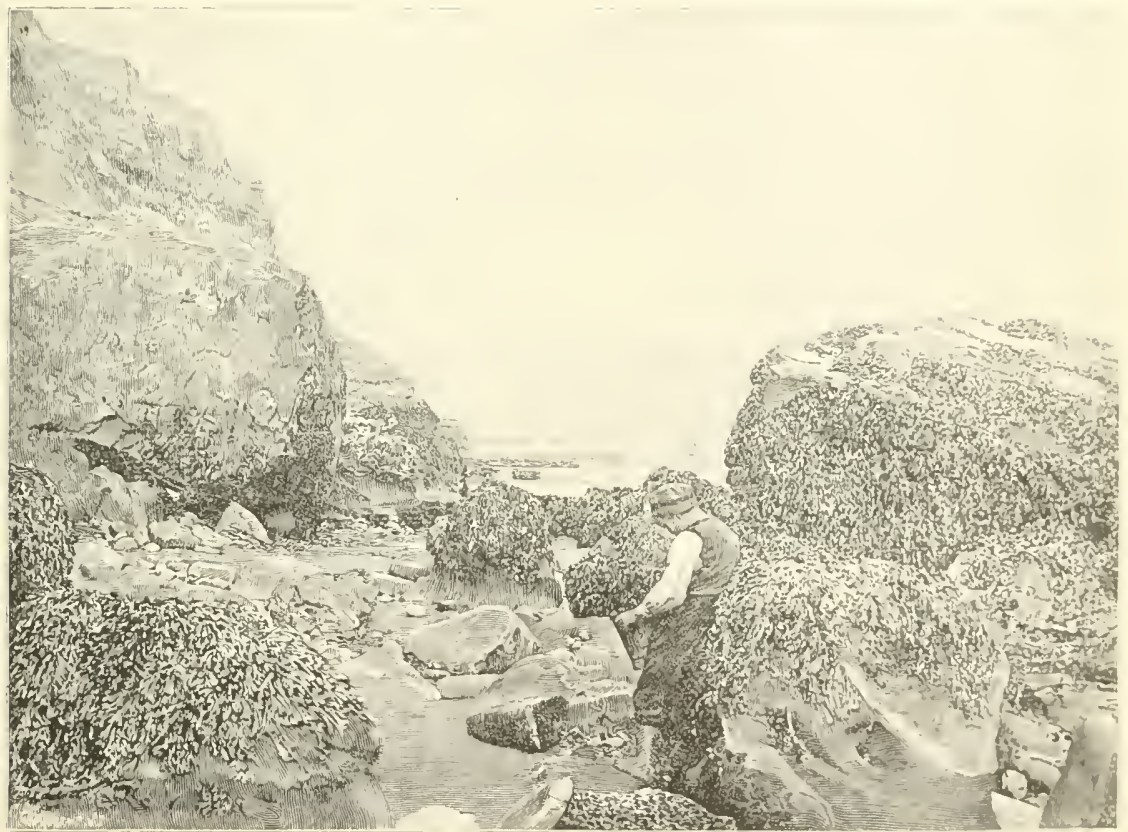

Seashore View

Showing the position of the mantle of sea-weed which protects the rocks from the action of frost and. 11 a measure. from the assaults of the waves. Note that the smaller fragments which may be tossed ahut are destitute of the covering. The lower portion of the stone in the foreground against which the bus is leaning shows the scouring action of the waves which they effect by means of the sand which they impel

depends, in the most intimate way, upon the altitule the wave attains in the diurnal morement. IVhen, as on the coast of Florida, the rise and fall is probably not on the average much more than one foot, we ma! lave but fecble movements created by the tidal swing: in the region about the Bay of Fundy, where the rise is fifty fect or more. 
the streams have a swiftness and energy comparable to those exhibited by the greater cataracts. The capacity of the tidal currents, like that of all streams, their power to scour and convey sediments, depends immediately on the speed with which they move. When, as on the eastern coast of Maine, they often flow at the rate of six or eight miles an hour, a speed nowhere attained by the waters of the Mississippi, they strip all the shores on which they impinge of all their fine detritus which may have accumulated there, and thus expose the rock to the effective action of the waves.

For the reason that these tidal currents are most energetic when they are confined as in a wedge-shaped bay, they exert their maximum influence not on the open coast, but in the recesses of the shorc. The waves of the ocean tend to force the detritus they have torn from the exposed part of the shore into every neighboring bay, thus in time destroying all the inlets and bringing the shore to a uniformity of outline; but where the sun and moon pull the waters about and send them whirling into the bays and harbors, the currents which are thereby produced scour out the sand, clay, and pebbles which the waves have imported into these recesses and remove them again into the open sea.

Along every continental shore, and often far into the interior of these great land masses, we may discern indications that the work which we now observe to be going on upon the coast-line has at various times been effected at levels far above the present plane of action. These ancient sea margins, as they are termed, have been noted by observers since the early part of this century. It is only, however, within the last fifty years that geologists have begun to attend to this class of phenomena. A careful study of such 
indications of ocean work at higher level is, indecd, about the last distinct step in geological inquiry.

At many points where the elevation of the land has recently occurred, as it often has in some slight measure since the beginning of recorded history, it is very casy to note the traces indicating the recent presence of the sea. There is the cliff, against which the waves broke, often with its accompanying caves, and chasms, and the beach slope frequently retains the semblance of its original character. But even in these monuments of sea-action, which may not be older than the Pyramids, the student observes that the change-bringing forces have often worked with such efficiency as in good part to destroy, or at least to confuse, the evidence. A talus has generally formed at the foot of the steep, which, with the falling in of the cavern roofs and the chasm sicles, has greatly modified the form of the strata. At the same time, the streams cutting through the beach line, have washed the friable materials to and fro so that the original regularity of the feature has been in good part lost. Observ. ing this rapid destruction of the marine monuments which are so conspicuously in evidence along the existing shore line, the student is prepared to find the indices of higher, and, therefore, more ancient shores become progressively and rapidly less clear as he ascends above the existing coast line. His anticipations will be more than realized, for he will find that the task of tracing sea margins of considerable elevation is one of surprising difficulties. He has, in fact, to trust rather to bits of evidence than to a massive presentation of the truth. He will not find the old borders of the land marked as he might expect them to be, by long straight benches, but rather hy fragments of the ancient shelves with here and there, perhaps, 
a ruined cave or chasm, or a few rolled pebbles, which have becin corereel, and thus protected from decay. by the talus of angular frasments, which weathering action has drawn down the cliffs. Here and there he may find his evielence reciuced to that which is affordecl by the existence of solitary steeps, which were evidently islands in the open sea. Thus, on the piedmont Jain, to the east of the blue Ridge in Virginia and the Carolinas, there are occasional detached elevations, rising as hills or mountains from the level country, the origin of which, on account of the steep faces of these elevations and the nature of the accumulations at their base, we have to believe to have been due to the fact that they were, in no very ancient day, islands lying off a shore which lay to the westwarcl. It may be noted in passing, that such detached islands are often sared from destruction by the fact that the waves and currents keep their bases free of pebbles and thus remore the agents which, as we have seen, serve to batter the bases of the cliffs.

It is casy to see that the effacement of the ancient indications of marine work depends upon the constant downwearing of the land, which is brought about by the agency of sub-ä̈rial decay, by the action of frost, and by the movements of water in streams or slaciers. Although the amount of this down-wearing is variable, it probably amounts to an arerayc of a foot in from three to six thousand years, so that in a million years, not a long term in the geological sense, the land surface descends some hundred feet, or enough to take away all the indices of an ordinary shore life. The fact that such an escarpment had an original bold relief, would be linely to cause the process of decay along its line to be much accelerated. IVe, therefore, cannot expect this kind of record 
of the land outlines of ancient days to be traceable in the remote past.

There is, however, a way in which sea shores, eren those of very ancient times, may be prescrved and revealed tor our - time. This occurs, where, in place of the land rising in the continental oscillations, it sinks, so that the shore line becomes submerged. In this case, when the indices of the submerured shore are not destroyed as they pass through the mill of the surf, they may be buried beneath stratified deposits. which may accumulate to any thickness. When the regrion is ayain elevated and the rocks brought abore sea level, erosion may disclose to us the marks of an old shore line preserved in an excellent shape for ready determination.

It is well for the student to associate in his unclerstanding the joint work of marine and atmospheric agents in wearing away the land. He will thus see, in his mind's cye, the two great agents of degradation in their coöperative work, and he will be prepared to interpret some of the most interesting features which the continents exhibit.

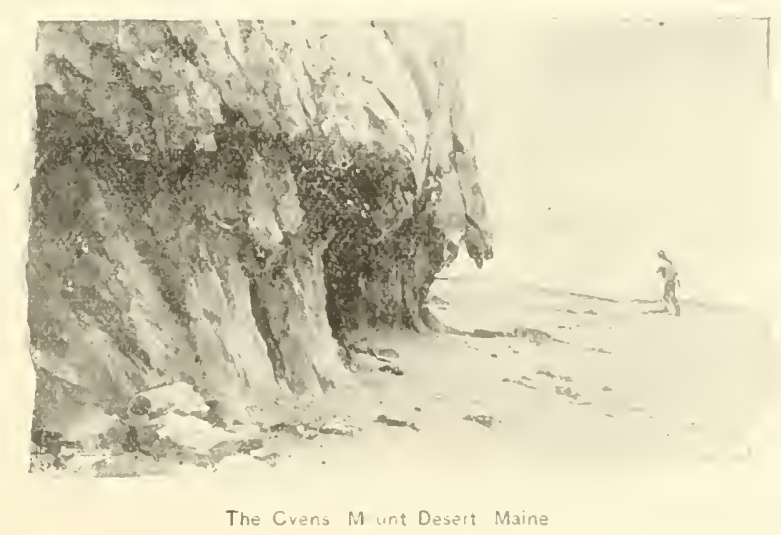




\section{SEA-BEACHES}

Various Divisions of Shore-line.- Symmetry of Sea-licaches.-Action of Surf.-Rate of

Wear of letritus.-Action of ('oast Currents.-Sand l)unes.-l'ocket-lieaches.-

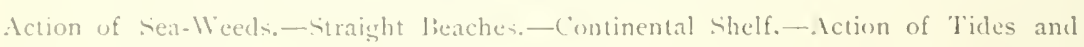
Waves-Variations in level of Shores.-Formation of Jagoons. - Manne Marshes: Their Igricultural Value.-Endurance of Sand: Effect in l'rotecting the continents.

THERs: are two great divisions of the shore-line which even the cursory observer quickly learns to recognize; these are the cliffs and the beaches. In the cliff section he easily perceives that the sea is gaining on the land. The conditions under which the ocean extends its empire afford, as we have already seen, a beautiful subject for inquiry. We have now to turn to the parts of the coast where the sea spends its energies, not on rocky steeps, but on the softer-yet really more resisting-barriers of sand. Below the frowning walls, formed where the surges are effectively assailing the land, we find generally a wide slope where the breakers are continually at work grinding the stone they have rent from the cliff into small bits. Usually, however, this incline is made up of large, bowleler-like masses, with a few small pebbles and a little sand packed into their interstices. We readily see that the greater part of the fine stuff into which the waste from the cliff is ground journeys with the currents, which the storms and tides produce, to some point where it is built into sand or pebble beaches. In this migration the pebbles move along next the shore, in the shallow water where the waves 
and currents are strongest, while the sand often travels in the deeper water at some distance from the shore-line. They both commonly arrive in the end at some characteristic beach where they enter on another chapter in their singular history.

In begrinning our study of beaches, it will be well to choose some part of the shore where the cliff district has an

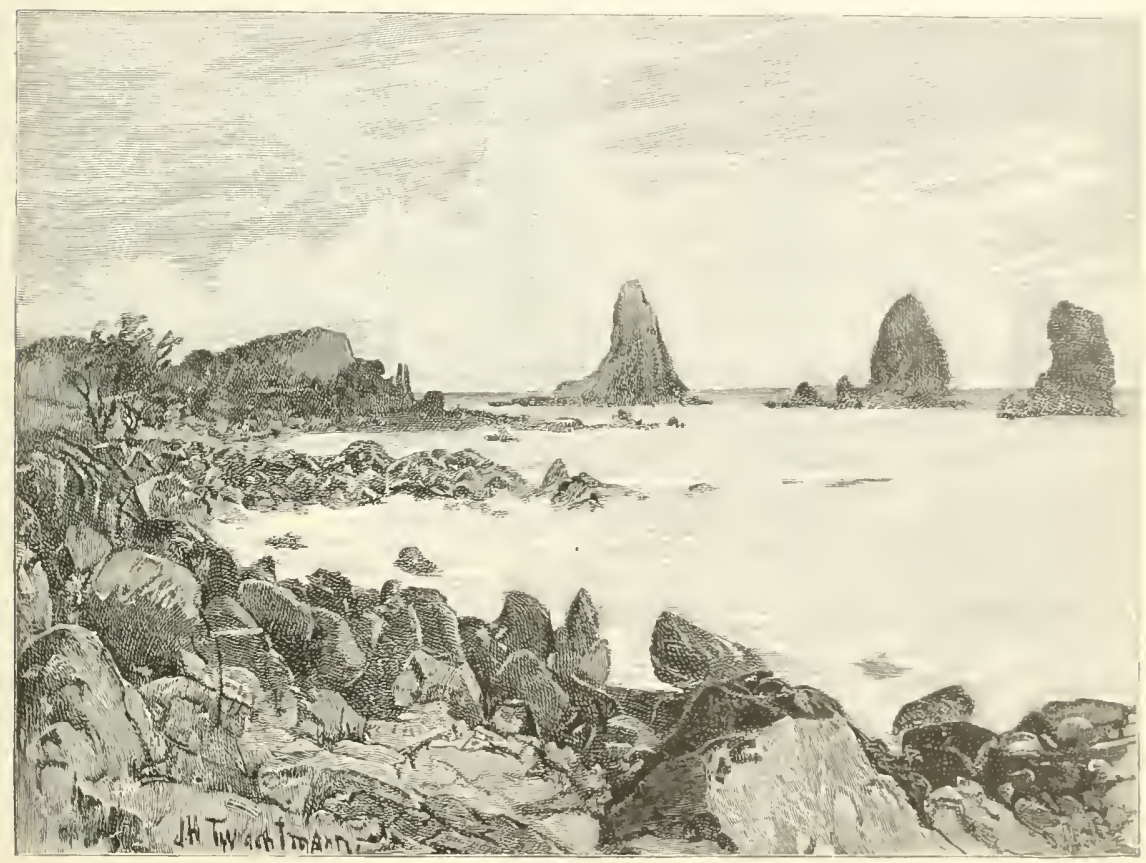

The Isles of the Cyclops, near Catania, Sicily

Showing the extremity of a lavil stream much carved by the sea. The bowlders in the foreground and middle distance constitute a nätural sand factory.

irregular front, exposing bold headlands to the free assault of the waves, while near by there are embayed recesses intu which the detritus, in the form of pebbles, can be impounded. like the balls in the pockets of the old-fashioned billiard table. An ideal exhibition of these conditions is given in the illustrations of this chapter. It will be seen that the waves and 
Where currents necessarily import the larger part of the dibris they rend from the promontories into the recesses of these b.jys. Places where a study of the results of these conditions maty be made can be found along almost any mile of shore, from New York city to Greenland, where hard rocks face the sea. It is rare, indeed, on every cliff shore that we have to search for as much as five miles along the coast without finding one of these pocket-beaches, whereto the rocky matter from the neighboring precipices swiftly journeys to underese the last stage of its destruction.

To the naturalist's cye the most striking feature of the pelble beaches in the symmetry of their form. This is so characteristic that every one, however little trained in the methods of interrogating nature, is sure to observe it, provicled he follows the path which leads him from the rude cliff shore to these more aracious outlines of the beaches. ()n the steeps, where the sea is eating into the land, all the outlines are ragged; the scenery has the hard, irregular quality which belongs to all fields where the destructive influences of nature preponderate over the forces which build up or renew. On the true beaches the gentle and harmonious curves attest the constructive order of the actions. They have the peculiar grace which marks all things which grow, their form is truly vital. W'e note the delicate finish of the curve of the line of contact between the water and the land, and the equal symmetry of that which extends from deep water to the crest whereon stands the sea-wall and perhaps the attendant dunes. However much the eye and the mind may for a time enjoy the stern scenery of a rock-bound coast, we turn with abiding satisfaction to the quiet beauty of these more perfectly organized shores. They are like calm weather 
after a storm, which, however well we may enjoy the tempest, is the more grateful to cur senses. We may visit the rude scenes of the besieged cliffs with the grim pleasure with which one may behold a battle-field, but that is not the place where one would dwell if he seeks harmonies and the peace which comes with them. If one would abide by the sea, it is better to seek a home by the beaches.

At first sight even the most beautiful beach is likely to seem, to those who are uneducated in the study of the shore, to be rather monotonous and devoid of interesting features. The smooth outlines of the scene suggrest in themselves a simplicity in the conditions which, we shall find, does not exist. In fact, these even shores present a greater array of actions, and afford the student a larger field of profitable inquiry, than he has found in the apparently more varied rock coast. It is because all the conditions of the geologic life which lead to their growth and maintenance are perfectly adjusted to each other, that the well-organized beaches appear so simple. They are like the living forms of animals and plants, where the shapely exterior hides the complicated anatomy and the marvellously delicate adjustment of varying and interesting functions, so that the creature seems to need no explanation. This is not a vain analogy, for, as we quickly see when we make a detailed study of any beach, it is in many ways a highly organized structure.

The best way to begin the study of these portions of the strand is to select some small and pebbly pocket-beach ncar a cliff section whence comes a plentiful supply of dibris worn from the bed-rocks by the action of the waves. At the horn or extremity of the beach, next these cliffs, we may often find bowlders roughly rounded by the rude mill of the surf 
to the spherical form, and of great size; they are sometimes two or three fect in diameter. We can, in times of heavy storm, see that the surges roll these masses over and against each other, and we note their constant wearing as they journey onwarel, not only in the sound of their clashing, but also in the steady climinution in their size as they go farther away from their place of origin. Near the points of the crescent shore these rolling stones are more exposed to the action of the waves than they are as they slowly creep down into the curved bay, so that, notwithstanding their weight, they are ground against each other and consequently diminished in bulk. As we follow them toward the centre of the crescent, we observe that they constantly become smaller, until, a mile or two away from the point where they escape from the cliff section, they may be no larger than billiard-balls. If the beach be very extended, the central portion of its front may be composed of fine sand, the pebbles having been ground to clust in the powerful attrition of the waves. IV thus arrive at the first and most important point in the history of these pocket-beaches, and see that they are mills which serve to srind up the rocky matter torn from the cliffs, and that they bring it to the fincly divided state in which it can easily be taken by the marine currents to great distances. We must now proceed to see the details of this admirable mechanism of the rock-grinding mill.

When the ocean is in its ordinary summer state of stillness, with only the light pulsation which sends a few times a minute a litule breaker against the beach, we find that only the sand and smaller pebbles are stirred by the motion of the water; but now and then, even in this peaceful time of the year, storms send in more powerful surges. These may come 
from a wind which blows directly upon the shore, or from some storm in the open sea so far away that the ground-swell alone attests its passage over the waters. These waves may roll upon the beach with a height of from five to ten feet, and at the rate of from four to six strokes a minute, each blow applying to the shore-line in a mile of its length eneryy which is to be measured by thousands of horse-power. These surges break or overturn, not at the very shore-line, but at a distance from the dry sands determined by their altitude and the shape of the beach. On ordinary fronts of sand they tumble into surf-waves, a hunctred yards or more from the point where we may stand dry-shod, and on many parts of the coast they break at a mile or more from the water-line. Within the outer line of surf the waves gather again and again to form lesser breakers, so that there is a wide belt of tumbling water extending, it may be, for hundreds of miles along the coast.

Next the shore this turmoil of the sea is marked by fierece splashings arising from the overturning waves; the water rushes up and down the steeper slope of the inner part of the beach, sweeping the coarse sand and pebbles before it in each movement, it may be for sixty feet or more. If the pebbles are abundant, we can easily hear the dull, srating sound arising from the friction of the stones against each other as they are driven to and fro. Standing with bareel feet in this splash, we easily note the fact that it is not only: the surface of the beach which is moved, but the mass, to the depth of perhaps a foot or more, partakes of the morement which the suroing waters impress upon it. The stoncs are ground against each other, and the sand among them pulverized as if between mill-stones. The result is that at each 
swaying of the mass a consiclerable amount of rocky matter is made into fine mud. which is free to drift away in the whirliner waters. $11 \mathrm{e}$ mily often see that the sea-water is perceptibly mudelied by this action for a considerable distance from the shore, a wide fringe of the sea attesting by its turbidity"the work of this mill. If the student be an expert surfbather, he may renture beyond the shore belt to the point where the waves topple orer in the breakers. There he wiil discurer another mode of action of the waves, which differs in many resarels from that brought about by the swayings ayainst the shore. When the wave topples over, the upper part of its mass falls down, it may be from the height of ten fect, upon the bottom. on which it strikes with wreat energy. If this Hoor of the sea be fine sand, the effect of the blow is slight, and the particles are little disturbed, being trodden to a firm mass by the lons-continued tramping of the surges. If, however. the bottom be composed of pebbles, with their faces male slippery from the water or the gelatinous ooze of the seatloor, they Hy about when the falling ware strikes them, siving forth a hoarse roar from their friction against each other. Sometimes we may observe how these swiftmoring stones striking agrainst a firm-set bowlder skip into the air like a ball from a bowler's hand. So we see that there are two kinds of rock-grinding done on the beach-that which is accomplished next the land by the swinging movement of the wares and that which is effected by the breakers.

The rate at which the pebbles are reduced to sand and mud by these processes of the beach raries, of course, with the hardness of the materials and the energy with which the waves assail them. $11 \mathrm{e}$ may judge the speed of this work not only by the rapid reduction in the size of the pebbles as 
they pursue their devious way down the coast, but by many other even more instructive cxamples of this work. It not infrequently happens that ressels loaded with brich, cral, irron ores, and other hard substances are cast amay on the cexpresed beaches of the Atlantic ()cean, and their cargoes delivered is the shore waves. In a few months we find the waste scat-

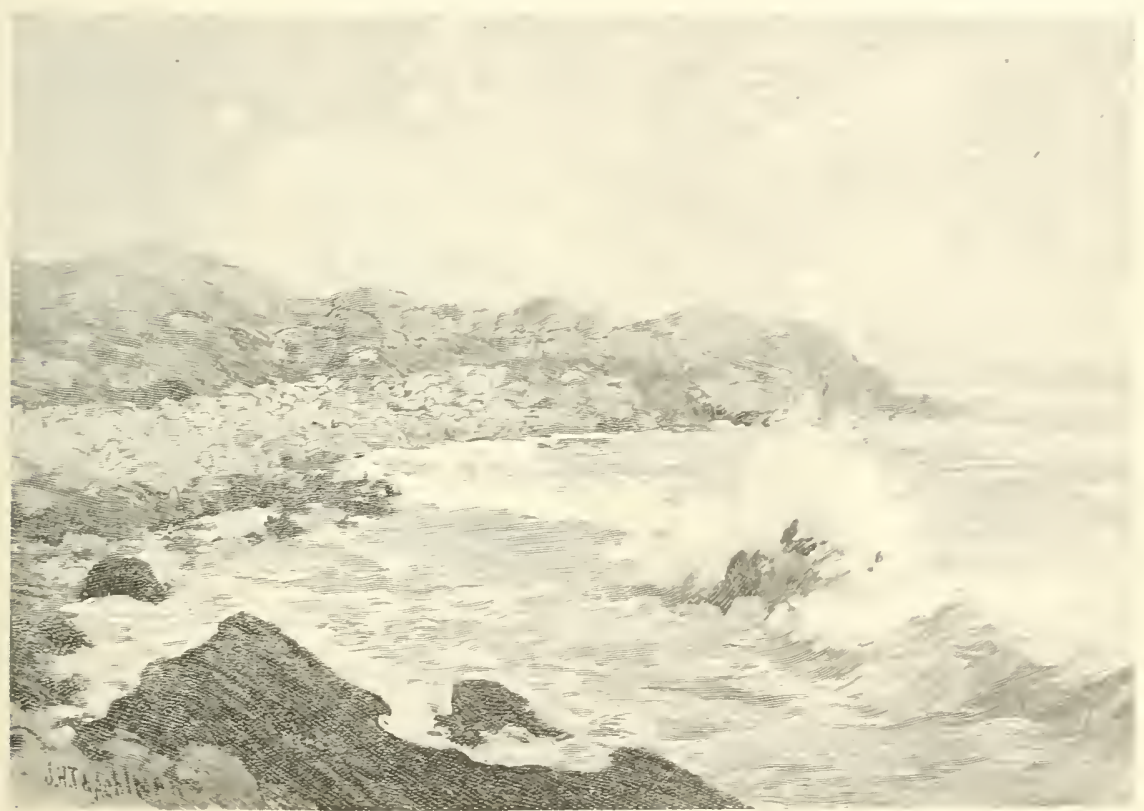

Easte. S de f Cape ir. Matuact. se:

Bowlder beach of the rudest type, showing large stores plucked from the neighb ring o ast. which ...T beaton against each other when heary surges roll against the shore.

tered, it may be for miles, in the direction in which the materials of the beach are moving. In some cases hart-burned brick or anthracite coa! will journey on a sand beach for distance of five miles before the bits are entirely worn cut. and they may endure for a year before they are quite round to dust. If the shore be pebbly and well exposed to the sea. all the fragments, save those which find protection in some 
sheltered place, will commonly be destroyed within a mile of the point where they were first exposed to the surf action. On the eastern face of Cape Ann, where exceedingly hard fragments of wranite the waste rock from the quarrieshave been cast into the sea, it requires several years for a frasment the size of a nail-kers to be rounded into the spheroidal form so characteristic of marine erosion. Slow as this wearing may seem, we must remember that, measured against the geolosic ages, it is indeed exceedingly swift.

It will readily be seen that a portion of the beach, that which is above the limit of the sea except in times of high tide and great storms, rises more stecply than the portion which is below the sweep of the water; in fact, the line from the shallow water to the crest of the beach is like one-half of a catenary curve, or the shape in which a chain or rope hangs when it is suspended between two elevated points. Such a curve is, as we casily recall, nearly flat in the middle and rises steeply near the support. This shapely form is due to the action of the waves, which continually thrust or heave the sand and grasel against the shore. The effect of this urgence is modified by the continued reflux of the waves; in their backward morement they cary away the greater part of what they have brought in. In a short time an equation is determined between the incoming and outgoing of the detritus, and so the sea-shores of all the world establish the same rate of slope for like conditions. In times of storm the slope may, for a little while, be brought to a greater declivity, but the waves, moderating in violence, proceed to drag away a part of the detritus and soon restore the declivity to its normal condition.

When a storm has blown obliquely upon the shore, so that 
it has produced a strong current in one direction, the buach in its upper parts will rapidly waste away, but a change of current will quickly restore the usual outline. ()n some coasts, however, there is a steady current in one direction, so that the beach would quickly disappear were it not for the constant accession of sands which march down the coast or are brought in from the deeper sea. Thus on the southern coast of the United States from Cape Ilatteras to Cape Florida, particularly along the shore of the Floricla penirsula. the sands are journeying toward the south under the influence of the prevailing current, which sets in that direction on the landward side of the Gulf Stream. From Cape Canareral toward the coral-reef section of this shore, the coast current is so strongr that the beach is much scoured away, and has a slope which is often fifteen degrees of declivity between high and low tide mark. The unhappy footman who has to toil along this desert strip of sand finds it almost impossible to make a day's journey of twenty miles without exhaustion. The grains of ever-shifting sand are so incoherent that the foot sinks cleep into the mass, and the unequal position of the feet racks the walker in a painful way. I remember a walk of sixty miles along this shore, from Biscayne Bay to Jupiter Inlet, as among the most trying inciclents in my field experience. The extended sand shores differ in certain important ways from the smaller pocket-beaches, which still deserve our attention. Along the water-washed portion of these strands we find that the beach suddenly changes its character. Below the level of high tide it is excecelingly shapely; all of its contours are very regular, and present little else than a gentle, uniform slope toward the waves which give it form. Where the waves do not act, the contours at 
once become rude, and, when first and imperfectly seen, apparently shapeless.

$11 \mathrm{e}$ commonly find on pebbly beaches a rude wall of water-worn stones, rising, it may he, ten feet or more above high tide. This wall sweeps around the crescent of the true beach, following its course from one end to the other, looking often like an artificial rampart. Now and then it is cleeply breached or sometimes for a considerable distance swept away. The origin of this beach-wall is simple: in times of unusually heary storms blowing directly upon the coast, especially when they fall in the scason of the highest tides, the waves trespass upon the upper part of the shore and fling a great quantity of pebbles before their swift-moving fronc; when the on-rushing surge conveys these pebbles beyond the seaward face of the beach to the crest of its wall, they fall upon the more level summit, and the retreating waters cannot drag them back into the sea. When the ocean is in its stormiest contition, the pebbles may be tossed over the crest of the emoankment and fall down its landward slope. If the seas struck the shore in a uniform manner, this wall would have a perfectly regular height; but now and then, in great tempests, there comes a vast wave, which has gathered unto itself the strength of scveral breakers, and which may assail a part of the sea-wall with such fury, that it breaks it away and sends the dicbris into a steep, delta-like fan out upon the lowland behind the elevation. Subsequent waves, which may be of less volume, pour through and decpen the breach, so that the wall acpuires its crenellated or battlemented aspect. The open structure of the pebbly mass allows the sirash of the wave to penetrate downward and escape slowly to the sea, so that the retiring water is diminished in volume, and its 
ability to drag the stones backward down the slope is less than its forward thrusting power; thus the pebbly sea-walls are much steeper-faced than those of sand.

The wave-made embankments on the sandy beaches differ in their form and in the conditions of their construction from those which are made up of pebbles. The sand,

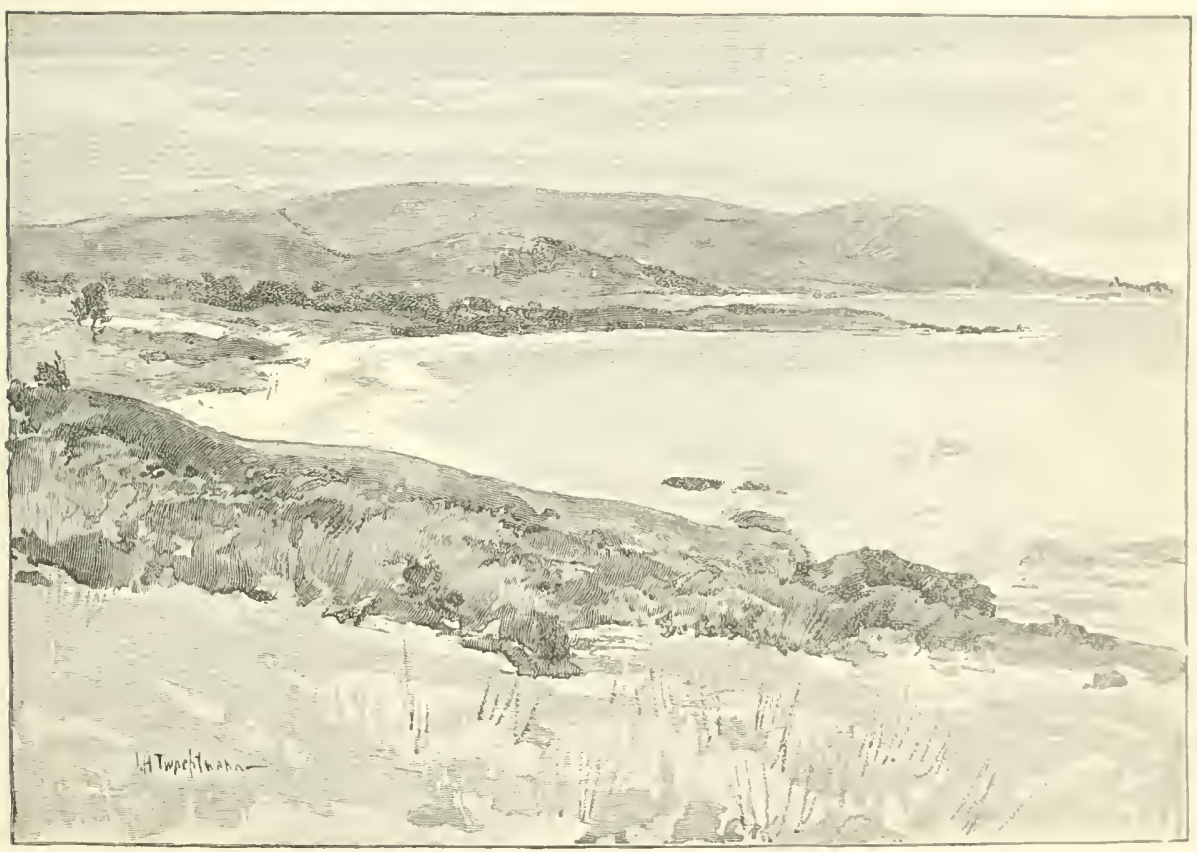

Carmel Beach, Calıfornia

Showing extensive sand flat with slight dunes above the water level. The foreground also shows traces of blown sand partly imprisoned by herbage.

owing to the fineness of its grains, is easily blown about by the wind. When the tide retires, a broad expanse of this material is left for some hours exposed to the sun. The surface dries, and the gales from the sea sweep the particles up the slope until they arrive at the crest-wall; here they are often caught in the tangle of beach grasses, and other plants 
Which Hourish in arenaceous soils, and in the close-set leaves and stems, and are protected from the currents of air. IVhere the movement of sand is most rapid, it may bury these plaints out of sight, but most of them are tolerant of this submersion and quickly grow upward and make a new entanglement for the moving grains. In this manner the crest of the beach grows upward in an irregular manner, its crown bearing a range of hummocky sand-hills which often rise fifty feet or more above their base, and in farorable situations may attain a height of two hundred fect.

The dunes, as they are termed, are less abundant on the beaches of the Atlantic coast than in many other parts of the seaboard, for the reason that the prevailing winds of that region are from the west; and the sand swept up from the sea-margin is, to a great extent, carried back by the off-shore winds; even the scanty dunes of our shore would hardly exist were it not for the fact that the vegetation on the land side of the elevations is generally quite luxuriant and holds the sand which has been brought to its protection from the shore. The most characteristic dunes of our sea-coast are found where there is a stretch of shore which, by some irregularity of the coast, is exposed to the sweep of the western winds. Thus the seaward extremity of Cape Cod is largely macle up of wind-blown sands. So, too, the long stretch of shore tending to the southeastward from Portsmouth, N. H., to the mouth of the Annisquam ticlal river in Massachusetts, yiclds to the northwest winds a good deal of sand, which is carried down to the great dunes of the Essex district on the mainland. "The Banks" of North Carolina, fifteen to twenty-fire miles distant from the mainland enclosing the 


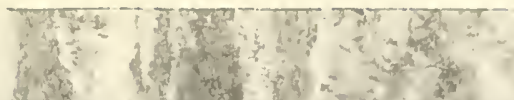

bis

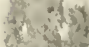

Hit

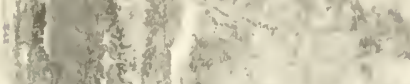

+1 .

1दि.

tas

finety

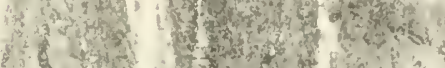

$\beta^{2}+x^{3}$

की

1.

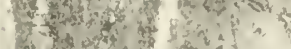

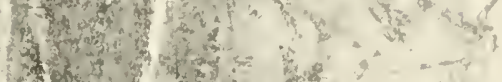

5.

管事

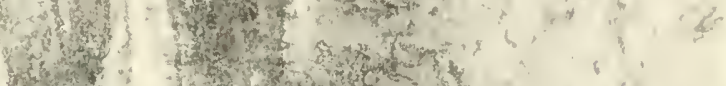

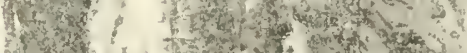

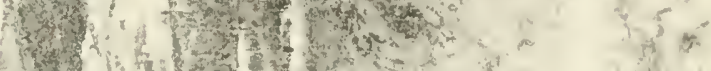

(1)

cositit

aid in.

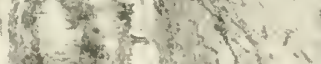

(x)

(1) 4 (1)

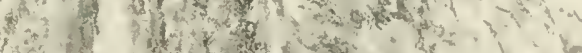

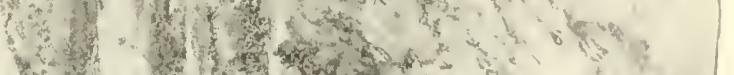

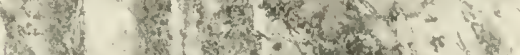

is

(it)

$\because>19$

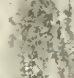

स.

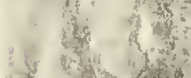

(2) y.

$$
\text { (3) }
$$
(3) 1. $x^{2}$.

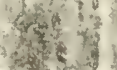

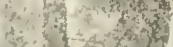

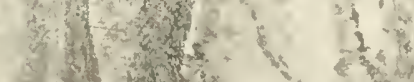

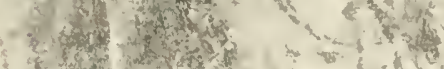

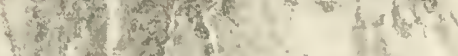

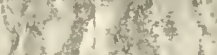

if 2 the

m.

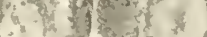

$+\quad 11$ ?

i- $15 x^{2}-\frac{1}{5}$

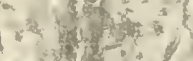

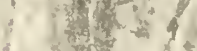

1. $610=12$

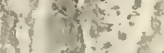

- inc

i. 3 in

\&. 1517
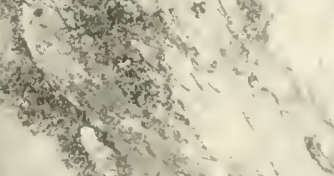

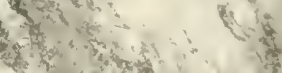

(3) the का का ?

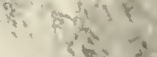



waters of Pamlico Sound, afford another excelient example of such dunes.

In this country the greatest dune districts are found about the southern end of Lake Michigan, where an abundance of sand of glacial origin is swept upon the shores in times of storm, and is borne away by the winds. I3ut if the stuchent of these features would find them at their best he should risit the dunes of eastern England or those about the head of the Bay of Biscay, where these masses of sand not only grow to a great height, but frequently separate themselves from the shore and slowly march as moving hills to great distances inland. Thus in Britain one of these dunes in the last century invaded the village of Eccles, and buried the dwellings and the parish church so that even the top of the spire was hidden. After a number of years the summit of the church began to reappear on the leeward side of the hill, and in time the remote descendants of the dispossessed people may be restored to their heritage. In the Biscayan lands the incursions of the sand have proved so menacing to the fertile fields of that country that the government has expended latrere sums of money in order to root the invading dunes to their places. The spectacle of these wandering masses of the friable portions of the earth's crust shows us how great is the effect of the plants in restraining the action of the wincls. Where, as in the great deserts, the soil is too arid to maintain vegetation, the finely divided portions of the rock, which the plants convert into soil, are at the mercy of the air. and are set upon endless marches, which often alter the neighboring fertiie districts to the state of the Sahara.

The way in which these hills of sand march is very simple. On the windward side the hill is scoured away by the blasts, 
which are the stronger because of the exposed position of the slope. The sand whirls over the crest and falls into the lea, where it is caught and fixed by the vergetation so that the less powerful winds which assail it on that side cannot stir it from its position. This process repeated may advance the clune into the interior at the rate of several feet a year. For a time it receives constant accretions of material from the neighboring shore; but as it departs from the coast these contributions become less in quantity" generally another dune forms behind the first of the train, and absorbs all the sand which is blown from the beach. As the moving mass passes into the interior it usually becomes ever more and more coated by vegetation, for the reason that it comes into a region where a greater variety of plants can dwell than upon the shore-lands; moreover the sand becomes decayed, tends to cement into a firmer shape, and provides more nutrition for the growth of regetation. Thus in time the clune is brought into the state of an immovable hill, becomes grass or forest clad, and only rarely and to the trained eye reveals its curious origin.

On the small islands which frequently border the shores of the great lands in the manner in which they are distributed along the northern coast of the United States, beaches are rare. Only here and there do we find points where the softer character of the shore materials has permitted the sea to form an indentation into which the waste from the neighboring shores is driven by the waves, and there retained until the movement impressed on the fragments by the surges has sround them to powder, which the undertow and other currents can carry out to sea. The result is, that the greater part of the waste from island shores is likely to be carried 
across the intervening shallow sea to the margin of the mainland. On the more extended coasts of such manlands, these indentations which catch the waste of the shores, and which we may for convenience term pocket-beaches, are, wherever the rocks are of varied hardness, of very common occurrence.

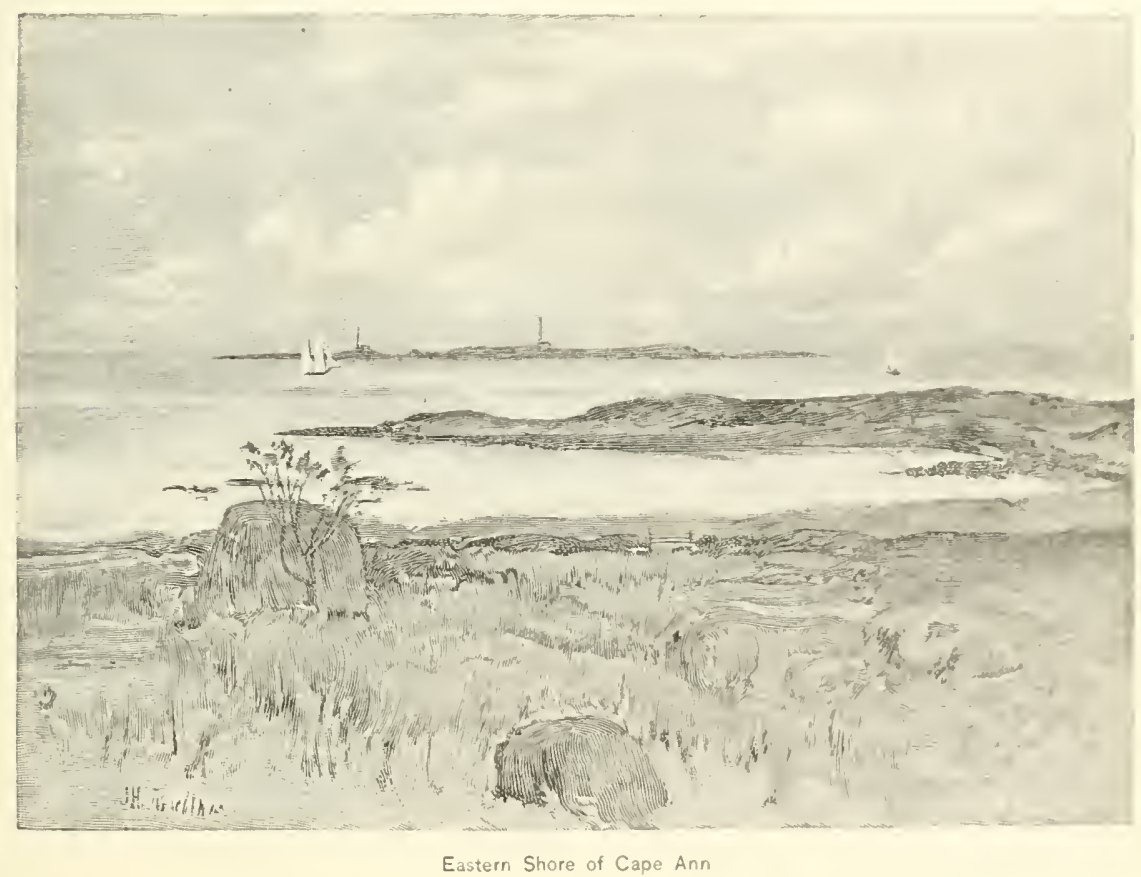

Showing small re-entrant with pocket-beach. Thatcher's Island in the distance.

Along the rocky shore of New England they are to be numbered by the thousand.

If, after studying the phenomena exhibited by any characteristic pocket-beach, the student will compare the form of a number of them, he will see that they-while agreeing in all the general features which we have already considered differ much in certain important details of form. The most striking variation is in the measure of the incurve which 
they present to the sea. Most commonly they are crescentic in their outline, like the slenderest sickle of the new moon, but they vary from this deeply re-entrant form through all the stages in which we may trace the filling of the lunar cup until there is scarce a perceptible hollow left. When the beach is newly formed it is always much curved; if it has lost this shape we can easily note the fact that it is by the progressive heaping up of the pebbles or sand in the central part of the bay. If the supply of dibris which is imported into the beach is greater than the wave action which there takes place can reluce to fine clust to be carried away by the currents, then the basin fills and the shore line becomes straighter. If the waves at any time grind up more detritus than is supplied to them, the shore is worn backward into the land, and the beach may, if the process continue long enough, utterly disappear. There is, however, as is the case in so many natural forces, a beautiful principle of compensation by which the several actions counterbalance or check each other. Thus, when a beach is ill supplied with detritus, and its curve becomes deeper, the waves which roll into it have a longer journey orer the shallow bottom, are diminished in energy, and are less effective in their work. On the other hand, when the beach advances on the sea for any considerable distance the waves encounter less friction over the shallows and operate with far more power. In this manner the ill-fed beaches soon arrange their form so as to grind up less rocky matter, and those which are gorged with pebbles consume it more rapidly.

There are many other noteworthy features in the pebbly beaches, only a few of which can be considered in this essay, for they are matters of detail, and, however interesting, have 
little bearing on the large problems we have to consider. We have already remarked the fact that the supply of these mills in which pebbles are ground to mud comes in the main from the neighboring cliffs. On the north Atlantic coast, and generally in all glaciated districts, a large part of these pebbles are from points where the sea is assailing the easily' worn deposits of bowlders which were so plentifully accumulated in the ice-time. Besides these waste materials on the land, there is a large amount of the same kind of rubbish on the floor of the sea, and much of it finds its way to the shore in the following described manner: All along these shores sea-weeds abound; from the level of mean tide down to a few fathoms' depth the rock-weed thrives, and in decper water, even to near one hundred fathoms of sea, the great laminaria, or "devil's apron," grows wherever it can find secure foothold. Sometimes these plants attach themselves by their root-like bases-which are not in fact roots, for they serve only for support-to shells which lie prone or are fixed upon the bottom. More commonly they adhere to a pebble left on the sea-floor by the melting glacial sheet, or drifted out in the "pan-ice" which in winter forms along the seamargins.

All these sea-weeds have floats which hold them upright in the water, and as they increase in size, they pull on their bases with constantly augmenting force. As the waves roll over them they increase the tugging action, until finaliy, in some time of storm, the plant lifts the stone from its bect and floats it in the water, buoyed up by the vesicles of air contained in its fronds. The plant and the uptorn stone are together borne in by the heave of the sea onto the shore. Coming into the breakers, the weed is quickly beaten to 
pieces, and the pebble enters the mill where so many of its fellow's have met their fate. The close observer after a storm may find any number of these bowlders along a pebbly shore which still show a trace of the sea-weeds which bore them to the coast. Wading out to near the breakers, he can often see these sea-weeds with their attached pebbles-sometimes as lare as a man's head-poised in the wave the moment when it rises for the overturning which makes the surf. On a (quarter of a mile of the Marblehead beach I have estimated that as much as ten tons of these seaweed-borne pebbles camc ashore in a single storm. Many of the beaches, which are so inadequately provided with pebbles from the neighborin shores where the waves are attacking the firm land that they could not be maintained from that source alone, are sufficiently fed by the means of supply afforded through the action of marine plants. *

It follows, from what has been above said, that the movement of coastal detritus is easily accomplished on straight beaches, such as are characteristic of the southern portion of the United States, but is very limited in amount on the rockbordered shores. Thus, while on the coast of Maine waveworn pebbles are rarely carried for a distance of more than a

* On the parts of the shore where the land has been extensively occupied by summer residents, the owners have in many cases protected the coast from erosion by embankments and sea-walls, thus diminishing the amount of débris which was formerly contributed to the pocket-beaches. In these artificial conditions the beaches often wear out, and the sea begins to assail the part of the coast which was once well protected. In such cases the only way in which the erosion can effectively be corrected is by carting each year to the beach a sufficient quantity of large bowlders to grive employment to the waves and prevent their encroachment upon the shore. The larger these bowlders, the better; for if they are of small size they will be tossed about by slight storms and rapidly wear out, while masses weighing half a ton will be stirred only by the more tumultuous seas. 
mile, we find at Cape Florida old and rounded srains of sand, worn out by a journey which they have macle from hundreds of miles to the northward.

The studious observer of the shore must often have noticed that when the section between high and low water mark is composed of pebbles, as is the case with nearly all the pocket-beaches, the bits of stone are generally arranged in successive ridges, the crests of which lie at right angles with the shore and rise perhaps a foot above the gencral plane of the beach, the intermediate bays having a breadth of a score or more feet. Where these ridges and furrows are well developed, the whole shore-line may have a curious scalloped aspect. The origin of these peculiar structures is not easily accounted for; to attain the explanation we should note certain evident facts concerning them. In the first place they are extremely impermanent. By placing a mark in the centre of one of the elevations, we easily find that they change their position with almost every storm. Sometimes, indeed, when the currents which move along the shore are very strong, they may entirely disappear, to be rebuilt in a few hours in another time of high wares. If we smooth them away with a shovel, we may see them reconstructed before our eyes.

The way in which these pebbles are brought into this order seems to be as follows, viz.: The crests of the billows which form the breakers do not tumble down at the same moment along any extended line. A glance at them shows us that at every few feet of their length the surge falls to the beach at a different instant. Hence the swash-ware, which slips up the beach, has an extremely irregular front; it ascends not as a straight line, but in separate broad tongues 
of water which are impelled by the extremely varied currents which the irregrular falling of the surf and the inequalities of the bottom bring about. If the beach is smooth when these tongues of water begin to swecp up its slope, they at once carve out shallow, indistinct grooves. The very front of the

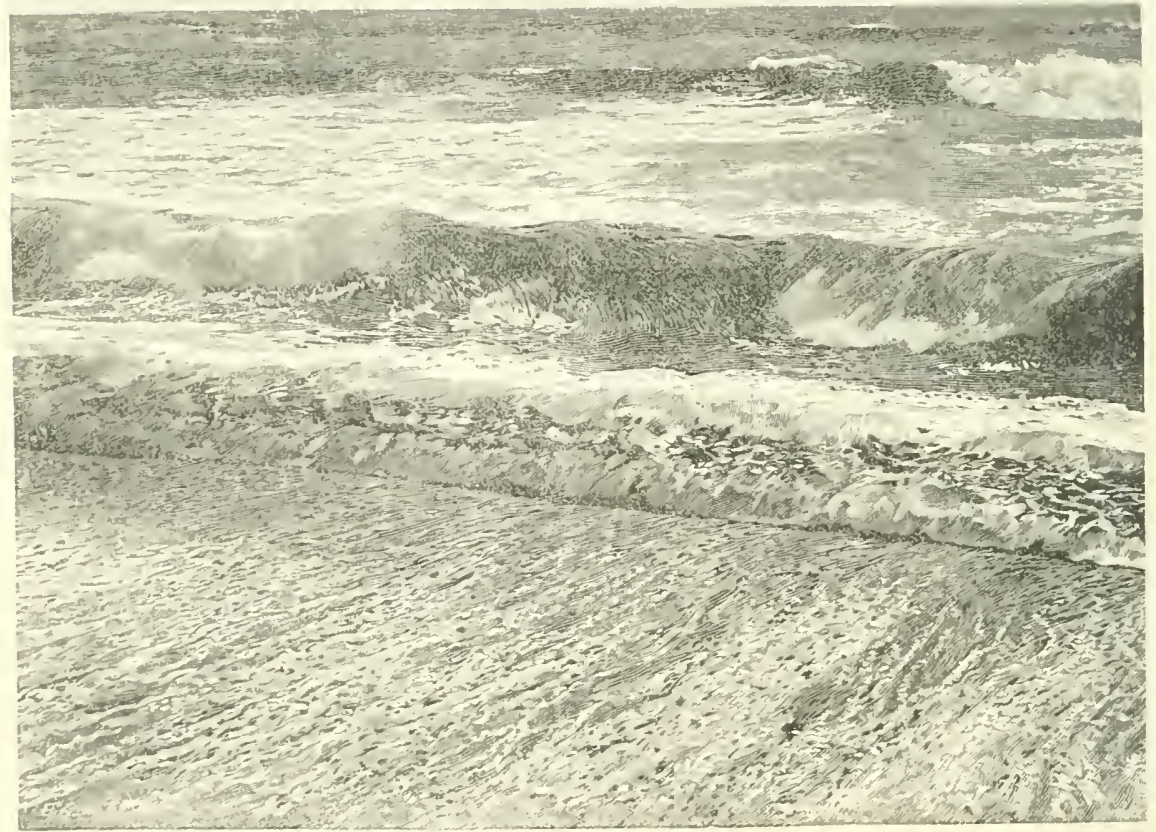

Heavy Surges on Beach Shore

Showing succes ive lines of advancing breakers and the process of retreat of a surge which has broken upon the shore. The parallel lines on the strand represent the swash swiftly flowing down the slope, dragging the sands and rebbles with it.

swash-flow makes the beginning of an indentation, and each successive morement extends the depression. In the middle of the re-entrant the current is strongest, because it has the freest play; in the reflux movement it scours out the dibris which on the sides is left untouched; and, indeed, 
the sicles receive a certain amount of material which the current brought with it, but which the retiring water, slipping between the pebbles, cannot take away. In this manner the little bays grow, cutting deeper into the beach at their heads and extending their horns farther out, until these projections come to the point where the inner lines of breakers beat them down. Each of these small divisions of the shore accumulations is in effect of itself a small beach, but it is peculiar in the fact that it is the product of the swash and not of the breakers.

The numerous pocket-beaches of our cliff shores have a very important influence on the history of the harbors, on which man's relation to the sea so immediately depends. Owing to the migration of the sand and pebbles along the shore, the greater part of this debris would soon find its way into the inlets which afford shelter for ships, and would shallow the anchorage grounds, or entirely efface them, were it not that the material is caught and imprisoned in the pockets and there ground into mud, which may be carried away by the current to the open sea. Wherever we obscrie a shore which by its wearing produces much detritus, we are sure to find a number of these beach-mills whereon the bits of rock are ground to powder. From them little pebbly waste escapes seaward, as is shown by the fact that, though in all geological ages the sea has been at work upon vast stretches of shore-line, it is rare, indeed, that we find in the rocks any of the characteristically ovoidal pebbles which have been shaped by the waves. Even to the cursory eye the beach pebbles have distinct peculiarities which separate them from all other similar fragments. They are always spheroicls, that is, they closely approach the globular form, while those which 
are formed, as most pebbles are-by glacial action-are much more iregular in shape, generally being many-sided with the angles somewhat rounded. Even the pebbles made by the torrents of elevated countries cliffer in character from those produced by wave or ice action.

The student who would make a study of sea-beaches, a task to which the would-be geologist may well give a long summer vacation, cannot do better than to resort to eastern Massachusetts, planning his work so that he may travel on foot from Newburyport to Wrood's Holl. In this journey, which, with the detours required by the fretted character of the coast-line, will extend to about three hundred miles, he will find fairly good types of all the coastal conditions presented by the Atlantic shore-line south of Greenland and north of Floricla. It is true that he will not have very good specimens of fiords, nor of the supert marshes which are offered by the savannas of the Georgia coast, but such features as straight beaches will be well shown about the lpswich River, excellent dune phenomena may be found in Essex and about Provincetown, pocket-beaches abound on Cape Ann and along the shores of Boston Habor, and Cape Cod exhibits at Provincetown and elsewhere beautiful examples of hooked spits. Marine marshes are beautifully shown behind Plum Istand lieach and Revere Beach, while the improved area of the same nature in Marshfield shows the steps by which such areas may be won to agriculture, and something of the profit which may be thus attained. At other points on Cape Cod the conversion of the marshes into cranberry bog exhibits an interesting type of agriculture, one which is peculiar to this country.

As we pass from the northern portion of the Atlantic 
shore of North America to the southward, the pocket-beaches increase in dimensions, and contain more sand. Croing toward the tropics, this familiar element of the sea border becomes constantly more and more abundant, until beyond Cape Cod the hard rocks are rarely visible, and the peblules, if they occur, are altogether from the glacial waste, either that which is excavated from the shore or that brought in by the sea-weed. From New York to Florida, and thence to the Rio Grande, there are no firm materials from which pebbles can be made. We pass from the northern type of pebbly pocket-beaches to the straight sand-coasts of the south by a somewhat gradual transition. The accumulations of detritus become more extensive, here and there the horns of the re-entrant bays no longer project far enough into the sea to contain the large amount of material which finds its way into the depression; so a portion of the matter flows out and streams down the shore to the next bay; this in turn is more completely filled, and finally we come to the conditions of continuous beaches.

The change in character of the shore which is brought about by the passage from the cliff-and pocket- to the continuous beach, is caused by the alteration in the geological conditions of the continent in the district in which the shoreline is laid. The hard rocks of the high north, because of their resistance to the action of the waves, yield but slowly to the sea. The water next the shore is deep, and the bottom either of firm stone, close-set pebbles, or dense clay; all these conditions are opposed to the formation of sandy shores. Although the pebbly beaches grind up a great deal of rocky. matter, they convert the greater part of it to fine material which forms clay. In the region south of New York, and 
generally in the regions neighboring to the tropics, the beds assailed by the sea are of more friable nature than those of high latitudes, and yicld rast quantities of sand, which are distributed far and wicle over a rather shallow sea-floor. The greater part of the vast accumulations of sand along our southern coasts come to the shore from the bottom of the neighboring shallow sea. 'The way in which this sand works in against the coast can easily be understood through a knowledgre of the processes which are brought into action by the movements of the sea-waves over the shallow continental shelf. First, as to this continental shelf or fringe of shallows which shirts the ocean shores.

If the reader will take the admirable general charts of the Atlantic shore and neighboring sea which have been prepared by the United States Coast Survey, he will find, on cxamining the soundings of the district from the St. Lawrence to Florida, that the water very gradually decpens from the sea. margin for a varying distance, amounting in places to as much as one hundred miles, declining generally at the rate of only four to six feet in a mile, for a distance from the shore, and then plunging down steeply to the abysmal depths of the sea. On the coast of Europe there is a similar shelf, and researches in other parts of the ocean seem to indicate that this broad platform is a common feature of the continental margins, being present along all parts of the great lands which have long been elevated above the sea and thus much exposect to the action of the tides and waves. This shelf is doubtless in the nain composed of the waste from the neighboring land which has been taken to sea by the rivers, or contributed by the sea-waves to the ocean bottom. These contributions of sediment have been borne to their places mainly 
by the action of the tidal currents, which are the principal agents serving to distribute sediments next the shores. The action of the ticle is in brief as follows: In the profounder depths of the ocean, say where it is three miles deep, the water in a tidal swing moves to and fro for only a few hundred feet of distance twice each day. This rate of movement is so slow that it cloes not disturb the finest mud. As the tidal wave moves in toward the shallower parts of the oceanfloor, the swing of the sea increases with every stage in the decrease of the depth, until on the higher part of the continental shelf the current which it creates becomes strong enough to move the grains of sand to and fro with each oscillation which the heavenly bodies communicate to the water. In the shoals next the shore the movement is often strong enough to roll even the pebbles about.

In order to conccive the effects of this tidal movement, the student should imagine a billiard-table slightly tilted at one end, and a number of balls pushed with the same amount of force up and down the slope. He will easily understand that the balls will, when thus pushed up and down the table with equal impetus in each direction, gradually work toward its lower end, and this for the reason that the force of gravitation acts ever to diminish their upward movement and to increase their downward journey. The seaward slope of the continental shelf may then in the mind's eye be given the place of the billiard-table, the grains of sand that of the balls, and in lieu of the force applied by the hand we have the alternating push of the ticle. There, age by age, the swinging of the water in the tidal flow and ebb, each morement acting with equal force, gradually, with the daily journeys, works the particles of sand from the shore where they are formed, out 
into the deeper water, where the currents can no longer stir them, and where they may be bound to the bottom by the organic ooze or slime which abounds on the ocean-floor. In this manner, by the endless procession of tide-borne sand, the greater part of the continental shelves are formed.

The work of the ticles in conveying the sediments from the shore out toward the margin of these great submerged sand-plains, is directly and often effectively opposed by the movement of the sea-waves. These surges, like the inconceivably wider ticlal oscillations, have little effect upon the bottom of the ocean in its deeper parts. If the abysmal seafloor were inhabited by a race of philosophical fishes, and they were provided with the most accurate appliances for observation which have been invented by men of science, they would hardly be able to detect the effect of the waves, however high, when they rolled over the surface three miles above the ocean-floor; at most they would find the water lifted a fraction of an inch as the wave advanced, and lowered by the same amount as it passed by. The trifling currents thus induced would not disturb the finest mud upon the bottom; but if the imagined aquatic observers carried their studies to higher levels of the sea-floor, they would find an ever-increasing drasging action produced by the waves upon the base of the ocean. IThen they came to the shallows of the continental shelf, they would perceive that the water under each successive wave swung toward the shore with sufficient energy, where the surges were high, to drag the sand up the declivity. The less the depth of the water, the stronger this movement would be, and next the beach, where the water was not more than fifty fect deep, the action would be strong enough to urge coarse sand or even fine pebbles to the margin where 
the breakers would commit it to the strand. The result is that the waves, which are only powerful when they run towarl the shore, oppose the work of the tides, and tend to return to the margin of the continent the fine detritus which the tides labor to carry away.

While these two irregular classes of marine movements of tides and waves are contending with the grains of sand and mud, the ocean currents in their continuous, though slow, pace share in determining the fate of the wandering bits of stony matter. Almost all parts of the shallow water near the shore are the seat of these oceanic rivers, which flow with tolerable steadiness in one direction. In their currents, which generally flow at right angles with. the run of the tides and waves, the particles of sand and mud are given a decided set in one direction. Thus on the eastern coast of North America there is a prevailing, though variable, southerly current which skirts near the shore over the surface of the continental shelf, and to a certain extent operates to convey all the sandy matter from the northern part of the continent to the southern part of its shallow waters next the coast. It is now contributing to the growth of the vast submerged sand-plains which extend from Cape Cod to Cape Florida, and in past geological ages has doubtless helped to bring to their place the extensive deposits of sand and clay once a part of the continental shelf but now uplifted into the dry land of the Southern States. We may recognize the fact that these lowlands were originally portions of the continental shelf, by their vently undulating surface, which is exactly like that of the neighboring sea-floors, by the nature of the fossils in their beds, as well as by other indications of a more recondite nature. In fact, the greater part of the surface of the continents was 
loubtless originally formed as shore-shelves near the old lands, then clevated above the sea, folded into mountains, and worn into hills, until we can no longer, or with difficulty, reconize their original aspect.

If the relative level of the sea and land remained steadfast for a consiclerable geologic time, the detritus of a continental sheif would, under the unceasing action of the tides, and despite the perturbing effect of the waves in occasional storms, grow steadfastly to the seaward; but all our study of the relations of sea and land tends to convince us that they are peculiarly monstable. It seems likely that nowhere in the world is the sea-margin at exactly the same height in any two successive centuries. In general this variation is so slowly brought aloout that in the brief moment of time for which we have any account, in the case of the longest-known shores, we lo not have cridence of it, and the sea-level is said to be permanent. Again, it is sufficiently rapid to be observable in the duration of a single human life. Thus on the coast of New Jersey there is a tolerably rapid subsidence of the land, which is sinking at the rate of near two feet in a century. Along the shores from Eastport, southward, there have been many ups and downs of the shore since the glacial period; within a range of from a few score to a few hundred feet, the last variations appear generally to have lowered the shore in the regrions south of New Brunswick. In those regions where the later movements of the coast-line have been of an uprising nature, the effect is to bring a great deal of sand, which had been in too deep water for the waves to affect the particles, within the power of the surges. In these cases the coast-line becomes inundated with sand swept in from the sea.

It is characteristic of the typical sandy shores, that their 
materials are apt to be in a state of continued instability; their sands are generally moving with considerable speed in the direction in which they are borne by the shore currents. The march of the sands along the shore continues until they

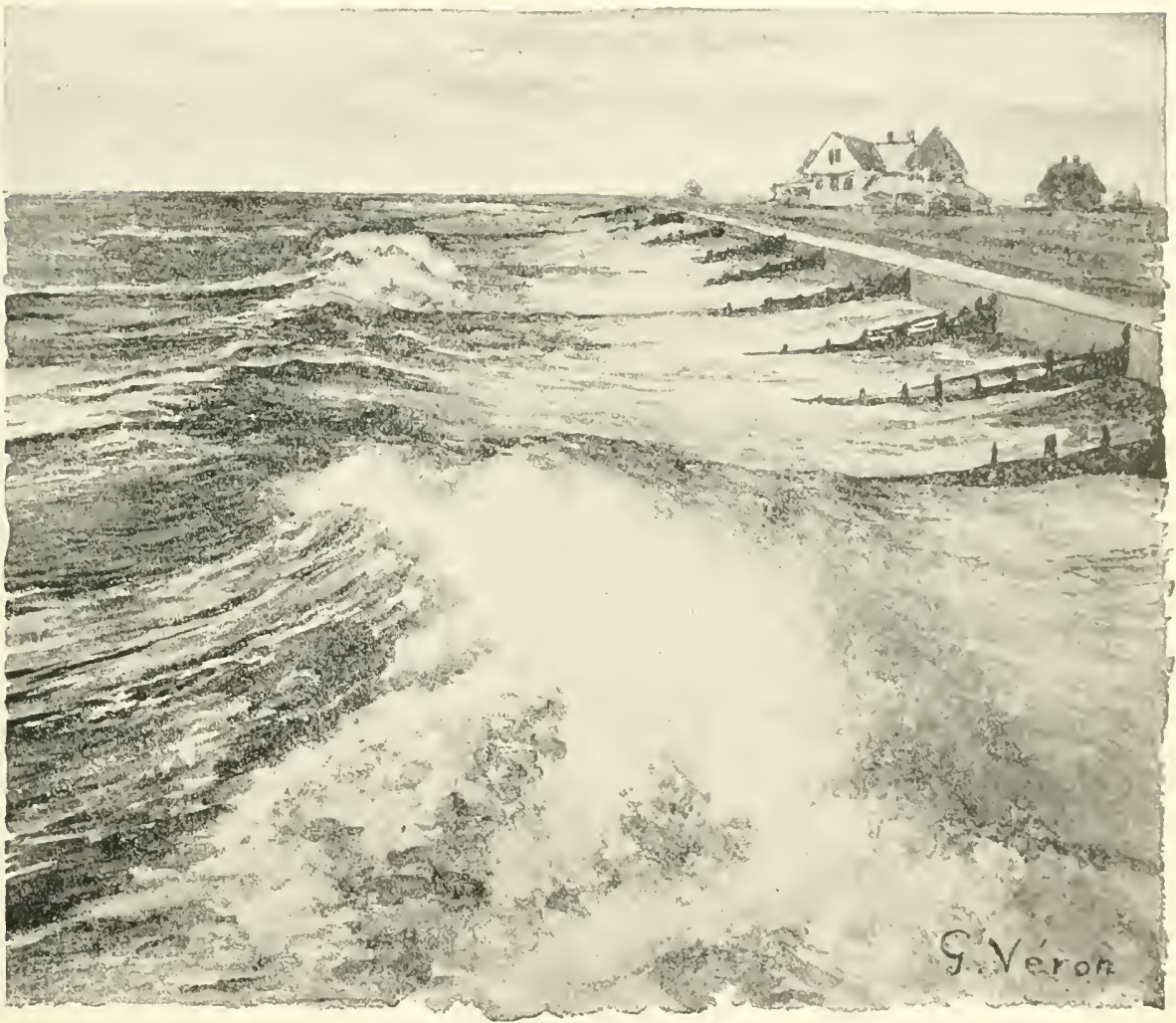

Moderate Surges seen along their Crests

The shore is in its nature alluvial, and the most approved method of protection by means of sea.wall, together with spur breakwaters, is shown. The object of these breakwaters is to keep the sand and pebbles from working along the beach under the influence of the waves and currents.

have attained the extremity of the coast, or found their farther progress obstructed by some strong ocean current which sweeps the incoherent matter away into the depths. Thus along the Atlantic shore from Cape Hatteras to Cape Florida 
the sands are constantly and rather rapidly moving to the southward. At the last-named cape the coral reefs carry the shore out to the edge of the northward-flowing Gulf Stream, which speedily conveys a great part of the mobile waste into the deep valley between the Bahama Islands and the margin of the continent. Where these coast-moving sands abound the beaches usually lie upon the seaward face of long, low, sandy islands separated from the shore by lagoons. 'These sand-bar islands are a very conspicuous feature along all the shore from Portsmouth, N. H., to Cape Florida, and again along the Gulf of Mexico from the western coast of Florida to the mouth of the Rio Grande. This peculiar type of beaches appears to be originated under the following diverse conditions: Whenever by an elevation of the shore-line a new beach-line is to be formed farther out to sea than that which previously existed, the construction is begun, not at the very water's edge, but at a distance out from the shore at the depth where the storm-waves break, in perhaps twenty feet of water. When the wave topples over in the surf, all the sand which it has swept forward from the seaward falls down, and each successive wave adds to the supply, until the mass reaches to the top of the water and forms a new bar. Upon this elevation the storms build yet more sand, grasses take root, and low dunes are formed. As the waves bring in not only sand but much shelly matter and the bones of fishes, the deposit may make tolerably fertile land, such as is found on the long beach islands which border the great lagoon known as Indian River in eastern Florick. In other cases, where the sea-shore slowly sinks, similar islands may be formed in a rather different way. If the continental land is low, as it is next the sea in all the Southern States in this country, the 
beach-wall may in time be built to a considerably greater height than the land upon which it formed. If the land sinks down, the waves and winds may constantly add to the height of this growing beach, so that its crown is kept well above the surface of the water, while the interior land, having no such means of adding to its mass, slowly subsides below the level of the sea.

These outlying beaches, especially where they are swept by strong, coastwise-running currents, are apt to work rapidly in toward the land. Thus on the southern shore of the island of Martha's Vineyard, where an extensive series of lagoons is shut out from the open water by a low sand barrier, the coast current constantly cuts away the sand next the shore and conveys it to the eastward until it is discharged around the end of the island to form the great promontory of Cape Pogue. This leads to the deepening of the water next the shore so that the waves have very free access to it. In times of great storms the swash from the surf sweeps clear over the beach, and in its movement conveys a great quantity of sand from its outer to its inner wall. In this manner a beach moves inward in much the same way as a sand-dune, rolling orer and over itself in its forward motion. On the southern coast of Martha's Vineyard the inward march of the beach is now at the rate of about three feet per annum. It is now probably near a thousand feet from the place it occupied when the land was first seen by the whites.

These barrier-beaches, arising, as we have seen they may, from either the uprising or the downsinking of the continent, are extremely common features of the ocean coasts; probably near one-fourth of the continental shores are fringed by them. They are of much interest to man, not only because they 
afford numerous harbors, but for the reason that they lead to the production of certain groups of marine marshes, which may be readily converted into very rich arable land. Some of the most fertile of the dyked lands of Holland were originally of this nature; and on the eastern shore of the United States there is awaing the thrift which shall win it to agriculture an area far greater than that occupied by all the Netherlands. These marshes, the products of the sea-beaches, afford such promise of good harvests in the generations to come, that we may devote a portion of this chapter on the history of the shore to a brief account of their curious phenomena.

As soon as a space of tidal waters is protected by a barrier-beach from the incursions of the sea-waves, its bottom is occupied by various species of marine plants, of which the well-known eel-rass is the most common. These forms make a network in which the currents of the tides, or those of the rivers which may discharge into the embayed area from the land, are deadened and lay down such sediments as they may be bearing. A host of animals dwell in this vegetation, and contribute to the deposits which rapidly shallow the water. When by these accumulations the surface is brought to the level of low tide, several kinds of. true grasses and other flowering plants, as well as certain sea-weeds, continue the construction of the sedimentary deposit until the surface is brought to a level a little below high-ticle mark. This growth of the higher tidal marshes usually begins next the shore, while that of the cel-grass flats, which never rise above the retreating tide, may take place anywhere in the basin where the currents are not strong enough to sweep the plants away. Starting at the shore the grassed marshes extend gradually outward until they leave only narrow channels for the en- 
trance and exit of the tidal currents, as for the escape of the land waters. In this manner bays originally of many square miles in extent appear as grassed plains, except for a few hours at high tide, when they have a foot or two of water on their surfaces. Thus the great marine marshes which have grown in the quiet waters land-locked by Plum Island, near Newburyport, Mass., have an area of about sixteen thousand acres, and there are many others in New England which exceed a thousand acres in area. Between New York and Portland, Me., a careful study has shown that there are over three hundred thousand acres of these lands, all of which are reclaimable and will make exceedingly fertile fields.

In the region south of New York, in New Jersey, Delaware, Maryland, Virginia, and the Carolinas, there are other and far more extensive marshes of the same general nature. It seems probable that ultimately not far from two million acres, or over three thousand square miles, of excellent land will be won from these fringes of the sea to agriculture, and this with a relatively slight expense for the necessary engineering work. With more costly contrivances the area to be won to the best uses of men may be brought to more than three times this amount. There are, in other words, the agricultural possibilities of a Holland in these inunclated lands awaiting the time when the increased population of this country shall make it necessary to utilize these naturally productive areas.

The process of subjugating these fields where the ticlal rise and fall exceeds four or five feet is simple. The beach which protects the embayment from the sea usually constitutes a most effective dyke against the ocean waters. There 
is grenerally a single breach in this wall through which the tide gains ingress, and through which the land waters pass into the sea. If the outflowing streams of fresh water are small, as is generally the case, it is only necessary to place a dam at this exit, provided with gates which open at low tide to allow the fresh water to escape, and close as soon as the tide begins to flow in. In this way the surface of the soil once overflowed at each tide is kept permanently from three to six feet above the level of the water in the river channel. It requires some time and care to take out the saline matter from the marsh, but within a few years the soil will prockuce luxuriant and varied crops. Its fertility is greater than that of the prairies, and from its depth and the variety of its natural constituents it seems almost inexhaustible. An excellent example of the possibilities of this interesting means of winning land from the sea is afforded by the Green Harbor lands of Marshfield, Mass., where a district of about fifteen hundred acres was freed from the sea by a dam costing a few thousand dollars.

Where the tidal fall and rise is less than five feet, it is difficult to secure the necessary dryness for tillage by any automatic system of drainage. In these districts recourse will probably have to be had to pumping by means of windmills, a method of drainage which has been found effective and economical in the low countries about the mouth of the Rhine.

Before we close this imperfect story of the sea-beaches we may well note the common fact that the sand of which the bulk of their masses is composed is vastly more durable than the seemingly more resisting pebbles. As we have seen, pebbles wear out rapidly. Scarcely any, even the hardest, 
can stand a year of steady thrashing on the shore, but these sands endure for ages. 'The reasons for this are simple. In the first place, each grain of sand is an admirable illustration of the principle of the survival of the fittest. If it be not perfectly coherent and very hard, it will not be carried far before its weakness is found out and it is broken into mud on the pebble-beaches, where it is generally made and borne away by the sea to the deeper water. Then, because of their smallness, the grains lie with so little interspaces between them that they hold the water next their faces by capillary attraction. When a wave strikes the shore the grains of sand are pounded together, but they do not touch each other. If we press on the wet sand with the foot we see that the mass whitens as the pressure is applied and a part of the interstitial water is poured out: take the foot away, and the water returns to the crevices between the grains. Only dry sand will rub, grain against grain, and give the audible sound which when it is sharp and clear is called singing. No beach will thus creak or sing beneath the feet when it is wet.

This curious endurance of rocky matter, in its comminuted form, to the erosive force of the sea, makes the sand the natural protector of the land against the fierce assaults of the sea. If sand were easily pulverized, if it were readily floated away, if it had, indeed, any other than its actual assemblage of properties, it is doubtful if the lands could have made good their place in the contest with the ocean. These doughty little champions have certainly kept for our use empires which but for their good work would long ago have vanished beneath the waves. Thus a process which begins with swift wasting of the land on the exposed cliffs of 
the sea, and is continued in the wearing of the pebble beaches, ends in the protective work of the sand beaches. So it is with nearly all the processes of nature; however destructive the work may seem to be in its inception, the end, if we can but see it, is ever creative. 


\section{THE DEPTHS OF THE SEA}

Modern Interest in the Deep Sea: Conditions of Inquiry._. Shape of Ocean-floors: Absence of Mountains and Valleys._Coral Reefs. - Continental Shelf. - Permanence of Continents-Plants and Animals of the Sea.-Conditions of Marine I.ife : Absence of Seasonal Changes. - Marine Communities. - Abysmal Life.-Detrital Accumulations. -Fate of Sunken Ships.

Ever since man began to speculate concerning the unseen parts of nature, the spaces of the sea have shared with the vaster realms of the encircling heavens the manifold excursions of the imagination. The poet and the philosopher, whose paths upon the land most often lie far apart, have alike sought to tread over the hidden ocean-floors. For a time the realms of the sky, because they are more visible than the submerged realm, were the favorite field for speculation. The Greeks, by far the most richly endowed in constructive imagination of any of the ancient peoples, gave little thought to the regions beneath the sea. The true love of the deep, and interest in its hidden regions, is a matter of modern days. The people of northern Europe have felt these motives more strongly than those of any other lands. The Scandinavians were the first navigators of our race who learred the pleasure which comes to those who break into an unknown sea; a thousand years ago they dared in frail barks the fierce tempests of the North Atlantic; led thereto by no clearly defined purpose of conquest or propagandism, but 
inspirect, it would seem, by the pleasure of dangerous cruising. It is principally among the people who share this Scandinavian blood that we find that vivid interest in all that pertains to the ocean which has led to some of the most fruitful and interesting inquiries of modern science; researches which have created the branch of learning which is termed thalasography, or the description of the ocean.

The study of the ocean depths is an extremely difficult inguiry: we know far more concerning the form of the moon's surface, though that sphere is a quarter of a million miles away, than we can ever hope to learn of the shape of the ocean-floors. There are few instruments as yet devised which can give us any considerable information as to the conditions at any great depth below the surface. A century agro the only apparatus of submarine research was the plummet, by which the navigator, to learn the position of shallows, sounded for the clepth of at most a few hundred fect. A little tallow on the bottom of the lead brought up some framments of the sea-floor, and showed whether it was sandy, muddy, or covered with fragments of shells. A hundred years ago nothing was known as to the greater depths of the ocean. The lines to which the sounding leads were attached were limited in length to about six hundred feet; when the bottom was not found with them, the vessel was said to be "off soundings." 'The depth beneath her keel was then left to conjecture. With the modern increase in curiosity concerning the ocean, the lines were lengthened and the weights increased, so that some information began to be obtained as to the deeper parts of the sea. But there were many and serious difficulties encountered in these explorations. The ropes had to be of considerable size to sustain 
the heavy plummets, and the friction of these cords on the water, though not noteworthy in shallows, became very great

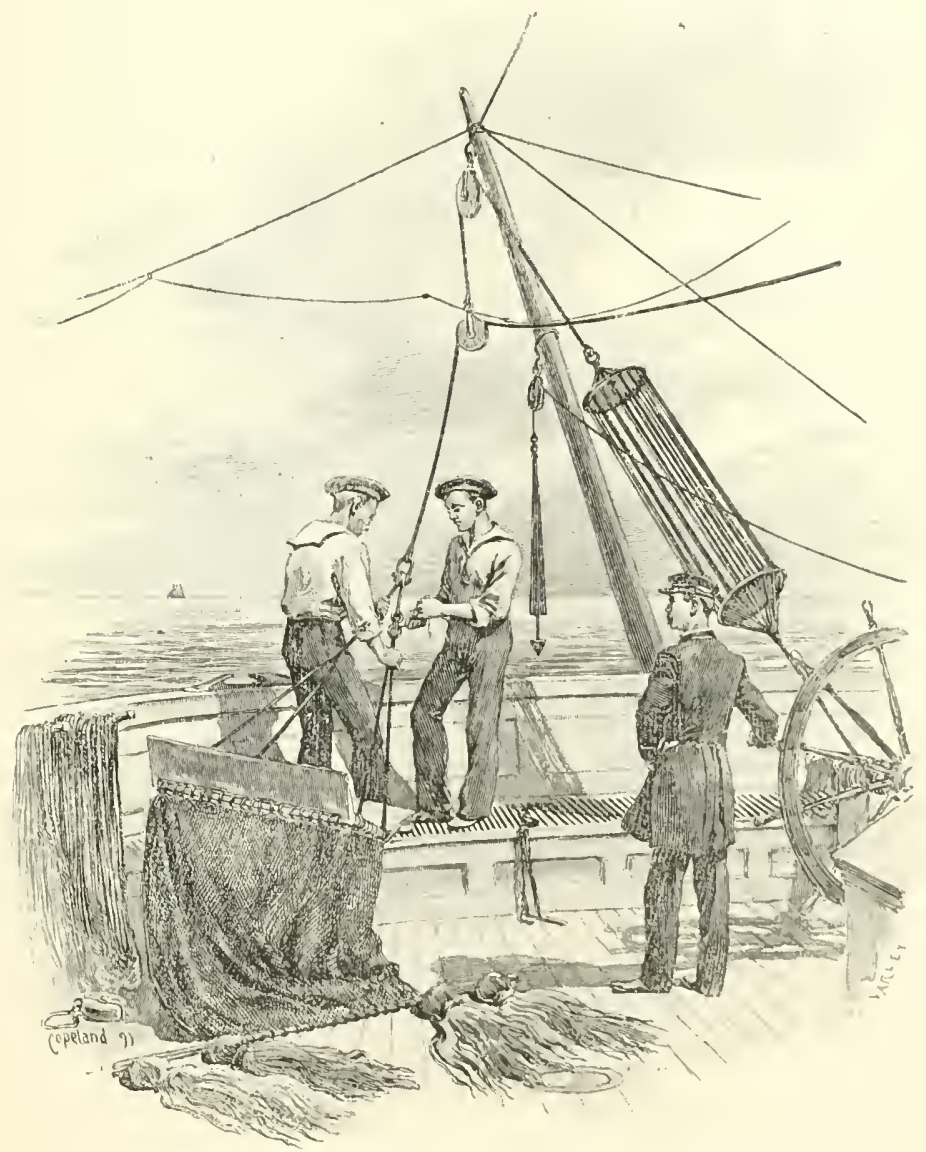

Sketch showing the Arrangement for Dredging in the Deep Sea

The dredge is seen in the foreground. The fringed tassels are intended to entangle objects which rest upon the bottom. The drum-like piece of apparatus is a set of springs intended to prevent the breaking of the line by sudden strains.

when a mile or more of depth was encountered. In the abysmal portions it required hours for the weight to drag the hempen rope to the bottom, and a yet longer time to lift it 
agrin to the ship's deck. In rery deep water so slow was the clescent of the weight, that it was not easy to tell when it had attained the ocean-floor. Moreover, as the ocean waters are often pervaded by currents of considerable velocity which move in various directions, the thick cord in its downgoing would often flex, now this way and now that, and thus give very exaggerated records of the depth at any point.

The most important of these difficulties encountered in exploring the depth of the sea, have, through the skill of the American and English explorers of thalassal problems, been overcome. The lead is no longer hung on a rope, but is attached to a fine steel wire, which, because of its tenuity and smoothness, slips easily through the water; the weight is so arranged that when it strikes the bottom it is at once detached from the line, which is then easily wound back to the drum from which it was lowered, while the plummet itself is left to be entombed in the strata forming on the seafloor. Although these very clever inventions, as well as the complicated and beautiful machinery by which the miles of delicate wire my be lowered and hoisted in the rolling sea, have made it possible for a properly equipped exploring ship to determine, in a tolerably accurate manner, the depth of water at any point, the information which is gained even by very numerous soundings, though valuable, is very meagre. Let us fancy that the atmosphere was as impenetrable to vision as the deptlis of the ocean, and that creatures which dwelt above it should seek to learn the shape of the land by means of a few thousand soundings disposed in lines here and there, so as to give what we may term sections, over the surface of the terra firma. We can easily imagine that 
the information would be very incomplete. Such a sorge as the Grand Cañon of Colorado would have but a bare chance to be noted; a volcanic peak like Atna, though it rises two miles above its base, would most likely escape observation.

If our imagined super-terrestrial beings should limit their inquiries to the facts developed by the plummet, they rould have but the most general notions as to the form of the surface they were exploring. We can conceive them using the

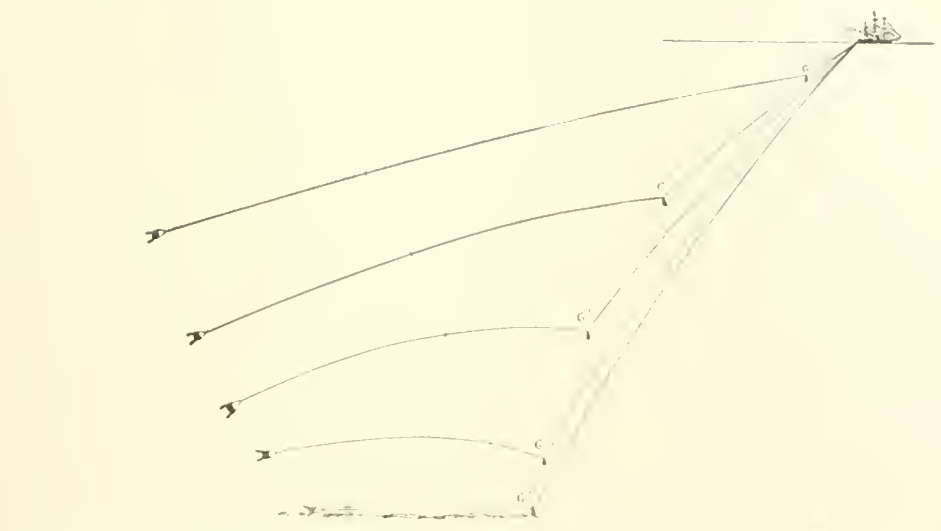

Diagram showing the Position of a Deep-sea D edge as the Line is Paid Out fromithe Stern of t. Snp

The letters G, G', etc., show the position and effect of the weight which is used to bring the dredge into the proper attitude.

other aids in their research which have been devised by the explorers of the deep sea : the dredge, a contrivance like a scoop, which is dragged over the bottom, so as to collect a sample of the deposits which are forming there. I few thousand essays with this instrument would certainly give some notion as to the nature and variety of the organic forms which people the surface of this sphere, and are contributing their bodies to its dust on sea-floor and land. Y'et we readily fancy. that these observations would afford but an inadequate basis 
on which to construct a picture of the hidden realm. So, too, the thermometers which grive us the ranges of temperature in the depths, and the instruments which collect water from the various levels of the sea, in order that it may be subjected to chemical analysis, though they provicie us with valuable information, do not give us anything like the accurate data for determining the climatology of the ocean-floors that we have secured from the land. Similar observations on the land made by beings in the upper air, even if they were applied only to the natural wildernesses of the earth, would afford only details which would require exceeding skill to frame into important and trustworthy general views. This skill has fortunately been commanded by the naturalists who have prosecuted the modern studics concerning the occans: no department of modern science has so well united the daring of the man of action with the patient labor of the closet student; hardly any other has so profited by the advance in the mechanic arts. The methods of the students of the deep sea may indeed serve as a model of the scicntific research which is so characteristic of our century, for they combine in an admirable way patience in difficult inquiry with skill in interpretation. The affirmed results, at least those which are likely to prove interesting to the gencral student, are among the most fascinating chapters in the history of the earth.

The student who from the familiar studies of the land surface-studies which we are all insensibly making in the daily experiences of our ordinary lives-comes to the margin of the sea, is naturally led to the opinion that the ocean-floors have a form essentially like that of the continental fields. At the shore he finds the mountains and plains of the land passing by a gradual decline of the surface below the level of 
the water. The emerged mountain-tops often form a fringe of islands extending some clistance from the coast-line, and the valleys are prolonged as deep bays which penetrate far into the land. Thus the land and the sea appear to be blended in a way that very naturally leads to the supposition that the ocean-floor is merely an inundated portion of its surface, differing from the dry parts only in the absence of certain minor features, such as river-valleys which are due to actions peculiar to the land.

Naturalists for a long time adopted this popular vicw concerning the conclitions of the sea-bottom. Observing that the greater part, if not the whole, of the land was made up of sediments which had been accumulated on the sea-floor, the stu. dents of this field were led to the idea that sea and land had often changed places; no part of the earth for any long period escaping from the invasions of the ocean. Gradually, with the advances in knowledge concerning the history of the earth, these students have been driven to other views. While they are thus forced to allow that the continents have been subjected to great alterations of form, a part of their surface from time to time sinking beneath the sea while other portions which had long been under water rose above its surface, they find good evidence that, as a whole, the seas and lands have not changed places, but that the greater oceans have been permanent features in the physiography of this planet. There is doubtless a debatable area next the shores of each continent, which is now won to the realm of the land and now to the domain of the waters, but there remains a vast field, probably including more than half the oceanic area, which for a great time, perhaps since organic life has tenanted this sphere, has been always in the condition of deep sea. 
Accepting this view as to the tolerable permanence of land and sea with the greater assurance, because it has slowly won its way to belief over the previous opinions and prejudices of students, we are prepared to find that the conditions of the ocean-bottom are in many regards entirely unlike those of the land. It is casy to see that the shape of the land is mainly determined by a contest between the down-wearing action of the water which falls upon its surface as rain or snow, or is swung against it in tides and waves, and the uprising movement which lifts the mass of the continent and wrinkles the underlying rocks into mountain folds. Rivers and glaciers have battled with these ascending masses of strata, they have carved out the valleys and gorges which fret the land in every direction; even the plains which appear to feel little of this erosive action generally owe their horizontal aspect to the fact that the wearing agents have done their most effective work in these areas. We readily perceive that all this mighty machinery of flowing rivers and beating waves has no place in the depths of the sea. It is true that the ocean has great streams upon its surface, some of which, for certain parts of their courses, move with the speed of the larger rivers; but these swift currents are superficial things; they rarely if ever touch the bottom except where they come upon the shores of continents or islands, but fow upon a base of deep-lying nearly motionless water. While everywhere upon the land, even in the most arid regions, there are occasional rains, and for a time the torrents do their appointed work of wearing away the surface of the earth, the deeper ocean-floors are practically always the seat of deposition, that is, they are receiving contributions of sediment from the rivers of the land, from the waves and tides of the shores, from the vast 
amounts of clust thrown out of rolcanoes as well as that which falls from the celestial spaces. In a word, the land is characteristically the place where the stratia are in the course of destruction, and the sea-floor the laboratory where these materials are separated from the water, partly by gravity and partly by the growth of organic forms, and built again into compact rocks.

The result of these differences in conditions is, that while the land is carved into innumerable valleys which mark the process of its destruction, the sea-floor is approximately level, for that is the shape which the growing deposits assume as they are accumulated. But there are yet other influences which serve to give to the sea-floor a uniform aspect. Chief among these we must reckon the prevailing absence of true mountains in the fields which are covered by the ocean waters. Althougl these vast realms contain numerous elevations, some of which are of magnificent proportions, it seems tolerably certain that true mountains-that is, elongated heights produced by the folding of rocks into ridges and furrows-do not occur in the abysmal portions of the ocean.

The evidence of this lack of mountains in the deep seas, though inferential, is very satisfactory in its nature. 11 e note that the average depth of the oceans, as determined by many thousand soundings as well as by the speed with which the waves caused by earthquakes travel over their basins, is about fifteen thousand feet, while the portion of the marine fields where the depth exceeds twenty thousand feet is extremely limited, and the most profound abyss yet encountered in sounding is only about twenty-eight thousand feet below the surface. In the land we find many hundred peaks 
which exceed fifteen thousand feet in height, and some score which rise twenty thousand feet above the sea level. There are indeed several considerable areas of mountainous country where extensive fields attain a greater height than the average depth of the sea. It is thus at once plain that if mountains developed in the ocean-floor as freely as they do on the land there would be a great number of them rising above the plane of the seas, but in fact that there is not a single distinct mountain peak rising above the water level at any great distance away from the margins of the continents. All the numerous islands of the wide oceans are either coral reefs or the summits of volcanic cones.

It is furthermore evident that if mountains grew upward from the sea-floor they would attain the surface of the water without being subjected to the erosion which has robbed the elevations of the land of a great part of their height. If we carefully examine any of the great mountainous peaks of the continents we find that they have been much worn away by the rivers, torrents, frost, or glaciers, which have always operated upon them; but mountains growing upon the sea-floor would be safe from these assaults until they rose above the surface of the water. IVe would on this account expect to find them even more abundant and of loftier forms in the marine areas than on the parts of the earth's surface which rise above the sea. We are therefore forced to the conclusion that mountains do not form upon the sea-floor, or if they develop there they attain no such dimensions as they exhibit upon the land.

Although the deeper sea-floors probably lack mountains, they are not without striking reliefs which if they could be seen would present all the dignity which their height gives to 


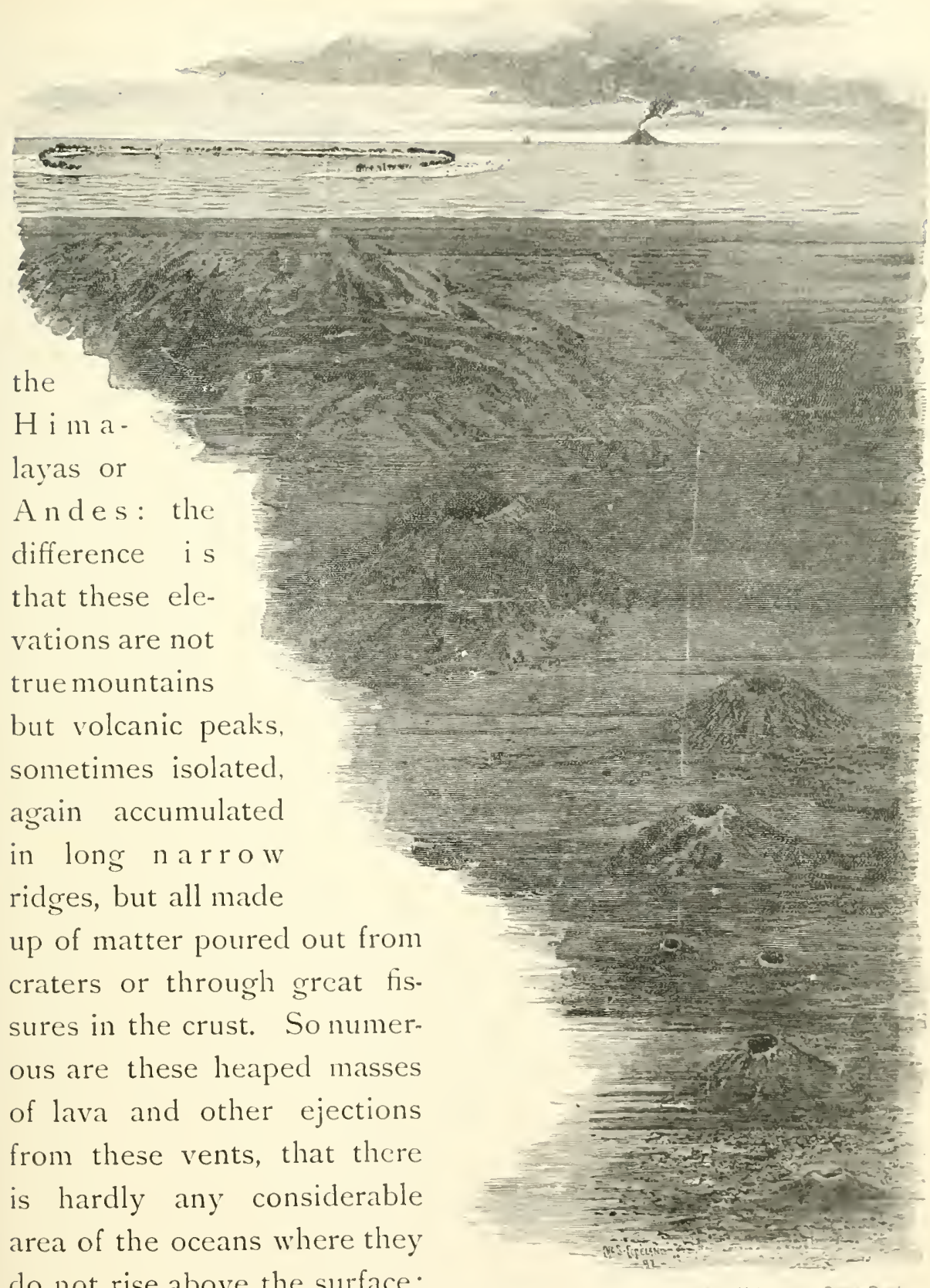
do not rise above the surface; there are indeed thousands of these volcanic peaks distributed from pole to pole.

Suggestions concerning Submar ne Volcanoes C C Fie : and Volcanic Islands

In the foreground the upward grow th and lateral enlarcement of volcanic cones is indicated. The larsest of these has been levelled off and occupied by an atoll. In the distance a volcano, still active, is in a state of slight crupt. on. 
Let it is likely that only a small part of these elevations attain the surface of the ocean. P'robably the greatei part of them remain buried beneath the sea, and are only imperfectly perceived when the sounding lead indicates an elevation of the bottom. Thus on the floor of the North Atlantic there is apparently a long discontinuous chain of these elevations extending from the lcelandic group of islands southward to the Azores. If an explorer could view this part of the seabottom he would probably find that the line of craters was as continuous as that exhilnited by the volcanoes of the Andes. In the invisibie landscape of the sea-floor, volcanoes play the part of mountains on the land. It seems indeed clear that these elevations, due to the action of the earth's interior fires, are in their way as characteristic of the deeper seas as the mountains are of the land portion of the continents: the volcanic field is so essentially marine, that of the hundreds of vents that have been in activity within the historic period not one is situated more than three hundred miles from the margin of the sea.

Besicles the rolcanic peaks the sea-bottom in certain parts of the tropics and in the regions near to the equatorial realm which are swept over by warm ocean currents is beset with the singular elevations formed by coral reefs. Next the shore these reefs take on the form of long submerged walls, sometimes many hundred miles in length and only a hundred feet or so in height. To the eye they would appear as singularly regular and artificial terraces, their crests on an exact level for a considerable part of their length. - Here and there the wall would present port-like openings through which the streams of the tides and rivers find entrance and egress. The reefs of the deeper sea present a very different aspect; they 
are usually in the form of very lofty cones rising steeply from the depths of the ocean to the height of a few fect above the level of the water. On their tops there is generally a shallow cup-shaped depression of a few score feet in depth, bounded by the low flat wall of the living reef of coral sand which had been formed along the shore. 'The origin of these deep atoll sea-reefs is not yet perfectly understood. Mr. Darwin's explanation, long considered satisfactory but now brought into doubt, was to the effect that they were produced wherever a massive coral growth was formed around the flanks of a slowly down-sinking island, the polyps building their limestone wall upward as the peak lowered into the depths of the sea. Dr. John Murray, the well-known oceanographer, has recently shown that these basin-shaped reefs may be formed wherever shallows are produced in situations where they are swept over by a warm marine current. The upward growth of the coral tends to form a cap upon the shoal which slowly rises to near the level of low tide. Attaining this altitude, the central part of the mass begins to dissolve away, and the process of solution continues until a basin is formed, while on the outside margin of the reef the polyp communities continue to grow, and from the dibris which they afford under the beating action of the wares the ring-like island is formed. Although there may be cases in which the elaborate hypothesis of Mr. Darwin is applicable. there can be no doubt that by far the greater part of the atolls have developed in the manner indicated by Dr. Murray.

let another singular feature in the topography of the oceans is found in the great shelf-like shallows which usually border the margins of the continents. These remarkable 
features are best known along the coasts of the North Atlantic, perhaps for the reason that there alone is the form of the bottom ascertained. In groing from New York to Liverpool, the traveller for the first hundred miles of his eastward course passes over a portion of the sea where the water rarely exceeds five hundred feet in depth; the bottom slopes gradwally towarl the central portion of the ocean, at the rate of about five feet to the mile. There are occasional broad swales on the nearly level floor, but as a whole it is much more nearly a plain than any similarly extensive part of the prairic land of the Mississippi Valley. This gradual descent toward the deep sea is terminated by an abrupt slope where the bottom declines at the rate of from ten to one hundred feet to the mile, from the crest of the submerged plain to the abysmal depths of the ocean.

Unlike most of the submarine topography it is possible for us to get a clear idea as to the general character of this continental shelf from certain portions of the dry land which have recently been elevated above the watery envelope. While it is true that nearly if not quite all parts of the continents have been formed on the ocean-floor, the greater portion of the land surface has been so much warped by mountain building, and made uneven by stream action, that the original impress of the marine conditions has been entirely lost. In the southern portion of North America, from Virginia through the lowlands of the Carolinas, Georgia, Alabama, Mississippi and a part of Texas and Louisiana, we have a portion of this shelf, which was formed when the shore was farther inland and when the area in question was below the level of the sea, constituting a portion of the continental deposits such as is now submerged along our shores. Like 
that part of the submarine plain which is still under water, this lowland of the southern Atlantic coast-lands is extremely level with a slight dip toward the ocean depths, and a faintly undulating surface, the irregularities not usually causing a difference of altitude in one square mile of more than five or six feet. Examining into the materials which compose this emerged portion of the continental shelf, we find that they consist in large part of detritus which the waves and rivers have worn away from this land, and conveyed a little way from the ancient shore, together with quantities of fossils which in their lifetime drew their solid parts from the seawater. Although nowhere else do we find any other so perfect and extensive a fragment of the continental shelf lying above the level of the sea, there is here and there about the great lands evidence that this is the common nature of these cleposits. We may therefore conclude that they are mainly made up of sediments brought to the sea from the neighboring hills and plains of the land.

Until within recent times geologists have generally held to the opinion that the lands and seas had occasionally changed positions, so that the continental areas were from time to time lowered into the deep, and the floors of the abysmal seas, by a similar alternating movement, lifted into the realm of the air. The researches of Dr. Nurray and others appear to indicate that this alternation of relations does not occur. Nowhere on the land have we yet found clear evidence going to show the existence of any deposits such as are formed in the abysmal regions of the ocean. The students of the subject are now coming to believe that, while the continents have been subjected to frequent oscillations, portions of the surface of each becoming depressed to a moderate depth 
beneath the ocean white other parts are extended farther into the field of waters. these great lands are never deeply submerged, and that correspondingly the abysmal realms are never converted into dry land. This view finds much support in the fact that each of the continental

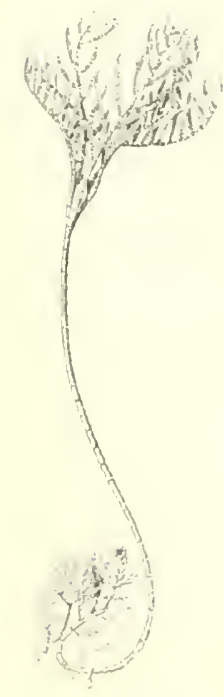

Living Crinoid.

Showing at the top the arms which branch from the calyx which encioues the body carity, and at the batse the rootlike processe's which attach it to the bot tom areas has a somewhat peculiar assemblage of life which is evidently continued in unbroken succession throughout the greater part of the time which is recorded in the pages of the great stonc book whose leaves are the strata of the successive formations. As the past is the index to the future, we may anticipate in the hereafter of this ancient though still youthful sphere, that seographers will often have to reframe the charts of land and sea, but it is doubtful if they will ever delineate as continents those portions of the world which are now in the deeper parts of the occan.

Ve have now considered the principal topographic features of the sca-floors, and have noted the fact that they consist mainly of extensive plains with gentle slopes toward the deep water extending for some distance from the shore, and terminating in steeper slopes which lead down into teeper water; broad undulating frelds in the bottoms of abysmal depths; volcanic peaks generally grouped in long ranges; and lastly the shore walls and steep cap-toppect cones of the coral reefs or isles. We will thereforc turn our attention to the organic forms which people this vast realm-forms so numerous and varied, that we can only consicler their more important aspects, limiting ourselves 
in the discursive inquiry to those features which seem to throw light on the general history of life. 'The first matter to be noted is that now, as in all the past agres of the earth, the creatures which tenant the sea are in organization much inferior to those dwelling on the land. This is true, not only of the organic forms as a whole, but essentially so of every separate group of animals and plants. Thus in the veretable kingdom, the truly marine species contain no flowering forms; none which have devised the functionally and structurally separated parts of root, stem, and leaves, or which combine their offices to afford the well-ordered life of the familiar vegetation of the land. Although the seafloor is generally covered by a coating of detritus far richer in the elements of plant growth than the surface of the land, it does

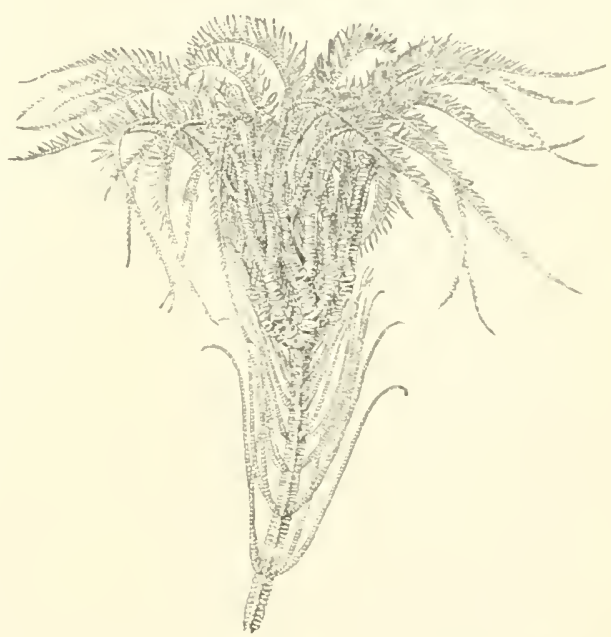

Calyx, Arms, and a Part of the Stem of a Metacrin s- ne cf the Sea $L$ ies

A representative of a group which abounded in the early creological periods, but which is rare in the seas it the piesent time.

not serve the lowly marine plants as a soil; they send no roots into it; they take no nourishment from it, but derive all their sustenance from the water which envelops their stems and fronds. Although there are many diverse forms of marine vegetables, the species are grenerally small and weak structures; only one group, the Macrocystis, is known to attain any great bulk. This tenant of the l'acific and Antarctic Oceans has a stem extending from the bottom of 
the sea to the crown which floats at the surface of the water, and the plant may have the length of one thousand feet or more. Remarkable as is this structure, it is lowly organized, and does not deserve to be compared with our more highly developed land plants, which, in every feature by which we measure superiority, are far above their kindred of the sea.

Although the deeper parts of the seas lack vegetation, the shore belt within the depth of a few score fect abounds in such forms, except, indeed, where the bottom is too sandy to afford them foothold. In this littoral zone, besides the host of forms of lowly organization, the ancestors of which have never been, so far as we know, occupants of the land, there are many species which have adapted themselves by curious transformations of structure and habit, so that they have been able to work down from the dry realm into the sea. Along the high tide line we find sundry species which have overcome the destructive effect which salt water has on the roots of most land plants. Farther down on the marshes other species have extended their experience so that they can live, provided their upper parts are bared at high tide. Yet deeper there are other forms, such as the celgrass, which can perform all their functions and flourish greatly, though they are altogether within the water. One or two groups of trees, of which the species of mangrove are the most important, have become specially modified, so that they may make head against the sea in embayed waters even where they are miles in width, gradually extending the margins of the forests over the shallows to the border of the deep waters. In Florida some hundred thousand acres have thus been won from the sea, and in the more tropical areas the gain of the land which is thus brought about is of yet greater importance. 
Although the animal forms of the deep are proportionally far more diversified, and attain to relatively higher states of life than the plants of that realm, they are also much inferior to their relatives of the land. Each of the great types has its representatives among the marine forms, and certain of them, as for instance the group of animals commonly known an racliates, to which the polyps and star-fishes belong. are, with some trifling exceptions of species which live in fresh watrer, confined to the sea. But all the mammals, birds, and insects, the groups which contain the intelligent animals, are essentially the creations of the continents; the few members of the series which have developed close and permanent relations with the ocean, such as the whales, penguins, and rare marine insects, have clearly been derived from characteristic land forms, which, in the rule strugrgle for existence, have heen forced to resort for subsistence to the sea. The greater part of the higher species avoid the sea, for it is to them a place of death.

Nothing is clearer than the fact that all our land animals have been derived from parent stocks which had their origin in the waters; it is not so certain as to plants, but it is probable that they, too, were first nurtured in the sea. In the land areas these great groups of animal and regetable organism attain their perfection. The articulates and vertebrates are at their best above the level of the waters, and in them alone do we find intellectual species. How does it come about that though the deep has been the cradle of these raried creatures it has not been the place of their fuller cleselopment? The answer is plain, and in it we shall find some most important teaching. A common view of the action of natural selection is, that, given a full measure of increase and a fair share of 
variation, the struggle for existence will bring about a steadfast gain in the fitness of a form for the duties of life in its proper station, and that in time almost any measure of advance may be attained. But the failure of the marine forms to win their way to the organic and intellectual successes of the higher life is sufficient cridence that time and strugrgle, infinite toil and pain, ceaseless life and death, will not alone enable species to win the upward way. Many other conditions, which, in a question-begring manner, we torm the influences of environment, must enter into the inconccivably complicated equation which determines the fate of living beings. The struggle for existence has been as bitter in the seas as upon the land, it might well be maintained that it is far more intense in the water than in the animal realm, and it has endured for a reater time. What, then, is the reason for the lagging behind of the marine creatures?

It may well be that this slow advance, or rather, we should term it, this wide-spread failure of the aquatic life in all that regards elevation in structure and function, is duc to many different causes; but there is one cause which may, of itsclf, perhaps, in large part, account for the tardy evolution of the inhabitants of the sea. This is the imperfect nature of the breathing process which is inevitable in all truly aquatic animals. Marine animals necessarily depend for their process of respiration on the small amount of air which is clissolved in the water, a part of which they appropriate by means of their gills. The result is that in proportion to their size a gill-bearing animal, at best, has perhaps not the tenth part of the access to oxygen which is enjoyed by the ordinary land forms. Now, on the amount of this gas which comes in contact with the blood depends the share of nervous energy 
and muscular power of an animal: the force which propels their bodies or their brains is as much a matter of combustion as that which is generated in a steam boiler. This respiratory process is necessarily slow in all grill-breathers, which take the air from the exceeding dilution in water where it cloes not constitute one-hundredth of the mass, as compared with lungbreathers where the oxygen can be supplied as rapidly as needed. There is another condition of the sea which has, doubtless, much retarded the advance of its tenants: the greater part of its life dwells in utter darkness. It one hundred feet in depth the rertical sun yields only a twilight, and below one thousand feet it is perpetual night. As a large part of intellectual life depends upon the knowledge acquired by sight, we easily perceive that the utter darkness of the deeper sea is most unfarorable to the development of intelligrent beings.

With this understanding of the general limitations of marine life, we are not surprised to find that the animals of the sea are almost completely lacking in habits of an intellectual order. Save in a few forms, as, for instance. the species of fish which weave a rude nest of sea-weed, they make no constructions such as are so commonly produced by land animals. They rarely emit any sound in the nature of a sexual call; they never dwell in organized communities of a social sort; the sexes rarely if ever mate, even for a season. With them life in general has not risen above the plane of mere existence. The only marine animals which have been observed to have any distinct marks of intelligence are the forms which have the habit of resorting to the shore, especially the seals, which are descended from the land animals in the kinship of our bears and dogs; and are, in fact, not 
properly to be classed as marine animals, at least in their more essential qualities. There seems to be not sufficient nerrous energy to spare from the ceaseless turmoil of the combat which sroes on among the creatures of the sea, to afford the basis for intellectual development. All the small share of force which these animals with their scanty supply of oxygen can engender groes to the labor of tight and chase;

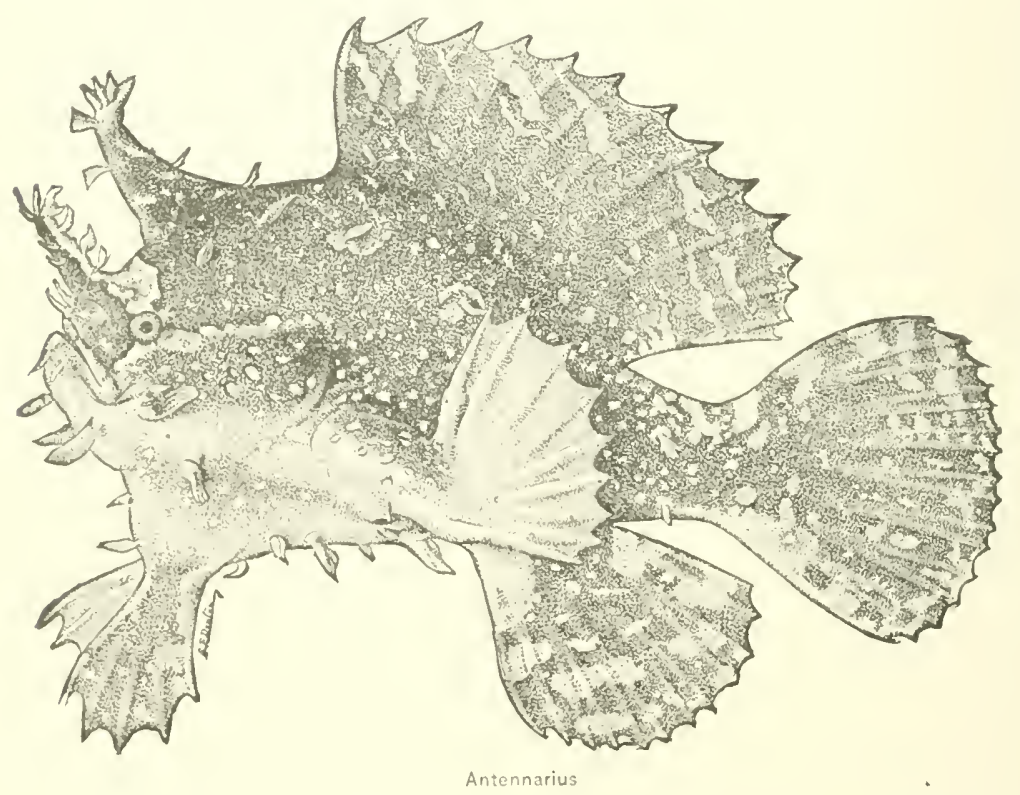

A creature related to our shore goose-fish, but adapted to live in water of moderate depth.

the ceaseless struggle to obtain food or to avoid falling a prey to their enemies. Although the mental processes of these creatures of the deep are limited, their physical growth is marvellously vigorous, and creates an amazing variety of forms, which are so far hidden below the veil of the waters that even the eager search of the naturalist has but imperfectly disclosed them. 
The immediate conditions of aquatic life differ in many important ways from those of the land. In the latter realm the weight of the animal or plant is not sensibly diminished by the buoyancy of the air; the result is that the creatures have in all cases to dwell mainly on the ground; even the most volant of the birds and insects spend the greater part of their days on the surface of the carth. The result is that the quantity of these land forms which can find a place for existence is determined by the room afforded by a shallow zone next the soil; the depth of this stratum is jractically limited between the bottom of the true soil and the top of the regetation which occupies its field; in other words, the stratum occupied by organic life on the dry land is limited in thickness to a few score feet, and in the vast treeless regions is but a foot or two in rertical extent. In the oceans, however, because the greater part of the creatures may frecly float or swim in the water, the realm which living things can occupy is vastly greater. It may extend from the surface downward to the depth of four miles or more. It is trus that the most inhabited sections are upon or near the bottom, and within a short distance of the top of the water; yet the whole of the deep is open to certain groups of beings, and probably has a share of occupants. The result is that, to each square mile of ocean surface, there are usually many times the number of individual beings which we find in an equal area of the land. As each of these creatures dies, eren if it live out its term of existence, its bodily parts are likely to become the food if many hungry mouths which are exactly adapted to the task of bringing its carcass back to the living state. Something of this same speedy conversion of the dead to the uses of life is seen upon the land; but what we see there affords but 
an imperfect image of the swiftness with which the translation

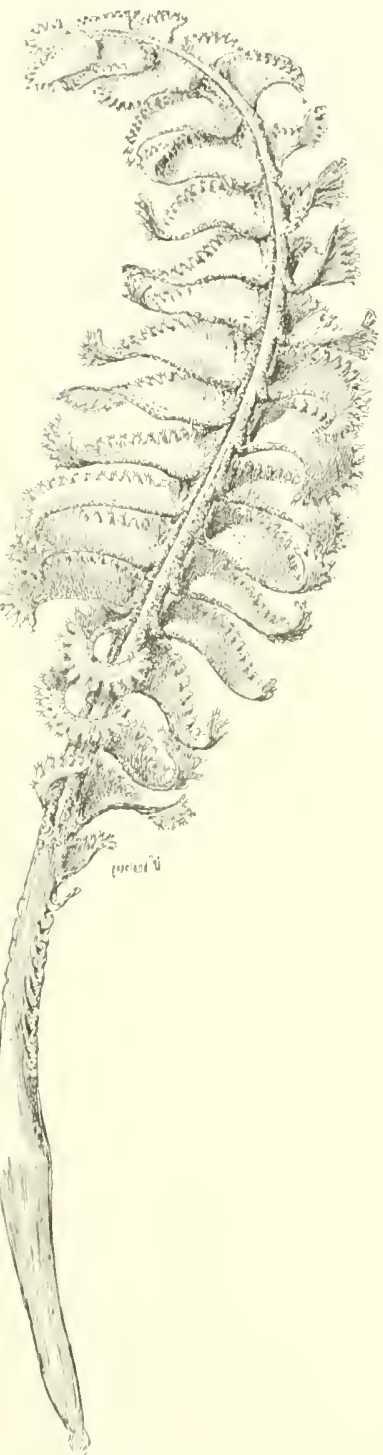

Figure of a Free Polyp Community, re. lated to the Sea Fans

Each little serration on the leaflets of the frond-like body is a separate individual. groes on in the sea.

The morements of the organic machinery in the deeper seas, unlike those of the land, are unaffected by the process of seasons. In the shallow water next the shore the summer's heat and winter's cold have some effect upon their tenants. In winter, at least in high latitudes, fishes, with rare exceptions, especially the schooling species, desert the shores, and many mollusks migrate into deeper waters; but in the profounder sea, where neither day nor night, summer or winter, brings any pause to the contest of life or any change in its conditions from age to age since these abyssal regions became first tenanted by organismsthe contest has been without any of these pauses of the winter sleep, which on the land is evident, even in the tropics as well as in high latitudes.

This continuity in the organic history of marine creatures makes it possible for a number of singular communities of animals to develop in its waters, the like of which are unknown in the regions which are 
enveloped by the air. In the latter realm all the animal species consist of separate individuals which may be associated in intellectual communities and colonies, such as those of the bees and ants, or in the herds of the herbivora or the flocks of birds; but in no case do we find them united by a physical bond. It is otherwise in the sea. 'There, many' groups consist of individuals which are knit together in the manner of the polyps and sponges; the several animals often

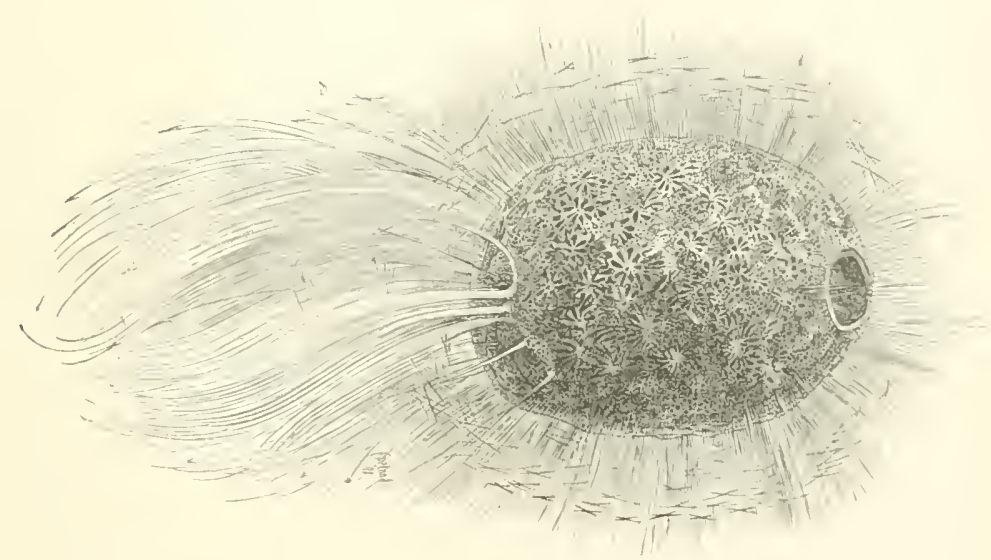

Figure of a Sponge, such as Inhabits the Deeper Parts of the Sea

to the number of millions combining their bodies to form vast organic associations, which may build the monumental structures of the fringing, or atoll reefs. This structural union in the life of the marine animals is paralleled on the land in the plants where many separate buds are associated in a single bush or tree, but none of the land animals have any such union of their bodies; such associations are possible in plants, even in regions where there is winter cold, because they become essentially lifeless while the frigid conditions prevail. It is easy to see that it would be quite impossible for the 
more highly organized amimal creatures to enter on such combinations in the open air.

Inother peculiarity in the environment of aquatic animals depends on the capacity of water for floating substances. All these forms on the land have to be endowed with the power of moving that they may seck their food, but in the sea the water floats the food to many waiting mouths, and the creatures may dwell fixed to the same place on the bottom from their birth to their death, waiting patiently for the currents to bring them their nourishment. All the corals and sponges, and nearly half the mollusks, obtain their supply of food in this manner; perhaps onc-half of all the marine species trust to this chance of gathering their aliment from the passing water.

For a century or more naturalists have known a great deal concerning the marine organisms which dwell in the shallow water next the shore. They long ago learned the amazing richness of these littoral forms. The census of species amounts now to more than one hundred thousand distinct kinds; it is, however, of late that they have ascertained that the deeper parts of the ocean-floors have also an abundant and varioc! poopling. Although the stucly of the abysmal life of the seas is but just begun, and the knowledge which has been gained is probably but a small part of that which will be wathered cluring the coming years, the results of the incpuries, in many wass, are not only most interesting, but in the highest degree important in shaping our views concerning the origin and history of organic life. These creatures of the abysmal regions of the ocean appear mainly to have been derived, by a process of variation, from those which once inhabited the shallower waters next the shore. 
The greater part of these shore dwellers are exceedingly intolerant of the enormous pressure of the deceper waters, as well as of the low temperature and total darkness which exist there. Certain forms have, however, acquired the ability
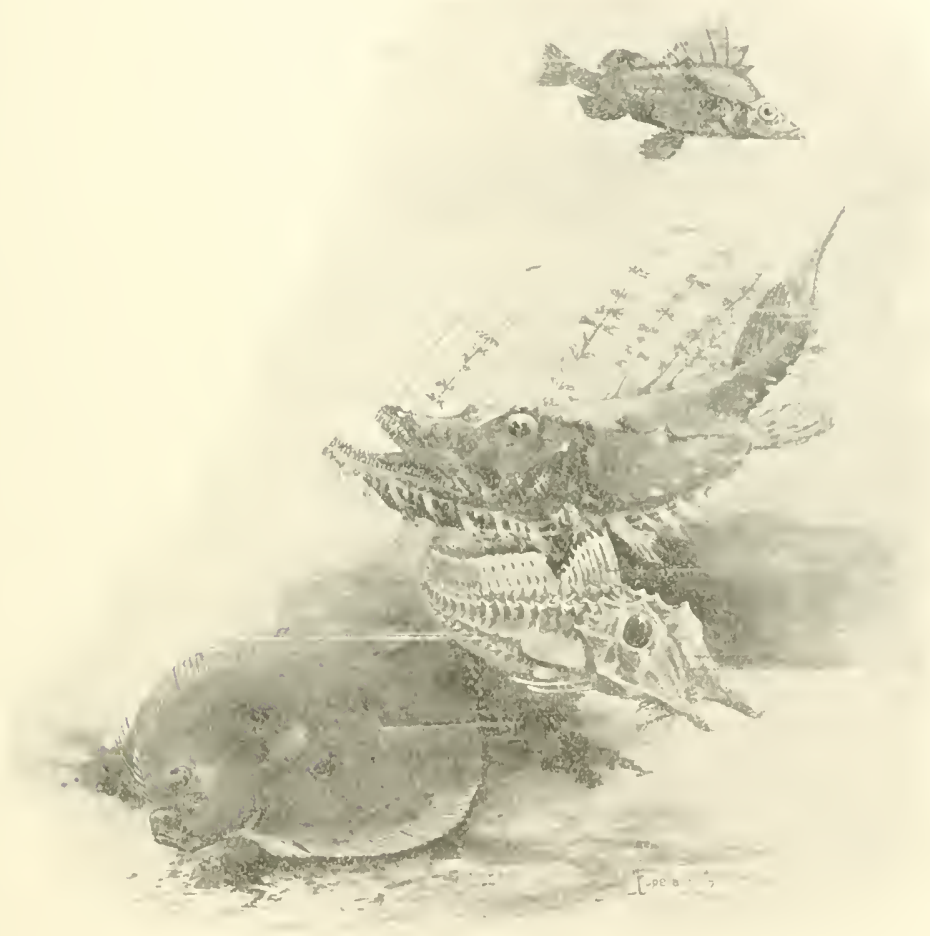

A G:oup of Fishes of Peculiar Form, such as Inhab:t $M$ de-ate Depths in the Sea

The bottom form is a flounder, with both eyes on the same side of the head to fit it for lying flat upon the bottom. The third from the base of the pleture is provided with fringed appendages which attruct the attention of its prey, and bring them so near that they may be captured in one leap.

to withstand these peculiar conditions; generation by generation through the geologic ages they have crept away from the realms of fierce combat next the shores, to the less contested fields of the open and deeper seas. Through all the 
reclogic ages this selection of especially prepared groups for the singular stations or habits of the ocean depths has been going on, with the result that those dark and pressureburthened regions are now tenanted by many cminently peculiar animals, by species which ever surprise the student who is accustomed to the forms which dwell only near the shores.

One of the most striking features connected with the

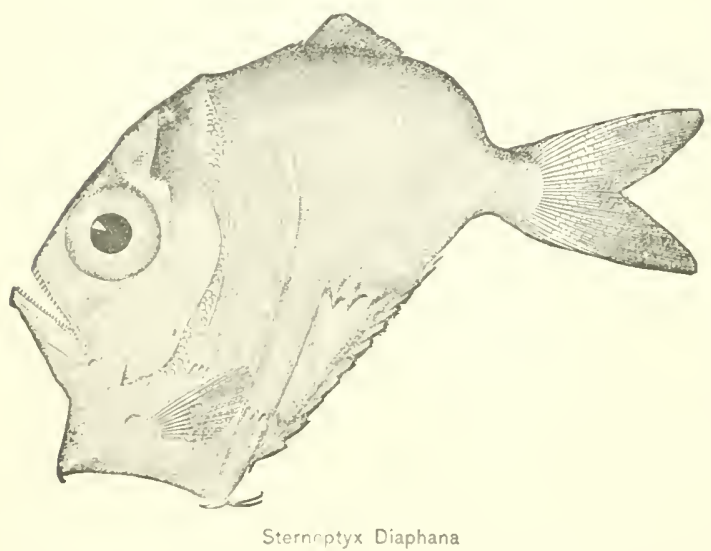

A fish of singular form from the open sea, and possibly inhabiting the greater depths. animals of the deep scas, is the frequency with which we find there living species which remind us of kinds which in former greologic periods dwelt in the coastal districts of the occans. It seem s that many of these a n c i ent creatures, when they no longer could hold their own against the more highly organized and developed animals which inhabited the favored stations next the shores, shrunk away into the deep water, and in that undesired part of the world found an asylum, where, amid the changeless environment, they have dwelt for ages, unaltered. Thus the vast profounds of the deep have become a sort of almshouse, whereunto antiquated species have retired before the overwhelming pressure which the newer and higher life ever imposes. From the results of the relatively trifling explorations which have, as yet, been made, there 
seems good reason to hope that in time we may win from the deep the nearest living representations of mary creatures which once occupied a large place in the seas, but now liave abandoned the fields of more active combat, which are usually the seat of the greatest advance.

In the profounder seas the invertebrate life appears to have a larger share than is secured by the vertebrate, or backboned animals; yet there are a number of fishes known in these depths, and it seems likely that these tenants of the deep sea may be numbered by thousands of species. Among the finned tenants of the deeper parts of the ocean, we find some startling departures from the types with which we are familiar in coastal waters. In general shape they cliffer little from their kindred which dwell in the sunlit shallows. The differences are largely in the mechanism of the senses, especially of the eyes. These organs undergo surprising variations with reference to the enduring of the darkness of these deeps. In certain of the species the sight not only fails, but the visual apparatus entirely disappears; in others the cyeballs become very much enlarged and the nervous apparatus increased; they are evidently arranged to catch mere glimpses of light. As it is certain that no trace of sunlight can ever penetrate through the deep which overlies the realm where these animals chell, the adaptation of these eyes to the needs of difficult vision at first appeared to be a very inexplicable matter. Some recent discoveries provicle us with what seems to be an adequate explanation of the cnisma. It has been found that certain of the denizens of the deep sea-floors have phosphorescent parts of their boclies which serve to give light in the manner in which it is yielded by the familiar fire-flies and glow-worms. The end secured by 
these light-giving parts is probably the attraction of the sexual mates of the creatures. In the utter darkness of the occan this indispensable end cuuld be so well attained in no other wy; even the fishes appear to have this beautiful provision for avoiding one of the most serious cvils of the darkness in which they arc compelled to exist.

It is evident that the fishes with large eyes would also have a decided advantage in the pursuit of food, for their

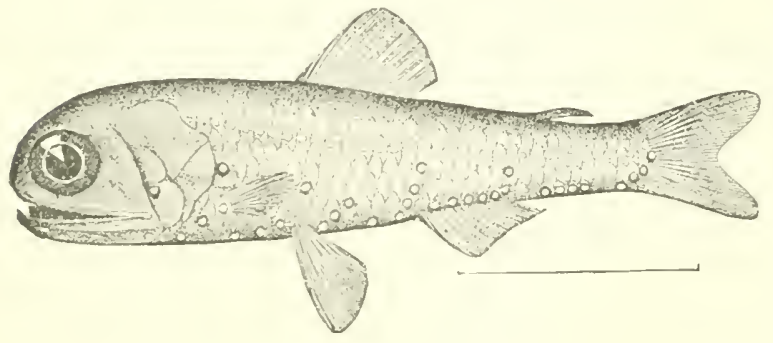

A Member of the Genus Scopelus

Showing the large eyes common in fishes which swim in the depths of the sea to which the light of the sun does not penetrate. The cyes are probably specially adapted to perceiving the phosphoreseent glow of varions animals. keen vision would enable them to discern the glimmer of the phosphorescent light for some distance through the still, clear water. The difficulty comes in the case of those fishes which under

the same general conditions of existence in darkness, combined with the same need of food, and of finding their mates, have not only failed to better their sight, but have abandoned it altogether. There is, perhaps, no other simple instance in which we may so well perceive the cardinal difficulty which the extreme selectionist encounters in his effort to explain all the complications of the ormanic world by the single: hypothesis of the survival of the fittest. Here are two sroups of like creatures introduced to the conditions of utter darkness after long ages of experience in the realms of light; under circumstances which, so far as we can perceive, are absolutely identical, the creatures enter upon widely diver- 
gent paths of variation. The lesson we may read in these facts seems plain; it is to the effect that environment alone is not always competent to determine the way followed by a species in its process of change.

In the sunlit regions of the surface of the open occans, even in the under water of the sea, down to the utmost depths to which the light penetrates, we have a zone of waters in which the variety of form is limited, and the greater part of them belong to the lower orders of being. From this part of the sea few fishes have been obtained, for the creatures are able to dwell only where there is an abundance of foocl. In this zone the most interesting forms are the lowly protozoa whose bodies, to the eye, appear as mere bits of translucent jelly, essentially unorganized, but which secrete shapely shells, showing that the apparent simplicity which they present to our eyes is due to our imperfect knowledge of them. Dwelling in myriads in the superficial parts of the sea, these foraminifera, as they are termed, sink at death to the bottom, over which they accumulate a thick coating of minutely divided limestone powder, forming a layer of ooze as unsubstantial as the finest snow. A large part of the North Atlantic, particularly that vast level tract beneath the central portion of the sea, known as the telegraphic plateau, because it was crossed by the first telegraphic cable which was laid, is corered with this chalk-like substance. Along with these shelly bits derived from animals which have dwelt near the surface. there go into the waste which accumulates on the floor, the remains of creatures which dwelt upon the bottom: thus it comes about that the fossils which we find in any stratum may have been nurtured under very various conditions: in part they may have dwelt on the floor of the deep sea, in the cold 
and dark waters of these regions, and, in part, in the tropical climate of its surface.

$11 \mathrm{e}$ have already alluded to the coldness of the water which is found at wreat depths beneath the surface of even the warmest parts of the open oceans. Wherever in such situations examinations of the temperature at the bottom have been made, it has been found to

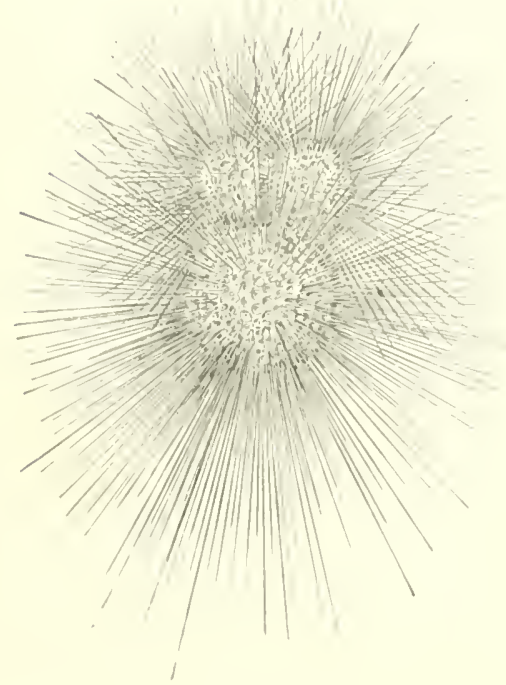

Globergerina

A member of the Foraminifera, a group of lowly animals which live in the superficial parts of the warm open sea, and whose remains fall in great quantities to the bottom. (Mtich magnified.) be very near the freezing point. There seems to be but one possible explanation of this sin. gular fact, which is the following, viz.: On the surface of the oceans there is a system of warm currents, such as the Gulf Stream, which flow in great volume from the tropics toward the poles. These tides of water have to be, in some manner, returned to the tropical districts. In part this is effected by certain counter currents which set southward along the surface of the sea; but the volume of these superficial movements flowing toward the tropics is small as compared with the streams which flow over the surface into the circumpolar seas. The principal return or compensating movement of the water appears to be brought about by a massive drift of the fluid which has been chilled nearly to the freezing point in high latitudes and then creeps, probably with extreme slowness, alongr the bottom until it may attain the equator. There, 
very gradually, it rises and takes the place of the part of the sea-water which has been driven away by the currents moving toward the arctic and antarctic regions. 'The prime movers of the superficial streams, like that which flows from the Gulf of Mexico to the North Atlantic, are the trade-wincls; and thus it comes about that the really arctic climate of the deep sea-floors of all the open oceans is caused by these wonderful permanent winds.

On the bottom of all the seas there is constantly gathering a coating of materials clerived from the bodies of animals and plants which perish there, or which fall down upon the floor from the higher parts of the water; with this is mingled, more or less finely divided rocky matter. If the portion of the submarine surface where the accumulation is making is near the coast line, these sev-

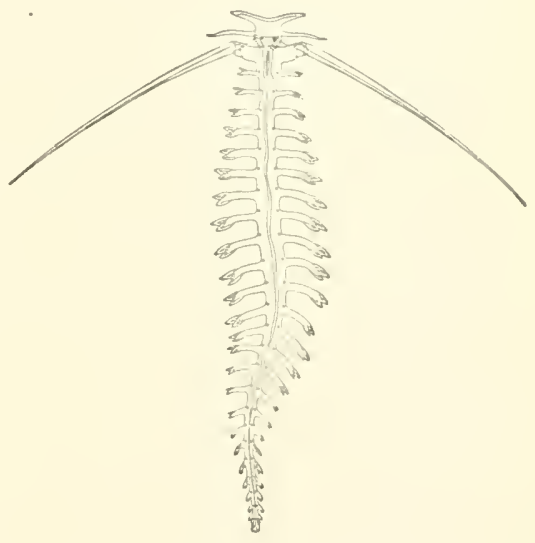

Tomopteris

A curious worm-like animal inhabiting the surface of tropical seas. eral mineral substances may be derived from the land and brought into the sea by the rivers or dragged away from the beaches by the reflux of the tides. In high latitudes the icebergs raft off from the land quantities of stony fragments which, when the ice is melted, fall swiftly to the bottom. But this importation of detritus from the continents can affect but a small portion of the ocean-floors: it is probable that the greater part of the sediment, other than that derived from organic remains which come to rest on these surfaces, is thrown out from volcanoes. The amount of these cjections 
from active craters is very sreat. It secms certain that in a little over a century the volcanoes of the Javanese clistrict alone have cast into the sea not less than one hundred and fifty cubic miles of clust and pumice. As this matter contains a good deal of gas in the form of small vesicles, it may float to a great distance and undergo much chemical change before it finally comes to rest on the ocean-floor. Each bit of this pumice or ash may indeed journey all the world about before it is decayed and falls to pieces or is weighted down by the small animals and plants which adhere to its surface. The quantity of this igneous matter which is cast into the sea is probably far greater than that brought down to the deep by all the rivers, and in volume the contribution is probably only exceeded by that which is worn from the shores of the sea itself by the action of the wares and tides.

In the endless procession of fragments which are brought to the ocean-floor by the very varied actions which lead, in time, all things clown to its depths, there perhaps to await their far-off resurection into continents which are yet to be, we must rechon the remains of man himself; the debris of his body and his arts which strew that portion of the earth hidden from our eyes by the sea. There is a rather common, but erroneous notion, to the effect that a human body, or even a ship, will not sink to the bottom of the profounder abysses of the oceans, but will, on account of the clensity of the waters at a sreat depth, remain suspended at some distance above the surface of the earth. This is an error. No other fate awaits the drowned sailor or his ship than that which comes to the marine creatures who die on the bottom of the sea; in time their dust all passes into the great storehouse of the earth even as the ashes of those who receive burial on the land. 


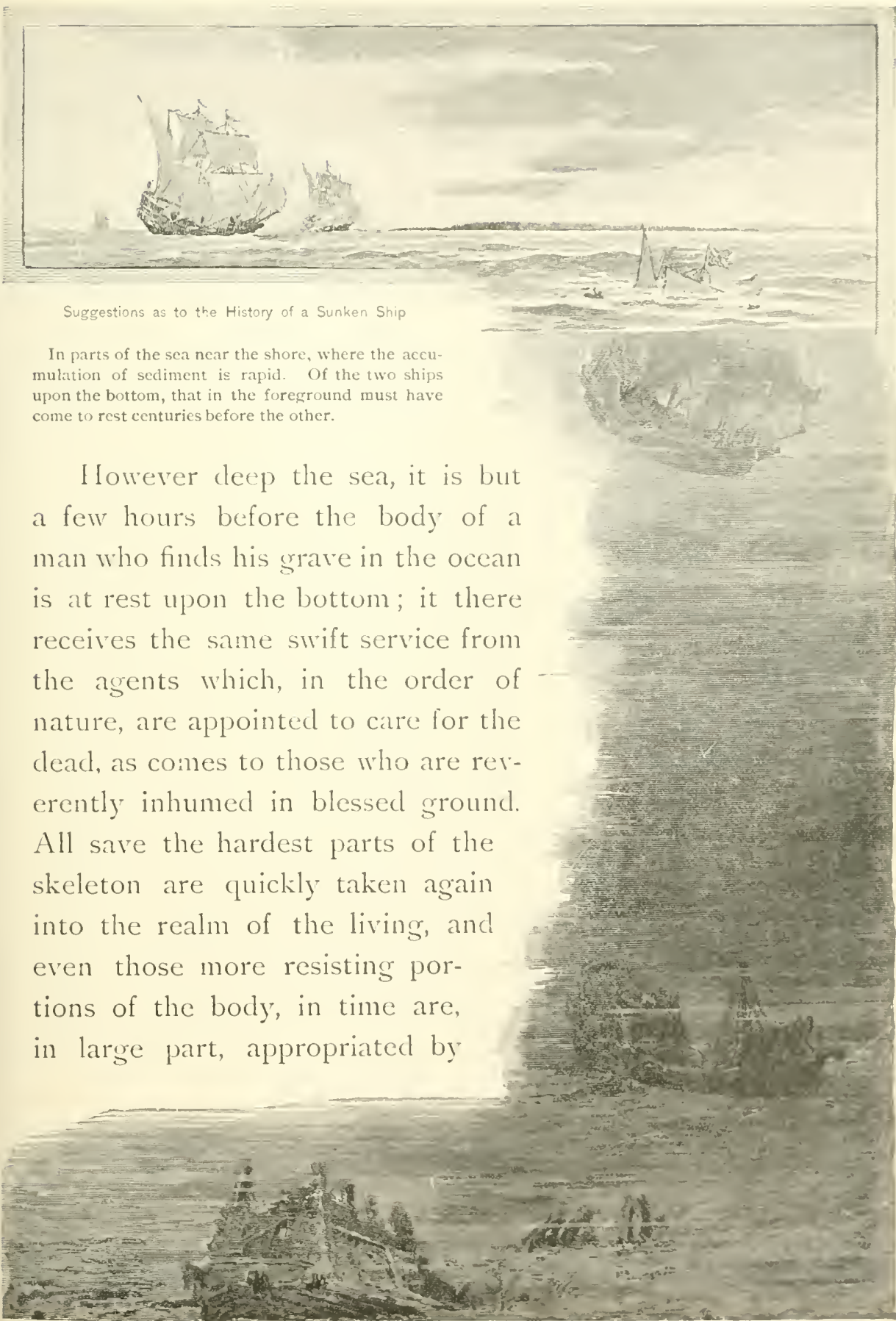


the creatures of the sea-floor; so that before the dust returns to the firm-set carth it may pass through an extended cycle of living forms.

The fate of animal bodies on the sea-floor is well illustrated by the fact that beneath the waters of the Gulf Stream, where it passes by southern Florida, there are, in some places, quantities of bones, apparently those of the manitee, or sea-cow, a large herbivorous mammal, which, like the seal, has become adapted to acpuatic life: these creatures plentifully inhabit the tropical rivers which flow into the Caribbean Sea, and are, though rarely, found in the streams of southern Florida. At their death they drift out into the open water and are swejt away to the northward by the ocean current. For some weeks, perhaps, the carcasses are buoyed up by the gases of decomposition which are retained by their thick, oily skins; as these decay and break, the bodies fall to the bottom. When the dredge brings up fragments of their skeletons we find the bits bored through and through, like insect-eaten wood, by the many animals which are fitted to consume them. It is evident that in a short time these bones become reduced to powder.

It is otherwise with the ships which founder in the deep sea. 'They doubtless remain for centuries as monuments of the strange doings of the masterful creature of the land. Whatever the attitude of the craft when it is overwhelmed by the waters, it is likely that a moment after it descends below their surface, it rights itself, assuming the position it occupies when sailing in quiet waters. The weight of the ballast necessarily brings it into this position. In this attitude the vessel falls steadfastly, but not very swiftly, until it strikes the bottom. It may require in the average depth of the sea, which 
is about three miles, a quarter of an hour or more before an ordinarily laden wooden ship finds its long resting place. 'The blow with which it strikes the sea-floor is not likely' to dismast the ressel or to wreck its hull; the shock usually comes upon mucl-like materials, sufficiently yielding to give a little to the blow, so that the violence of the contact is diminished, and the upright position and integrity of the hulk may be maintained.

As soon as the sunken wreck is at rest we may imagine that it becomes the subject of careful inquiry on the part of a host of hungry creatures who await such wind falls from above. Penetrating the spaces of the hold they make avail of all that can serve them as food. More slowly certain forms, which bore in wood, will honeycomb all the timber until the beams and planks are reduced to mere shells. At the same time a host of species which have the habit of attaching their living skeletons to any firm support, crust over and festoon with their bodies all the external parts of the wreck, and serve to bind the frail structure together. In the course of time the fabric becomes a mere ghost of a ship; it holds together only because the ocean is perfectly motionless, and its parts are buoyed up by the water about them. In the course of ages the weight of the incrustation increases, so that at last some part is borne down, and through the shock which this causes the shadowy relict may at once melt into clust.

We must conceive a somewhat different fate for the modern iron ships which find their last haven in the quiet waters of the ocean-floor. Because of their greater weight they will fall more swiftly and strike with greater violence on the bottom. They are, on this account, more likely to be ruined by the last blow they are to receive. Moreover their 
iron sides and beams afford no food to the marine animals; nevertheless they are attacked by the sea-waters, and their ciecay probably proceeds so rapidly, and the gravitative energy of their metallic parts is so great, that they more quickly fall into ruins, which can hardly be as picturesque as those of the olcler type of ressels. It is cloubtful if the wrecks of any of the modern men-of-war which have foundered at sea will hold together for fifty years, while those sunk cluring the action of 'Trafalgar may endure for centuries in the grim semblance of battle ships.

The idea that ships are likely to be buried in the accumulations which are forming on the deeper sea-floor, rests upon a mistaken conception as to the speed with which sediments are laid down at a distance from the shore. These deposits of the open occans are so slowly made that we must deem it excessive to suppose that a depth of a single inch can be formed in a thousand years. It is likely that in no case, save near the coast-line, or in the rare places where the showers of volcanic waste bring an unusually large amount of detritus, can a ship be buried in the accumulating strata so as to be preserved in a recognizable form. If the creatures of the far future, to whom it may be given to scan the rocks which are now forming and are hereafter to be uplifted into dry land, are to find a trace of their remote ancestors in the deposits, they will secure it, not by discovering the hulks of great vesscls, probably not from the bones of men or the common implements which serve them in seafaring, but from the ebjects composed of slass, or more likely those made of the rarer metals such as gold and platinum. Of the rast wreckage of an iron war-ship such as the "Captain," which sunk in the Bay of Biscay, the hulk, great guns, shot, and shell, the 
timber, and all the forms of its crew will probably disappear before they are entombed in the slowly gathered strata. The geological remainder will perhaps be the coal of her fuel store, the gold of the watches and trinkets, and the massive glass objects which abound in such a ship; in all but a small, and little indicative, part of what went to the bottom of the sea when the ressel foundered.

It has, to many persons, been an interesting speculation as to the aspect of the countless wrecks which have becn swallowed up by the North Atlantic since that churn of waters has been ploughed by the keels of ships. Their number is probably to be reckoned by the tens of thousands, and the greater part of them lic in a comparatively small part of that field. If we count this portion of the Atlantic which is most peopled with wrecks as having an area of 3,000,000 square miles, and estimate the total number of such ruins within this space as 30,000, we would have an average of one sunken ship for each hundred square miles of surface. If all these crafts were at once sailing over the surface of the sea, we should, from the deck of any one of them, be likely to note the masts of several others. But as they lie on the floor of the ocean the greater part of them are probably reduced to low mounds of rubbish. so that if the ocean-floor were converted into dry ground, and we crossed it in a railway, seeing the fields as we lo the prairies, it would require an attentive eye to discern the existence of many of these remains.

It is a singular, and perhaps somewhat humiliating fact. that the most conspicuous and indelible record which man is making in the strata now forming on the sea-floor is written in the bits of coal and ash which are cast from our steamships as they pursue their way over the ocean. The quantity of 
this debris is very great, and unlike the wrecks it is very evenly scattered along the paths followed by our steam marine. It is likely that already in the track of our transatlantic commerce, not a square rod would fail to give a trace of this waste from our coal-burning engines. As this material is not attacked by the marine animals, and is but little affected by the other agents of decay, it will doubtless be very perfectly preserved in the strata which are to bear the records of our time. 


\section{ICEBERGS}

Effect of Expansion of Water in Freezing.-Classes of Ice-Fields.-Origin of Ice-Floes.-

Migrations of Ice-Floes.-Origin of Icebergs.-The (ireenland Cilacier.-Annual Product of lcebergs: their Voynges; their liffect on the (Jean; the Urder of their Movements; their Decay; their General Influence on (limate-Transportation of Rock Débris by Icebergs.-Effect of lce on shores.-Iceberg Work in Former Geological I'eriods.-Dangers to Ships from Collision with lcebergs.

Much has been said by optimists concerning the many advantages which arise from the simple but most exceptional fact that, while all other substances contract, water expands in passing from the fluid to the solid state. The consequences of this peculiarity are indeed not overstated by those who take an excessively pleasant view of man's relations to the world about him, for the simple reason that it is not easy to exaggerate the beneficial effects which arise from them. If water did not depart from the general law that substances occupy less space in their solid than in their liquid form, the ice on our seas and lakes would, as fast as it formed, sink to the bottom, so that all the oceans and other water-basins in high latitudes would normally be frozen to their floors, except when the summer's heat had melted a thin layer next the surface. If it were really worth the while to theorize concerning things which are out of the present order of nature, we might casily show that such a condition of affairs would make the earth essentially unfit for the uses of civilization. It will, however, be more profitable to consider the points which the pessimist might take, if his ever-smiling adversary 
pressed the profit arising from the fact that water expands, in freczing, too far for patience to endure; to show, in a word, the list of considerable disadrantages which arise from this law, which serve indeed, in some part, to countervail the biessings it brings to us. In his argument he would have to depend in the main upon the dangers which arise from the ice which drifts from either l'ole into the parts of the sea which ships need to traverse, bringing with them an atmosphere of fors, which, rendering the floating islands almost invisibie, adds much to the risks of navigation. These ice-masses not only endanger vesscls, but they chill the waters of the sea in such a measure that, by the cold and misty air which sweeps thence upon the land, extensive regions, like the island of Newfoundland, are made unfit for agriculture. These migra. tions of iccheress are manifestly due, in the main, to the fact that ice floats; if it sunk, whatever other costs this condition entailed, there would be no wandering ice-fields in the scas.

To understand the conditions which lead to the existence, eren in midsummor, of floating islands of ice within the warm northwarcl-setting waters of the Gulf Stream, it is necessary for us to consider many facts concerning the natural history of ice, and the physical condition of the regions from which these bergs are clerived, as well as that of the districts through which they journey to the central portions of the North Atlantic; fortunately for our purpose, all these facts are very interesting, and some of them are of the most picturesque features which the aspects of this world afford. The biography of an iccberg brings us in contact with the frozen rexions about the Poles, and with the marvellous ocean currents which transport the tropical waters to those regions, and with those other streams which send, in return, waters of 
nearly freezing temperature down toward the equator. The simpler phenomena of freezing and frozeir water, which we shall incidentally have to consider, are attractive parts of the science of physics, for the reason that they are easily comprehended and are well illustrated by familiar and personal experiences.

The ice which travels from the Arctic regions toward the equator consists of two very different kinds of masses, the difference being so plain that they are invariably recosnized by all observers; in part they are made up of flat or tabular masses, which seldom if ever have a thickness of more than one hundred feet even before they have begun their journey to lower latitudes. Though limited in depth these fields of floe-ice, as they are commonly termed, often have a great horizontal extension. Near the southern extremity of Greenland they sometimes have an area which is to be measured by square miles. Though interesting, these floes have less economic or geographic importance than the group of true icebergs, for the reason that they do not journey so far from their point of origin, and rarely come into the ordinary paths of commerce. The true icebergs differ from the ice-lloes in that they are vastly thicker and do not liave the same tablelike tops, but are usually serrate at their summits. It is impossible to determine by actual measurement the depth of the ice in the true berg, but we know from the specific gravity of frozen water that only about one-seventh to one-ninth of their mass rises above the level of the sea, and we can safely infer from the extent of the emerged portion that their bases are often two or three thousand feet below the surface of the ocean. This estimate, though it does not need confirmation, is fairly proved by the fact that many bergs have 
been observed to run aground in water of this depth. These great variations in the proportions of bergs and floes afford a fair presumption that there is some essential difference in the origin of these two classes of ice-islands. A glance at

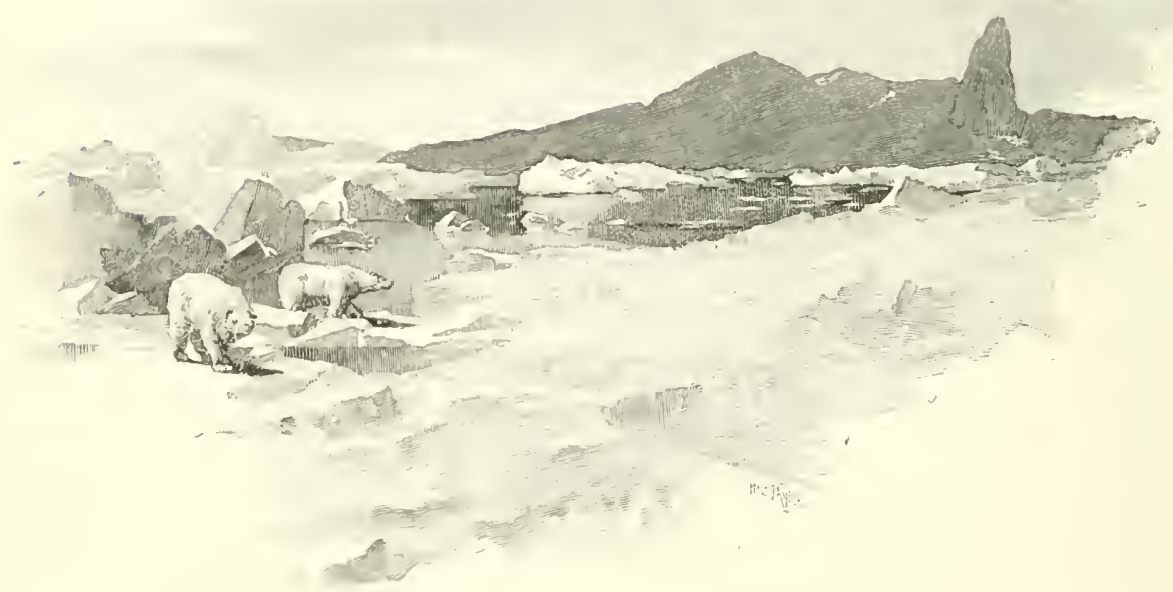

View on the Coast of Greenland

Showing small bergs intermingled with floe ice, with polar bears in foreground

the processes by which ice is made in high latitudes will show us that this hypothesis is amply justified.

When the Arctic explorers or the whalers make their way to the fringe of small settlements which lie upon the western margin of Greenland-the only part of that vast area which is ever indeed green-they usually begin to encounter the floc-ice, and as they go northward it increases in thickness and in the extent to which it obstructs the surface of the sea, so that the ships are compelled to creep through the rifts 
between the ice-fjelds, the narrow lanes of water which, now opening, now closing, afford most perilous and difficult ways to the higher north. Finally, where the western shoulder of Greenland and Grimnell Island narrow the passage which leads into the Arctic Sea, the ice is so firmly held together that it has never been found sufficiently fissured to afford room for the passage of the smallest boats. Thence on to the long-sought but apparently inaccessible Pole, the sea is covered with a connected sheet of ice, the upper surface of which is exceedingly rough and hummocky, so that it is impassable for sledges. The rast region covered by this sheet of floe-ice, which probably has a depth of one hundred feet or more, has been termed the Palceorystic Sea, or the Sea of Ancient Ice. It is clear that its envelope of frozen water is but a more consolidated area of sheet or floe accumulations-in other regards exactly like the flelds which float out of Davis Strait and move down the coast of Labrador until they invade the Straits of Belle Isle, and through this channel penetrate into the Gulf of St. Lawrence or crowd into the inlets of northern Newfoundland.

It is evident that the origin of this floe-ice is as follows, viz.: In the long winter of high latitudes the surface of the sea, wherever it is not affected by the warm waters of the south, freezes so that a considerable depth of ice is made. A single winter will often accumulate it to a thickness of ten feet or more. In the short summer this ice only in part melts away, and the next season adds still more to it. IIhen the sheet breaks up into separate fields, these masses, often square miles in area, are set in motion by the tidal currents or the strong winds; they collide with each other and with the shore, and by these accidents the cakes of ice are shoved 
over and under each other, thus thickening the floes in a very rapicl manner. As soon as these calies of ice come to rest in their new position, they are solclered together so that the floe is a solid mass which may drift away for great distances in the control of the winds or the shallow currents of the sea. So massive are they, indeed, and so vast in number and area, that but for the nature of the current systems of the North Atlantic, they might greatly embarrass the main line of ship trarel between the northern parts of Europe and those of the northern United States and Canada; but the direction of their southward migration is, as we shall now note, greatly affected by the ocean currents.

All the superficial parts of the western Atlantic, except the portion of its area next the coast of America, are pervaded by a slow movement which sets the water toward the Poles. This curreint is due to the Gulf Stream, which, emerging from the tropics as a deep, narrow, swift-moving tide, skirts the southern coast of the United States, gradually widens like an opened fan, diminishing in depth and losing its relocity as it comes toward the Aretic Circle. Although the speed of its northward going is here slight, it has sufficient energy to push back the floe-ice which may be driven southwardly by the winds, and thus limit its excursions to the American shore. Setting out into the Atlantic from Davis Strait, there is, however, a strong stream of Arctic water, which in part slips under the Gulf Stream tide, and in part flows on the surface of the sea next the Labrador coast. In this southward-setting current the floe-ice drifts with a speed of about a mile an hour down the American shore until it attains the mouth of the St. Lawrence. The Labrador current, as this southward-moving water is called, would, but for certain accidents of geography, 
send this floe-ice much farther to the southward than it now does. If Newfoundland and Nova Scotia should disappear, so that there could be a nearly straight shore from Greenland to Massachusetts Bay, it is likely that these floes would in large quantities attain to the coast of. New England, and sive to the shore lands of that part of the continent the sub-Arctic and inhospitable climate of the islands of the eastern St. Lawrence. This shore current bears few true icebergs with the Hoe-ice, for the reason, as we shall see more clearly hereafter, that these greater ice-islands are formed altogether on the Greenland shores, and, pressed to the eastward by the prevailing winds, do not come into that superficial, shore-skirting, Labrador current. Moreover, any stray bergs that may find their way against this margin of the mainland are almost certain to take the ground in the shallows over which the current passes, and so be arrested in their journey.

The character of the ice-floes, as well as the steadfastness of their southward journeys, are well shown by the singular experiences of a part of the crew of the exploring ship Polaris, who, in 1872 , were forced to abide for several months on these ice-rafts. The ship was in close quarters in the ice-pack of Baffin's Bay, and was pinched between the floes with every prospect of being crushed like an egg-shell between the moring masses; the crew, with supplies of provisions and boats. were encamped, in two separate parties, on the ice near the distressed vessel. A sudden change in the movements of the ice caused the floes to separate, and one of the parties was swiftly borne away from the ship, which, indeed, they thought had sunk from the strains she had received in the squeezing between the packs of ice. The forlorn party', consisting of a score of sailors, several Esquimaux men, two women, and 
several children of that people, drifted away to the southward, and for the time between October isth and April 29th found refuge on the floe-ice, and were carried onward toward the open Atlantic. As they came into the wider waters the waves swept over the flat surface of the ice and broke the original wicle fielel into small patches, each a few acres in extent, so that they had from time to time to select a new refuge. Their sufferings were consiclerable, but with the courage and hopefulness characteristic of our sailors, they undauntedly met their difficulties, each dutifully caring for the other, so that when rescued by a passing ship every member of the party was alive. The chronicle of this wonderful adventure is one of the most picturesque stories of bitter experience and fortitude which the literature of Arctic adventure afforcls.

In the regions about the Southern Pole, because of the vast area of ice which is gathered there, the climate in summer is much less calculated to melt ice than in the region about Greenland. The large area of this southern ice-cap is caused by the failure of the warm currents from the tropics to attain the Antarctic Circle; this is brought about by the absence of any distinct land-bounded pathway of the waters, as exists in the North Itlantic lands, which, in a way, serves to confine the Gulf Stream and lead it to the Arctic regions. Noreover, the southern currents, which are diverted toward the Antarctic Sea, are less strong than those which flow northwardly from the equatorial parts of the oceans. Owing to the fricrid condition of the summer climate of the southern ice-district, and the absence of warm water to melt the ice, the floes of that region are thicker and form more extended fields than those with which explorations of the Greenland district have made us acquainted. Fortunately there are in the Antarctic district 
no such strong currents as those which sweep down the shores of labrador to convey these packs of ice to the parts of the sea which are most traversed by shipping; they are rarely encountered cxcept by the whalers or the rare explorers who have attained to these lonely waters of the far southern seas. We have now completed our general account of the simpler and least important of the groups of floating ice-fields. IVe have next to examine into the processes which lead to the formation of the far grander masses, the true icebergs.

We have already noted the fact that icebergs differ from floes in that they are far greater in depth; it is also characteristic of them that they are composed of a dark blue variety of ice, which is generally much more solicl than that of the floes. The berg-ice has also the peculiar feature that it tends to rift in a vertical direction, which gives their crests the striking and beautiful outlines so characteristic of them where they have been much decayed by long exposure to the warm air of the region of the sea to which they attain near the end of their journeys. To understand these peculiar features it is again necessary for us to consider the regions where these icemasses are formed. It is now well known that all true bergs -and in this class are included all the floating masses which find their way down to the line now followed by the transatlantic steamers-have their origin in the glaciers of high latitudes. Those which beset the pathway of ships moving from Europe to America are all cradled in Cireenland. All the lands north and west of Spitzbergen are more or less occupied by fields of perpetual snow, which, slowly descending the valleys, is by pressure and by its forward movement converted into pure translucent ice; all the little cavities containing vesicles of air, which gives to snow or powdered ice 
its white color, become closed as the air escapes during the onward journey of the stream. In more southern climes, as in Norway and Switzerland, these glaciers in their descent meet a climate sufficiently warm to melt them away before they attain the level of the sea; but in the greater part of the lands within the Arctic Circle there is at the sea level an annual average temperature below the freezing-point, so that any glacier which is formed moves on until it thrusts its extremity into the sea.

For a time after the slow-moving stream of ice enters the ocean waters, its height causes it to continue to rest on the bottom; but when it penetrates to a certain depth of the sea, a depth depending on the thickness of the ice-sheet, the buoying action brought about by the relative lightness of the ice tends to lift it from the bed over which it has ploughed. As ice, though easily mobile under pressure, as the movements of the glaciers themselves clearly show, is very brittle to any cross strain, such as this tendency to float imposes, the cxtremity of the ice-stream is continually broken away, forming detachable masses. The resistance of the ice to fracture catuses the projecting extremity of the glacier to hold together for a little distance beyond the point where the weight of the mass alone would hold it upon the bottom. When the berg separates from the parent mass, the rupture is attended by a violent movement, often causing a loud thundering noise which may be heard for many miles. The rebound of the newly freed mass from the bottom and the firm-set glacier whence it came, causes it to swing violently, so that it sends great waves sweeping from its base out into the sea, which, though on a larger scale, are like those produced when a ship is launched. The Esquimaux are so familiar with this process 


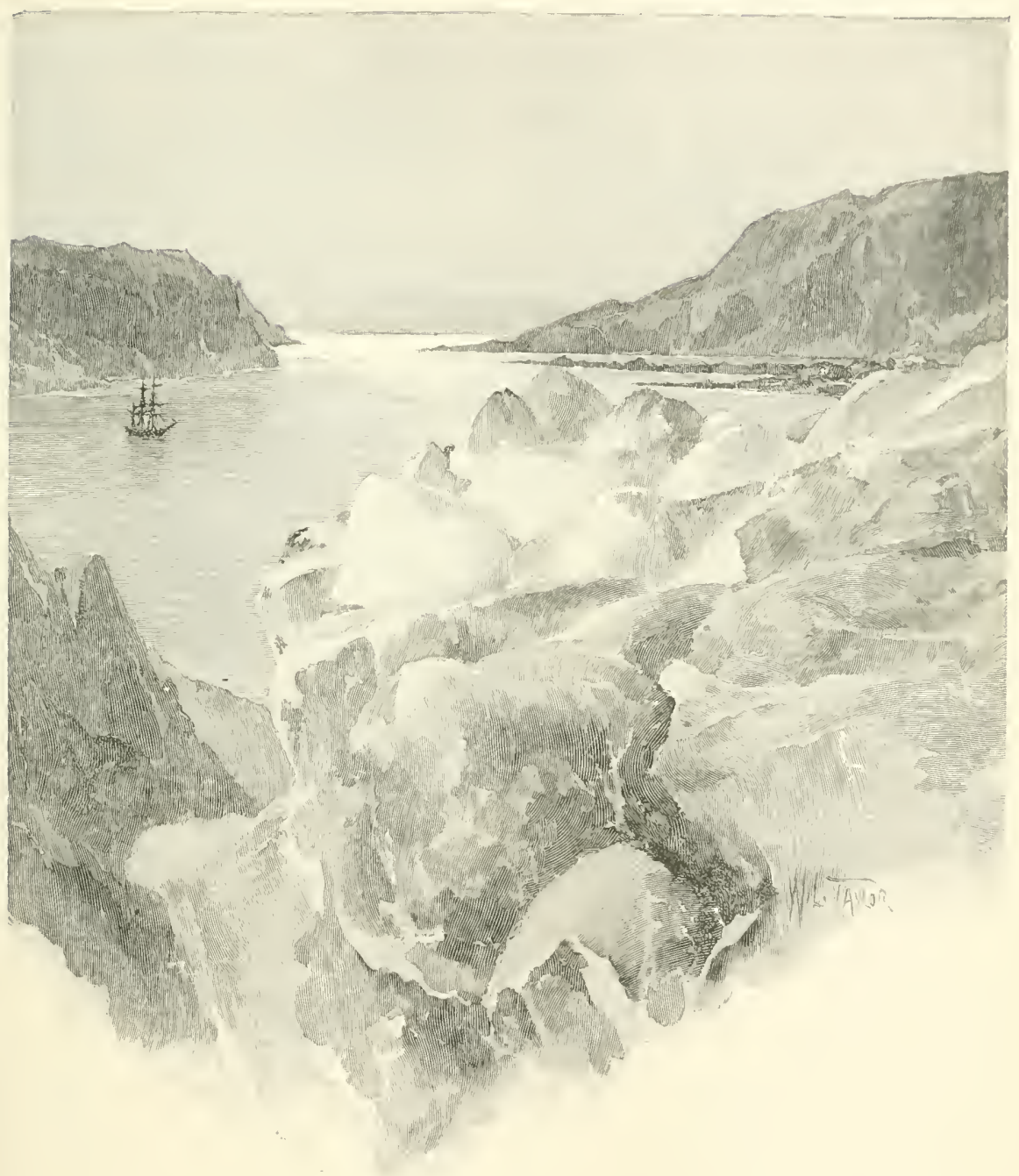

View of the End of a Glacier at the Head of a Greenland Fiord

During the recent greater extension of the ice the stream filled all the vallcy enclosed in the field of view and overtopped the neighboring mountains.

of separating bergs from the land-ice, that when they hear the roar which it causes they say the glacier is "calving," or giv'- 
ing birth to its young. By this savage description they secm to indicate, in the manner common to primitive peoples, their sense of the activity which exists in the glacial streams, as well as that perception of life in nature which, though a common feature with uncirilized people, disappears with the advance in culture.

Greenland is the great source whence the icebergs of the North Atantic are "calved," and the physical conditions of the country make it admirably fitted to be the breeding-place for those monsters of the deep. Until very recently our knowledge of this country was limited to the southern extremity of the island and the narrow strip along the western shore, where there are a few villages which are visible from a ship's deck. The eastern shore is so blocked by floe-ice that few mariners have seen the mainland for more than a hundred miles beyond its southernmost part. It has long been known, however, that along the whole coast-line the glaciers descend to the heads of the inlets or fiords which plentifully intersect the shore. Both on the east and the west the ice-streams are so deep and massive that they override the whole marginal portion of the country, hicling its irregularities in the vast shect of the glacier, which sweeps into the sea until it attains a depth where the ice breaks off and floats away in the form of icebergs. 'The greatest of these ice-fronts, that of the Humboldt Glacicr, faces the water in the upper part of Baffin's Bay with a continuous precipice of ice having a length of about fifty miles. So far as is yet known, this is the largest of the Greenland berg factorjes, but it is possible that even greater protrusions of the central glacial field may occur on the eastern coast.

There has long been much natural curiosity concerning the 
aspect of the interior district of Greenland, for naturalists have felt that we should there secure much valuable information concerning the conditions which existed during the glacial period over a larger part of Northern Europe and North America. Many travellers have ascended the ice-streams for a little distance, and have looked inland apparently upon fields of snow. Recently some bold travellers, properly equipped for traversing the ice, made their way to the eastern shore of Greenland, and started on a hazardous journey with the western shore for their destination. After passing for some miles over a portion of the glacier, which was much broken by crevasses-due probably to the existence of irregularities in the floor of rock over which it was moving - they gradually ascended until they came upon a vast, unbroken surface of ice, which was apparently as level as a frozen sea, and which stretched away beyond the field of vision. This portion of the continental glacier, the first ever seen by civilized man, rose gently until, by the barometers, it apparently attained a height of about a mile above the sea. Thence it cleclined with a grade so slight as to be invisible to the eye until near the western shore, when it descended more steeply, and was broken by rifts, as the travellers found it at the outset of their journey.

This vast arch of ice doubtless occupies all the surface of Greenland except the narrow belt next the shore, mainly on the southern and western coasts, where the higher land is now left bare. It would be most interesting to consicler the general conditions of this wonderful glacier, with reference to the state of affairs during the last frozen period, for there can be little doubt that we have in the region beheld by these hardy explorers a very true picture of a continental ice-sheet, such as 
in a recent geological age covered the eastern part of North America as well as much of the Old W IVorld. But for our immediate purpose we need only to note the immense extent of this ice-ficld, its great depth, and the speed with which it moves from the interior toward the sea. So far we have but imperfect clata concerning the rate at which the high northern gracier passes from the land into the sea; but it is clear that the movement is much more rapid than in the case of the relatively small ice-streams of the $A l_{p}$ s. In the valley glaciers of Switzerland, Norway, or the Himalayas, the speed of the flow does not excecl on the average more than three feet per diem. At the bers-making fronts of Greenland it probably amounts on the average to more than thirty feet per day; that is, a strip) about half a mile wide would be fed into the sea in the short summer season, and if the flow was maintained during the whole year, there would be a field nearly two miles wide discharged as floating ice along the whole front of the streams which attain the sea. There is no satisfactory basis on which to estimate the linear extent of the glacial front on the Greenland shore, but it is probably not less than two hundred and fifty miles. If this be the size, we may reckon that somewhere near five hundred square miles of icebergs is each year set afloat along the shores of the island. Supposing that the original area of these masses was one-fourth of a square mile, this supply would provide for a yearly fleet of two thousand bergs, from which throng the ice which our Atlantic ships encounter is derived.

The history of these bergs, after they have become separated from their parent glaciers, has not yet been carefully traced. It is evident that a large part of them never attain to any considerable distance from the coasts where they were 


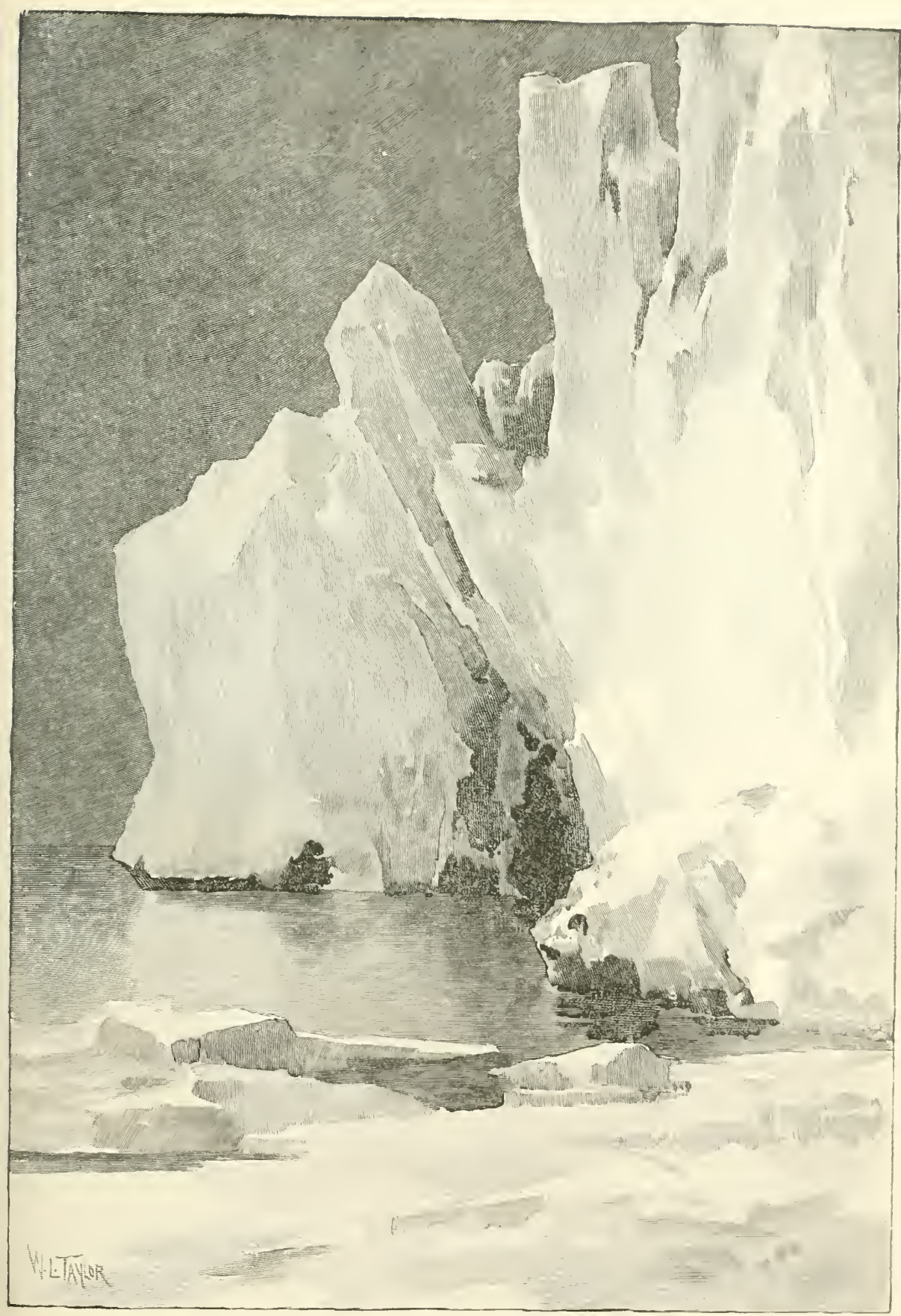

View at the End of a Glacier, showing an Iceberg just ready to Separate 

discharged into the ocean. Those which are launched in the inlets are apt to be retained by the shores and melt before they escape to the sea, of those which start on their journey many become stranded on the shallows, and break into small pieces, so that they are rapidly melted; yet others, including probably nearly all which are formed on the eastern shore of

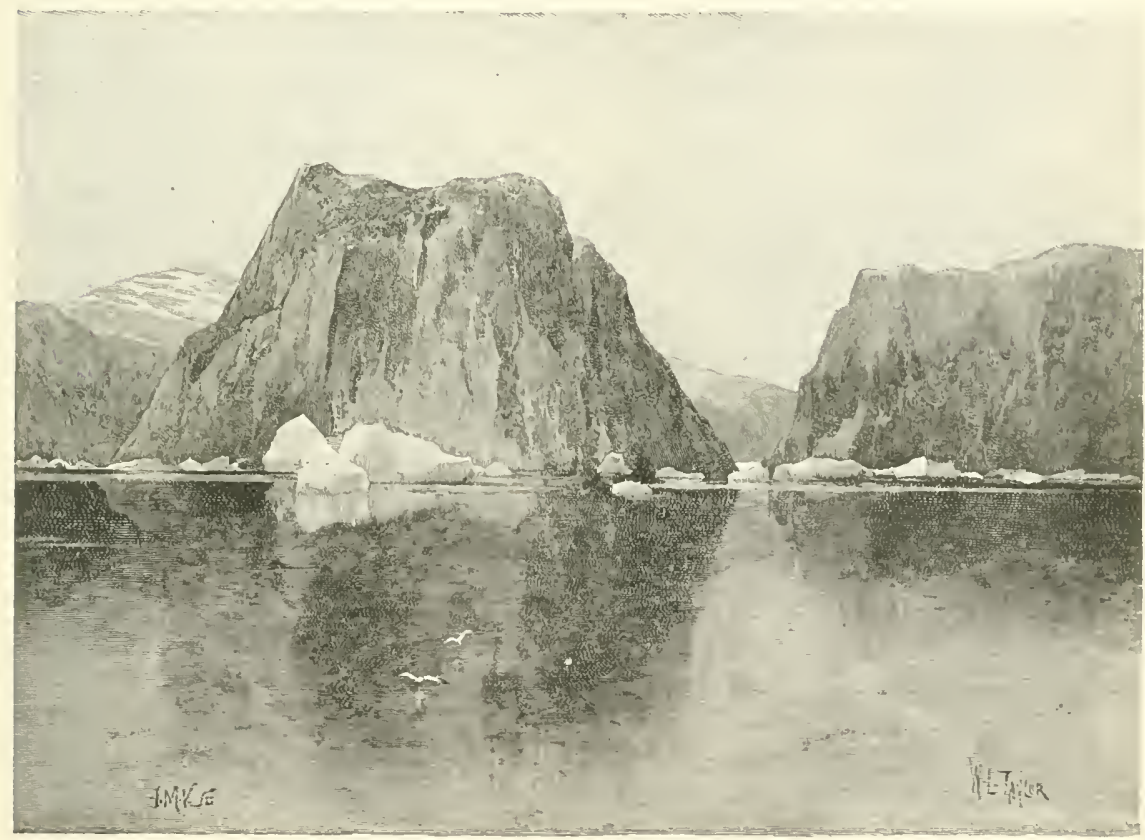

View at the Mouth of a Greenland Fiord

Showing the steep precipitous character of the coast. with a number of small bergs floating from the inlet.

Greenland, are retained near their place of origin by the action of the wind and the marine currents. It does rot seem likely that more than one or two hundred large icebergs make their way each year in the only practicable path that can take them beyond the Arctic Circle-that which is affordect by the current which sets out of Davis Strait, and down the Labractor shore, and then eastward into the Atlantic. Although we 
have as yet but little decided information concerning this ocean-stream, save that afforded by the movements of the bers and floe, we can readily see how it affects the journey of these wandering fragments from the vast Girenland glaciers. Though somewhat inconstant, this current is tolerably stealy, setting south through the wide channel which separates the shores of Greenland from those of the many islands which beset the northeast coast of the Imerican continent. By this southward-moving water the ice is propelled out into the open sea. The stream continues to the south, but widens and diminishes in the energy of its flow. It shortly comes in contact with the Gulf Stream, which it somewhat affects, and by which it is much affected. As we have already noticed, a part of the southward-setting current passes down along the shore of Labrador as a superficial stream of no sreat width or speecl. Another, and perhaps the larger part, flows bencath the Gulf Stream, and in time joins the great, slow-moving procession of Arctic waters which, following the bottom of the deeper sea, in the end attain the equatorial clistrict. For a considerable distance southeast of Greenland there are thus two distinct currents in the ocean waters-a lower, moving southwardly, and an upper, or superficial stratum, creeping toward the north. The thin floe-ice, floatins altogether within a hundred feet of the surface, is beaten back argainst the labrador shore by the surface stream; but the icebergs, because of their greater depth, are driven forward by the under-current in a southwardly direction. Owing to this peculiarity we sometimes may observe the bergs ploughing their way through vast fields of floe-ice as steadfastly as a steamship when it breaks its way in the new-formed ice of a harbor. This southward journey of the bergs is 
facilitated by the action of the prevailing winds, which, in this region, in the spring and summer, often blow with great energy from the northwest. A berg one hundred feet high and a mile long spreads a vast surface to these winds, and is slowly but effectually impelled by them in the manner of a sailing ship.

From the time the bery is launched into the sea it is constantly wasting; unlike the floe-ice, which receives important accessions in freezing weather, the berg, on account of its depth, which brings the greater part of the mass into water above the freezing-point, steadfastly diminishes in volume; the little ice-sheet which may form around the water-line does not affect the size of the mass, yet this process of melting goes on but slowly. In the first part of its journey it is always in water which is at about the freezing-point. Most persons are familiar with the fact that cakes of ice will float for a long time in very cold water, and can thus imagine that icebergs may journey a long way in the Arctic seas with but little loss in bulk. It is when they come in contact with the waters of the Gulf Stream that the dissolving process begins to go on in a rapid manner. The under-running cold current, which moves southward toward the central parts of the Atlantic, seizing on the great surface of the bergs which extends downward-it may be to one or two thousand feet below the surface-urges these masses of ice against the relatively shallow and slow-running warmer tide. As they go to the south the energy of the impelling stream constantly diminishes, for the reason that the flow from the Arctic, no longer confined within the channel between Greenland and the mainland of North America, slackens, while with each stage of the movement of the bergs toward the equator the 
strength of the Gulf Stream flow becomes augmented. In this way it comes about, that in the latitude of the Newfoundland banks, or shoals, the floating masses attain a position where there is a balance between the effects of the diverse currents, and, as a result of this, the iceberos lie idly in the sea or drift about in the varying winds until they melt away.

The bergs from the North Atlantic nursery of ice, from the glaciers of southern and western Greenland, have their limit of migration set by this curious equation of the currents which prevail in these waters. If the southward-setting current were as strong in that region as it is on the west coast of North America, there is no reason why these vast and slow-moving ice-islands should not attain to near the tropics; as it is, they are rarely if ever found much south of the Newfoundland banks. There are reports that in certain rare instances considerable bergs have been seen nearly as far west as the mouth of the Bay of Fundy and as far south and east as the Azores, but these stories lack verification and may be only sailors' yarns; if true, it is probably to be explained by the fact that in a period of long-continued and strong northwesterly winds deep bergs, which on account of their depth projected high above the water, were urged far to the southward and eastward of their normal course. Allowing for such rare accidents, the fact remains that the icebergs of the North Atlantic have their southward and eastward extension determined with admirable accuracy, and in a way to show the observer how beautifully the physical conditions are adjusted in the waters of that tumultuous sea.

The fact that icebergs can maintain themselves so long when they are floating with their upper parts bathed in the 
warm water of the superficial portions of the sea, and the deeper portions of their masses in a fluid which is a little above the point where ice melts, is due to certain circumstances which we shall have now to note with some care. The icebergs, as they slowly melt, chill the water about them to very near the freezing-point. This very cold state extends, in the case of large masses, to the distance of some miles from the face of the ice-cliffs. Next the bery the temperature is always but a shade above that of a vessel in which there is just enough water to float fragments of ice. Only a very small part of this cooled portion of the sea is derived from the melting berg; in the main it consists of that portion of the ocean which has been deprived of its heat by the contact with the glacial mass. Ilere we must consider the fact that the process of melting ice calls for a great deal of heat. If we take a cubic foot of the frozen water and put it over a regulated fire, as, for instance, that of gas-flame, we observe that it requires a much longer time to melt the mass than it would to bring an equal amount of icecold water to near the boiling-point. If we conduct the experiment in a more careful way, we may easily determine that, starting with a block of ice at a temperature just a fraction of a degree below the freezing-point, it takes more units of heat to bring it to a point where it becomes molten than is necessary to raise its temperature after it is melted to $74^{\circ} \mathrm{F}$. This heat, which the water hides away in the process of melting, is so great that it much affects not only the history of icebergs, but all the phenomena of the seasons in countries where a thick envelope of snow gathers during the winter season. It is this peculiar absorption of heat which makes it so difficult for the warm sun of spring to clear away the 
frostwork of winter and to fit the earth for the uses of vegetation. In the case of the icebergs the process of their melting requires that some cubic miles of the relatively warm ocean waters, having a temperature of, say, $50^{\circ} \mathrm{F}$, shall come in contact with the ice before an ordinary berg will be dissolved. Is long as the icebergs are rapidly pushed forward by the action of the undercurrent which urges them through the superficial layer of warm water, the portions of their masses which are exposed to the northward-setting stream rapidly melt, because they are by their motion ever brought into contact with the fresh fields of warm water, the cold portion of the ocean which they have chilled being left behind. But, as we have already noticed, the rate of this motion steadfastly decreases until they finally cease to travel over the surface, and meet only such water as the winds or the gentle northward-setting current sends against them. In a certain measure they provide by their own action for a slight current movement which promotes their melting. The water next their sides, being chilled by contact with the ice, becomes a little heavier than that of the surrounding sea, and so tends to sink into the depths, its place being taken by the warmer fluid which flows in over the surface. If water became continuously heavier as it cooled, all the way down to the freezing-point. this action would be much more effective than it is; but among the many extraordinary features of this substance we have to note that it is the elensest at about $39^{\circ} \mathrm{F}$, expanding a little if the heat is decreased below that temperature. Conserfuently this circulatory movement just described is not strong.

The protection of the bergs from melting is also promoted by the fleet-like manner in which they occupy large 
areas of the sea. They are generally found in troops, which may number scores, or even hundreds, of separate masses; the result is that vast areas of the ocean have their superficial waters so cooled down by the southernmost individual bergs, that the greater part of the group have little chance to come in contact with warm water; it is only slowly, as the advanced bergs are melted, that the more northern masses are exposed to a temperature high enough to affect them in any considerable measure. In much the same way the aggregation of the icebergs hinders the air from affecting them by its warmth; the atmosphere is chilled by the cold sea and the ice with which it comes in contact, and the result is that thick fogs are formed, which send off the rays of the sun and convert the regions about the beros into a natural ice-house well fitted to preserve them from the effects of the more southern realm into which they have journeyed. In fact, a fleet of icebergs takes its native climate with it as it goes; it is enveloped by conditions of its own making, as perfectly as if they were designed for the end which they attain.

The effect of the close order, which is such a common feature of the berg Aeet, is so important in their history that we must consider the way in which it is brought about. As is easily seen, the cause is found in the landlocked nature of the waters whence they are derived. In the winter the region about the $\mathrm{W}^{\top}$ est Greenland glaciers is occupied by a sheet of floe-ice strong enough to retain the icebergs against their native shores. Only for a brief period in summer, in all perhaps, on the average, less than four months, is the water open enough to permit their escape into the wicle part of the Atlantic Ocean. When the summer unlocks these Arctic gates, the vast assemblage of ice-Hoes and the im- 
prisoned squadrons of bergs from the several glaciers which have accumulated in the sea cluring the enduring frost, pour forth into the more southern part of the ocean. Then they become separated - the bergs impelled by the deeper current set forth upon their long cruise toward the mid-Atlantic, while the floes follow the surface stream adown the coast of Labraclor; the former to wander, it may be, for years; the latter to vanish in the heat of a single summer.

In the process of destruction which a berg goes through, its decay is aided by the frequent overturns to which it is subjected. All the ice of the glacial streams, unlike that made in the ordinary way, is moulded into shape under the great strains to which it is subjected in its journey over the surface of the earth. These strains are not all productive of movement, lut remain as tensions, much like those which we find in unannealed glass, giving the mass a tendency to fly into pieces. Moreover, glacier ice is peculiar in that it is always penetrated by numerous rifts or imperfectly closed fissures, which accelerate its breaking whenever it is violently disturbed. Owing to the more or less irregular melting which goes on upon the outside of a berg, its centre of gravity gradually changes, so that from time to time it rolls over in the sea. Such accidents are not infrequently observed by Arctic explorers and whalers who haunt the waters where these icefields most abound. As may be imagined, when one of these vast masses somersaults, every part of it is subjected to violent stresses which would rack much more solid structures, and also that, when they strand in some shallower part of the sea a like trial of their strength occurs. In fact, when cither of these accidents happens, the berg often flies into pieces almost as does a Prince Rupert drop of quickly cooled glass when it 


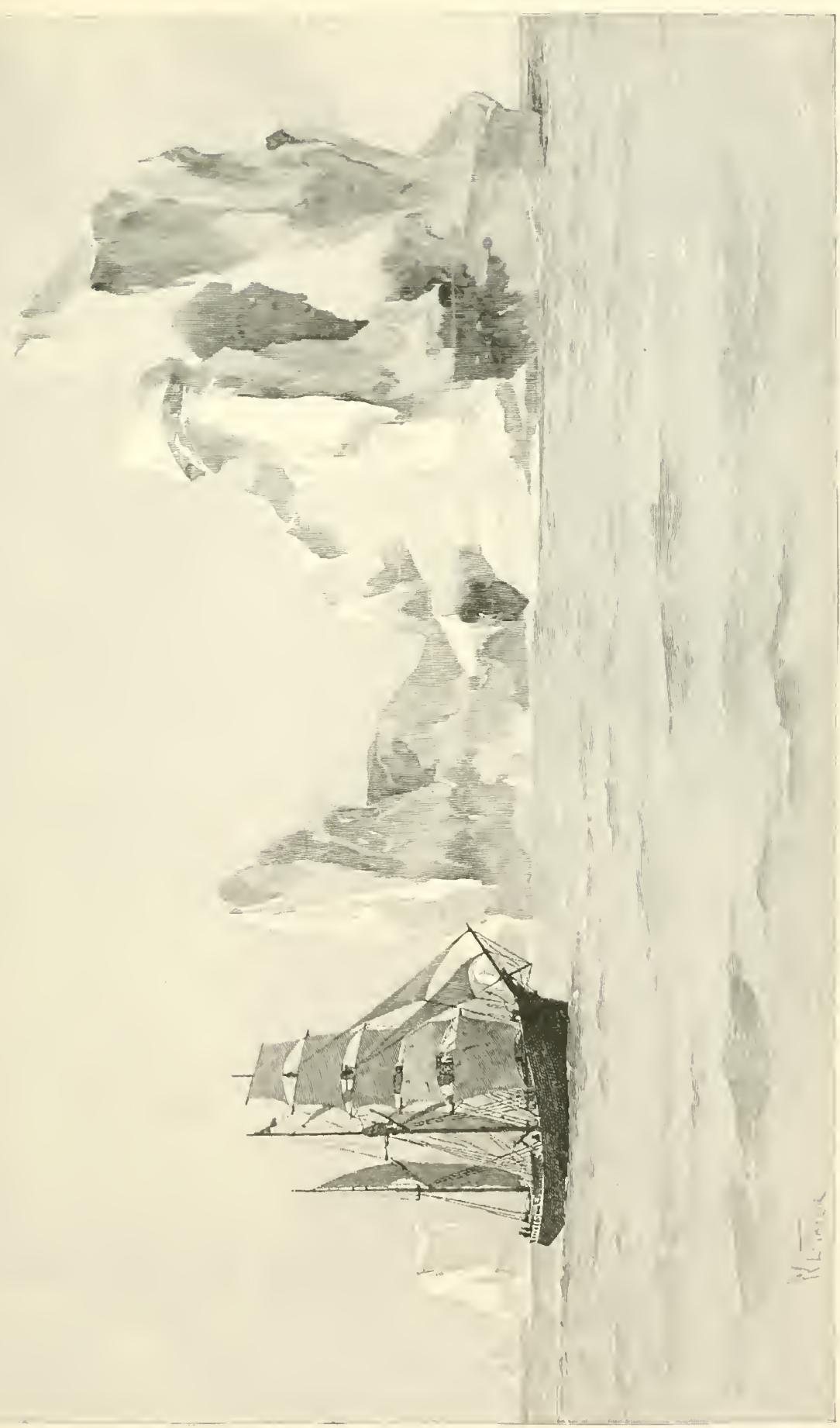



is treated with any violence. Even when sailing in a quiet sea the innate tensions of the ice, increased it may be by the changes of temperature to which it has been subjected since it parted from the parent glacier, now and then cause large fragments to fly from the steep cliffs, to float as satellites of the mass until they melt away.

The processes of decay acting on the summit of the icebergs reveal in the melting forms the existence of incipicnt rifts in their masses. Unlike the surface of ordinary ice-sheets, which commonly melt down somewhat evenly, the berg top is macie up of irregular pinnacles and chasms, which in the later stage of its existence may take on forms of the utmost variety. The picturesqueness of these floating islands of the north is in large measure due to the exceedingly varied form; of their shy lines. The architects of our day, who recognize the striking effects which may be produced in edifices by means of pedi. ments and pinnacles, might win suggestions from a study of these fantastic structures. These indentations of the icebery top are produced by the same abundant planes of weakness which cause the mass so readily to rend asunder whenever subjected to strains such as may arise from the causes we have considered. The warmth and rain penetrating into these crevices eat the ice away while the less weakened parts remain intact. In the case of many berss, even when they have been long afloat, the top is not much indented, for the reason that the frequent changes of position have not given the ice time to be affected by exposure to the air.

In the southern hemisphere, icebergs are limited to the western Atlantic and eastern Pacific, and to the waters of very high latitudes within the Antarctic Circle. They are almost unknown in the North Pacific, for the reason that the only 
glaciers which attain the sea in that region, those of the Alaskan shore, are of relatively small size and only send atloat small masses of ice, and these being imprisoned in deep bays do not often attain the open sea. In the Antarctic regrion the little-known islands about the South Pole are the nursery of more numerous berss than are formed within the Aretic Circle. The currents setting from these southern circumpolar lands toward the equator are much less energetic than those which bear the Greenland floods to the open sea, consequently the parts of these waters frequented by ships are not so affected by the ice invasions as are the waters lying between North America and Europe. The only point where the south polar berss come upon a travelled ship-route is on the western side of Cape Horn. In this field these wanderers occasionally penetrate a portion of the way of ressels which have rouncled the South American cape, but they are on the whole much less numerous and less dangerous to navigation than those of the North Atlantic. It is a peculiarity of these southern ice masses, that they are much larger than those observed in the North Atlantic field. This is probably due to the greater extent of the glaciers in the region about the South Pole, and to the correlative fact that the process of melting goes on more slowly in that region than in the Arctic district.

Besides the greater size of the icebergs of the far south as compared with those from the Arctic regions, it may be noted that the tops of the floating masses are often described as being table-like, lacking the pinnacled look which is so generally exhibited by those which come from the Greenland glaciers. The reason for this is probably to be found in the very great extension of the Antarctic ice-cap. About the 
North Pole the ice streams pass to the sea through valley's in which the material becomes much rifted. In the Antarctic realm the accumulations of frozen water extend beyond the shores, and probably move over the bottom for a great distance before they attain a depth in which they can float. Thus the bergs of this region are to a great extent made outside of the valleys, and thus have a homogeneous structure which causes them to wear away more uniformly than those which are made in Greenland.

IVe turn now to consider those parts of the general effects of floating ice which may be supposed to have an interest for the reader. First among these we must reckon the influence they exercise on the climatal conditions of the countries bordering on their paths. In the case of the floes and icebergs which are borne southward by the Labrador currents, the effect must be considerable; they perceptibly cool the sea over a large area, depriving a considerable part of its waters of the warmth which their current would otherwise carry to Northern Europe. If we could confine these wanderers from the icy realm within the regions where they are formed, the effect on the temperature of Northern Europe would be noteworthy and even of economic importance. Their general influence is to disseminate Arctic conditions over a wide area of the more southern regions, where the climate tends through the action of the ocean movements to partake of the tropical warmith. The climate of the northeastern part of North America would probably be distinctly warmer but for the chilling of the neighboring sea which the abundant ice induces. So, too, with the southern part of South America; the climate which now renclers the country in good part unfit for agriculture would be much more tolerable but for the 
influence of the vast amount of ice from the Antarctic Sea which floats near to its shores. Though not of great importance in terrestrial conditions, icebergs must be reckoned as a factor with which the meteorolegists of the future will have to deal. In forecasting the weather conditions not only of the seas where they occur, but also of the neighboring lands. it will be necessary to take account of the migrations of these wanderers from the polar region, and to estimate their effects upon the heat and moisture of those districts.

To the student of the geological processes which are now going on upon the earth, iccberss, and icc-floes as well, will afford most interesting subjects of incuiry. Not only do they affect the temperatures of the sea and land, and thus indirectly influence the conditions of the life they bear, but they exert certain curious direct effects upon the distribution of organic species and in the carriage of sediments. We will first note the action of these floating ice-fields in cariying animals from once region to another. It is the habit of the animals of high latitudes, particularly the polar bears, to seek the margin of the sea for the food they may obtain from its waters. The bears indeed win in winter their entire subsistence from this source of supply; even in summer they obtain little else than what the ocean affords them. Prowling along the shore and swimming far in its waters, with occasional rests on the floating ice-islands, it frequently happens that they are borne away to sea on these rafts. In most cases these creatures starve to death or are drowned when their supports melt away; but it sometimes happens that the wandering ice conveys them to some other land. Grounding in the shallow water next the shore, the animals, if not too much exhausted, may win the shore and proceed to multiply in their new-found home. 
From time to time the polar bear is thus conveyed from Greenland to Iceland, on which island it is not indigenous. The people of this Arctic realm are compelled to exterminate the invaders lest they should destroy their cattle and ravage their fields.

As the icebergs are derived from glaciers, they commonly

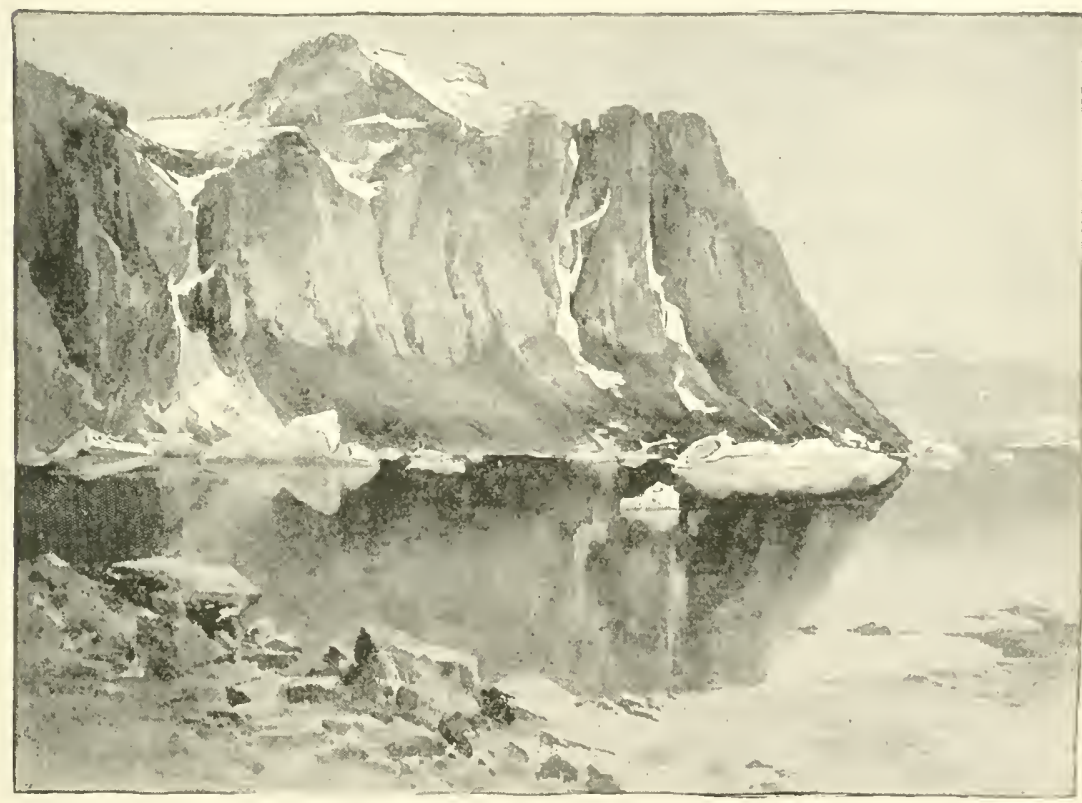

View of a Part of th $\geqslant$ Coast of Greenland

Showing small glaciers and floating icebergs. In the foreground are masses of rock dropped irom floating ice.

carry a great deal of rocky matter torn from the surface over which they have found their way. The bottom portion of any thick glacier is commonly filled, sometimes to the depth of a hundred feet or more, with this fractured stone, varying in size from grains of mud or sand to blocks the size of a small house. When the icebergs float away from the land they bear the mass of debris with them on their journey, it may be for a 
sreat distance from their birthplace. If the berg remains for a long time in the position in which it entered the sea, a relatively slight amount of melting will release the stones and earthy waste, which will then fall, bit by bit, into the sea-floors in the paths of the wandering ice; but as it often happens that the berg is turned upsicle down before it has attained any great distance from its point of origin, in this position the waste from the land will remain afloat until the ice again capsizes or melts away, when it will be tumbled into a heap on the ocean bottom. In this way a very large amount of the land waste torn from the beel rocks by the action of the grlaciers is distributed far and wide over the surface, where new strata are constantly accumulating. The number of icebergs delivered to the open sea in the summer season, of either Pole, must amount to many thousands. It will be probably safe to estimate the aggregate area of this floating glacial material as not less than five hundred square miles in surface. It will also be reasonable to reckon that the dibris from the circumpolar landis contained in these bers is sufficient to form a layer not less than one foot in thickness over all this field of ice. On this basis we find that in one thousand years the sea-floor, over an area of one million square miles, might receive a contribution of debris having a mean depth of six inches. Although these reckonings are to be taken only as probable, or perhaps possible, estimates, it is evident from them that the land areas about the Poles are rapidly wearing away, and that their waste is being deposited with extreme rapidity upon the floors of the oceans in hish latitudes.

While the massive icebergs are carrying on this singular work of depositing the waste of the circumpolar regions on the wide fields of the oceans, the ice-floes are doing a similar, 
and perhaps equally important, work in conveying the detritus from the shallow waters next the shore out to sea and along the coast-lines in considerable though less extendeci journeys. In the winter season, when the floe-ice forms or thickens in the shore-packs which beset the lands in high latitudes, the stones and other movable detritus of the coast-line become frozen into the sheets, and when they float off in the spring season are rafted for some distance, and finally, but more speedily than in the case of the materials conveyed by bergs. are dropped upon the bottom. The carriage is for a less distance, because the floe-ice, being thin, survives for a less time in the sea-water. The immediate effect of this action is to rob the shore-line of the dicbris which the waves have phucked from the cliffs, and thus to hasten the wasting of the shores; it also contributes a large amount of detritus to the ocean depths. Although this action is of most importance within the Arctic Circle, its effects are felt all along the shores where ice forms to the thickness of a foot or more, and after severe frosts floats away seaward. Its influence has long been remarked in the waters of the Baltic Sea. One of the English men-of-war which was sunk during the attack on the Danish fleet in $\mathrm{I}$ So\%, was visited by divers seven years after that battle; its deck was found covered with blocks of stone which had drifted there in ice-floes. It is said that all sunken ships in that part of the sea quickly become overlacten by a thick coating of rock débris.

In the occasional severe winters which occur along the New England coast as far south as Rhode Island, this Hoe-ice makes to a thickness of three feet. Under the influence of the strong tides and winds these ice-fields are often urged against the shore, upon which they break into fragments, which are 
crowded by the great pressure from above and below until they form extensive ramparts which are frozen solidly together. When these masses float away they often carry with them bowlders weighing one to two tons, and drop them at a distance from the land. In their collision with the shore these fields of rock-covered ice exercise a very great disruptive force. At many points, even in Southern New England, it is difficult to build piers, even of frrm masonry, strong enough to withstand their assaults. The fact that these artificial constructions fail to withstand the action of this floating ice, shows how vigorous is the attack which it makes on the shore. All persons who are familiar with the coast of New England, especially those who have an intimate acquaintance with the districts of any particular portion of it, must have remarked the often conspicuous changes which a rery frigid winter brings about in the appearance of the bowldery shores. ITe have then only to conceive that in the ages these actions are to be multiplied by the million-fold, in order to make it clear that this agent is capable of accomplishing a great cleal of geologic work. In general this work is most effectively done in the embayments of the shore, for on the headlands the waves prevent the ice from forming, or keep it broken into small blocks, so that it cannot seize upon the large stones; in this way the floe-ice serves to wear away the shores of recntrants more than those of the headlands. Sand-beaches are but little affected by the ice which may form upon them, for the reason that the continual movement of water from the land side prevents their materials from freezing, so that they do not become entangled in the floe.

When geologists first sought to interpret the ice marks so common on the surface of the lands in ingh latitudes, they 
were almost necessarily led to the supposition that those scorings of the rocks and carriage of detrital materials had been brought about by berg action. Explorers who had cruised in high latitudes had noted that the floating ice contained quantities of glacial waste, and also that the masses were often driven by the wind against the bottoms of the shallow seas. It was, moreover, well known that in the process of geographical change regions which have recently been sea bottom have been converted into dry land. Thus a natural explanation of the facts appeared to be attained. Further inquiry has shown, however, that the greater part of the ice work in glaciated districts is not due to iceberg action, but to the movement of vast united masses of ice such as now covers the central portion of Greenland. Here and there. however, along the shores, and even at heights of some hundred feet above the sea level, we find indications that during the waning stages of the ice epoch the land was lower than at present, that it was cruised over by beros which now and then grounded and often dropped the waste embedded in their masses, and released during the process of melting, upon the surface of the earth. Thus the original theory adduced to explain drift phenomena has, by the evidence, been pushed into a very subordinate position.

In a number of ancient geological formations we find evidence through the presence of stray blocks or heaps of detrital matter embedded in finer materials, serving to show that the seas in such periods were cruised over by iceberys. These indices are of great value for the reason that the land record made by a glacial period is quickly destroyed by decay, so that the work clone by icebergs, the record of which is quickly buried in the submarine strata, may be all that is 
left to show that glacial work had been done in the ancient time.

As we have now considered the more important general features which floating ice presents to the greologist's eye; it will not be uninteresting to devote a part of this paper to the questions concerning those masses which have a more human

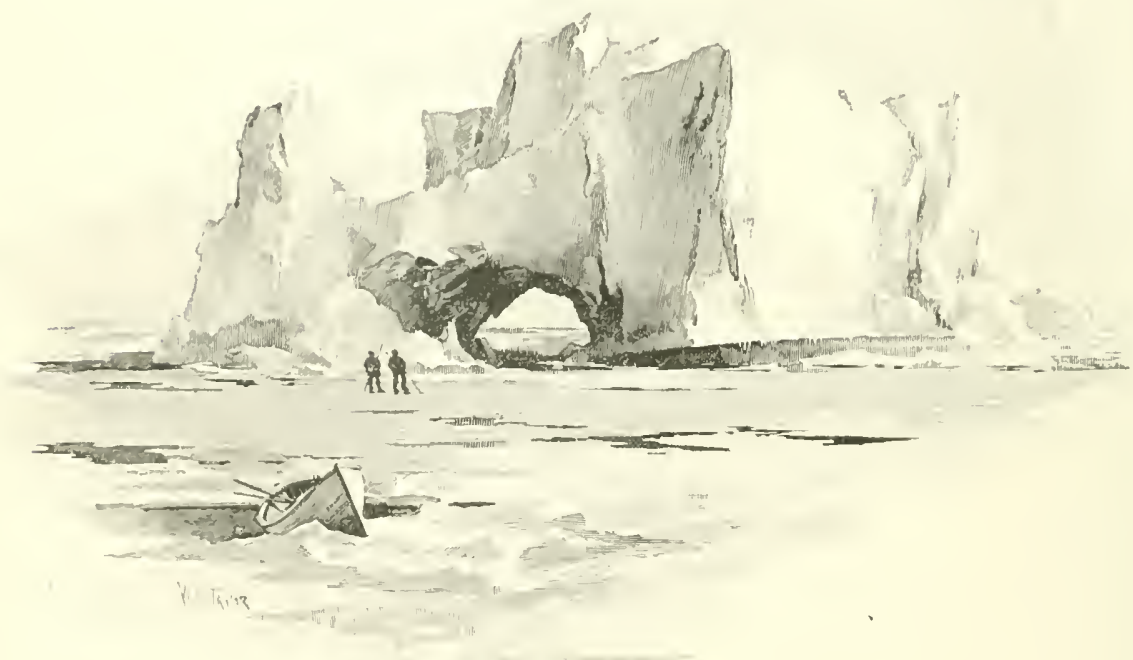

Vew sh wing La'ge Berg w th tce Arch

The overhanging ledge to the right of the arch shows a former sea-level on the face of the berg, and indicates that the mass has recently slightly changed its position in the water.

interest, viz., their scenographic quality, and the dangers which they bring to navigators.

In taking account of the place occupied by any natural phenomena, it is well to consider the effect which they produce on the asthetic sensibilities of man. From this point of view we must give a high place to the greater ice-masses of the sea, the bergs which come down from the circumpolar saciers. There is an architectural splendor in many of the 
aspects of frozen water, which is found in no other natural forms. Majestic as is the tumult of Niagara, the scene inexpressibly gains in sublimity when winter has framed it in an encasement of ice. The Alps and the Himalayas have a dignity which is in but small part due to the hardy forms of their rocky slopes, but is lent them by the snows of their uplands and the glaciers of the valleys. Even the snow-sheets of an ordinary house-roof, and the fringre of icicles pendent from its eaves, may make the most commonplace building a curiously impressive and pleasing object.

There is, perhaps, no condition of frozen water in which this element of the picturesque is more pronounced than where it is exhibited in a fleet of icebergs within the regions where they have not yet been worn out by lony journeys. Those who see them only in the usually traversed route between the American ports and Europe behold but the scanty relics of the vast structures which started from the Arctic Ocean months before. The charm of these floating islands consists, in part, in singularity and variety of forms, and in the beauty of their coloration: but in larger part the effect is due to the weird loneliness and lifelessness of their crags and steeps. Save for the splashing of the sea ayainst their steep sides, or the hoarser crash of the masses which now and then tumble from the heights to the lower levels of the floating islands or into the sea, we may journey for hours through the berg tleet in perfect stillness. When the floating masses are near together, as they often are in the high north, where sometimes hundreds may be seen in a day, they shut out the wares and make an almost cavernous stillness in the space of water between them. The impression made on the mind by a strong sea breaking against a rock-bound shore, and that of 
a volcano in energetic eruption, are more startling; but it is cloubtful if any of the aspects of nature, save the ever-familiar depths of the heavens, is so awe-inspiring as that exhibited by a great flect of beross as they come forth from the icy mountains of Greenland for their long southern voyage.

One of the most notable of the manifold modern developments of interest in the external world is that which leads people to make long journeys to behold the more inspiring scenes of nature. It seems likely that in a few decades this relish for the flavor of scenery will, among cultivated people, become as well dereloped as that of the Romans of the second century for the luxuries of the table. When this stage of our social development is attained, we may expect that the fields of the icebergs will be as much visited by the seekers after the nobler aspects of nature as are the ice-streams of the Alps; certainly this world has no more impressive spectacles than those afforded by the high northern seas when their vast annual flect of bergs set forth on their journey into the broad Atlantic.

Against the good which is given us in the grandeur and beauty of the icebergs, we must set the grave and inevitable danger which they bring to the seafarer who has to traverse the waters where they abound. These dangers have always been great, but are more serious in this age of swift steamships than of old. Against the common perils of the sea the skill of shipmaker and shipmaster, when at their best, can effectively guard. The ocean is so well charted that there is no island in the usual paths of commerce, hardly indeed a rock which need be approached, the position of which is not well known. The art and science of navigation is so well explored and taught, that with the aid of his chronometers 
and sextants the navigator can often without risk almost graze these obstructions with his keel. There is no longer much to be apprehended from storms; our abler commercial ships at least can make light of the winds which might have overwhelmed an ancient armada. Among the first-class oceangoing ressels of this day, only the armor-laden men-of-war, which are indeed rather floating fortresses than ships, have any serious reason to apprehend the results of a tropical hurricane in the open sea. But all these conquests of the modern sailor depend upon the application of skill to wellascertained facts: the difficulty with icebergs is that their position in the sea, where they lie until they melt, is essentially anomalous.

The only information which the navigator can have as to the existence of these obstacles in his path is derived in part from the reports of the shipmasters who have recently traversed the path which he is following, and in part from the conditions of the air and water about his vessel. The reports of his predecessors may lead him to believe that in about a certain field of the sea ice abounds. If he be a wary personand fortunately for the ocean travellers these men are caretaking beyond the understanding of most landsmen-he will watch the temperature of the water and attend to the conditions of the air when he comes into the suspected district. When his ship enters into a chill, foggy atmosphere, he will suspect the neighborhood of ice; if the thermometer shows that the water has suddenly lowered to near the freezingpoint, he will know that he is very near the bergs. But good as these indications are, they are not unerring. Small bergs, though trifling remnants of greater masses, though they may be less in bulk than the vessel itself, are sufficient to bring 
about the destruction of the strongest ship that floats, if the vessel encounters them when going at a speed of fifteen or twenty knots an hour. These berglets often float to a great clistance from the main fields of ice, and being small, do not affect the temperature of the water or of the air. Again, it sometimes happens that a strong wind will drive the air and water before it, so that there is no fog about the bergs and no very cold water on the sicle from which the bergs are approached. These exceptional conditions make the path of a ship, which in the night-time traverses an iceberg-laden portion of the sea, the seat of grave perils.

A collision with an icebers has certain elements of hopelessness which belong to no other calamities of the deep. Colliding with another vessel, the blow is not likely to be so severe as to clamarge more than one of the compartments of a ship, the others may keep her afloat. An iceberg, owing to its unyelding and massive nature, gives a much harder blow. Moreover, as the experience of the steamer Arizona showed, the fall of masses of ice from the cliffs of the berg upon the bow of the ship, is likely to add to the damage done to hel forward parts. When ruming against another ship, or against the land, there is always some hope of rescue or of refuge for the shipwecked people, either on the shore or the deck of the other vessel; but no more hopeless condition can be imagined than that of people who might seek a foothold on the inhospitable islands. The steep, generally' overhanging, cliffs, usuaily deny access to their summits, and even if by chance the shipwrecked people attain the summit of the ice, they would have little chance of rescue, for no craft willingly comes near to those dangerous objects.

It has been suggested that the men-of-war of the great 
navies should be employed in the destruction of the icebergs of the North Atlantic. According to this plan the bergs are to be bombarded with great shells, which, penetrating deep into the ice and exploding there, will shatter them to pieces. There is no doubt that this would be a far more profitable expenditure of ammunition than the uses for which it is designed; for any target is better than the dear-bought frame of man or the products of his skill of hand and mind ; but it is more than doubtful if the end coukl be attained in this way. In the first place, to accomplish the desired result, it would be necessary for men-of-war to watch the exit of Baffin's Bay in the spring-time, and break up the bergs into relatively small bits, so that they would no longer float with their bases in the deep southward-setting current, but would drift with the floe-ice. To do this, with several hundred great masses, would require an enormous expenditure of money. Including the wear and tear of guns, the shells from the great modern ordnance cannot be fired at a less cost than five hundred dollars for each shell, and it would probably require many hundred rounds of ammunition to break up a single berg. It would not at all serve the purpose to rend the ice to pieces in the mid-Atlantic district, for there the fragments would float about and multiply the dangers of navigation; such work, if done, would make that region nearly impassable for a portion of the year, though from the readier melting of the ice the trouble would not endure so long. On the whole, this interesting project does not seem practicable.

The only way to avoid the perils due to this berg field of the Atlantic is for ships to take a course which will lead them to the south of the tclerably well-marked field into 
which the iccbergs journey. The detour which it is necessary to make, even in the years when the ice-fleets are most numerous and journey the farthest south, would be but slight; it would not add more than a day to the duration of the voyage. The tlecter scouting ships of the war marine might well be employed in reconnoitring the position of these enemies, so that their place would be well known to the merchantman. With these relatively slight precautions there is no reason why, in the century to come, when the Atlantic shipping is tenfolded in amount, this sea should not be traversed without any danger from this source. 


\section{HARBORS AND CIVILIZATION}

First Condition of Ships.-Origin of Maritime Habit ; Relation of Habit to Form of Shore; Effect on National Progress.-Condition of North America as regards Ilarbors.-Requirements of a Good Port.-Classification of Ilarbors.-Delta 1larbors. - Valley Harbors: How Dependent on Changes of Level.-Fjord Harbors : 'The Conclitions of their Formation; Value as Ports.-Mountain Range IHarbors.-Morainal Ifarbors.

OxE of the most important steps which lead from the primitive savage state toward the ways of culture and civilization is taken when men contrive instruments of navigation. Almost all the peoples of the earth have accomplished this first stagre of advance. Only a few inferior races are without devices in the way of boats. Although this art of navigation is itself a powerful instrument of culture, inasmuch as it teaches men to contrive and use tools, to face danger and to associate their action in a very educative way, it was only slowly and rarely that they attained sufficient skill in the construction and management of boats to venture upon broad waters. Ships of considerable size, fit to undertake long voyages, appear to have been separately invented at sereral different points in the Old Morld-by the Scandinarians, by their kindred Aryans of the Mediterranean, by the Chinese. and perhaps, separately, by the people of the Malay archipelago and of Hindostan. The Phonicians and other Semitic people early acquired the art of constructing large boats, but whether by their own invention or by copying those of other people is uncertain. 
For a long time after sea-going ships were invented, they were of small size; they all appear to have been without keels and to have been propelled by oars, with only an occasional use of sails. Craft of this sort were to a certain extent independent of harbors, or at least needed them only as landingplaces, for it was a common custom to drags them on their flat bottoms up the surface of any smooth beach. In other words, they preserved the type of rowboats such as are normally used on inland waters. It was not until about two thousand years ago, when the use of ships for war purposes on the Mediterranean led to a great increase of their size, that vessels lost their amphibious character, became permanent denizens of the sea, and had to be sheltered in good harbors when they lay near land. After the invention of the keel, merchant ships gradually abandoned the use of oars for propulsion; they were increased in size, and so in time all commercial craft came to require the protection of harbors in receiving or discharging cargoes. During the last century this enlargement of ressels has gone formard with exceeding rapidity, so that at the present time the average tonnage of sca-going ships is at least fivefold as great as it was a hundred years ago.

The maritime spirit of the different peoples that resort to the sea was developed and determined in the ages when ressels had not passed beyond the stage of boats of small size. Their first lessons in scamanship seem to have been acquired in tolerably sheltered waters where bays or islands favored tentative experiments in navigation. Wherever any of the shores of the Old Wrorld abound in inlets or are beset with islands, if the country was inhabited at an early day by people capable of advance in the ways of life, we al- 
most invariably find that the maritime spirit was developed in a measure quite up to the progress in other arts. On the other hand, wherever the shore was not deeply embayed or fringed with islands the folk seem never to have acpuired the mariner's craft, however far they have adranced in other constructive arts. Thus the Egyptians, though marvellous builders on the land, never became a seafaring people; their marine commerce appears to have been managed by other folk, bred in districts more favorable to the development of seamen. The Peruvians possessed architectural skill, but they were never tempted by the conditions of their coast line to venture far upon the sea. We thus perceive that natural harbors, or rather the conditions of a shore line affording, as it were, a gradual passage from the conditions of the land to those of the wide ocean, faror the development of sailors.

The two most remarkable cradles of navigators are found in the peninsulated and island-bordered shores of Europe and in a somewhat similarly conditioned region in Southeastern Asia. Both of these districts, where land and sea are much entangled, have developed singularly maritime people. The Malayan region, verging eastward into the vast archipelagic sea of the tropical Pacific, has bred a folk exceedingly skilful in seafaring. Although the range of their arts as determined by their share of natural ability has proved limited. they are perhaps for their social estate the boldest voyagers in the world. Their ventures, however, have been made in waters tolerably exempt from severe storms, so that their relatively frail vessels were insured from the graver perils of the deep. The seafaring arts of Europe were developed under very different conditions from those of the Malayan and Pacific islands. All the shores of Europe are storm-swept. Even 
in the Mediterranean the climate is tempestuous, and ships have to be well built and equipped to meet the heary waves, and sailors must be masters of their art. Noreover, in that continent the Aryan people have their principal seat of empire, and this race, by stern proof through centuries of trial, has been shown to contain the preëminently seafaring men of the world. The Semitic and Chinese races have exhibited a comparable skill in various other arts, but the Aryans have ploughed the seas with a courage and success unapproached by any other variety of men.

The subdivisions of European people show a variation in the measure of their maritime success grenerally proportionate to the degree in which the physical conditions of the countries they occupy favor training in the seafaring art. The great peninsulas and islands of the northern part of the continent, Norway and Sweden, Denmark, and the British Isles, have developed the preëminently maritime states and peoples. The best of these nurseries of seamen was of old in the Scandinavian peninsula, where our ancestors formed the cruising habit, where they developed the courage and address required for journeys over wide and unknown seas. 'The folk of these peninsulas were nurtured in a country which could not have been better contrived for the maritime development of a people. The shore is so intersected with deep reëntrants, penetrating far into the land, that the navigating habit was in a way imposed upon the people. No vigorous race could develop in such a country without learning how to manage a boat and without being invited to extend their voyages from the simplest essays in narrow land-locked channels to everenlarging ventures which finally led them to face the wide ocean. The Northmen took with them their seafaring habit 
when by successive steps they conquered Britain, and it is in the main their motive, transmitted by the inheritance of blood and habit, which has made our own people for two centuries successful in the exploits of war and peace upon the seas. More than five centurics before the Mediterrancan people lared to traverse the safe waters of the trade-wind belt which separates Europe from America, the hardy Northmen found their way, in their frailer craft, across the storm-swept waters of the North Atlantic to the American shores. Greenland at least was the seat of permanent settlement and the object of innumerable voyages centuries before the Southern Europeans dared venture far beyond the Pillars of Hercules.

The vast importance of the seafaring habit to the history' of a people may be judged by its effect upon the fate of the English folk. Owing to their skill in seamanship and their courage in facing the dangers of the deep they have been able to establish their possessions in every part of the world which may have particularly tempted them to colonizing rentures. By way of the sea they have been led to become an aimost world-wide people. Of the three New-Morld continentsNorth America. South America, and Australia-they possess Australia altogether, and almost all of North America: only the southern of the twin continents has escaped their grasp. Nine-tenths of the valuable islands beyond the limits of Europe belong to the English-speaking people, or to their kindred. the Dutch; in a word, through their maritime power those North Europeans bid fair in time to dominate every part of the world which is fit for their occupation. These considerations make it plain that the way to national power is orer the waves, and that this way is the natural path of our race. It is on this account that all those natural features which we are 
about to discuss may fairly claim the attention of our people.

Although by means of modewn engineering devices it has proved possible to construct, thougin at very great cost, tolerably good shelters for ships even on harborless coasts where the physical conditions are not favorable for such undertakings, there seems no reason to expect that any advance in the engineer's art will ever exempt a country from the disadvantages which the absence of good natural ports entails. While defective harbors may be improved by engincering devices at reasonable cost, the creation of havens is impracticable except under peculiar conditions, such as occur at either extremity of the Sucz Canal. Ne may therefore assume that hereafter, as heretofore, the well-harbored lands of the world will remain the seat of the dominant scafarers, and that the Northmen folk-the English. Scandinavian, Dutch and Germans-and their descendants in other parts of the workd, will remain masters of the sea and thereby retain and extend their power in the conduct of the world's affairs.

The measure in which power rests upon the keels of ships may be seen by contrasting the history of Great Britain and that of Switzerland. In all that relates to manly qualities or to intelligence in commercial affairs, the peoples of these two countries maly be regarded as equals. But the Swiss have been limited to their mountains; the power of the state has never been felt more than a few hundred miles from its borders, and its influence in the affairs of the world has been accomplished altogether by its fame and its emigrants. On the other hand, Great Britain, as before remarked, owing to the long training in seafaring which its people have received, has become the dominant power of the world. As will be 
made evident in the sequel of this essay, North America, and particularly the part of it held by the United States, is more advantageously placed in relation to marine navigation than any other equally extensive portion of the lands of the earth. Owing to the shape and position of this continent it faces the two great divisions of oceanic waters, the Atlantic and the Pacific, and nearly all parts of its area are readily accessible from the shore by rivers or relatively short railways. At no point on its coast line lo we find a stretch of shore of more than three hundred miles in length which is without a haven suitable for modern shipping or which cannot readily be made into a good harbor.

In addition to the advantages arising from the relation of this continent to the oceans, North America is singularly well placed for internal marine commerce. On its southeastern side lie the great inclosed basins of the Caribbean Sea and the Gulf of Mexico, which together form one field of tropical waters, exceeded in their extent and the richness of their shores only by the Mediterranean Sea and the Sea of Japan. This great American basin lies between and in a measure unites the continents of North and South America. ()wing to their essential unity these basins might fitly be termed the Columbian Sea in honor of the explorer who first penetrated to this part of the world. A straight line drawn in this basin from Galveston, Texas, to the western mouths of the river Orinoco, has a length of about twenty-eight hundred miles. The total area of its waters is about the same as that of the Mediterranean, and the economic resources of its shores are probably greater than those of the Old World's historic sea. Into this basin discharge the waters of two great navigable river systems, the Orinoco and the Mississippi. 'Thus there 
may here be united by water transportation the products of the temperate and tropical zones. Owing to the political and social conditions of this American Mediterranean, it has, as yet. played but a small part in the commerce of the world, but the possibilities of commercial development which it affords are very great.

The northern part of North America, both on its eastern and western faces, abounds in extensive embayed waters, which in their general character resemble those of Scandinaria and which are equally well fitted for the development of sailors. On the Atlantic side, to the north of Newfoundland, the rigorous climate is likely to debar the land from much use by civilized man. On the western shore, however, north to Bering Strait, the forests, mines, and fisheries are likely to make the bays and fiords the seat of a great maritime life. On the southern portion of the Pacific shore the Gulf of California, one of the longest embayments of the sea in the world, has an extensire coast line, and, though its shores are of an arid nature, it is likely to have an importance in the development of our semi-inland navigation.

In the central and northwestern part of the continent lies a great system of lakes, which together constitute the most extended series of fresh-water seas known in the world. Already the Laurentian portion of these waters, which we fitly term the Great Lakes, is the seat of a vast and continually augmenting commerce. With the development of the Canadian Dominion, the yet more northern and western basins which lie in the valleys of the Nelson and McKenzie rivers are likely to attain much commercial importance. It will thus be seen that North America, in all that relates to water transportation, both that which lies within the continent 
and that which is favored by ready access to the open sceas, is better placed than any other of the continental areas. It is therefore fit that our people should feel themselves interested in all questions which are connected with navigation.

From the time of the settlement of this country from England to the beginning of our ciril war, the English part of our population was intensely interested in seafaring. In the middle of the present century our commercial marine, including the coastwise traffic and that of great lakes and rivers, was the most extensive in the world. The disturbances of the civil war to a great extent broke up our foreign commerce. Since the reunion of the country the development of the region beyond the Mississippi and of the Cordilleras has absorbed the energies and occupied the capital of our people to such an extent that we have been little concerned with the trade beyond our own borders. Now that the important task of winning our internal empire to use is in good part accomplished, there is reason to believe that we shall enter upon the peaceful conquests of trade with remote lands in the manner of our ancestors, but with vastly greater resources for the development of that form of commerce. It is safe to say that, at the end of the next century, and perhaps near its very beginning, all that relates to the conditions of our coast line will appear to us much more important than at present. Therefore, we may presume that such studies as are here essayed concerning American marine ports will be timely and will at least in some considerable measure anticipate the interests and needs of our people.

The conditions necessary to fit any part of the shore to serve vessels as a shelter and landing place are in general as follows, viz.: 'The haven must be protected from the incur- 
sion of heary waves; it must be provided with a channel of sufficient depth leading from the anchorage to the open water; the place where the ships may lie needs to be so located that they may readily discharge and receive cargoes, and the landing must be convenient of access to the internal commercial routes of the district wherein it lies. When these conditions are satisfied the haven in question is likely to have a measurable importance, but many other conditions have to be met before it will be entirely fit for commerce. The sheltered waters of sufficient depth should afford good anchorage ground and be roomy enough safely to accommodate many ships. The way of access from the sea should be deep and direct; it should, moreover, not be the seat of very strong river or tidal currents, for the reason that such streams are likely to put vessels in jeopardy. The shore near the harbor should not be exposed to great masses of moving sand, for these drifting with the currents are likely to endanger the passage to the sea or by frequent changes to confuse navigators. The refuge should be cxempt from closure or serious embarrassment by ice. However good it may otherwise be, such obstruction, even if temporary, very much affects the value of a port.

IVe shall now proceed to consider the physical conditions which lead to the formation, preservation, and destruction of havens. In the treatment of the subject we shall naturally be lecl to a classification of these basins, based upon the circumstances of their origin. Ne shall also be led to group in due orcler the forms of energy which operate to preserve or destroy ports, and the measure in which these actions may be affected by the care of man.

The simplest condition which leads to the institution of 
a harbor are found where a large river enters the sea. Ordinarily the passage of the stream from the land to the deep takes place through a considerable accumulation of detritus which has been brought down by the stream and spread out in the form of a delta, such as exists at the mouth of almost all the great rivers of the world. These delta ports, as we may term them, were among the first to be used for marine commerce, and remain among the most important harbors in the world. Their commercial value is peculiarly great, for the reason that they are always connected with an extensive area of more or less navigable river waters which afford a natural way by which the materials of commerce may be conveyed to and from the interior parts of the country. Thus, in the case of the Mississippi system of waters, shores, having an aggregate extent of tens of thousands of miles, are accessible to the delta port at its mouth. The narigable waters of the Amazon are of yet greater extent. There are in the world at least a dozen of these delta ports which, from their commercial importance, are or in time will be ranked as havens of the first order.

Along with their advantages delta harbors exhibit certain grave defects. While the water in the channels which are well within the area of the delta is usually deep (and this for the reason that the motion of the stream keeps the passage clear), the entrance to the river channel is commonly made difficult by a widespread deposit of mud which stretches for some miles seaward beyond the mouth of the stream. The formation of this outlying fringe of mud flats is brought about in a manner which can be readily understood. When the river waters enter the sea they are no longer under the influence of the current of the stream which bore them on; 
the mud which they abundantly contain therefore settles upon the bottom of the sea. Its precipitation is favored by a mixture of the salt water with that which has come from the land, for, as is well known, the infusion of a certain amount of salt with water containing suspended mineral particles hastens the process by which the sediments separate and fall to the bottom. Is long as commercial ships were of small size, drawing no more than twelve or fiftecn feet of water, delta ports of this class were generally suitable for commerce; but with the increase in draft of our modern ships, these havens require engineering work to make them fit for the needs of shipping.

Another disadvantageous feature exhibited by delta ports is found in the frequency with which the principal path of exit of the river waters changes its position. By reference to a map of the Mississippi delta or those about the mouths of other sreat streams, it will be seen that the river commonly has a number of separate ams by which its flow may escape to the sea. In most cases detailed study shows that only one of these exits is at any particular time the seat of the principal stream. The others have been temporarily abandoned, but may from time to time be reopened by the varying movement of the waters. Hyclrographers who have studied the laws of river movement recosnize the fact that these delta channels are naturally, indeed we may say necessarily, subject to changes in position. When after a time an outlet has extended in the manner of the present channel of the Mississippi for a considerable clistance seaward, the energy of the current is slackened by the lengthening of the slope over which it mores, and so the flood waters begin to rise to a greater height in the up-river portion of the delta than they 
did before. Finally, they find their way by some shorter cut to the margin of the land, and, for the reason of the shorter distance, the slope over which they flow is steeper than that they have before pursued. Moving rapidly down the decline, the water soon cuts open a new channel through which it has for a time a freer exit; the old and longer way then gradually silts up, until it has no value as a pathway for the stream or as a port.

The changes of channel which occur in a delta district are often of formidable commercial importance. Thus the Yellow River of China in 1853 opened a new outlet to the sea, the mouth of which was some hundreds of miles from that of its former path. At the present time the main outlet of the Mississippi tends to change its place in the manner and for the reasons above suggested. In general, it may be said that a few centuries represent the time during which a delta mouth will normally maintain one position.

It is possible by means of engineering devices to overcome some of the most considerable defects and dangers which beset delta ports. The obstacles to upward navigation due to the current of the stream, a hinderance which is often of a serious nature to sailing vessels, may be met by the use of steam tugs. Such accidents as the change of channel, which may at any time cut off the city which develops at the port. and leave it in an unprofitable position, can be indefinitely. postponed by engineering devices. The most serious objection to this class of harbors, that due to the broad platform of mud forming widespread shallows just beyond the margin of the delta land, is more difficult to meet. For a long time it seemed an insuperable difficulty, for the reason that. although a channel might be cut open by artificial dredging, 
the action of the waves in times of storm, actded to the work naturally done by the river. operated rapidly to close the opening. A method of meeting this difficulty has been found, however, and has been successfully applied to the delta mouths of two great streams, the Danube and Mississippi. It was first invented and applied in the European instance, but it has been used with the greatest success by an American engineer, Capt. James B. Eads, in securing a deeper ship channel leading to the port of New Orleans.

In the method of improvement above referred to, the bounclary walls to the channel are continued for some distance beyond the point to which they have attained in the natural extension of the delta. They are in fact led across the mud flat which forms beneath the sea beyond the edge of the marshy land, until the sloping bottom has attained a sufficient depth of water for the convenience of incoming ships. The principal disadrantage of the method is found in the fact that the sediments brought down by the river frequently settle next to the artificial mouth, as they dicl in front of the natural opening, so as to require a constant building of the jetties towards the sea. There is, of course, a limit to the convenient cxtension of the stream mouth in this artificial manner, but for years the scouring action of the current deepens the water of its enforced channel, and so makes the entrance and the path of the stream suitable for commercial needs. In the course of time it will probably be necessary to open another and shorter pathway of escape for the Mississippi, or to provide an artificial entrance by means of a canal leading from the river to the sea, but there seems no good reason why this channel should not be so selected as to preserve the city of $\mathrm{New}$ Orleans as the port for the sea-going 
commerce of the stream. Thus these modern improvements in the way of towboats and jetties promise to avoid all really serious inconveniences connected with delta harbors.

Ports of the class which we are now to consider resemble those just described, owing their origin to the work done by consiclerable rivers. In every other particular, however, their features are peculiar. The havens belonging in this second group are formed where a river valley was carved in the land at a time when the surface of the country in which it lies was at a considerably higher level than at present. The depth and form of the gorge so excavated by the flowing stream may have varied greatly. In most cases we may assume that there was a delta at its mouth like those formed at the mouths of all great rivers along shores which have not recently sunk down. When the coast line subsided, say to the depth of one or two hundred feet, the sea was permitted to enter the valley for a distance dependent upon the degree of its slope and the amount of the downsinking of the land. Under these conditions the path of the river next the sea is considerably shortened, and at the head of the bay thus formed the stream begins to make a new delta, which in time may completely close the reëntrant formed by the subsidence.

At first sight it may seem as if this were an improbable means whereby harbors could be formed, but the fact is that a large number of the great commercial ports, both in this country and in Europe, owe their origin and much of their value to such vertical movements of the land. The most important havens on the Atlantic coast from New York to the Rio Grande, and probably many of those on the Pacific shore of the United States, doubtless owe their formation to this subsidence of the shore lands. Delaware and Chesapeake 
Bays, Pamlico and Albemarle Sounds, the harbors of Charleston and Savannah, and Mobile Bay afford perhaps the best instances of this class of havens. At the time when the subsidence which produced these reëntrant delta harbors took place, the valley of the Mississippi was occupied by the greatest of these bays, which probably extended for several hundred miles above New Orleans and had at some points the width of fifty miles or more. Owing to the very large amount of detritus which that stream bears to the sea, the whole of the reëntrant has become filled by the newly formed delta, and the accumulation now projects beyond the ancient valley and thus has the normal form of such deposits.

It is characteristic of the ports which are formed in these flooded valleys, that they were originally wide-mouthed, and narrowed gradually toward their head waters. In many instances the passarre from these basins to the sea has become constricted by the formation of sand spits, built in the manner hereafter to be described. Owing to the plentiful incursion of river waters heavily charged with sediment, the harbors of this group are apt to become shallowed, and, except so far as they are kept open by tidal currents, are often unfitted for the use of large ships. This shallowing of the water is likely to be most conspicuous in the parts of the basin near the existing mouth of the true river. It occasionally happens, that, while the floor of the bay over the greater part of its extent has been converted into shoal water, some of the side gorges origrinally occupied by small streams retain a great depth of water. Perhaps the most notable instance of this kind is afforded by Albemarle Sound. Where this estuary traverses the Dismal Swamp, its main channels have, at low tide, only four or five feet of depth, but the waterways which penetrate 
into the Dismal Swamp, where they receive little or no detrital matter even in times of heavy rain, occasionally retain a depth of twenty or thirty feet, their bottoms lying even beneath that of the neighboring parts of the open sea.*

Few save those who have made a special study of greology have any clear idea concerning either the nature or frequency of those movements which take place in the shore districts of the greater land masses termed continents. It therefore may aid the reader to understand the extent to which havens are formed by the submergence or flooding of old river valleys, if he is presented with some of the more important acts and conclusions concerning these curious movements. It is well at the outset to understand, that although there is much evidence to show that from the earlier geological ages the continents have existed as areas of dry land, that of North America, for instance, having been a geographic unit since the Carboniferous Period, or, at most, with its eastern and western parts divided by a narrow sea, the outlines of this and other lands have been subject to frequent and extensive changes of level. Thus in the geologically brief period since the beginning of the last Glacial Epoch, or, as we may fairly term it, since the morning of the geologic yesterday, all the eastern coast of North America has swayed up and down in several successive oscillations ranging from a few score to a few hundred feet. At the beginning of this last ice age the northeastern portion of the continent was evidently somewhat higher than it is at present. When the weight of the ice lay upon the land, it sank down so that the depression along the coast of New England as compared with the present level of the sea was

* See General Account of the Fresh-water Morasses of the United States, by N. S. Shaler. Tenth Annual Report, pp. 327, et seq. 
two hundred feet or more. Somewhat later this region was elevated to a height a little above its present level. This resurgence from the deep was followed by yet another downsinking. probably of relatively slight amount, but sufficient to carry many areas of forested lands below the level of the tide.

In the region about the Dismal Swamp of Virginia, the present writer has ascertained that there have been at least three periods of successive elevation and subsiclence, during which the land swayed up and down through a range of about fifty feet of altitude within a period which is probably to be reckoned as of no greater duration than the time that has elapsed since the last great invasion of ice began in the northern part of the continent. Athough the study which has been applied to the subject of land swayings is still very incomplete, the results are sufficient to assure us that such instances as have been given are by no means exceptional. They have been indeed common in all stages of the earth's history which are legibly chronicled in the pages of the great stone book whose leaves are the strata of the earth's crust. It is probable, however, that these movements of the land are often greatest next the shores; they may indeed occur there without corresponding alterations in the level of the interior parts of the continent.

As yet geologists have not satisfactorily traced the several causes which coöperate to bring about these upward and downward movements of the earth's crust. They have, however, become convinced that the old idea to the effect that the land masses were in some way permanently and rigidly upheld. like the arches of solid masonry, is an error. They are driven to conceive these parts of the crust which are above the level of the sea, as well as much of the ocean floor near the con- 
tinents, to be in a state of very unstable equilibrium, casily swayed up and down by forces which operate in the onter part of the earth or upon its surface. Thus when the glacial sheet was laid upon the northern lands the effect seems to have been to bear down the surface of the earth on which it was imposed, to a depth in a way proportionate to the thickness of the ice. When the glaciers melted away the de. pressed areas quickly recovered their position, and, as we have noted above, rose even higher than they are at the present time. The accumulations of sediment washed from the land and deposited on the sea-floor appear also to bear down the surfaces on which they rest, in substantially the same way in which they are affected by the burden of a glacial envelope. On the other hand the removal of weight from the land by the action of rain-water, by which rast quantities of material are taken away, appears to faror the constant uprising of the land, so that, though endlessly. down-worn by the action of the elements, the continents remain ever undestroyed.

As the central parts of the earth are constantly shrinking from the loss of heat, while the portion next the surface remains unshrunken for the reason that it has long since parted with the greater part of its caloric, the outer envelope of rocks has constantly to wrinkle into the broad upcurves of the continents and downcurves of the sea-floor in order to fit itself to the diminished internal mass. The action may be in a measure paralleled by that which takes place in an apple. the skin of which wrinkles as the juice dries away from the inner parts. The folding of the outer envelope is due, as we readily perceive, to the fact that the interior of the sphere shrinks much, while the outer part thereof does not contract 
and therefore has to fold. It is evident that when a continent has begun its growth the tendency is for the upward arching curve to continue growing in that direction, while the downward flexures of the sea-bottoms in the same general way persistently tend to grow deeper. It is easily to be conceived that in such a movement of uprising land and downsinking sea-floor we necessarily have a neutral or fulcrum point of the motion, in the manner indicated by the diagram. The

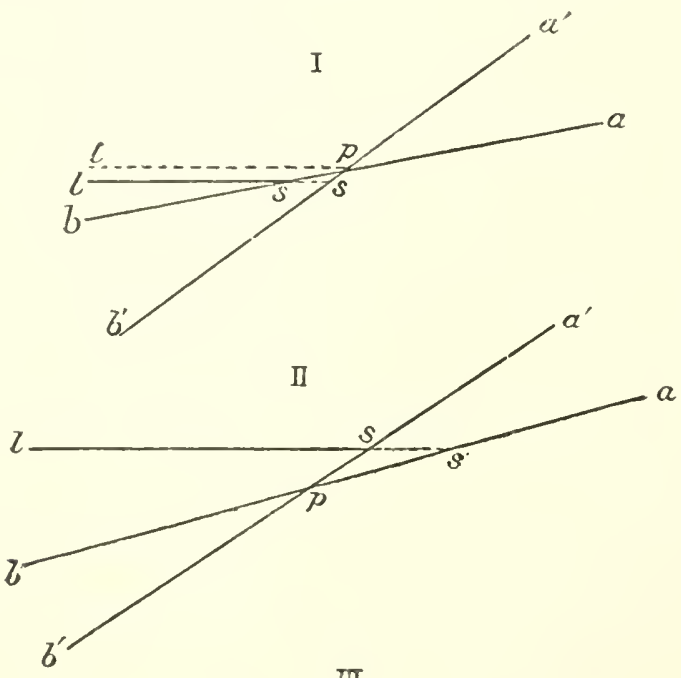

III

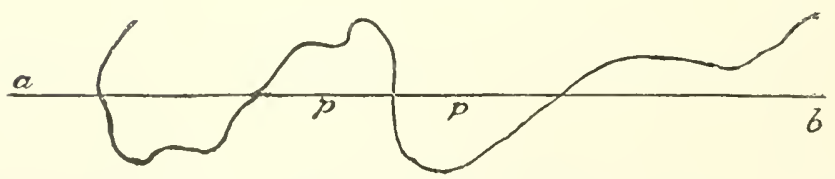

In diagrams 1 . and II. the lines $a b$ represent the land before the movement, and $a^{\prime} b^{\prime}$ represent the land after the movement; $s s$ the position of the shore-line : $p \phi$ the pivotal points : $l s$ the sea level. In diagram III. the curved line designates a shore, the line $a b$ connecting pirotal points at $\not p$, the pirotal line partly under the land and partly under the sea.

neutral point, or position of no motion, on a line extending from the interior of the continents to the areas of the neighboring sea-basin, may occupy either of three positions in relation to the shore-line. It may be just at the coast, in 
which case a good deal of upward and downward movement at either end of the section may take place without any alteration in the position of the shore-line, or the pivotal point may be some distance within the land, in which case the movement may lead to a gain of the sea upon the continent. In the third possible condition the point of no motion may be seaward of the shore, when, though the nature of the movement may be exactly the same as before, the coast-line will rise and the land gain upon the sea.

In the way above suggested we may account for the frequent changes in the direction of the movement which occurs in those parts of a continent which are near the shoreline, without having to suppose that the whole mass of the continent undergoes like changes of level. The inland districts may be in a somewhat constant manner rising into the air, while the coast-line, owing to slight accidental changes in the position of the fulcrum points, may be subjected to constant oscillations of movement.

If the sea-shore remains in the same position for a long time, the ordinary effect of the coast-line actions is to close the harbors, either through the accumulation of débris brought into them by the streams or by the sands which the waves and coastal currents are continually impelling into all the recesses of the shore. IVhere such conditions occur we may reasonably expect to find a coast to a great extent destitute of harbors, though we may trace the evidence of their former existence by noting the basins filled with alluvium which exist along the margin of the land.

Where any coastal region is without considerable rivers, and where there are no conditions such as we have hereafter to describe which lead to the formation of indentations, 
we commonly find that there are lut few and inadequate shelters for ships; thus on the west coast of the Americas from northern Mexico to southern Chile, an essentially riverless region, embayments suitable for havens are very rare. Similar conditions prevail in all the seaboard regions near the great deserts of north Africa. Although these shores are subject to constant oscillation, they have no large troughs such as the rivers cut on other coast-lines which may be filled by the sea waters during the periods of subsidence. Where the river valleys are deep the accumulations of dibris formed in them during the periods of temporary subsidence are often not sufficient to obliterate their form. Thus, in the case of the Hudson and other valley's along the east and west coasts of North America, the depression occupied by the stream in former periods of elevation is still traceable as a deep trough for fifty miles or more into the sea. If the shore near New York were elevated even as much as two hundred feet, the reëntrant of the Hudson Valley would still appear as a deep bay and afford, as it does at present, a serviceable port. Thus it comes about that in periods of elevation, as well as of depression, the irregularities of the coast-line, due to the action of rivers, serve to maintain the varying outline of the shore on which the existence of harbors depends. While there are many other actions which operate to bring about the formation of harbors, this which we are now considering is probably of more general importance and affects a larger part of the coast-lines than any other class of actions at work along the shores.

In certain parts of the world in regions of high latitude, we find the coast-line fretted with very numerous channels which often penetrate far into the land, while the shore for 
some distance seaward is bounded by a fringe of rocky islands. Shores of this character are common in the northern hemisphere from the parallel of $40^{\circ}$ to near the Pole. 'They we noticeable also in the southern part of the earth along the coasts south of the same parallel. The feature is less conspicuous near the southern Pole, for the reason that the greater portion of that realm is occupied by the sea. The people of the Scandinavian peninsula have long applied to the deep inlets of that coast the name of fiord. Geologists therefore apply the term to all indentations of this character wherever they are found, and to the regions in which these inclentations characteristically and plentifully occur they give the name of fiord zone.

In their form the indentations of the coast in the frord districts differ wiclely from those which belong to the other classes which we have already considered or have hereafter to note. Where best developed this class of inlets exhibits the following peculiarities: The valley occupied by the embayed waters is remarkably cleep. The shores are steep, so that a cross section of the trough is distinctly $U$-shaped. If the region in which a fiord lies be elevated, its sides may rise as in Norway to mountainous heights, but indentations of this description occur even where the shore lands attain to no great height above the sea. In characteristic fiords the water within the basin may have the depth of many hundred feet; tracing a line of soundings from the interior of the fiord seaward, the water is often found to shallow near the entrance of the indentation until the depth is only a small fraction of that which exists in the land-locked parts of the valley. This sill or barrier near the mouth of the inlet is a frequent but by no means an invariable feature in the fiord 
structure. It is most distinctly presented in the case of the greater indentations bearing this name which lie along the coast of Norway. Where the valleys of this nature are less accented, as along the eastern coast of North America, there is barely a trace of the sill or ridge between the basin and the sea, or it may be altogether absent.

While in the main the fiord channels lie at right angles to the coast-line of the sea into which they open, each of these basins commonly exhibits numerous side bays extending more or less nearly at right angles to the axis or main line of its trough. It generally is evident that these ramifications of the fiord are cut in the softer rocks or in the weak places of the strata against which they lie. Where the side embranchments of one fiord come in contact with those of another and the valleys are cut to a sufficient depth, their waters may be confluent and islands are formed. 'Thus it comes about that in passing from the sea towards the firm land of a fiorded coast there are usually encountered first a fringe of islands and then the embayments which penetrate the body of the land. A rational consideration of the facts shows us that islands and bays alike are due to the same caluse. While it is easy to perceive that the conditions which have determined the formation of fiords are peculiar, much difficulty has been encountered in arriving at a clear conception as to the nature of the forces which have excavated them. Although their origin is yet under debate, the facts point to the conclusion that fiords are mainly, if not altogether, due to the peculiar kind of wearing which takes place beneath a glacial sheet.

In examining the question as to the origin of fiords we should in the first place note that this class of indentations 
is limited to the regions which were during the last glacial epoch occupied by long-encluring ice, as is indicated by the existence there of drift material, such as glaciers alone could form and transport, and by the characteristic scorings on the rock surfaces which glaciation alone can cause. This approximate coincidence between the field occupied by glaciers and the shores abounding in fiords is of itself sufficient to raise the presumption that this fretting of the shore is due to ice action. This presumption is strengthened by the fact that the fiords are deepest and of most characteristic form in those parts of the world where we may fairly suppose the glacial sheet to have been the thickest and to have remained active for the longest time. Thus in Scandinavia and Scotland, in Greenland. Labrador, and Alaska, in the extreme southern part of South America, and in New Zealand, the fiord structure is greatly developed, while in the parts of those fields which, though somewhat glaciated, lie in latitudes nearer the equator the fiords are carved to no great depth. In other words, where the ice was thick and abided long the peculiar carving of the land characteristic of the well-developed fiords was the greatest, while in the regions in which the ice action was relatively weak the valleys were excavated to a much less depth.

We furthermore note the fact that the form of surface which along the coast-line gives rise to fiords is not peculiar to the shore lands. It extends back for an indefinite distance into the interior of the land in the latitude in which these fringed shores occur. In a less distinct way it is also continued for some distance seaward beyond the present margin of the water. In other words, the fiord belt is not clue to some peculiar action which has taken place along the existing 
shore-line, but it owes its origin to a general character which is stamped upon a large part of the lands that have been erocted by glacial action. It is also clear that the institution of fiords does not depend rypon such carving of the land as maly be brought about ly ordinary river action. If we compare the character of the rocks in the peninsulas of Spain and Scandinavia we find that the strata of the two regions apparently do not differ from each other in any essential way, at least as regards their resistance to the erosion effected by rain-water; but the northern of these two areas everywhere exhibits a fiorded coast-line while the shore of the more southern land is as characteristically exempt from this peculiar topography. In the same way, on the western coasts of North and South America the extreme northern and southern parts of its extent are extensively fiorded, while the intermediate section from the mouth of the Columbia River to $\mathrm{V}$ alparaiso forms one of the least indented shore-lines in the world.

Not only are fiords limited to glaciated areas, but the general topography upon the existence of which their presence depends can, so far as we know, be created only by a gracial action. As we have just noted, it is characteristic of well-developed fiords to have a basin- or bowl-like character in the upper part of a reëntrant, and an elevation or sill between this chepession and the sea. Now it is a well-known fact that in glaciated countries we always find more or less numerous lakes having essentially the same shape as the fiord basins; deep depressions, rock-walled on every side, are among the most familiar results of extensive glacial wearing. The eastern portion of North America abounds in such depressions, and they are extensively developed in the valleys of Switzerland, where we know by indisputable evidence that 
glacial work has been very extensively done in recent geologic time. It is indeed characteristic of glacial wearing, as distinguished from the erosion effected by flowing water, that the ice can carve out depressions in the rock. If we examine any consiclerable area which was worn by ice, we find everywhere pits upon its surface, which may be from a few feet to a hundred feet or more in depth. Owing to the essential plasticity of ice it can, when moving in the manner of a glacier, descend into and rise up from tolerably deep depressions; it will, indeed, deeply carve out any soft portion of rock which it may encounter, leaving the surrounding materials as a rim to the basin. While it is true that only a small part of the lakes which beset the glaciated country of North America are due to the fact that the water is contained in basins completely surrounded lyy firm-set rock, there can be no question that there are thousands, if not tens of thousands, of such cavities on the glacially worn surface of this country.

It is a noteworthy fact that the form of the fiord basins is essentially the same as that of our glacial lakes which are surrounded by rock margins. The fiords, which are characterized by a sill or barrier rising to near the surface of the water on their seaward side, may be regarded as basins essentially like those which are occupied by the rockbordered lakes, the outer margins of which are slightly submerged below the level of the sea. The fact that these basins are due to rock-carving and in no considerable measure to river action is clearly shown, as I have elsewhere indicated, by the arrangement of the fiords on the islands of Mount Desert, Maine.* To a certain extent these basin-

* See Geology of Mount Desert, Eighth Annual Report United States Geological Survey, pp. 1005-1009. 
shaped valleys, formed by glacial erosion, are related to those which are produced by ordinary rivers. In part, the cutting action accomplished by the glacier is performed by streams of fluid water coursing beneath the ice and moving forward with the violence which the weight of the overlying frozen water gives to their flow. Unlike ordinary rivers, these streams beneath the ice flow up hill and down as they follow the devious outline with which the sheet of frozen water rests upon the surface. Athough the carving of valleys is in part accomplished by these subglacial streams, the work is cloubtless in good part done by the abrading action of bits of stone which are contained in the slowmoving ice.

In many if not in most cases, fiords are doubtless produced where river valleys, which existed before the glacial period, have been deepened and widened by the flowing ice. Owing to the fact that a glacier in general cuts with a measure of energy proportionate to the depth of the ice above the particular point, the tendency of the action is generslly to wear down the bottom of the valleys more rapidly than the intervening upland country. At the same time, owing to the width of the slow-moving current, the channel is widened far beyond the limits given it by the river which formerly flowed in the gorge. If the ice action be long continued, all distinct trace of these ancient rivers may be effaced, but in the greater portion of southern New England, where the glacial wearing was relatively small in amount, these old streamways are still evident and with shapes not greatly altered from their pre-ylacial form. Thus the principal fiords from New Jersey to Nova Scotia are manifestly old river valleys which have been somewhat 
modified by the ice stream which recently occupied their beds.

In their characteristic development in high latitudes fiords offer singularly good harbors for ships. The main channels, however, are often too deep to afford safe anchorage ground, but in the shallower branches of these bays it is generally possible to find perfectly landlocked havens exactly suited to all the needs of shipping. Inlets of this clescription are, as a rule, admirably protected from the action of those arrents which tend to destroy many other harbors. The streams that enter them rarely convey any considerable quantities of sediment which might effect a shallowing of the basin. The waters of these rivers are unmingled with sediments, for the reason that they flow from drift-covered countries which send little muddy matter, and, moreover, the streams themselves commonly pass through lake basins which afford settling pools for such sediments as the flood waters may bear. The fringe of islands which commonly lies off the shores of a fiorded district often affords shelter of a valuaable sort for craft which are undertaking coastwise voyages. Thus for the greater part of the distance from Portland to Eastport, Naine, it is possible for small craft to journey without being exposed to the ocean waves, within the pas: sages between the islands and the mainland. The protection afforded by such island fringes is even more continuous on the western coast of North America, where the barrier of islands extends from Puget Sound northward for a distance of more than seven hundred miles, with but slight breaks which expose a vessel to the open sea.

The effect of a well-developed fiord structure is greatly to increase the length of a shore-line. The measure of this 
extension, even where the fiords are only morlerately devel. oped, may be judged by the following examples. The direct distance from Portland to Calais, Maine, is only a little over two hundred miles, but the aggregate coast-line of mainland and islands between these two points is more than ten times as great. The beautiful fiord termed the Bras d'Or on Cape Breton, an island at the eastern extremity of Nova Scotia, though one of the smaller inlets of this description, is said to have an aggregate coast-line, including the periphery of the islands which it contains, of more than one thousand miles. The aggregate length of the coast-line of the Scandinavian peninsula and its associated islands is probably much greater than the circumference of the earth. We understand, therefore, how it is that the people who dwell on coasts of this clescription naturally become trained for a seafaring life.

The indentations of the shore which are to be considered as belonging to this class are formed where the upfolded strata which constitute mountain ridges lie in such a position that the sea may penetrate for a greater or less distance between the axes or lines of the elevations. Almost all mountainous belts are composed of such more or less distinct ridges, separated by equally definite troughs. In general the mountain ranges of any country run parallel to the shores near which they lie, but it occasionally happens that the end of such an association of elevations and furrows abuts against the sea, in which case the ocean waters may enter the valleys for a sufficient distance and form considerable bays. Instances of this nature, though rare in North America, are frequent in the Old World. Thus where the western extremity of the Pyrenees, or rather the western prolongation of that range, comes to the Atlantic at the northwestern angle 
of the Spanish peninsula, a number of bays lie between the projecting mountain spurs; so, too, the deep embayments of Greece appear to be the flooded valleys which lie between the numerous mountain chains of that country, while a large part of the islands of the Archipelago are made up of peaks belonging to those portions of the same ranges which lie mostly below the level of the sea.

Occasionally where mountains run parallel with the seashore near which they lie, some of the ranges are so placed that their parallel valleys may be low enough to receive the waters of the sea and thus form straits between mountainous islands and the mainland. The elongate islands which border the eastern side of the Adriatic appear to belong to this class of inlets. On the coast of North America the only conspicuous instances of this kind occur along the Pacific coast, of which perhaps the most characteristic is that of Victoria, lying immediately north of Puget Sound. A closely related group of harbors formed by the projection of peninsulated mountain ranges into the sea is well illustrated by the promontory of Lower California. Owing to the large scale of these inlets formed by the projection of mountain ranges into the sea, or islands extending parallel to the shore, made by the summits of ranges which are in good part submerged, the waters which they enclose are generally too extensive to serve the best uses of havens, though they are sometimes valuable as roactsteads where ships may at least be sheltered from the heavier waves. Inlets of this description are much more common on the coast of Europe than on the shores of North America, for the reason that the mountain ranges of the former continent are more numerous and more frequently come to the shoreline than in the New World. 
At the front of every glacier there is accumulated a mass of rocky débris which is shoved, dragged, or carried by the ice and dropped at its margin. The vast ice-sheet which recently covered the eastern coast of the continent as far south as New

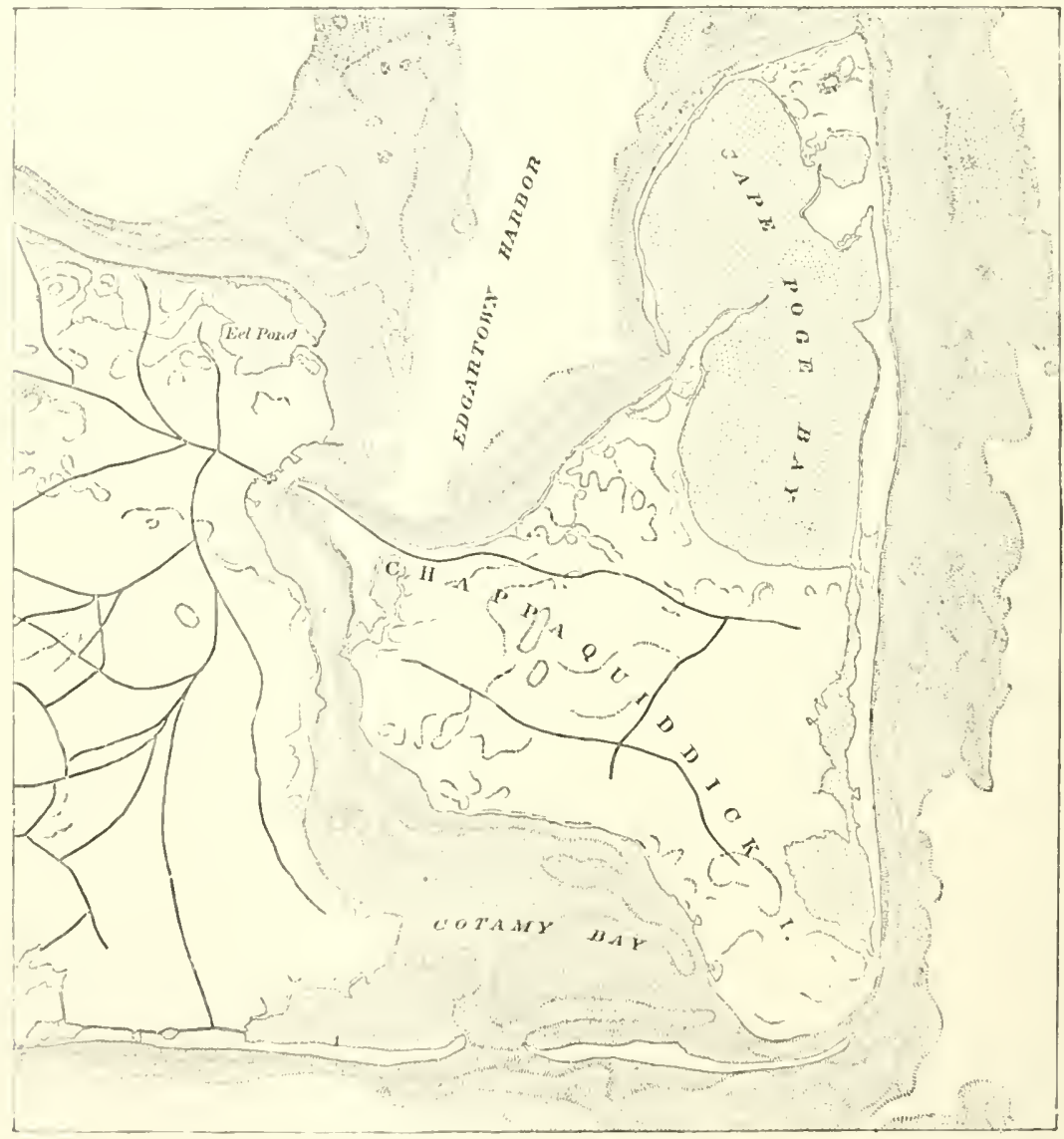

Edgartown Harbor, Martha's Vineyard

Jersey here and there built these morainal accumulations to a great height. During the greatest extension of this icesheet its edge passed beyond the shore at New York and lay beyond the coast from that point for an undetermined dis- 
tance northward. The greater part of the accumulations which were formed along this outer edge of ice lie beneath the level of the sea. Here and there, however, they project above the water, forming islands which may be of consiclerable elevation. Nearly the whole of that part of Long Island, New York, which lies above the sea level is made up of such moraines. The greater part of Martha's Vineyard, Nantucket, and Cape Cod are of the same nature. North of the lastnamed cape the more advanced moraines almost everywere lie wholly beneath the surface of the sea.

As the glacier retreated it constructed many of these parallel walls of débris, separated from each other by intervals of greater or less width. It occasionally happens that the sea penetrates into these low grounds between the morainal walls and thereby forms considerable bays. The sheltered waters about Sag Harbor at the eastern end of Long Island, New York, were formed in this manner. Harbors of this nature are generally shallow, and, save for the protection afforcled by the scouring action of the tide, are almost certain to become filled with débris washed from the cliffs of drift materials which rapidly yield to the assaults of the waves and currents.

At the time when the moraines were formed there were flowing from beneath the ice considerable rivers which cut deep channels through the walls of bowlders, sand, and clay which constituted the moraines. Where the sea enters these channels it not infrequently forms harborage grounds of considerable value. Thus on the southern shore of Massachusetts there are a number of ports lying in these depressions which were scoured out by the rivers flowing from under the ice. The havens at Edgartown, Holmes' Hole, Wood's Holl, Quick's Hole, Robinson's Hole, are instances of this nature. 
These harbors are generally shallow and are not completely landlocked. Inasmuch as they lie amid drifting sands they are likely to be rapidly shallowed unless carefully guarded from the invasion of sediment by engineering skill. Although these inlets, as compared with those produced by other agents, are of relatively little size and not well suited to afford shelter for ships, they occur on parts of the coast which are otherwise without havens, and on this account have a considerable economic importance.

Besides the morainal deposits, the glacial sheet left upon the country which it had occupied a vast amount of drift materials disposed in an irregular manner, so that the resulting surface of the earth consisted of innumerable ridges and valleys. At the close of the ice period the sea, penetrating into the depressions of the surface, formed innumerable shallow bays. The greater portion of these has been filled with sediments or closed by the growth of marine marsh deposits. Here and there, however, they still afford shallow harbors, in most cases suitable only for small vessels engaged in shipping or in coastwise traffic. Wareham and Chatham harbors on the southern coast of Massachusetts are good instances of this peculiar variety of havens. Farther north on this continent and in the glaciated districts of Europe about the North Sea, inlets of this nature are of common occurrence, but as they lie in districts provided with shelters for ships by other and more effective haven-making agents, they have little value to mariners. 


\section{THE FORMATION AND PRESERVATION OF HARBORS}

Lagoon Harbors; their Origin and History.-Effect of Wind-blown Sands.-Sand-Spit IIarbors.-Effeet of Water-borne sands.-Crater Harbors.-Coral-Reef Harbors; Division into Two Classes; Ways in which constructed.-Preservation and bestruction of IIarbors: Ways in which they act; Tidal Action; Changes of Level ; Accumulation of Sediments; Invasion of Marine Waste.-Relative Importance of Damaging Agencies in Lake and Sca Ilarbors.-Effect of Pocket-Beaches.

MIEREVER the water next a shore is shallow and the bottom sandy and the waves have considerable strength, we find a series of elongate low-lying islands which more or less completely enclose a shallow field of waters commonly termed a lagoon. Although sand-bar islands of this description frequently occur along the shores of other continents, they are perhaps most characteristically exhibited on the eastern coast of North America. From the high north soutluward along the shore to Portland, Maine, the water is so deep and the bottom so free from sand that the waves moving toward the shore do not obtain possession of sufficient detritus to form extensive barriers of this description. Soutin of Portland and thence to Cape Florida these sand reefs are so generally developed that they form a tolerably connected barrier between the mainland and the open sea. From the waters of Chesapeake Bay to those of Biscayne Bay, a distance of about seven hundred miles, this natural rampart of sand is so continuous and the lagoons which it shelters so 
connected, that one may journey in a small boat nearly all the way without being exposed to the open sea.

The lagoon bar element in our shore-line topography is so important, both from the point of view of science and that of economics, that the reader should attain a clear understanding as to the manner in which these bars are formed. IV e shall therefore examine in a somewhat detailed way the process of construction. Whencver these reefs abound next the coast, we find on examining charts of soundings which depict the shape of the bottom of the neighboring sea that the coast is bordered by a wide belt of shallow water which extends as a gradually inclined plane, declining toward the open ocean with a descent of from five to ten feet to the mile, its surface covered with tolerably fine sand, mingled with the déris accumulated by the marine life which inhabits the ocean floor. From a line commonly lying from fifty to one hundred miles from the coast, this broad, gently sloping continental shelf suddenly declines into deep water, its outer margin often having a slope of one hundred feet or more to the mile. It is clearly recognized by geologists that this continental shelf is in the main made up of debris worn from the land which has been distributed over the sea-floor by the action of currents and waves, operating through a number of geologic ages, during which the shore, although occasionally rising and sinking in slight oscillations, has maintained nearly its present position.

Wherever this continental shelf is well developed beneath the sea we are likely to find that a portion of the terrace built during periods when the coast was somewhat lower than at present extends inland in the form of broad, slightly rolling, sandy plains. Such an emerged portion of the con- 
tinental shelf borclers the shore from near New York to near the Rio Grande. Similar areas of recently emerged shallow sea bottom occur on almost all the extended sea-coasts of the world, though they are perhaps nowhere else so well exhibited as in the southern seaboard states of this country, where the present coast-line happens to lie near the middle point in the slope of the continental shelf.

As the form and structure of this continental shelf clearly indicate that the materials have been arranged by wave action, we can readily understand how portions of the detritus may be thrust against the shore by the heavier waves which run from the deep sea toward the coast-line. It is important, however, to perceive in just what manner the ware does this work. We should first note the fact that in the deeper parts of the sea a wave of the first magnitude, though it may have a height of as much as fifty feet from trough to crest, is essentially a superficial movement of the waters, in which the particles of the Huid do not go forward in any considerable way, but merely revolve in a kind of orbital movement. The wave motion which we make in shaking a carpet is in all essential respects comparable to that of an ocean surge where the water beneath its base is a mile or more in depth. Nuch as the surface of the ocean is heaved and tossed by these waves, the amount of movement imparted to the water is slight. If we could observe what takes place on the sea-floor, five thousand feet below the tempest-swept surface, it would require instruments of exceeding delicacy to indicate the trifling motions which the waves produce.

As the waves from the deeper seas attain the shallow water next the shore-say, when they come where the sea has 
a depth of five hundred feet-they begin to have a sensible effect upon the bottom, operating to brush the finer materials in the direction in which the surges are moving; attaining yet shallower water, this rubbing action is proportionately increased. At the depth of a hundred feet the effect of these wares in sweeping sands in toward the shore may be considerable. The action is probably of sufficient energy to drive even small pebbles up the slope toward the land. Owing to the friction which the front part of the wave encounters beyond that which the following part meets as it passes over the upwarl slope of the bottom, the surge becomes ever narrower in cross section as it approaches the shore-that is to say, it is higher in proportion to its width. As this friction of the bottom of the wave on the floor of the sea increases, the upper part of the surge, for the reason that the fluid there is less hindered in its forward movement by the resistance of the bottom, shoots forward, quickly acquires a wall-like front, and finally its upper part flies clear beyond the base and combs over in the form of a "roller." Owing to the long-continued friction on the bottom which the wave has encountered in its morement over the shallows toward the shore, its volume and energy are commonly very much reduced from the conditions presented in the open sea. L'sually the surge when it breaks upon the shore has not more than the fourth to the tenth of the power which it had in the water a thousand feet deep. Nere it not for this loss of energy, the effect of the ocean surges on the land would be vastly greater than it usually is.

II'atching the action of ocean waves along a gently sloping shore, we observe that the lesser undulations, such as 
occur when the sea is affected only by in-shore winds of slight energy, break very near the water-line. Heavier surgessay, those having a height of three or four feet-comb and fall over at a distance of some scores of feet from the actual margin of the sea; while waves of the greatest volume, such as are formed at rare times of heavy tempests, may break a mile or more away from the strand. ITherever the overturning occurs, the power of the wave is broken and whatever debris it may have been urging forward is left upon the bottom. If we clearly perceive these features in the action of waves, it is easy to understand how the bar islands which enclose lagoons are formed. Thus in case our southern shore should be depressed below the level of the sea, so that the barrier sand reefs were covered, a result which would be produced if the region were lowered to the depth of thirty or forty feet below its present level, the immediate effect would be to bring the ocean waters into free contact with the shore of the mainland in a manner found on coast-lines where there are no such outlying islands. At once the submerged barrier would be taken to pieces by the waves, and the accumulations of sand would be spread over the bottom of the sea, still further shallowing the water near the shore. II ith the advent of the next ensuing great storm the waves would break at a clistance from the shore; it might be even some miles away from it, and on this new line of breakers the construction of a new series of barrier sand reefs would begin. If the storm were great, so that the waves, were of the first magnitude, the breaking might take place in water having a depth of as much as fifty feet. Waves of a volume to break in water of this depth would carry a good deal of sand to the point where they topple over. Here this transported detritus 
would lodge, and if the storm were long continued the sands might be built up to a sufficient height for the ridge to emerge above the level of the sea and form a beach. Unless this emergence of the crest were effected, the succeeding storms of lesser energy would tend to destroy the imperfect barrier by sweeping waves over its crest without breaking, in which case, as will be readily perceived without further explanation, they would tend gradually to scour away the elevation, distributing the sand between its position and the neighboring shore. The shallowing of the water thus brought about might go on by the successive temporary formation and distribution of submarine sand reefs, until finally, in some great storm, a ridge was built up of considerable length, perhaps along a great distance of shore, which rose above the level of ordinary low tide. When such a ridge had been so formed, high enough to escape the scouring action of waves of any considerable magnitude, operating by overrunning its top, each succeeding storm, even those of ordinary energy, would tend to add to the mass by bringing in more sand from the continental shelf.

As will be noted hereafter, the inner portion of the continental shelf, the part which lies in shallow water next the shore, commonly receives considerable contributions of sand, which work along the coast from regions beyond the limit of the barrier reefs. Thus on our Atlantic coast a good deal of arenaceous material may have journeyed from as far north as New Jersey, where it was contributed to the sea during the last glacial period, or washed into the ocean from deposits of sandy matter formed during the ice time. In this way the waves can continually bring in sandy matter without diminishing the depth of water on the out- 
lying shallows. So far as depends upon the action of the waves the coastal sand islands cannot rise more than a few feet above the level of low tide; but as soon as a beach is formed, the winds operate to form sand heaps or dunes above the level of the sea, which may considerably increase its elevation above the ocean level.

The wind-blown sands of these wave-built islands play an important part in the history of our sandy shores. Even before the barrier ridge has attained to a sufficient height above the tide to give a foothold for land vegetation, the formation of these dunes begins. When the tide is out a broad section of the beach is left bare, the superficial sands of which in an hour or two become dry enough to be blown in-shore whenever the winds come strongly against the coast, and moving up the slope of the beach they form a ridge parallel to the coast-line. As long as the sand is on the slope of the dune toward the sea, it is exposed to the wind and is likely to be kept in motion. When it passes the crest of the elevation it drops into a lee and comes to rest; at least until the wind changes direction so as to again obtain possession of it. As soon as the land vegetation fitted to grow in such places obtains a foothold on the island, the growth of the dunes is favored by the fact that the sand catches amid the stems and leaves and becomes tied together by the roots, so that the occasional storms from the land, in most cases less energetic than those from the sea, cannot blow it back into the ocean. Under these conditions the wind-blown materials may accumulate in sharp ridges, which attain a height of from ten to a hundred feet or more.

Although the species of plants, such as our beach grass of northern dunes or the dwarf palmettos and other plants of 
the southern coast have, by long education, become well adapted to the peculiar task of holding wind-blown detritus, much of the finer arenaceous material is blown across the sand hills next the sea and distributed in a more sheet-like form over the lagoon which lies between the growing barrier and the mainland. This accumulation is often much greater in amount than the coarser sands lying in the distinct dune ridges on the seaward side of the island. It is likely to shallow the lagoon waters until they are completely closed, and become converted into a strip of lowland which slowly widens toward the main shore. In many cases these blown sands would occlude the shallow waters of the lagoon in a complete way, were it not for a peculiar effect of the tide which we shall now consider. On cxamining the map of any lagoonbordered shore it will be perceived that these basins, though shallow, are often very extensive in a horizontal direction, and they are always receiving a considerable share of water from the land. Thus it comes about that where the sand reef encloses a great extent of shore, the lagoons become overfilled with the land waters and break away through to the sea. This opening is apt to be scoured out to a considerable depth by the energy with which the imprisoned waters discharge through the easily eroded material.

As soon as a channel is cut through the sand barriers it naturally becomes a way through which the ticlal waters ebb and flow. Where, as is often the case, the lagoon area accessible to the tide is of great extent, the volume of water which four times a day passes through the inlet may be so large as to develop a channel having a wirlth of several miles. To a considerable extent this tidal $\mathrm{cbb}$ and flow serves to scour out not only the passage of the inlet but a number of channels. 


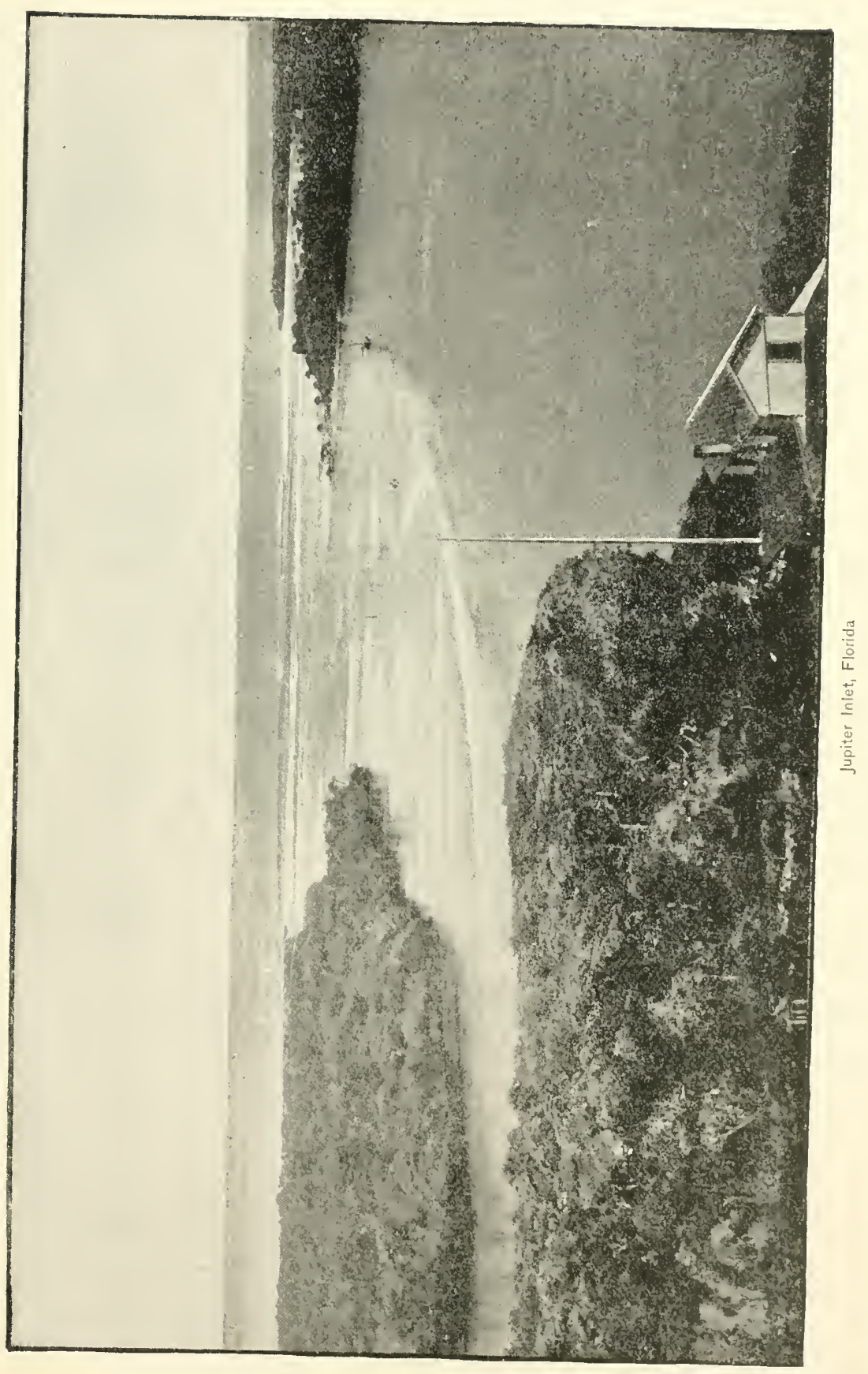



branching in the manner of a river, which often extend many miles beyond the entrance. The principal of these occupy a position between the mouths of the main rivers which enter the lagoon and the passage through the barrier reef, but others lie parallel to the shore to the point where the tidal flow, which enters from a neighboring passage, produces a field of waters in which there is practically no current. At these nodal points or positions of no current the accumulation of sand blowing across the island from the sea beach, togrether with such vegetation as can inhabit the brackish water and by its decay serve to fill the inlet, is likely to produce a low barrier or isthmus uniting the neighboring islands and the mainland. Such a barrier between adjacent inlets is commonly known by the name of "haulover," a term clerived from the fact that small vessels are often dragged across it.

Where the lagroon is narrow and shallow these isthmuses or "haulovers" are likely to be developed between the principal inlets. Where, however, the lagoon is large and fairly. deep, certain peculiar accidents are apt to keep united a great stretch of the enclosed waters communicating with the sea by several inlets. The formation of the isthmuses is mainly prevented by the action of winds which occasionally produce currents of sufficient strength in the relatively shallow water of the lagoon to scour away the dibris whenever it tends to accumulate. Noreover, as will shortly be explained, these inlets of the sand reef tend to become closed so that the floods from a particular river are compelled from time to time to make journeys in diverse directions in order to find an open channel by which they may escape to the sea. Thus in the longest connected lagoon of the American coast-that on the eastern shore of Florida known as the Indian River-each 
inlet, for the reason that the sands of the island beaches are constantly moving southward, gradually travels in a southerly direction until it abuts agrainst some obstacle. Then the further incursion of sand from the north closes the opening. At some later time, when the streams flowing into this part of the lagoon are in the state of flood, and the wind is blowing in a direction to heap up the waters, the closed channel will be replaced by a new opening, which in turn proceeds to travel southward like its predecessor, until in due process of time it also is closed. Thus by watching the direction in which these migrating inlets journey we can ascertain the average direction in which the sands are impelled along the shore.

Where an inlet remains for a considerable time in one position, the débris which passes through it toward the sea accumulates in the form of an extensive platform on the seaward side of the opening. Through this submerged, outwardcurving, delta-like accumulation the currents make tortuous channels, generally two or more in number and containing no great depth of water even at high tide. The formation of this curious platform is due in part to the effect of the current in arresting the coastwise march of the sands, and in part to the force of the stream which sets outwardly through the opening. The strength of the outward-setting current is always stronger than the influx, by the proportion which the excurrent river waters bear to the tide which passes through the inlet twice each day. As soon as the inlet has shifted its position or become closed, the waves and currents proceed to break up this peculiar delta formation and distribute its component sands in an even manner over the neighboring sea bottom. By a simple inspection of the soundings on the Coast Survey 


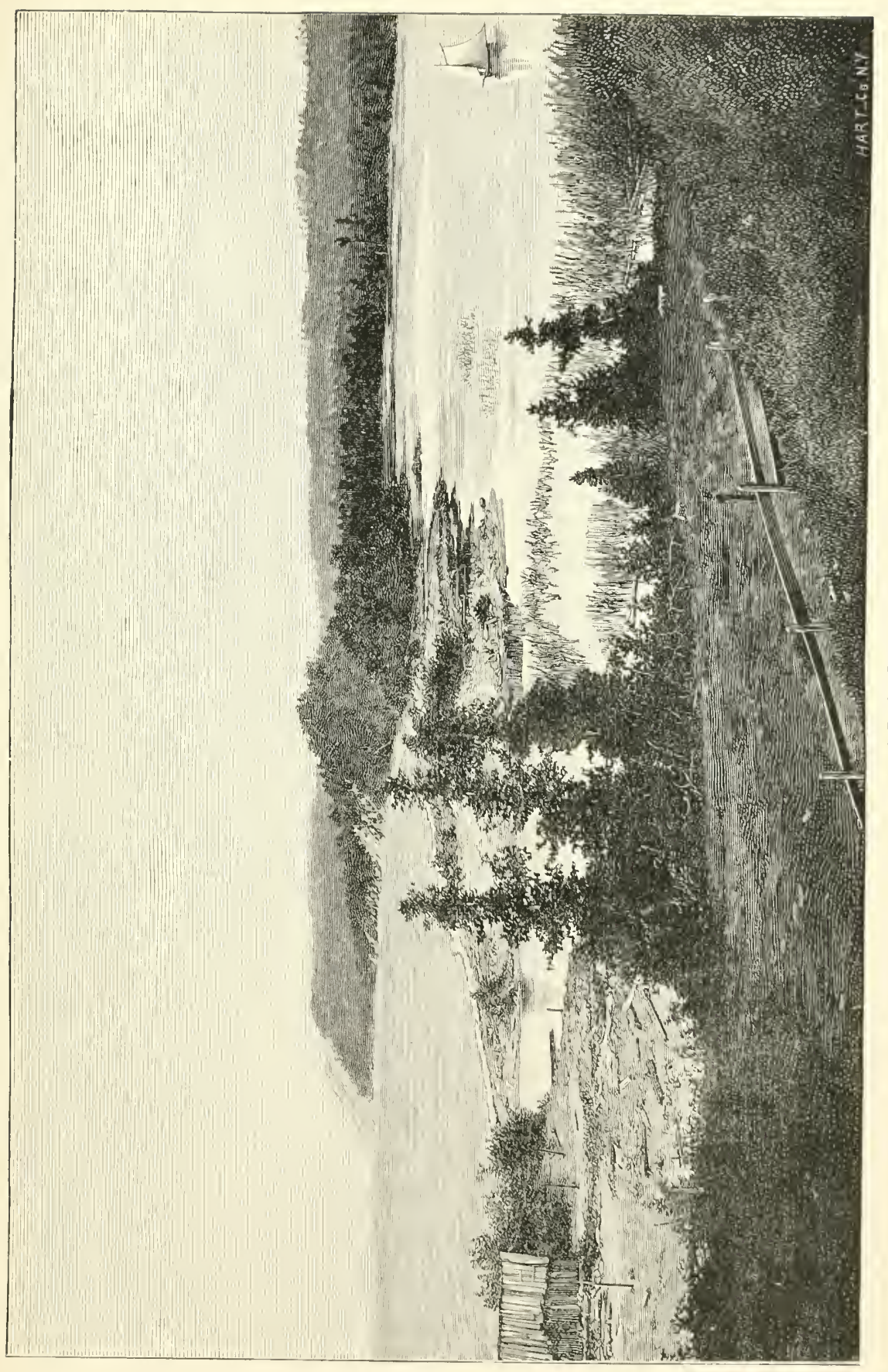



maps it is possible to determine in a tolerably accurate way by the extent of this inlet delta how long the particular entrance to the lagroon has remained open.

Where a shore-line is now in process of subsidence, as appears to be the case along the Atlantic coast from Cape Florida to New York, the depth of water in the channels

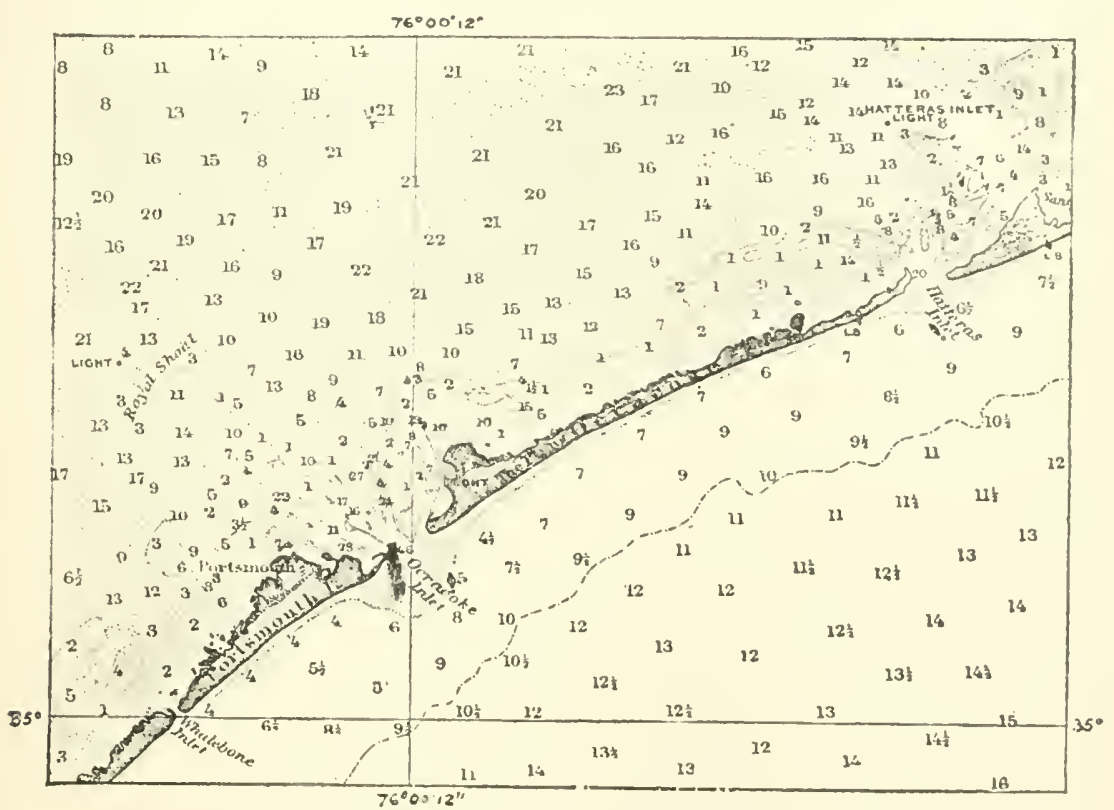

Tidal Deltas at Ocracoke and Hatteras Inlets

which lead from the inner side of the inlet to the mouths of the principal rivers is often sufficient to accommodate the largest ships. Unfortunately, however, these down-sunken and therefore deep channels are often separated from the sea by the broad and shifting barrier of sands in which the inlet lies, and which stretch for some distance beyond its seaward mouth. Owing to the unstable character of the sands which constitute this barrier, and the constant movement of dibris 
along the shores, it is very difficult to secure any permanent increase in depth of water by any application of engineering skill.

A century ago, when trading ships had less than half their present tonnage, rarely drawing more than fifteen feet of water, lagoon harbors were excellently suited to the needs of commerce; but at the present time, when many vessels trading with foreign countries have a clraft of twenty feet or more, such ports have become less useful, and have to be bettered by engineering appliances or they are likely to pass out of use except by relatively small coasting vessels. As the greater part of the harbors between Norfolk and the Rio Grancle are of the lagoon type, the question as to the improvability of these ports is clearly of very great importance.

The group of embayments which we have to consider under the head of sand-spit harbors, are, as regards their origin and nature, closely related to the lagoon harbors last described. They have, however, sufficient individual character to deserve mention under a separate head. Sand spits are formed where the beach materials of a shore are forced by the prevailing direction of the waves or currents to travel in a more or less continuous manner in a particular direction along the coast. Except for careful observations, this movement may not be detected until the materials attain a point where there is a more or less definite bay extending into the mainland. At such a point the sands, instead of flowing back into the reëntrant, may be built out in the form of a long spit which grows steadfastly at its outer end until it may project more or less completely across the mouth of the opening. Excellent examples of these spit beaches are traceable along our American shore from northern Massachusetts to Mexico. 


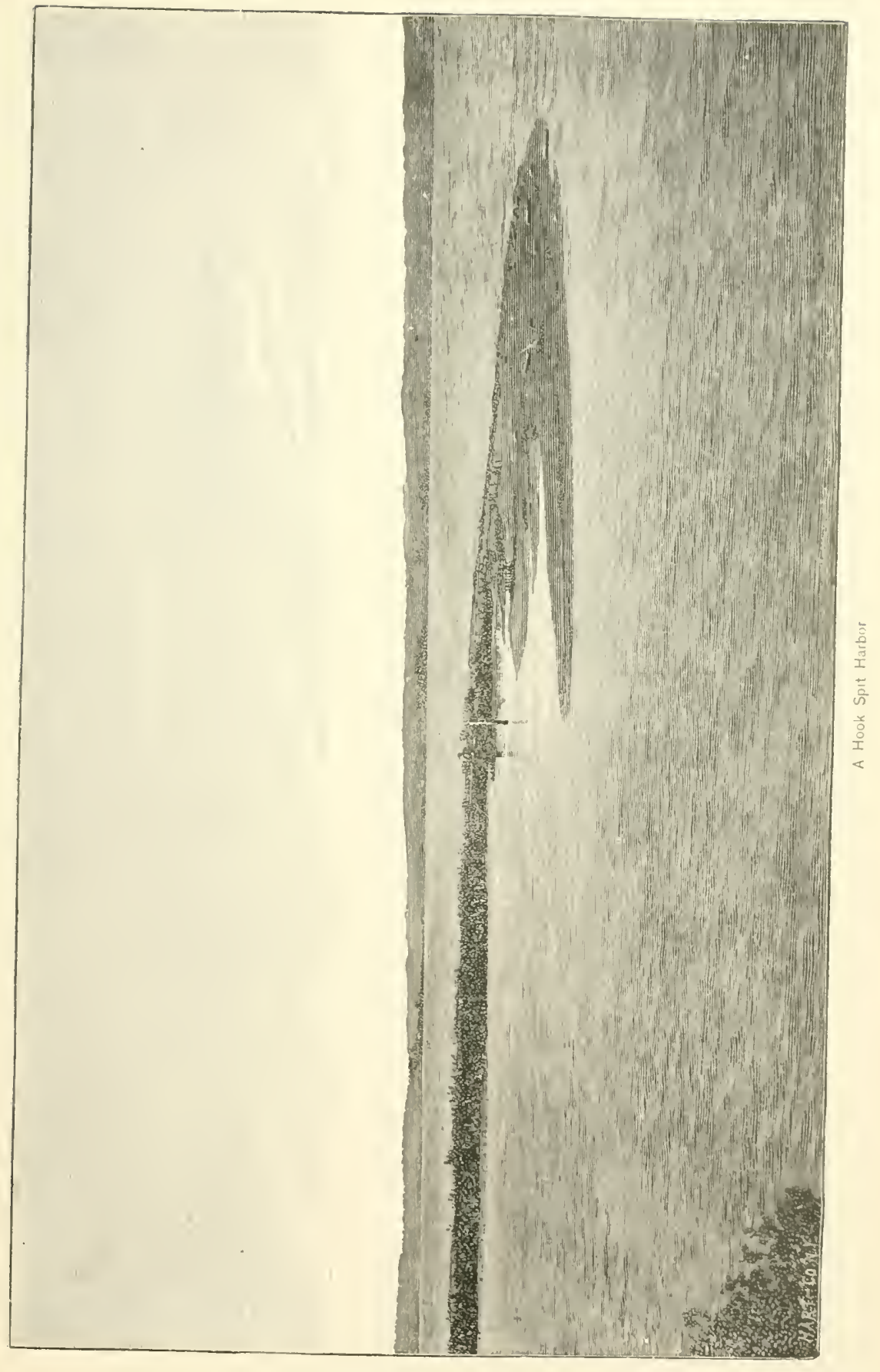



Ordinarily the projections are straight, but where in the course of their growth their extremities come in contact with strong currents, they may be turned so as to make hooks of remarkably curved or angular outline, occasionally cnclosing considerable sheets of water of sufficient lepth to have value for harborage purposes. Provincetown Harbor, on Cape Cod, is an example of this nature. That at Cape Pogue, on Martha's Vineyard, though the embayed waters are very shallow and have no value for purposes of shelter, is, as an illustration of the process by which these hooks are formed, one of the most interesting structures belonging in the group.

The directions in which sands journey along the shore, as well as the speed of their movement, depends mainly on the attitude of the coast-line in relation to the prevailing winds and currents. These effects may be traced, not only in a local way, but sometimes throughout a far-reaching extent of shores. Thus on the Atlantic coast from Chesapeake Bay to Cape Florida, the prevailing course of the sand is to the southward. The beaches have been characterized by a movement in that direction since they first came to be observed. To this endless procession of sands is due the southward march of the ever-changing inlets in the manner indicated in the description of lagoon harbors. This movement of sands toward the south along the Atlantic shore is clue, in part at least, to the fact that while that coast-line extends in a general northeast and southwest direction, the prevailing winds and the waves which they produce are from the points between cast and north, so that the surges strike the coast at an oblique angle and tend to urge the detritus toward the southern part of Florida. At the cape of that name we find the southern extremity at which these marching sands have as 
yet attained in their movement between high-tide and lowtide mark. At this extreme southern position the quantity of the sand is not great, and the grains of silex of which it is composed are much rounded by their long and arduous journey, at every step of which they have been beaten by the waves. It appears likely that in time these wandering sands will attain to the extreme southern part of Florida, destroying or diminishing the coral-producing polyps as they go. Probably to their action is clue, in part at least, the diminution of the reef, which is but feebly exhibited in the district to which this detritus has attained.

Although sand-spit harbors or equivalent structures composed of gravel or shingle of themselves form few important havens, they are a concomitant feature in the natural defences of many ports. They are often conspicuous at the mouths of reëntrant delta harbors, and serve to protect that class of ports from the incursion of the waves to which their naturally broad mouths ordinarily exposed them. This effect may be clearly seen at the mouth of Mobile Bay, Galveston Bay, and various other points on the Atlantic coast. Not only do these spits afford protection from the ocean's surges, but they often serve to deepen the channels which give access to the port, and thereby to render the harbor accessible to larger vessels. Where they do not exist it is often necessary to accomplish the work which they might do, by means of artificial construction. We may furthermore note the fact that when once formed these spits tend to prevent the entrance into a bay of the sands which the waves scour from the shallowed bottom over which they roll, and which, but for the presence of these barriers, might penetrate far enough into the harbor seriously to reduce the depth of water. Thus the 
first stages of a sand spit's formation are often advantageous to the haven at the mouth of which they form. In the course of time, however, as the drifting sands accumulate, they force the entrance to the port to the side toward which they are travelling, and as they cannot readily pass the tideway channel provided the stream be vigorous, they accumulate on either side of its mouth in broad shallows, such as are described as lying in front of the passages which lead through the lagoon barriers to the sea.

In tideless seas or large fresh-water lakes these spits are perhaps the most serious menaces to the harbors. Owing to the weakness or absence of currents to break through the barriers which they form, they are apt to wall across the inlet, leaving no larger channel than suffices to discharge the waters of the rivers which enter the embayment. A comparison of the spit harbors in our great lakes or other non-tidal basins shows how important are these alternating currents for the preservation, and often also for the construction, of havens. Along shores of such seas and lakes the spits are not so neatly formed as on the open sea-shore. A large part of the migrating sand is sure to enter the currentless harbor and shoal its waters.

The group of volcanic crater havens will be mentioned only in order to complete the list of the causes by which harbors fit to shelter ships are formed. It is a familiar fact that volcanic craters commonly have a cup-shaped form, and in most instances the rim which surrounds the central carity is broken down at one or more places by the outrush of lava or by the ruptures which are naturally formed during the throes of an explosion. It is also a well-known fact that by far the greater part of the well-preserved craters of the 
world lie along the coast-lines of the continents or upon the islands which border the shores of the mainland and are scattered orer the wide seis. On account of their position with reference to the ocean level, it not infrequently occurs that the sea enters an inactive crater through a relatively narrow breach and forms a large and well-sheltered basin in the middle of the cone. If such havens occurred in convenient positions

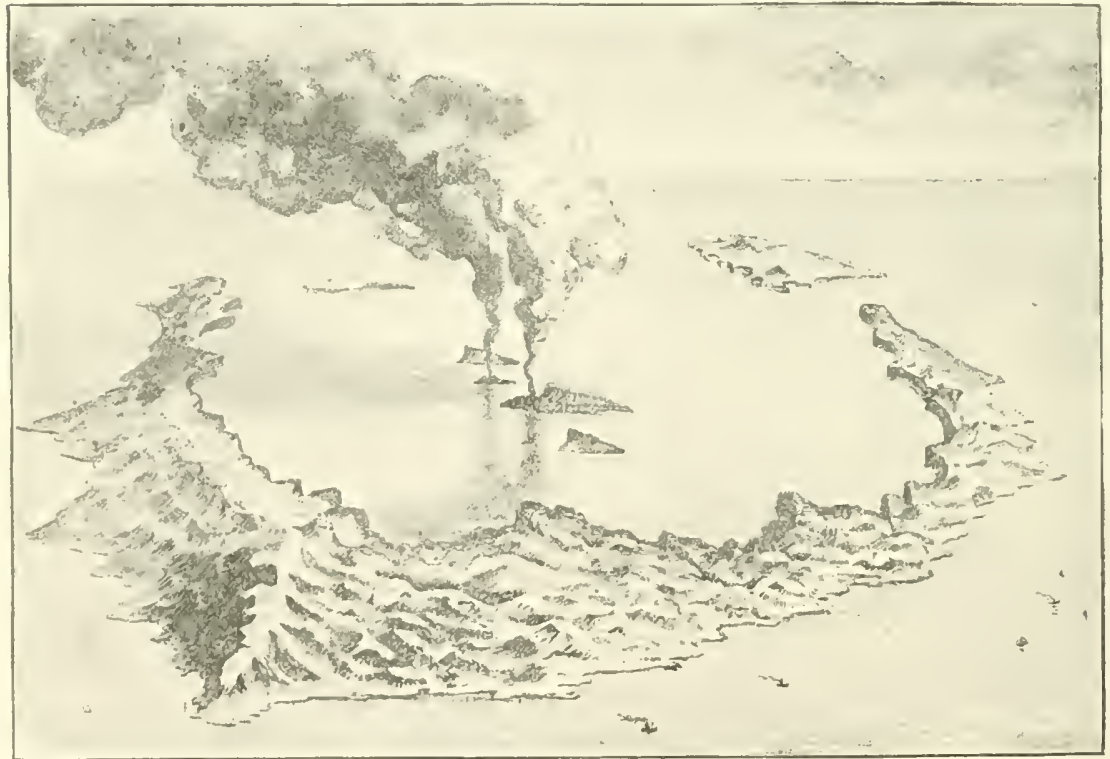

Volcanic Harbor

for commerce and if their bottoms afforded good anchorage grounds, they might have great economic value; but occurring, as they almost invariably do, on small and desolate islands, they have no other than a scientific interest. They may be compared to the interesting lakes which frequently form in the cups of long-inactive volcanoes, such as those found in the region north and south of Rome, which are very striking and beautiful features in the landscape, but 
interesting only on account of these qualities. So far as the present writer is aware, no settlement deserving the name of a port exists on the shores of a crater harbor, though there are sundry of these peculiar havens in the eastern Mediterranean and the East Indies which are occasionally used as shelters by ships.

The harbors which are produced by the resf-building corals, together with the various marine animals and plants which are associated with them, are among the most interesting and important of all classes of havens. They are not only in origin the most peculiar of all inlets of the sea, but the conditions of their development and the circumstances which lead to their preservation and destruction are also curious and noteworthy. Noreover, in the district of southern Florida organic recfs of this nature are numerous and extensive, and the ports which they form, though as yet relatively little used, are destined in course of time to have great value to this country.

Coral-reef harbors may be divided into two classes, determined by the physical character of the reefs which lead to their formation. The structures belonging to these distinct groups are barrier reefs, and circular or elliptical formations of the same nature, commonly known as atolls. As the history of these two groups of reefs is essentially that of the harbors which they form, we must brietly trace in outline the methods and conditions of their growth. The growth of all coral reefs depends upon certain polyps which secrete a limestone support for their bodies, having the organic habit of growing together in closely associated communities which unite their limestone framework so as to form rock-like masses. These creatures add to the number 
in their several societies by a process of budding, while they multiply the communities themselves by reproduction from the egs. Thus they are able to grow continuously. after the manner of forest trees, the living resting upon the framework which the dead have left behind then. By means of this double growth they are able to construct vast limestone ridges wherever the conditions of the sea favor their development.

Although solitary corals and communities of insignificant growth plentifully develop far and wide over the sea-floors of tropical and even of temperate regions, the reef-building species can do their characteristic work of construction only where tolerably swift moving currents of pure water, having the temperature of the tropical seas, flow against shores or shallows where the water is less than about a hundred and twenty feet in depth. Where such oceanic currents impinge upon a shore or shallow, the germs of the reef-building corals develop upon the bottom, spread over the surface which has less than twenty fathoms of water upon it, and proceed to grow with great rapiclity. The evidence goes to show that some of the species may rise above the bottom, at the rate of as much as three inches a year, and it is not improbable that these reefs may grow upward, if the conditions be favorable for rapid growth, to the extent of a foot in from one hundred to two hundred years. This, though slow in terms of human history, is in a geologic sense extremely rapid. As the reef gains in thickness, the outer part of the growth, that which faces the deeper sea, waxes more rapidly, for the colonies of polyps which occupy that position are most effectively bathed by the ocean currents from the waters of which the animals take their food. The nearer this swiftly growing margin 
comes to the surface of the water, the more effectively it debars the polyps on the interior of the reef from the visitation of the nourishing streams flowing inward from the sea. 'The result is that when a reef has attained to about the level of low tide, which is the limit of its growth, there is generally an unfilled channel occupied by a lagoon-like expanse of waters on its inside, the basin communicating with the sea by various passages or breaks in the line of the reef.

Where such a coral reef is formed against the shore of a mainland or island, the reef usually extends in a direction generally parallel to the coast for the distance through which the ocean currents exercise their effect on the development and growth of the polyps. Thus along the coast of Florida the Gulf Stream has favored the formation of these reefs, from the shoals at the southern and western extremity of the peninsula to a point a score or two of miles north of Cape Florida. As far north as Biscayne Passage at the abovementioned cape, the reef, except for the occasional open channels, rises to near low-tide mark. North of that point, owing perhaps to the coolness of the water, as well as to the southward movement of sands above described, the reef is stunted, its summit does not rise to the level of the sea, and the whole structure gradually fades away.

As soon as the outer part of a coral reef has risen to near the surface of the water, the sea in times of storm breaks upon the barrier, so that the lagoon between the rim of the reef and the mainland may afford excellent shelter for ships. If the coast be long and straight the enclosed channel may be open to the rake of the winds in certain directions, but in general at points between the site of the channels through the 
reef various accumulations of organic waste shoal the water or construct spits across it so that the lagoon, much after the manner of those enclosed by sand reefs, as above described, becomes divided into sections of no very great extent. It occasionally happens, as in the case of a great reef off the eastern coast of Australia, that the wall is very far from the land, so that the lagoon area, being very wide, has little value as a harbor.

A large part of the coral matter which is developed on the front of the reef is broken off in times of heavy storms and ground to powder in the surf. A portion of this waste is tossed over the reef or clrifts in through the inlets, and is thus added to the sediments accumulating on the bottom of the lagoon. Another portion of the débris is dragged seaward by the undertow and distributed in front of the reef. In this way the seafloor next the barrier is gradually shallowed. When in the course of this process it is elevated to the level where the water is only a little more than a hundred feet deep, a new coral reef may begin to form which will in time rise to such a height as to deprive the older barrier of its due share of food-giving water. When this condition comes about the old reef dies, and the frail materials of which it is composed may to a certain extent, at least in the upper part of the structure, become broken up by the waves or dissolved by their waters so that the once marked ridge may lose its distinct character. In certain cases, where the sea waters are not saturated with limy matter, they may take into solution and bear away to other regions a part of the material which is afforded by the clead coral and other organic remains in the section within the growing reef. It is perhaps to this solvent action that we owe, in part at least, the sometimes remarkably deep channels which penetrate 
through the reef and extend for some listance across the floor of the lagoon.

While along the coasts of the mainlands and greater islands where coral reefs occur they commonly appear in the general form of broad shelves with the rim of higher and living reef next the sea and a prevailing shallow lagoon or channel between this barrier and the shore, their form is sometimes much affected by the upward and downward movement of the shore-land district against which they lie. An elevation such as frequently occurs and has lately happened along the coast of Floricla may bring the reef and the lagoon as well above the level of the sea; in some cases successive elevations have thus cleveloped a considerable breadth of shore country composed of reef deposits. Through these easily dissolved rocks the river waters may carve, mainly by their dissolving action, tolerably deep channels which may serve as harborages. In other cases the subsidence of the coast may lower the barrier reef more rapidly than the coral animals can effect its elevation, and in this way the ridge which at one time sheltered the coast from the waves may no longer afford such protection.

The group of atolls or annular reefs is imperfectly represented in the Atlantic district, but attains a remarkable development in the Pacific and Indian Oceans. In their characteristic forms these wonderful islands consist of a steeply sloping obscurely conical elevation rising from the floor of the sea, which often exceeds a mile in profundity. to the surface of the water. Above the sea level there is a more or less complete ridge composed of decayed and broken-up coral which has been swept into position somewhat inside of the living reef by the action of the waves. The central parts of the island are occupied by a shallow basin of water which in 
almost all cases communicates with the open sea by one or more channels. If the waters of the Pacific and Indian Oceans in the districts occupied by these atolls could be drained away, the cbserver would often be able to journey for many hundred miles through fields occupied by towering mountain-like elevations, each rising with steep and regular slopes to a certain level, and nearly all of them containing a shallow, cup-shaped carity on the summits. In some cases these mountains would be in figure very nearly true cones, but by far the larger number of them have elongated forms. Here and there in the Pacific Ocean where the sea-floor has been subject to recent elevation, these atolls have been lifted until their summits are some hundreds of feet above the plane of the sea. So far as has been observed, these highlying coral islands have lost their characteristic cup-shaped summits by the process of erosion.

There is much clebate at present as to the origin of these interesting atolls. Until recently the explanation adduced by Charles Darwin found universal acceptance. This was in effect that the coral reefs began to grow in the form of a barrier surrounding some island of ordinary rock such as is often formed in the sea by a partially submerged mountain peak or a volcanic cone. The sea-floor on which the clevation rested being in process of gradual subsidence, but at a rate not sufficient to destroy the corals of the reefs, the living rock gradually built upward until when the original land disappeared beneath the waters nothing was left to mark its former site except the limestone deposits formed by the zoöphytes and other animals which continued to develop upon its submerged summit. One of the proofs of this hypothesis was found in the occasional cases where ordinary islands 
present a more or less complete ring of reefs about their shores. In case such an island should gradually sink, the result would necessarily be the creation of an atoll.

Lately Dr. Miurray and others have contended for the view which explains the formation of an atoll on the supposition that a coral bank forms at any point on the sea-floor where the depth of water is not too great and where there is a continuous marine current of sufficient temperature to maintain the growth of the reef-building species. The cavity or lagroon within the reef is explained by the solvent action of the water, which tencls to take up and to bear away the limy material with which it comes in contact. It seems not improbable that these islands with cup-shaped centres may be produced in the ways indicated by hoth these hypotheses. That advanced by Dr. Murray, hoirever, seems to be the simplest and most rational explanation of the facts.

From the point of view of the student of harbors it is only necessary to remark that, owing to the small amouni of fertile soil which the narrow sirip of land enclosing the atoll lagoon affords, these havens can never have much commercial importance. 'I hey serve as shelters for a few small trading ships, and they may in time be prized by yachtsmen; but they can never have much relation to commerce. Though much more striking and beautiful features than the barrier reefs, they are of very much less economic value. Probably far more ships have been cast away upon these coral reefs of mid-ocean than have been protected from storms in the beautiful but generally inaccessible havens which they afford. Thus as a whole we must look to the barrier reefs as affording the only really important harbors which are produced through 
the agency of organic life. Although in the realm of the tropics there are innumerable ports which owe their origin to this last-named class of reefs, none of them have as yet any great commercial importance. They at present serve mainly for small vessels. They can in general only be made useful to our modern marine by a continuous and expensive process of dredging, to make head against the rapid growth of the zoöphyte communities and the accumulations of sediments brought about by the intensely vigorous organic life which develops within the coral reefs.

The port of Hamilton on the Bermudas is perhaps the best instance of an important haven situated on a coral reef belonging to the class of atolls, while the beautiful Biscayne Bay on the east coast of Florida is an excellent example of a haven which is enclosed by barrier reefs.

In the foregoing summary account the several classes of natural actions which lead to the formation of harbors have been considered. We have now to take into account the other modes of operation of the geologic forces which tend to alter for better or for worse the physical conditions of our havens in determining the ease with which they may be approached, the character of their shores, and the depth of water which they afford. All these changes are brought about as a result of the application of energy, operating in diverse ways along our shores. Therefore the reader will the more readily come to an understanding of the questions with which we have to deal if we begin the inquiry by noting the general nature and mode of action of these forces.

There are four modes in which energy is applied in a way to modify the conditions of coast-lines. Three of these have their origin in the celestial spaces; one only comes from 
the earth itself. The most important source of energy which is applied to the earth is the heat of the sun. This takes effect on the earth in two diverse way's. In the first place, by warming the water it lifts the vapor of that fluid into the air, whence it is precipitated in the form of rain or snow. In either of these states the part of the precipitated water which falls upon the land moves back toward the sea in the form of rivers or glaciers, bearing with it a share of the earthy or rocky matter with which it comes in contact. This abraded material is in large part deposited next the coastline; the principal portion of it, indeed, finds its way to the bottom either within or at the mouth of the natural harbors of our shores. The solar heat also operates in another way, by which it does yet more effective work upon the coast-line. Owing to the differences of temperature which it induces, and the variations in weight of the atmosphere dependent on those variations of heat, the radiation from the sun brings about the movement of the winds. Where these sweep over water surfaces they create waves of a magnitude proportional to the width and somewhat to the depth of the water basin which is traversed, and to the continuity and energy of the air movement. Where these waves roll against the shore they apply the energy which they have received from the wind in rasping the bottom of the shallow water and in beating against the coast-line.

The two modes of geologic action just adverted to are due to solar heat, and, though widely different in their manner of operation, they have a like origin. The third mode of action which we have to consider is that which arises from the gravitative impulse exercised upon the earth by the nearer and larger celestial bodies, the moon and the sun. While 
all the orbs of space exercise a measure of attraction on our own sphere, the moon and sun, owing to nearness and mass respectively, are the only bodies which effect a recognizable influence upon its surface. These two bodies pull so strongly upon this planet that in the widest and deepest ocean they form two tidal waves opposite each other, each some thousands of miles wide and a foot or two in height. If the whole surface of the earth were occupied by the sea waters everywhere to the depth of four miles, say, the maximum height of the tide would probably be about a foot. Although this tide would move around the earth beneath the equator with the speed of a thousand miles an hour, it could exercise no considerable effect on the conditions of the sphere, for, according to the supposition, it would meet no shores or shallows; the whole consequences of the tidal movement would be the application of a slight friction to the bottom, which, being applied against the direction of the earth's rotation, would tend very slowly to overcome the momentum with which this sphere turns upon its axis.

In the existing condition of the earth the lunar and solar tides. though of slight altitude in the wider parts of the great southern sea and Pacific Ocean, become wedged in between the converging shores of the lesser water basins in such a manner that the water may be lifted in each ticlal interval to much sreater heights. V'ery commonly this increase in altitude amounts to ten or twelve feet, and in exceptional cases to fifty feet or more. As the energy which a tidal wave applies to a coast-line is in a general way proportional to the rise and fall of the undulation, it is easy to see that the share of this impulse derived from the attraction of the sun and moon, exerted on different parts of the shore, is exceedingly 
varied. In fresh-water lakes and lesser seas the tidal ware is not developed at all. In greater basins such as the Mediterranean the undulations are so slight that their influence is scarcely perceptible; but about the head of such ocranic reëntrants as the North Atlantic, where the wave rolling in from the south is compressed between converging shores, a vast amount of tidal work is clone.

The fourth group of actions effective on sea-shores is derived from the movements of subsidence, elevation, and sudden jarring which may take place on the sea-floor. Some of the most important alterations of our harbors are effected by the uprising or downsinking of the portions of the earth near which they are situated. Movements of this sort, if they take place over very extensive portions of the oceanfloor, may, by displacing the water of all the oceans and open seas, lead to changes in the depth of water in harborages all over the world. Thus, if, as seems probable, an area of several million square miles in the central district of the Pacific Ocean is undergoing subsidence at the present time. the influence of the movement, long continued and extensive. may be felt in all marine ports. In general, however, local accidents in the way of subsidence and elevation are so considerable as to make these wide-spread oscillations of the ocean-floor relatively unimportant.

Besides the long-continued oscillations of level of shore land and sea bottom, an effect is exercised upon the coastline through the sudden movements of the earth beneath the seas, due to earthquake shocks. These seismic jarrings. create an elevation of the water over the shaken surface, which is in its nature a broad wave, having, it may be, an altitude of several feet, and which may roll across the 
wide oceans and break upon their shores with calamitous effects.

With this preliminary statement as to the nature and origin of the classes of energy which operate on a coast-line we shall now proceed to consider somewhat in detail the effects produced by these causes in increasing or diminishing the value of our havens. First among them we have to note the effect of the sediment brought into harbors by the rivers.

The waste of the land which is brought down to the shore by the rivers is conveyed in two different forms: in part as completely dissolved sediment, which does not discolor the water; and in part as materials which are visible to the eye as mud, rendering the water turbid, or grains of sand or small pebbles rolled on the bottom, or at most carried a little distance above it. As long as the water of the river is held within distinct banks, the energy of its flow to a great extent prevents the mud from sinking to the bottom and the sand and pebbles from coming to rest, so that the channel may remain substantially unchanged as regards its position or the depth of the stream. At the outlet, however, where the river's tide is discharged into an open basin, the current is soon arrested, and gravitation is free to act on all the mud it conveys. Only the completely dissolved materials, such as salt, lime and various other substances, are free to journey onward for indefinite distances in the ocean currents.

Where the river discharges into a lake of fresh water the suspended materials, at least the finer portions, find their way' to the bottom much more slowly than where they enter a saltwater basin, because the saline matter of the sea water has a peculiar effect in hastening the precipitation of mud. In any case, however, it rarely occurs that the river mud journeys 
more than a few score miles from the point where it enters any large water basin. In the greater streams the quantity of this detritus which is carried to the sea is often very great. Thus the Mississippi sends out each year somewhere near onetwentieth of a cubic mile of undissolved material, the whole of which doubtless comes to rest on the broad margin of the growing delta; and the Imazon, owing to the greater rainfall of its basin, probably contributes several times as much sediment to the sea-floors near its mouth. 'The result of this effusion of sediment into the basin near the mouth is that all rivers which pour forth turbid waters are apt to have wide shallows without very distinct channels at their points of exit. Where, as in the case of the Amazon, the entrance to the delta mouth is not thus obstructed, a condition which rarely occurs, we have to account for the fact either by a recent subsidence of the land or through the action of powerful currents such as are produced by tides, coöperating, it may be, with oceanic movements brought about in other ways.

Wherever a stream conveying a considerable amount of detritus enters any bay or other indentation of the coast, we fund indication of its clamaging action upon the harborage. Beginning at the head of the recintrant it constructs a deltalike accumulation, which gradually converts the basin into marshy land. In front of the distinct delta there is a wide. gently sloping surface over which the finer mud is laid clown. If a part of the dibris escapes from beyond the harbor mouth the currents and waves of the shore, acting in a manner hereafter to be clescribed, are apt to build the accumulation into the form of bars or spits which may more or less close the entrance to the port. In this way some of our more important havens, such as that of Mobile Bay, are subjected to a constant 
depreciation. So far no successful means have been discovered whereby the effect arising from this constant importation of sediments into a harbor may be arrested. The only recourse seems to be dredging - a slow and costly process, by which the deposits of mud are removed from the important channels and conveyed by boat to some point where they will not return to the basin.

It is fortunate that, though our bays and other harborage places are generally entered by rivers, only a few of these shelters suffer any rapid depreciation by the action of the streams. Moreover, in the case of very many of our rivers of this continent, as well as those of northern Europe, there are certain conditions which fortunately limit the amount of detritus which the flowing water brings down to the sea level. Because they lie in glaciated districts the streams of the northern lands generally drain from regions which are deeply covered with sandy and pebbly waste. In such cases the greater part of the rain-water passes into the porous drift material, and is only gradually yielded to the streams. Thus the river system of a glaciated district has in proportion to the outflow very few torrents, such as characterize the surface of regions not underlaid by glacial waste. It is the swiftmoving currents of these torrents which do almost all the work of breaking up rocky matter into the shape in which it may be transported as mud by the largest streams.

Almost all the considerable rivers of glaciated districts pass through lakes, where their waters are for a time brought to a state of almost complete rest and are thus led to lay down their burden of sediment before they flow on to the sea. An excellent instance of this is found in the case of the St. Lawrence, which has a chain of great lakes in its main path, in 
addition to which all the important tributaries that enter its channel below the mouth of I ake Ontario pass throngh smaller but sufficient natural catch-pools, that retain the débris. The result is that the vast tide of the St. Lawrence waters comes to the sea level almost without burden of sediment, and nothing like a delta deposit appears at the mouth of the stream.

Owing to certain peculiarities in their conditions, the large rivers which flow into the Arctic Ocean. the Mackenzie of North America, and the Lena, the Obi and the Yenisei of Asia, discharge much larger amounts of sediment than any other streams of high latitudes. The cause of this is peculiar. In the winter season the ice forms in the lower and more northern portion of these streams to such thickness that they are often frozen to their very bottoms, so that when the spring floods send down a great tide of water from the southern tributaries the current is unable to break up the ice which fills the accustomed channel of the river, and the inundations sweep far and wide on either side of their fit path. In these movements they erode a great deal of earthy matter and bear it to the mouth of the streams. The result is that the mud cleposits in the delta districts about the Arctic Ocean are much more extensive than in other parts of the northern realm, but as the harborages of this sea-shore have no commercial value the effect of these mud accumulations is of no economic importance.

If the sea-shore maintains this position for any considerable geologic time, the effect of river action would be to make the mouth of every stream discharging into the ocean the seat of a delta, and as almost all our ports have tributary rivers, the number of harbors, except such as the clelta channels afford, would 
be very few. As it is, there are only a few score of conspicuous deltas in the world, and the limitation in the number is clearly to be explained by the frequent oscillations of the shoreline.

The mode of action of the solar heat which is brought about by the intervention of waves has a more wide-spread effect on the conclitions of harbors, and on the whole a more important one, than that which is induced by the transportation and deposition of river-borne detritus. Every coast-line, even if it be only that of an inconsiderable lake, is sure to be affected by wave action. Every cliff shore is a natural factory for the production of detritus. This material is composed of small disconnected bits, which are readily moved by the waves and currents. The heavier waves can swing masses each of which weighs many tons; the undulations of less size can move fragments proportionate to their energy; and even the wavelets which, when they break, have a height of no more than a foot, can toss bits of rock as large as marbles several feet to and fro in each oscillation. Not only does the déris produced by wave action sway to and fro up and down the beach in the oscillating movement of the water, but it is in all cases liable to be carried along the coast by wave action either directly through their stroke or secondarily by the currents which they induce. If the wave rolls in against the shore at right angles to its trend, the movable dibris on the beach merely rolls up and down the slope without changring its position in any important way. If, however, as is oftenest the case, the waves strike at a more or less considerable angle to the shore, the fragments as they move to and fro work along the coast in the direction in which the waves are. trencling.

Besides the motion imparted to the debris of the sea-coast by 


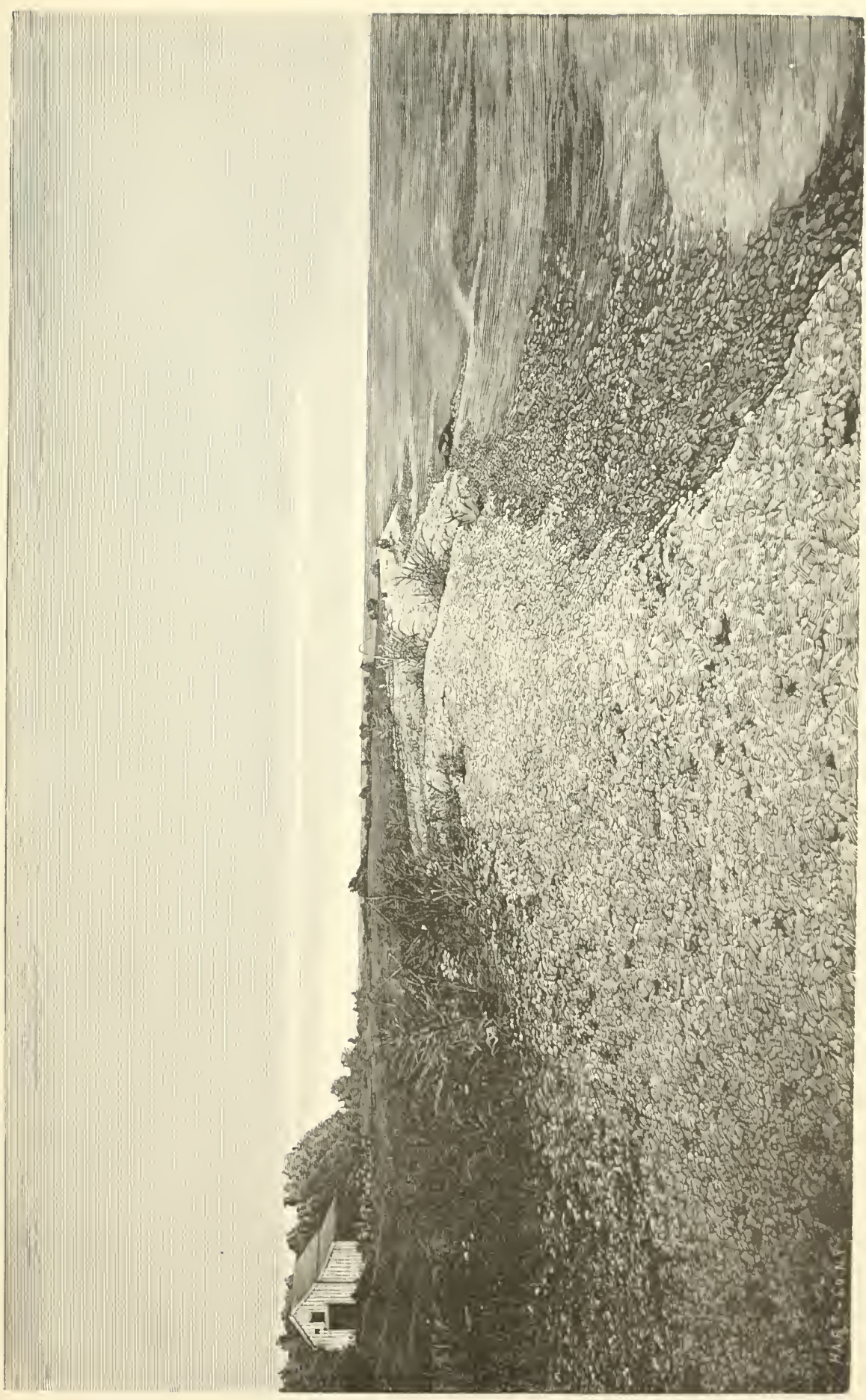



the direct action of the waves we have to take account of the movement effected by the currents which the winds produce along a shore. Such wind-induced streams, more or less reënforced by tidal movements, often flow with a speed of ordinary rivers, and are equally effective in conveying detritus. The action of these varying currents can often be noticed in cases of shipwreck, when the dibris from the castaway vessel is in the course of a few hours scattered along many miles of shore which lies leeward of the point where the disaster occurred. The effect of these currents is to transport the detritus which the waves grind up along the shore until the drifting material attains a point where it may enter some recess which is so deeply embayed that no change in the direction of the wind can cause it to be removed by wave action. As this indentation of the coast-line is apt to be a natural harbor, the effect of the coastwise movement of detritus is often in high measure destructive to the usefulness of ports.

The damage done by wandering sands is greatest where there is no tidal action, as along the shores of the larger lakes and lesser seas. Along such coasts as are not tide-swept, the wave- and current-borne detritus rapidly finds its way into all the recesses. In course of time the waters of the embayments become so far shallowed as to be unserviceable to ships. The effect of this action is conspicuous on the shores of our great lakes of North America, particularly those which lie in the valley of the St. Lawrence River. Although the present shoreline of these lakes has been where it now is for but a short geologic time, so that the harborages are relatively very new, the influence of migrating sands has been already effective in closing many originally good ports. The damage done in this way is most conspicuous in the lower lakes of this series. In 
Lake Superior less injury has been effected by the coastwise wandering detritus, for the reason that the shore is more rocky than that of the other basins, and as yet the platform at the base of the cliffs has not been sufficiently developed to make as continuous beaches as we find along the coasts of Lakes Michigan, Erie, and Ontario.

Where a coast-line has an irregular front which is bordered by distinct salient capes or fringed with islands, the coastwise migration of sediments under the influence of waves and currents is much less continuous and therefore less menacing to harbors than where the shore is characterized by long, straight line beaches. On the uninterrupted shores the march of the detritus may be singularly steadfast; it may, indeed, be computed from year to year as at a certain rate. A change of wind may set the materials temporarily this way or that, but the average movement is in most cases subject to no considerable alterations in its course. Where, however, the shore-line is embayed, the recesses form pockets in which the waste accumnlates and beyond which it cannot journey until the basin is filled and the beach is extended across its front. Thus along the fiorcl zone, where embayments are very numerous, the coastwise marching of dibris is hardly to be noticed, while on the sand beaches farther southward we may trace a continuous procession of detritus, often moving straight away along the shores for scores or hundreds of miles.

Where, as is generally the case in the fiord zone, there are islands or shoals lying on either side of a considerable reëntrant, a curious action arises, which leads to the formation of pocket-beaches. Where the islands lie in the manner which favors the formation of pocket-beaches, they may prove useful elements of protection to a haven. Where, however, they are 
immediately in front of the port they are apt to yicld detritus which may be, indeed generally is, carried directly into the port by the ocean waves. In this respect they are much more dangerous than headlands, for the latter often have conditions which favor the development of pocket-beaches on one side of their faces, but all the waste worn from an island is apt to tail around either end of its mass and march straight away toward the channel of the port. Along our northern shores it not infrequently happens that insular masses of glacial drift, frequently in the form of drumlins, lie at the mouth of the haven or within it. As the drift materials of which they are composed are easily broken up, even by slight waves, and much of the matter is in the form of clay, which can be borne to great distances by currents, such shores as these isles afford are a constant menace to the neighboring harborages.

Almost all the important ports of the world have to contend against the inconveniences which arise from the immigration of detritus which wanders toward them from along the neighboring shores. One of the first tasks of the engineer who has charge of the defences of such harbors against their natural enemies, the waves, is to secure protection as far as possible by constructing walls or other revetments which may serve to keep the sea from assailing cliffs of a nature to be easily washed away. In this manner much can be effected to aid the work of the natural pocket-beaches. In other cases artificial pockets may be constructed by building moles from the shore; but while with such contrivances it is generally possible to prevent the incursion of the coarser sands and pebbles, the finer mud which sweeps along the bottom in even tolerably deep water cannot thus be debarred entrance to the harbor. 
The main protection against this evil is afforded by the tidal currents combined with the river waters which reënforce their action. In their unaided work, or with the direction which the engineer may give to their currents, the tidal movements are after all the best natural defences of a harbor. 


\section{TIDAL CURRENTS AND ORGANIC LIFE IN HARBORS}

Effects of Tirles on Ilarbors : Organization of Tidal Streams; Effect of Tidal Pars. - Action of Organic I.ife in IIarbors; Classes of Work done.-Effect of Marine Plants; Flowering Species: Sea-weeds, - Growth of Marine Marshes : their Relation to Tidal Currents; their Value for Tillage.-Tropical Marine Marshes.-Effect of Mangroves on these Areas.-Effects of Organic Life on Ilarhors: Work done by Mollunks; by the Common Oyster; Comparison of Northern and Southern Marine Mlarshes; Work done by other Animal Species.-Synopsis.

Tile effect of tides upon a shore-line is in admirable contrast to that of waves. Although both of these movements of the water are in their nature unctulations, the difference in their form leads to an entire contrast in their action. Thus wind waves strike ordinary blows; the tidal wave delivers no stroke whatever. The surges are most effective on the headlands; the friction which they encounter on the bottom causes them rapidly to diminish in size as they pass in between the converging shores of an embayment. On the other hand the ticlal wave, because of its breadth from front to rear, heaps up in a bay in a very remarkable manner. It may often happen that a recess of the shore having a length of not more than twenty miles with a wilth at its mouth of say ten miles will have a tidal rise at its head near twice as great as that at its mouth. So too in larger bays as that of Fundy; a rise of tide of about ten feet at its castern cape becomes an uplift of fifty feet or more at the landward end of the basin. Owing to this 
variation in the amount of tides in different parts of the occan and even on neighboring portions of the same shore the work which they perform is exceedingly variable as regards the measure of the effects, but it is almost everywhere of great importance, and therefore merits careful consideration.

At first sight it might seem that, inasmuch as the tide enters and leaves a harbor with the same volume and velocity in the movements of flow and ebb, the effect of these contrasted motions would neutralize each other. This, however, as we shall see, is not exactly the case. There is always a difference in the effect of the incoming and the outgoing tide which though not great is of momentous importance from its accumulated effects. The nature of this difference is easily apprehended. When the tide enters an inlet it generally flows up an inclined bottom extending from the outer sea to the head of the recess and when it ebbs away it moves down this slope or rather, we should say, out over it. In the movement of the flood the tidal current if it have any consiclerable energy bears a certain amount of detritus up the incline toward the interior of the reëntrant. The distance to which it will be carried will depend upon the energy of this current and the rise of the slope over which it moves. In the reflux the tide will convey the same detritus with the same energy of current, but as it is carrying the débris down a slope it can carry it farther outward than it did inward.

The ordinary action of the ticle, operating in the manner just described, is of itself sufficient to cause its currents to scour away materials from the open shores as well as from harbors and to convey them out to sea to a depth of water where the currents are no longer sufficient to bear them farther. In many if not in most bays and harbors there are 
other conditions which serve to accent in a certain measure this outward setting action which takes place during the period of ebb. Almost all harbors receive a certain share of river water. Owing to the momentum of the tide in entering this water is in a measure banked up; if the discharge from the streams be not large it may all be retained in the basin until the tide turns. This retained water is then permitted to flow out, increasing the energy with which the harbor water goes seaward. The admixture of fresh water, provided it be not heavily charged with mud. probably somewhat increases the capacity of the tide to dissolve and bear along sedimentary materials.

Where, as is often the case, the tide rises higher in the ${ }^{i}$ nterior parts of the harbor than at the mouth, the currents which are generally in proportion to the altitude of the rise weaken as they pass toward the entrance of the inlet. The effect of this action is unfortunate, for the stronger currents near the head of the harbor are likely to stir up and transport toward its mouth more or heavier sediment than the weaker streams. In this way the ticlal currents are apt to coöperate with other agents in producing something like a bar oft the mouth of the port. On the other hand if the harbor have considerable area and depth of water and the tidal rise and fall is great the outrush is certain to keep a channel open for a distance sufficient to cross the zone of migrating sancls which borders the shore. The ticlal channel does not usually arrest the movement of the coastwise journeying detritus. The effect of the migrating sands is generally to push the ticlal scourvay against the side of the bay toward which the dibris is journeying until after a time it breaks a fresh opening through the partial barrier. Where, as in the principal 
entrance to New York harbor, the direction of motion of the coastal sands is not very definitely determined, the course followed by the tide may be pretty steadily maintained for many years. On the other hand, as on the inlets to the lagoons of the Florida coast, where the march of the sands is tolerably constant, the effect of their movement in altering the position of the troughs in which tidal rivers flow is often readily observable from year to year. Even a single great storm may bring about very great changes in the position of these channels.

One of the most interesting features connected with tidal action in the embayed portions of our coast is found in the tendency of the waters when moved by the tidal impulse to organize the flow into regular though sometimes ramifying channels. Rarely if ever do we find the movement diffused as a broad, even sheet over the surface of the embayment; the flow is along lines determined by accidents, often too slicrht to escape apprehension. Distinct, more or less sinuous and rather sharp, walled ways are carved, through which the body of the tide passes in flooding and ebbing, and from which and to which the waters move from the higher lying mud flats or marine marshes on eithes side of the streams. If there be any considerable rivers falling into the liarbor a tidal channel commonly extends to the mouth of each stream. These are usually much the deepest and widest, but similar troughs extend into each ramification of the embayment, so that at low tide the basin may appear like a large map of a land river district. It is easy to see how these channels are maintained, though the conditions of their institution are not apparent. They are kept relatively free from sediments by the tide, which, owing to the depth of water, finds less friction 
in them in proportion to the mass of the current than on the shoaler bottom at either side and so the currents flow faster, thus preventing the deposition of sediment during the period of ebb and flow and removing such materials as may have come to rest at high and low tide when the currents cease to act.

Fortunately for the interest of ports which are visited by ticles, the forces which they apply to our harbors are often readily controllable by engineering constructions. By means of jetties it is frequently practicable to direct the run of streams or by concentrating them to increase their energy in such manner that the character of the exits may be improved. It has been found to be an important precaution in the management of harbors to restrict all natural or artificial changes which tend to diminish the rolume of the tidal water that moves through the inlet. This is the case where about the great cities which have developed on the margins of our harbors it is found commercially desirable to fill in a portion of the shallow sea bottom. The harbor authorities properly require that a compensation be made in the way of dredging other portions of the basin so that the total amount of water which mores with each tide may not be diminished. Those ports are fortunate which have a great extent of ticial waters extending inland bejond the points where the ships seck access to the shore, for such an extensive storage insures a strong flow of tide, and consequently open pathways to the sea. Thus in the case of the port of New lork, the Hudson, which is a marine inlet rather than a river, affords a vast storage basin for the water which passes through the harbor mouths.

The effect of ticlal action is much like that brought about 
by rivers where they emerge through deltas to the sea, only in one case the current is continuous in one direction and in the other it flows alternately to and fro. IThere a tide of considerable height enters the mouth of a large river the effects of the two actions are curiously commingled. The most noticeable feature arising from their coöperation is the occasional occurrence at such points of a singular great inrushing wave, called the bore or eagre. The production of this curious phenomenon appears to be due to the fact that the swift current of the river for a time pushes against the incoming tide, causing it to mount until it attains a height sufficient to quickly reverse the direction of the stream, when the resulting wave moves in with such speed, volume. and height as often to produce disastrous effects. Although something of this action is perceptible at the mouths of many rivers which course swiftly through deltas to the sea and there meet tides of great height, they are best shown at the Amazon, the principal mouth of the Ganges, and the Tsientang in China. In the case of the Tsientang the ware is said sometimes to attain the height of thirty feet, and to move up the stream for the distance of eighty miles with the speed of twenty-five miles an hour. Where the bore is well developed the effect of this action is sreatly to scour the channel and the banks of the stream, and, as in the Amazon, to deliver very large amounts of mud to be mored by the currents of the river or those of the tide. It is probable that the peculiar form of the Delta of the Amazon, especially the exceedingly wide river mouth, is due, at least in part, to the intense scouring action which these singular waves produce.

Where the tidal rise and fall is slight, as about the mouth of the Mississippi, the movement in and out of the channel 
of the stream is insignificant, and the only effect excrciserl by the oscillations is found in a somewhat wider distribution of the river detritus after it is discharged into the sca. The tendency of the tides in such a case seems to be on the whole to obliterate the channels which the stream would make across the submerged apron of the delta. The genural tendency of this class of movements is to withdraw from the shore and scatter over the sea bottom all the fine grained detrital materials which are brought into the sea by the streams or contributed to it by the beating of the waves on the coastline. The effect of this long continued action is indicated by the formation on the borders of the continents and some of the greater islands of a broad, submerged platform, which has received the name of the continental shelf.

The effect of organic life on harbors is generally very great. Save where, as in the case of coral reefs, the growth of particular species tends to the institution of barriers which may afford roadsteads or harbors, the influence is almost wholly detrimental, for it leads to the accumulation of sediments and the consequent shoaling of the water of the basin and along the ocean shore to the diminution in the amount of the tide entering each inlet. Along the margins of our great lakes the harborages are less affected than is the case with the havens of the sea-board, for the reason that fresh water sustains a much less abundant life than does the brinc of the oceans. For convenience of presentation, we shall divide the account of this organic work so as to consicler. first, the action which is accomplished by plants, and, next. that which is brought about by animals. It must be said, however, that in most cases the work of these two groups of organisms is, to a great extent, intermingled. 
The part played by regetable life in the organic economy of the seas is quite as important as is its rôle upon the land. In both realms the plants act as mediators between the mineral kingdom and the higher animal life, which exists solely by means of the mineral elements that the vegetation has brought into a state where animals can make it useful in maintaining their functions. In the seas plant life appears to be almost altogether limited to shallow water next the shores, or to superficial parts of the open ocean. Except in the case of the vast growths of gulf weed which exist in the central parts of the north and south Atlantic and Pacific oceans and the abundant diatoms which develop, particularly in high latitudes far from the land, almost all the vegetable life of the ocean grows near the shores in less than a hundred feet of water. The fact is that vegetable life generally demands the light and with few exceptions is not known to develop in marine waters below the level which has some share of the sun's rays. Only one species, the giant kelp of the Pacific, is known to fasten itself to the bottom at depths of two hundred feet or more, and this unique form elevates its fronds to the surface of the water on a marvellously long and strong stalk.

The species of plants the growth of which is favored by salt water belong to two great groups-the alga or seaweeds, that have no true roots or flowers and otherwise possess only a lowly organization, and flowering plants that have adapted themselves in an exceptional way to the conditions which a station in salt water imposes. In general the seaveeds are most common in more open water than harbors afford, and the larger part of their species grow only below low-tide mark. The higher flowering plants which live in the sea water rarely meet with fit conditions for nurture beyond the limits of the 
more or less sheltered inlets; they are indeed characteristically harbor plants. Therefore it is mainly to this group that we must look for the effect of vegetable life on the conditions of havens.

The only group of seaweeds which to any considerable extent affects the history of our embayed waters belongs to the family of rock weeds-forms which dwell in the section between high and low tide. In the colder waters of high latitudes, especially on the rocky, embayed shores of the fiord zone, plants of these species are often exceedingly abundant. Thus along the cliffs which borcler the inlets of the Bay of Fundy, the rocky steeps are usually covered from near high ticle to the lowest level of the water with a singularly thick and massive coating of those plants. When the tide is out in this region of great rise and fall, this vegetation may form an almost continuous sheet over the surface left bare by the receding waters. The immediate influence of this envelope is to a considerable extent favorable to the preservation of the harbors of the districts in which it abounds. The clense and springy nature of the covering somewhat diminishes the efficiency of the blow which the waves strike upon the shore. A yet more important effect is produced by the nonconductive influence of these plants. When in freezing weather the rocks are laid bare, this coating of regetation serves in a more or less perfect way and often very efficiently to prevent the frost's taking effect on the rock to which it is attached. Wherever in the fiord zone we find an area of jointed rocks between high and low tide, unprotected by this vegretable mantle, we can always clearly note how the frost has shattered the stone into fragments, which may readily be tossed about and still further broken up by the waves. At some points on the coast of Maine the effect of this absence of sea- 
weeds is traceable in the extensive deposits of angular dibris ruptured from the cliffs and distributed over the bottom in part by the waves, but in a more considerable measure by the action of ice. In the winter season the water freezing next the shore entangles large quantities of the detrital matter formed in the manner above described and when this shore ice drifts away with the ticle the rocky fragments are likely to fall at some clistance from the margin of the water.

Where a harbor is of moderate depth over all of its area. where the low ticle comes against cliff shores and the bottom is of a rocky nature, we ordinarily perceive little effect upon its conditions arising from marine vegetation. Where, however. the floor of the basin is to a large extent bare at low tide, and especially where mud is formed in consiclerable quantities, we can orclinarily notice the results arising from the growth of saltloving water plants. They are very evident to the eye and may be traced on any well-made charts. As before remarked, the most of this work is done, not by alga, but by the higher flowering species, of which the greater part belong to the families of grasses and sedges. The constructive work, however, which leads to the filling in of the harbor is, at least in the regions north of Cape Hatteras, begun in the depths of the water by the species known commonly as the eelgrass (Zostcra mantima), a flowering plant which has the almost unique characteristic of blossoming, fertilizing its flowers, and fruiting beneath the level of the water. The conspicuous parts of the plant consist of thin blade-like leaves, about a fifth of an inch in diameter, but sometimes eight or ten feet long. Owing to their strength these blades of the eelgrass withstand the impulse of surges, such as act in the protected waters of harbors, and by their thick-set order they diminish or entirely arrest 
the currents of the tides which sweep through their interstices.

When the ticle is high, the tops of the celgrass plants are some feet below the surface. During the period when there is little motion to the water the sediment which may have been brought up into it during the time when it was moving swiftly settles between the stems of the plants and gradually accumulates at their base where it is protected from further disturbance. Many species of animals dwell amid the close-set herbage, finding in those conditions a measure of protection and a good share of food. The remains of these creatures are also con-

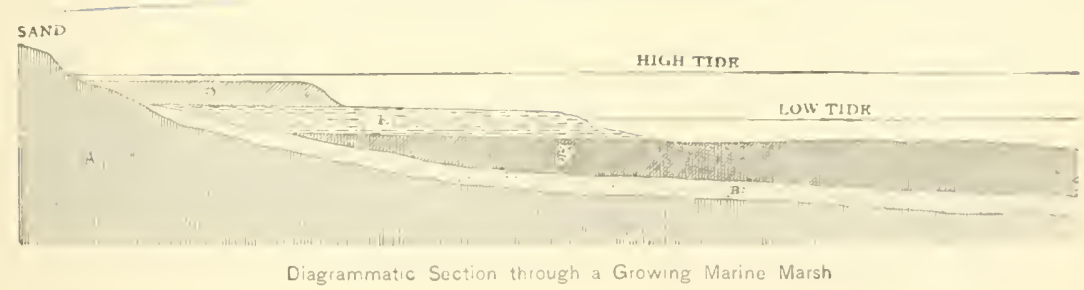

tributed to the growing mass of detritus. In time these accumulations rise to near the level of low tide. In this position the eelgrass will no longer flourish, and for a time the deposit of mud is apt to be left as uncovered ooze. or at most it bears an imperfect coating of algre. At this elevation, however, the detrital matter is protected from the action of the swifter tlowing ticlal streams, for these move with consiclerable energy only in the deeper water channels. The facts observable along our northern harbors clearly show that the eelgrass cloes an extensive work in diminishing the depth of water over large portions of the harbor floors.

While the eelgrass serves to shallow the water of our harbors to near high-tide mark, a number of plants are at work in a different manner around the margins of these water areas. 
Wherever the shore is of an earthy nature at high-tide level a number of species of flowering plants, principally belonging to the grasses, take root a little below high-tide mark, grow luxuriantly, and develop a dense mat of lowly vegetation. The tops of these plants die down each winter, but their roots are perennial and closely interlaced, forming a very dense and elastic tangle, which is well fitted to resist the blows of the waves. In course of time the interwoven living and dead roots form a mass, having a thickness of from one to two feet. Its upper surface is always so placed as to be covered by each high tide, except perhaps on a few days in the year. In most cases the water rises high enough to cover all but the tops of the full grown stems. When the tide is low the whole of these marine marshes is laid bare; generally, indeed, they do not extend below the level of half tide.

In the process of its growth the mass of marine marsh pushes horizontally outward toward the mud flats. The margin of the accumulation is commonly somewhat undermined by the action of the waves, so that it falls as a sloping curtain, and in a measure protects the bank from such surges as may form in a tolerably well sheltered basin. From time to time the waves and ice break off masses from the low cliff which borders the mud flat. This debris is commonly distributed over the bottom next the growing marsh and helps to shallow the water to the point where the grasses can take root. In this manner the growth is extended over the deposits of ooze, it may be for a distance of miles. The limitation in the spread of the marsh is effected in some cases by the fact that the margin comes into a position where the waves break it up, but more commonly the restriction is brought about by the action of the tide in keeping open channels by 
which the water enters and leaves the area occupied by the marine marshes.

As ordinary tides cover salt meadows to the depth of a foot or more it is evident that if the area of these fields be extensive the quantity of water which enters upon and departs from them twice each day may be large in amount. The movements of this flux and reflux are in a spontaneous way accurately organized. Looking over an extencled field of marine marsh when the tide is low we observe a system of channels in areal extent proportionate to the surface occupied by the water at high tide, the whole appearing, as before remarked, like a condensed map of a great river system. At many points on the marsh, rarcly separated by more than a few hundred feet, we note shallow drainways, often from ten to twenty feet wide and only a foot or two deep. Close observation will show that the greneral surface of the area about these troughs slopes with a very gentle inclination toward their margins. Following the water in the ebbing tide we note that it drains into these grooves which, as they extend, become deeper and with more distinct banks, the natural result of the additional energy of the stream occupying it. One of these grooves coalesces with another, the united channels become deeper, until, in a distance of a mile, the gathered waters are strong enough to cut a channel extending to below low-tide mark. If a number of these permanent waterways unite they may form a broader tidal river.

Where the process of development of a marsh growth in a harbor basin is complete, the whole of its area which is not required for the ingress and egress of the tide is occupied by the mat of vegetation or by the decayed vegetable matter that forms beneath it. In this condition the marshes can no longer extend themselves either in a vertical or horizontal 


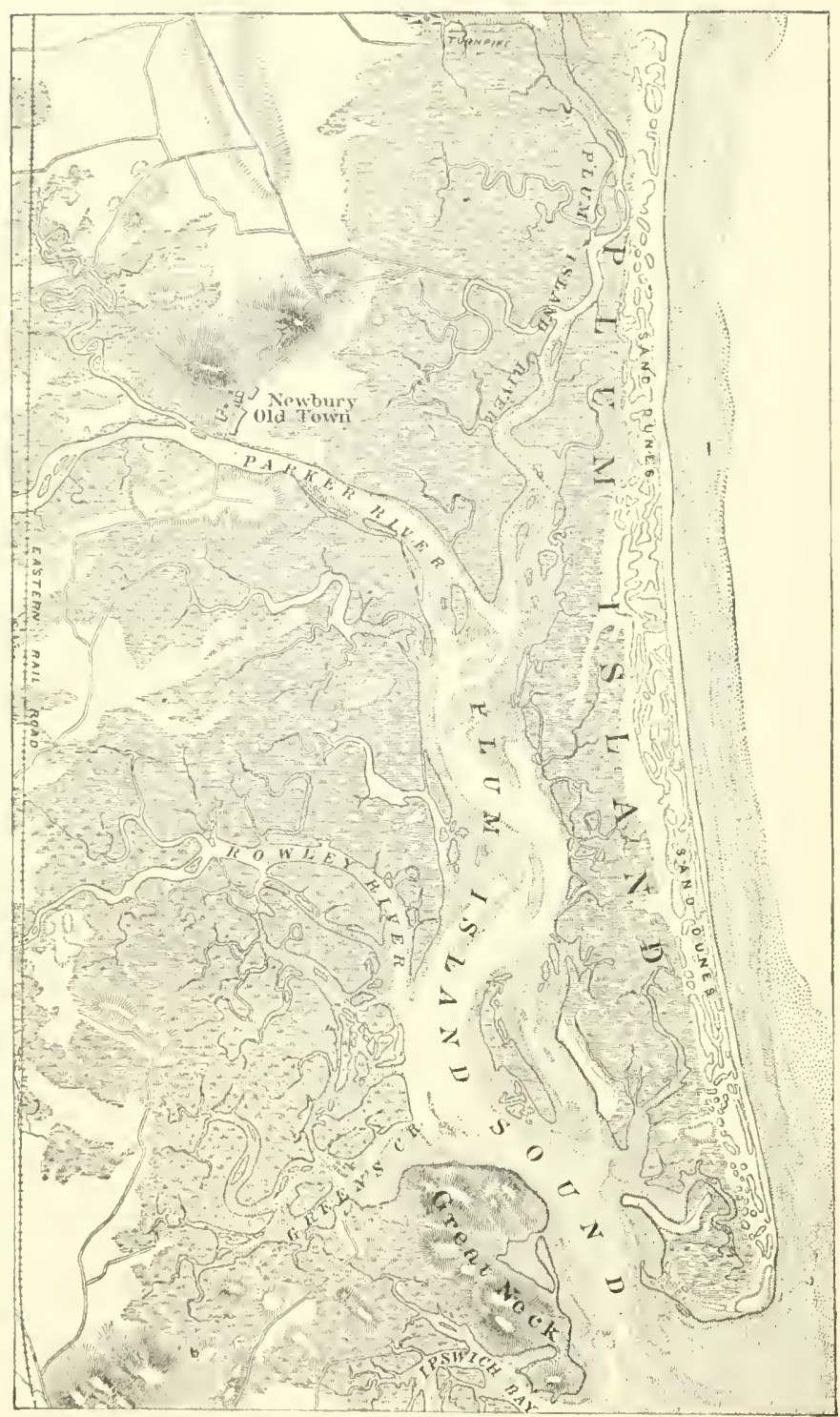

Plum Island Marshes near Newburyport, Massachusetts

direction. They cannot grow upward for the reason that the species which live upon them require to be flooded with salt water cach day for a certain number of hours. When this 
altitude is attained, the growth of the plants becomes retarded; the species of animals which aid in the formation of the marsh deposits cease to live in the locality and the rate of decay of the vegetable matter is sufficiently rapid to balance the deposition which growth brings about. The fict that the marshes cannot attain to the level of high tide is of momentous consequence to the condition of our harbors, for the reason that it insures a permanent and consiclerable flow of water through the remaining tidal channels. But for this limitation many of our harbors which have attained to the state where the marshes can no longer develop would already have been closed.

The marginal growth of the marshes when the development of the field is near maturity comes to a point where the efforts of the vegetation to win new ground are successfully opposed by the flow of the tide that is made more energetic by the extent to which it is confined within narrow limits through the growth that has fenced it in. When the development is complete there is no mud bank left for the roots to extend over; the slope toward the stream descends steeply into tolerably: deep water which often affords an excellent haven for ships. So far as possible the growth of the marsh plants and the formation of their dense mat of root fibers deepen the tidal stream by narrowing the horizontal distance between the banks. In fact, the ultimate conditions of the area are not completely attained until the principal creeks have been forced to excavate their beds to a depth below that which they had hefore the shelf of the marsh began to press upon the streams. Hence it comes about that in most cases the depth of water in their channels is considerably greater than in the part of their path which lies beyond the limits of the grassed fields. 
The way in which the growth of these marshes is effected varies somewhat, so far as details are concerned, according to the peculiarities of their site. The carbonaceous matter which forms a large part of the fibrous layer is taken from the atmosphere and by the process of decay gradually returns to it. The permanent accumulations of the marsh are contributed in part by the mud which is stirred into the sea water by the incoming tide as it rubs upon the bottom and is then distributed among the grass stems where it settles cluring the time when the motion of the water is arrested, as it is for an hour or two when the level is highest. This mud is effectively confined amid the vegetation and adds to the mass of the marsh shelf. Another element of increase is found in the development of shell-bearing animals, principally mollusks and crustaceans, which find a suitable site for their development amid the dense herbage. At their leath these creatures leave their shells to be built into the growing deposit.

Narine marshes of the nature above described can in most cases readily be won to agriculture and afford lands of extraordinary fertility. Unfortunately, however, the means whereby they may be so brought under tillage are necessarily prejudicial to the conditions of the harbors where they lie. In their natural state they afford only light crops of poor hay. To fit them for other use it is necessary to bar out the sea waters, an action which necessarily diminishes the energy and consequent scouring power of the tidal streams. A good instance of this effect is shown by an experiment made ten years ago on a tract of about fifteen hundred acres of marsh in the county of Plymouth, Massachusetts. On the seaward border of this area there was a small harbor which was useful to fishing vessels and other craft drawing not more than six feet of water. When, how- 
ever, a dike was constructed which debarred the ticle from the area it had visited the haven was rapidly shoaled by the incursion of sands and became almost worthless for the shelter of such craft as had previously resorted to it. On this account it will be necessary carefully to consicler the effect of all operations looking to the reclamation of tidal marshes.

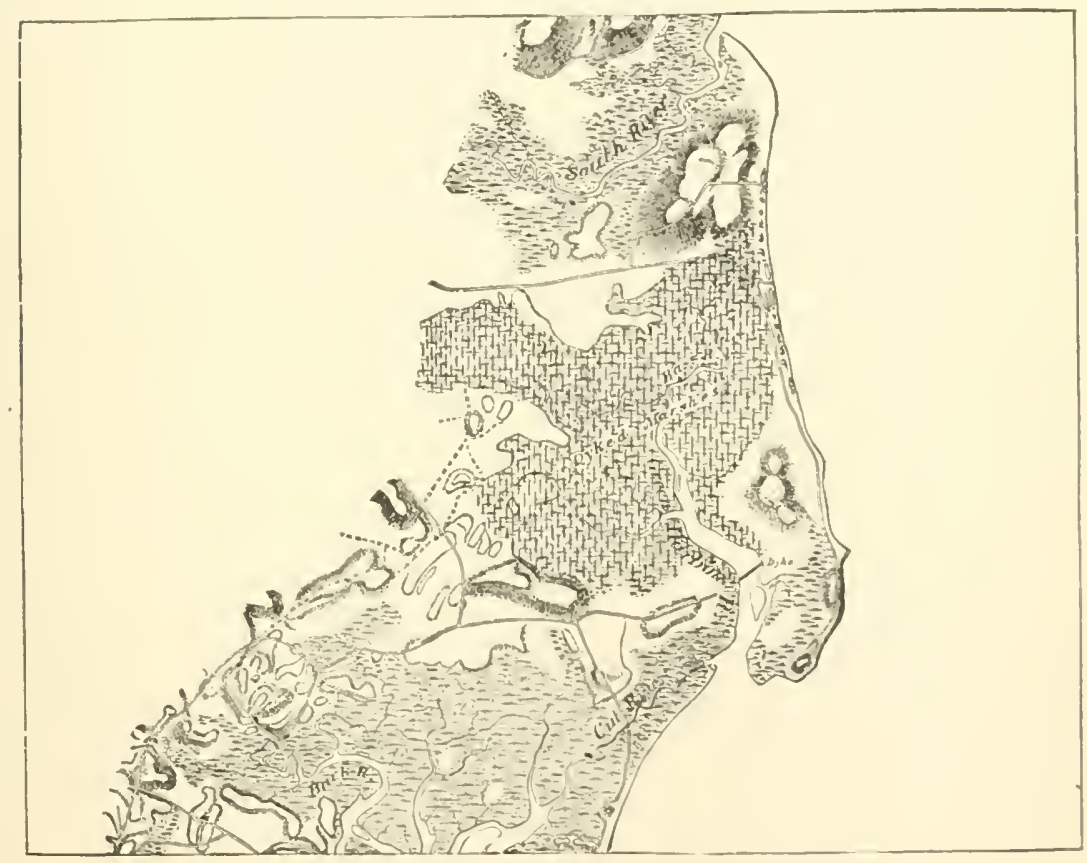

Dike and Marshes, Green Harbor River, Marshfield, Massachuse:ts

It is a very general fact that in high latitudes, usually in all districts to the north and south of the tropical realm, regetation of the marine marshes consists altogether of plants which have only annual tops, though their roots may endure for years. No bushes or trees will grow on these marshes so long as they are visited by the tide. In the warmer districts, within or near the tropics, we find certain species of trees which have become reconciled to the peculiar conditions imposed by having their 
roots in salt water and which have indeed developed a variety of remarkable structures favoring their life in such positions. These species are commonly known by the name of mangroves. Of the many thousand species of trees there are probably less than a dozen which have effected this curious adaptation enabling them to dwell on lands below high-tide mark. Though these forms are few, there being but two species known in this country, the part which they play in the history of the harbors in the warmer parts of the continent is most important. The work which they do in modifying the inclosed marine waters is even greater than that effected by the salt-loving grasses which flourish in colder climes. It will therefore be well for us to trace, somewhat in detail, the way in which the mangrove attains its peculiar development.

The seed of the mangrove is remarkably large and is a slender cylinder, tapering at either end and about six or eight inches in length. The lower extremity is armed with a number of small hooklets, and is so weighted that when the seed falls into the water, as it normally does when it parts from the parent stem, it floats beneath the surface in a nearly rertical position. As it absorbs water it settles near the bottom, so that when driven around by the currents it is likely to become attached to a bit of seaweed or other object lying on the floor of the harbor. Thus fixed it quickly' takes root and sends its shoot towards the surface of the water. If that surface be only a foot or so away at low tide it may manage to obtain access to the air, subsisting the while on the considerable store of nutriment contained in the relatively large seed. Rising above the surface of the sea, it soon develops its first leaves and establishes the crown or point between the roots and stem at about high-water mark. Above this level the trunk and foliage much resemble the India- 
rubber tree, or Indian fig, which is a familiar object in greenhouses. The branches, however, have a widespreading, rather low habit, and from them as well as from the crown of the tree there grow off long, runner-like processes which extend for a distance of some feet in a horizontal direction, and then curving sharply downward descend through the water until they attain the bottom, where they take root. These curious processes, though at first slender, gradually increase in size and become strong supports, from which new crowns, with their trunks and branches, may spring. 'Thus a single tree may rapidly march away from the original planting-point until its outer verge may be an indefinite distance from its place of origin.

Underneath the close-set crowns of the mangrove the roots make a dense tangle, where a host of marine animals harbor and contribute their dibris, in the way of sediments, to the bottom. At the same time the tidal waters, having their current arrested by the obstructions which they encounter in the submarine part of the forest, deposit quantities of mud. These accumulations, mingled with the leares and branches which fall from above, serve rapiclly to shoal the water until marshes take the place of fields which were before inundated even at low tide. When this state in the growth of a mangrove plantation is attained, the species which have won their way against the sea gradually die out and their place is taken by others which, though they can not live in contact with salt water, can flourish on the marshy accumulation formed by their predecessors.

Owing to the vigor of growth of the mangrove trees and to the peculiar roots which they put forth, they can withstand the assaults of much heavier waves than the frailer marsh plants of higher latitudes. The mangroves of southeastern Florida 
march in such a sturdy way against the sea that they can resist waves which occasionally attain the height of four or five feet. Much of the Everglade district has been won from the condition of shallow water to the state of swamp by their action during relatively modern times. Their rate of advance over the shallows is much more rapid than that of the grasses which form the northern marine marshes, and is limited only by water which is too deep for their root-like runners to descend through it and fix themselves upon the bottom. Where the water which they seek to penetrate is tolerably deep, their growing ends are apt to be swayed by the current so that they can not readily attain a foothold. Moreover, they are more or less eaten by certain fishes which have a fancy for vegetable food.

In regions which are sufficiently warm to permit the free development of mangroves, they take possession of all the mud flats which in more northern districts would be occupied by grass marshes. The result is that margins of the harbors have a totally different aspect from that which is presented by the shores of the havens in higher latitudes. Their general effect, however, is the same as that which is brought about by the lower growing plants which dwell between high and low water mark. They narrow the channels of the reëntrants, and by concentrating the tidal flow into a small space serve somewhat to increase the scouring action of the currents through the acceleration of their velocity which is thus induced. Owing, however, to the fact that the mangroves elevate the marshes somewhat above the level of high tides, these trees by debarring the tidal water from entrance to extensive districts are on the whole more deterimental to havens than are the grassy marsh growths. The last named type of vegetation 
never extends to high-tide mark, but always leaves a foot or two in depth above the surface to be filled by the water at high tide. The result is that the tidal channels in the mangrove district are relatively much shallower than those beyond the field.*

In discussing the influence of vegetation on harbors we have already had occasion, incidentally, to refer to the action of certain forms of animals which dwell amid salt-loving plants and contribute their remains to the marshy accumulations. We have now to extend our consideration of the work done by the various shell-bearing animals to those parts of harborages where they dwell apart from vegetation. Wherever an inlet of the sea is the seat of a considerable tidal flow we are sure to find that the conditions favor the abundant development of animal life. Along the shores of the sea, near the mouth of the reäntrant, the waves are continuously at work beating the remains of marine animals and plants into a finely divided state, where they readily float in the water and afford large amounts of nourishment to the living beings with which they come in contact. A host of species dwell in this water and draw their sustenance from it. With each oscillation of the sea the food-giving fluid is swept past the multitudinous mouths of the animals which dwell on the floor of the harbor, and which thus at once obtain the shelter of its recesses and a supply of nutriment fitted to their nurture.

The most important sediment-producing animals of havens are found in the group of mollusks. The most of the species in this type are shell-bearing. They grow rapidly, and at death a large part of their bodies is contributed to the sedi-

* For further information concerning mangrove marshes, see Tenth Annual Report of the United States Geoloyical Survey. 
ments. There is a very great diversity in the mode of life adopted by these molluscan species. The most of the univalves are unattached to the bottom, and are apt to be swept about by the tidal currents where the movements are particularly strong. The bivalve shells which are prevailingly larger and make more consiclerable accumulations of detritus are usually fixed to the bottom or dwell in the mud, in which they excavate chambers large enough to give shelter to their boclies. Some species which lie upon the floor of shallow water are not attached, and at their death their shelly coverings are often washed ashore. In some cases the accumulation made along the margin of the harbor is sufficient in quantity to lead to the formation of a shelf, which gradually extends toward the deeper water. Generally, if not always, this accumulation of shells is more or less associated with vegetable matter formed by the marine marsh plants.

By far the most important of our mollusks in the work of accumulating sediments in harbors is the common oyster, which exists in the form of numerous ill-determined species along the greater part of the shores in the temperate and warm portions of the world. The most of the varieties of this interesting animal have become especially adapted to life in brackish water, such as our harbors afford. In general they require a mixture of from one-fourth to three-fourths of water from the land with that from the sea to afford conditions for their fullest development. Where these conditions are combined with shallow water the oysters may grow rapidly, their shells forming an almost continuous sheet over wide areas, the living lying upon the dead in a deposit many feet in thickness. In the northern part of the field which they occupy-as, for instance, between New York and Newfoundland, where the situations 
are least favorable for their growth-these mollusks are rarely very efficient agents in shallowing the water; yet, even about Boston, Massachusetts, certain of the estuaries, particularly the part of the Charles River known as the Back Bay, has some hundreds of acres of its area occupied to the depth of several feet by the shells of this species. For many years the living forms have disappeared from these waters, but it is evident that a considerable part of the accumulations which have served in good part to close the original entrance of Boston Harbor are composed of their remains.

South of New York the importance of the oyster in the history of the harbors steadily increases until we attain the coast of Florida. In its maximum development from near the mouth of the Savannah River to Jupiter Inlet the larger part of the shallow bottom inside of the ocean beach is occupied by beck of these shells. So crowded are these forms that they push their growth above the level of low-tide mark and in the region where the mangroves abound they cluster on the roots of the trees in such numbers as often to hide them from view. The waves break off great quantities of shells and toss them upon the beach which borders the widespread marine marshes of this district, the so-called savannas of our southern coast. In this position the díbris is rapidly covered by the swiftly extending vegetable growth. Between Charleston, South Carolina, and Biscayne Bay, Florida, there is an aggregate area of nearly a thousand square miles which, when the shore assumed its present elevation, was occupied by tolerably. deep water that has now become filled to near the level of high tide by sediments composed in large part of oyster shells. The singularly rapid growth of these savannas as compared with the marine marshes on the more northern parts of our 
shore is largely to be explained by the great and swiftly accumulated deposits of such shells which are formed in the southern clistrict.

In proportion as we go southward the share of vegetable matter which is built into the marine marshes rapidly diminishes until in the Georgia district, although the species of the salt-loving grasses and rushes, as well as other plants, are more numerous and, as regards growth, more vigorous than in the northern districts, the contribution which they make in the way of sediments is inconsiderable. The reason for this is easily seen. Owing to the greater warmth of the southern realm the process of decay of the clead vegetation is much more rapid and complete than in the north. On the other hand, the warmth of the water in the southern field favors the rapid development of shell-bearing animals, particularly of the oysters, which contribute vast amounts of debris to the growth of the marsh deposits. The result is that the southern growths of this nature are formed with far greater rapidity than those of the northern realm. Along the greater part of the coast south of Charleston the development of these organic benches has attained the point where their further extension is arrested on account of the energy of the ticlal movement. In fact the conditions have come to the balanced state, which, as we have seen, is the natural result of the struggle between the organic actions which tend to construct marine marshes and the physical forces which contend against their growth.

There are many other marine animals which here and there in varying quantities form organic sediments which lead to the shallowing of harbors. Of these we can only incidentally note a few of the more important. The conmon 
clam (Mya "ronaria Linn.) is in northern regions a species which adds rapidly to the growth of the mud banks so commonly lying between the margins of the marine marsh shelf and the edge of the deeper tidal streams. This species has the habit of abiding beneath the surface of the mud, holding communication with the water by means of its long protrudable siphon. Owing to its curious habit of life the shells of this species are not visible on the mud flats, and are not often washed ashore, and thus the important work performed by this creature in shoaling the water, a work in which it is only less important than the oyster, is apt to be unnoticed by the casual observer. The Pectens or scallops also play an important role in sedimentation, but the fields on which they grow are much more limited than those of the species above mentioned. Owing to the lightness of their shells they are more commonly swept against the harbor beaches than any other species, except some of the tropical kinds.

Besides mollusks there are numerous other animals which make important contributions to the detritus accumulating in our harbors. Of these the crustaceans are the most noteworthy. The crabs, lobsters, and their lower kindred, the shrimps and sand hoppers, grow rapidly, exist in great numbers, and at their death leave tolerably solid skeletons as contributions to the growing sheet of sediment. Much of the exceeding fertility which characterizes all marine marsh lands won to tillage is due to the phosphate of lime which exists in the shells of these creatures whose forms have been buried in the deposit. A group of lowly organisms known as Foraminifera affords a host of small and swift crrowing forms which secrete hard sheletons, mostly of limy matter. 
These species abound in many harbors which are visited by warm waters, and often bring about the formation of a lime ooze composed of such finely divided matter that the material is readily swept about by the tidal currents. Deposits formed of the remains of these creatures abound in the regions of coral reefs. In such reef-bordered shores the species of coral which dwell within the lagoon are very effective agents in shoaling the waters which they inhabit. This result is, however, combined with that which is effected by a host of other organic forms.

Before taking leave of the interesting phenomena exhibited by the organic deposits of the coast-lines it is well to consider them in a somewhat more general manner than we have hitherto done. In the first place we should notice that the amount of these contributions made to the sea-floor and the importance which they have to the life of man are alike singularly great. Although the ocean bottom is almost everywhere receiving contributions of organic sediment, the quantity of this material which is laid down next the shore is far greater than that deposited beneath the deeper seas. The reasons for this accentuation of the coastal deposits which are laid down by animals and plants is easily perceived. It is due in part to the large quantities of material fitted to be the food of animals and plants which is conveyed from the land to the sea by streams of fresh water. In part it is contributed by the action of the waves, which are constantly at work grinding up organic and inorganic material and diffusing it in a way to serve the needs of living beings. Still farther along the shallows next the shore the light of the sun penetrates through the water to the bottom and there stimulates the growth of a host of species 
which develop far more rapidly than is possible with organisms abiding in the midnight darkness which exists in deeper parts of the sea.

Owing to their novelty and in a measure to their singular features the coral reefs have appealed to the imagrinations of observers and have received a share of attention and interest which is much out of proportion to their real value among our coastal accumulations. The less noticed because more familiar cleposits, such as are contained in our marine marshes, are not only on the whole more important, but are in their way as beautiful, and from a scientific point, as noteworthy as the barrier reefs and atolls which here and there occur within and near the tropical realm. To the thoughtful observer the marine marshes of New England or Georgia afford by the variety and beauty of their phenomena even more interesting structures than any which the zoöphytes build. The part they play in relation to the interests of man is much more important than that which is performed by the reefbuilding animals. In their aspect they are much more interesting than the constructions due to the polyps. There is nothing in the coral islands to compare with the brilliancy of coloring which the marshes of New England exhibit at certain seasons of the year; nothing like the varicty of hue which characterizes these prairies by the sea in the different seasons, and which makes it possible for the naturalist to trace the changes in their aspect month by month through the annual cycle. None of the elements of form of the coral reefs approach in beauty those afforded by the marine marshes. The growing portion of the reef is almost altogether hidden from the eye; all that is evident consists of ruins tossed up by the waves or elevated with the uprisings of the shore but 
in all the stages of water below mid tide the marshes present a beautiful plain of vegetation the tints of which vary from month to month and even from hour to hour as they receive or discharge their waters. Nothing in the geographic world is more graceful than the curves of the creeks through which the tidal waters enter and depart in their constant movement.

The variety in the character of the marine marshes which is brought about by the slight changes in the amplitude of the tidal swing and other variations in the conditions of the shore is singularly great and is unparalleled in the physiognomy of coral reefs. Thus for each hundred miles of distance along the Atlantic coast from the Straits of Belle Isle to Key West the aspect of the mud flats and grass-covered plains so constantly varies that anyone who was well acquainted with their peculiarities could tell pretty nearly whereabouts he had landed on the shore by the appearance of these fields. All organic life is beautifully and variedly adjusted to the conctitions of its environment, but it is doubtful if in any other zone of the organic world the accommodations are more exquisitely ordered than in the marshes of the ocean shore.

It is otherwise with the harborages of our fresh water lakes. In those tideless waters the action of organic life is practically limited to the growth of certain rushes and sedges which spring from the bottom of shallow water and gradually accumulate a deposit of ordinary peat such as is so generally formed in our fresh water bogs. In many cases, as, for instance, about the Great Lakes of the Northwest, this accumulation of decayed vergetable matter goes so far as to close a large part, if not the whole, of many havens, even those which were originally extensive in area. We fail, however, to find in these situa- 
tions any plants so well adjusted to the work of winning the ground from the sea as are those which dwell along the seaboard. This lack of variety in the water-loving vegretation, together with the relative absence of acquatic animal life and the non-existence of the tides, makes these fresh water accumulations of comparatively little interest except that which is due to the fact that they injure or destroy a large part of the shallow harbors of our navigable lakes. IVe shall therefore dismiss them without further consideration and close our general account of the organic influences which affect harbors with a brief résumé of the facts, as follows, viz.:

First, the land plants which have become reconciled to living in salt water are the principal organic agents in effecting injurious changes in harbors. Their influence on the whole seems greater than exercised by any other single agent.

Second, the greater part of this work is done by the plants belonging to the kindred of the grasses.

Third, the efficiency of the work is clue in large measure to the coöperative effect of the tides, which nourishes the vegretation and the animal life which dwells amongst it.

Fourth, the effect of the tide-water grasses is to diminish the area of harbors and usually to deepen the creeks which remain. The effect of mangrove growth is to occlude the harbor by altogether cutting out the storage of water at high tide.

Fifth, the effect of animal life other than that associated with the marine grasses is purely destructive to the interests of harbors, serving to shoal the water throughout the basin.

Sixth, all the organic deposits next the land-coral reefs, mangrove and grass marshes - are to be regaded as belonging in one great group of coastal accumulations, of which the 
divisions including the formations built up by plants are of much more general importance than those which owe their origin to the growth of polyps.

Seventh, the greater portion of the embayed waters of the ocean shore have been closed by organic action during the last geologic period. 


INIVIRSITY OF CALIFORNIA LIBRARY

Los Angeles

RECEIVYe DUE on the last date stamped below.

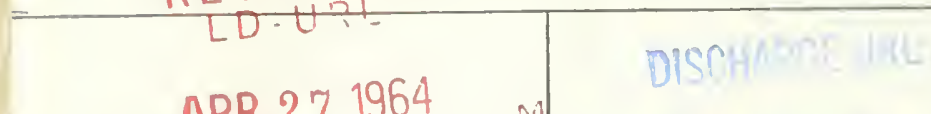

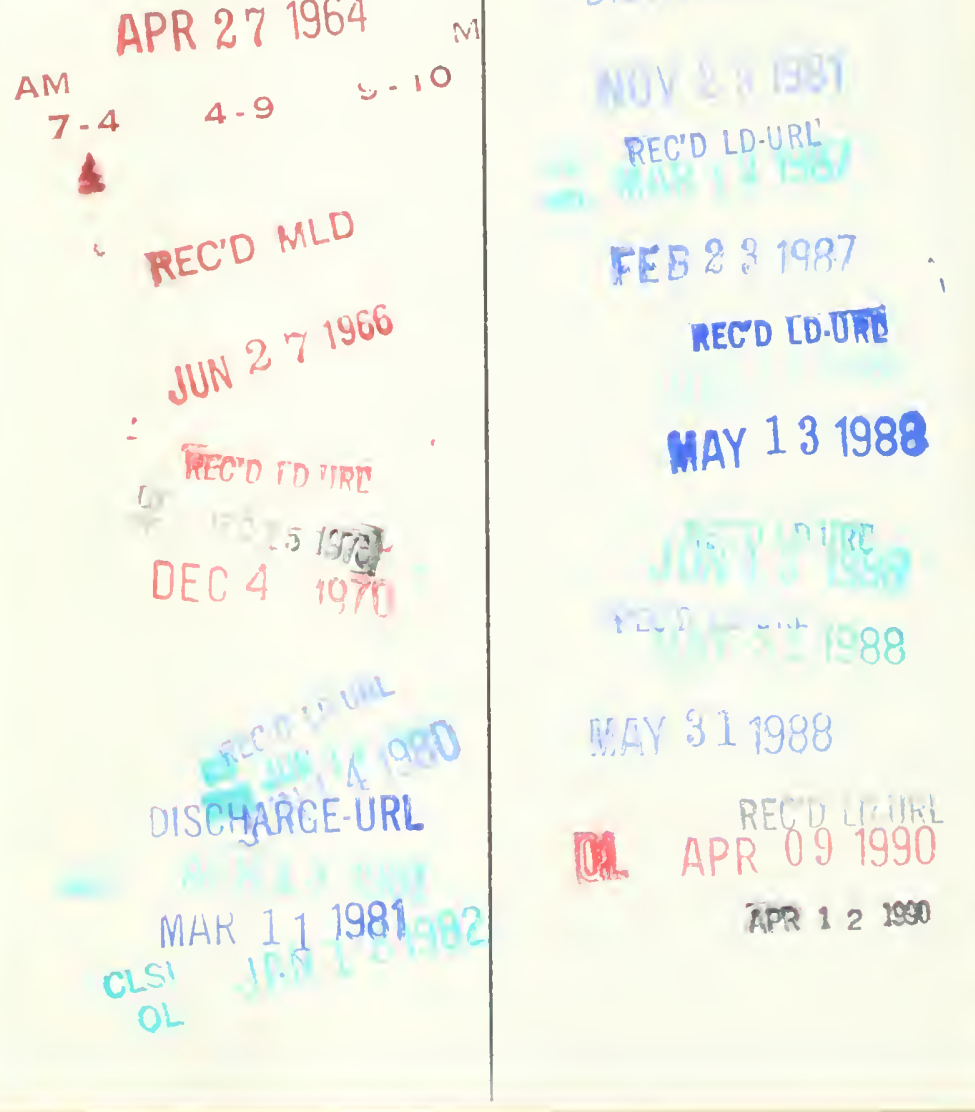


UC SOUTHERN REGIONAL LIBRARY FACILTH 
